\title{
Alaska's Mineral Industry 2014
}

Special Report 70
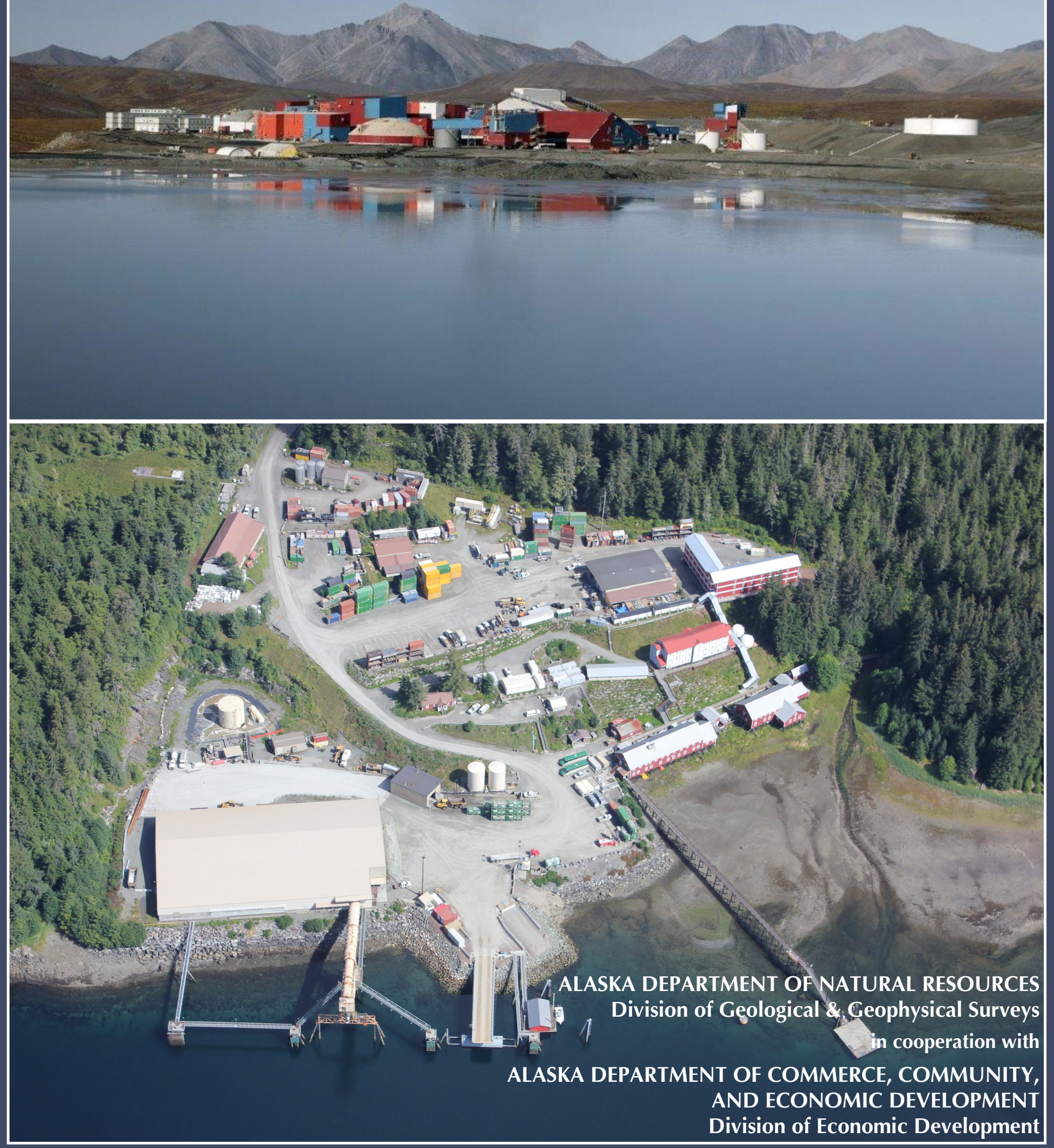


\section{Alaska's Mineral Industry 2014}

\section{Special Report 70}

by

L.K. Freeman, J.E. Athey, P.S. Lasley, and E.J. Van Oss

DEPARTMENT OF NATURAL RESOURCES

Division of Geological \& Geophysical Surveys

in cooperation with

\section{DEPARTMENT OF COMMERCE, COMMUNITY, AND ECONOMIC DEVELOPMENT Division of Economic Development}

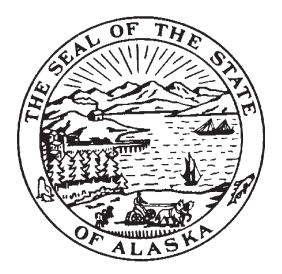

Front Cover U pper: Photo of the Red Dog Mine mill complex, in the western Brooks Range northwest of Kotzebue, Alaska. The tailings storage facility is in the foreground and the DeLong Mountains are the background. The Red Dog zinc-lead-silver mine celebrated 25 years of continuous operation in 2014. The mine is operated by Teck Alaska Inc. under a lease agreement with NANA Regional Corp. Photo courtesy of Teck Alaska Inc.

Front Cover Lower: Photo of the Greens Creek Mine port facilities on Hawk Inlet, Admiralty Island, southeastern Alaska. In 2014 the silver-lead-zinc-gold mine, operated by Hecla Greens Creek Mining Co. celebrated the 25th anniversary of its initial production; except for a brief closure from 1993 to 1996 the mine has been in continuous operation since 1989. Photo provided by Hecla Greens Creek Mining Co.

Back Cover: 2014 marks the 25th anniversary of the start of production at Red Dog and Greens Creek mines. The photos on the front and back cover of this report feature historical and contemporary photographs of both mines. For more information on Red Dog Mine, please see page 39; for Greens Creek see page 48.

Back U pper Left: Underground truck back-hauling mill tailings into Greens Creek Mine. Greens Creek places half of its tailings, mixed with cement, in underground production voids. "Backfilling" stabilizes the mine walls, allowing for safe, maximum extraction of ore, and reduces the need for surface tailings storage. Photo provided by Hecla Greens Creek Mining Co.

Back Lower Left: Sulfide flotation froth at the Red Dog mill. Reagents in a pulverized ore slurry produce bubbles in agitator tanks; the bubbles selectively float finely ground ore particles. The froth and the ore particles are scraped off the top of the tank, filtered, dried, and shipped to an off-site smelter. Both Red Dog and Greens Creek mines ship concentrates from purpose-built marine loading facilities at saltwater. Photo provided by Teck Alaska Inc.

Back U pper Right: The "Big Sore" Greens Creek discovery outcrop. Company geologists discovered this outcrop of the Greens Creek massive sulfide deposit in 1974 while conducting a regional reconnaissance geochemical survey. Photo from U.S. Geological Survey Professional Paper 1763, "Geology, geochemistry, and genesis of the Greens Creek massive sulfide deposit, Admiralty Island, southeastern Alaska."

Back Middle Right: Dialog between Cominco American and NANA Regional Corp. representatives led to the innovative operating agreement between the international mining company and the Alaska Native corporation in 1982. The agreement has been the foundation for 25 years of production and regional economic opportunity while protecting the environment and traditional subsistence lifestyle. Photo provided by Teck Alaska Inc.

Back Lower Right: Installing rock bolts at Greens Creek Mine. Miners drive tunnels $15 \mathrm{ft}$ high by $15 \mathrm{ft}$ wide to access the various ore zones to be mined; rock bolts are used as one of several methods to ensure that the tunnels stay intact and miners can work safely as the tunnels are advanced. Photo provided by Hecla Greens Creek Mining Co. 


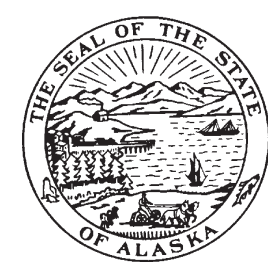

STATE OF ALASKA

Bill Walker, Governor

\title{
DEPARTMENT OF NATURAL RESOURCES
} Mark Myers, Ph.D., Commissioner

\author{
Division of Geological \& Geophysical Surveys \\ Steve Masterman, State Geologist and Director
}

\section{DEPARTMENT OF COMMERCE, COMMUNITY, AND ECONOMIC DEVELOPMENT Chris Hladick, Commissioner}

\author{
Division of Economic Development \\ Britteny Cioni-Haywood, Director
}

Publications produced by the Division of Geological \& Geophysical Surveys (DGGS) are available for free download from the DGGS website (www.dggs.alaska.gov). Publications on hard-copy or digital media can be examined or purchased in the Fairbanks office:

\section{Alaska Division of Geological \& Geophysical Surveys \\ 3354 College Rd., Fairbanks, Alaska 99709-3707 \\ Phone: (907) 451-5010 Fax (907) 451-5050 \\ dggspubs@alaska.gov \\ www.dggs.alaska.gov}

\begin{abstract}
Alaska State Library
State Office Building, 8th Floor

333 Willoughby Avenue

Juneau, Alaska 99811-0571

Elmer E. Rasmuson Library

University of Alaska Fairbanks

Fairbanks, Alaska 99775-1005
\end{abstract}

\author{
Alaska Resource Library \& Information \\ Services (ARLIS) \\ 3150 C Street, Suite 100 \\ Anchorage, Alaska 99503 \\ University of Alaska Anchorage Library \\ 3211 Providence Drive \\ Anchorage, Alaska 99508
}

This publication, released by the Division of Geological \& Geophysical Surveys (DGGS), was produced and printed in Anchorage, Alaska, by A.T. Publishing, Inc., at a cost of $\$ 5.15$ per copy. Authority to print this and other publications comes from Alaska Statute 41.08 .020 , which charges DGGS to "...determine the potential of Alaskan land for production of metals, minerals, fuels, and geothermal resources; the location and supplies of groundwater and construction materials; the potential geologic hazards to buildings, roads, bridges, and other installations and structures; and... conduct such other surveys and investigations as will advance knowledge of the geology of Alaska." Statute 41.08 .030 adds, "The state geologist shall print and publish an annual report and such other special and topical reports and maps as may be desirable for the benefit of the state...." In addition, Alaska Statute 27.05.050-060 states, "The department shall conduct a continuing survey of the mineral resources and mining operations of the state and shall disseminate information regarding them to assist prospectors and miners, safeguard the lives and health of miners, protect investors in the mining industry, and foster and promote the best interests of the mining, mineral, and related industries of the state... The department shall make an annual report to the governor on all essential matters with regard to mining in the state..."

The State of Alaska Division of Geological \& Geophysical Surveys complies with title Il of the Americans with Disabilities Act of 1990 . This publication is available in alternative communication formats upon request. Please contact DGGS (phone 907-451-5010; fax 907-451-5050; email dggspubs@ alaska.gov) to make any necessary arrangements.

NOTE: Mention of any company or brand name does not constitute endorsement by any branch or employee of the State of Alaska. 


\section{EXECUTIVE SUMMARY}

Alaska's Mineral Industry 2014 is the 34th annual report produced by the Division of Geological \& Geophysical Surveys (of the Department of Natural Resources) and the Division of Economic Development (of the Department of Commerce, Community, and Economic Development). Published for more than one-third of a century in this format, the annual report endeavors to provide a consistent, factual snapshot of mineral industry activity in Alaska and also serves as the authoritative, historical record of mining in the state.

\section{BY THE NUMBERS ...}

Exploration $\Downarrow 45+$ percent, to $\$ 96.2$ million

Development $\Downarrow 21+$ percent, to $\$ 281.7$ million

Production $\Downarrow 4$ percent, to $\$ 3.28$ billion

Total Industry Value $\quad \Downarrow 7+$ percent, to $\$ 3.66$ billion

\section{ALASKA'S MINERAL INDUSTRY 2014}

$\Rightarrow$ The total reported value of Alaska's mineral industry decreased in 2014 to $\$ 3.66$ billion, more than 7 percent lower than its $\$ 3.95$ billion value in 2013 . The total value is a composite of the year's expenditures on exploration and development plus the estimated first market value of the commodities produced. Alaska's mineral production sector remained strong despite slowdowns in exploration and development spending.

$\Rightarrow$ Zinc was the top metal produced in 2014, according to its production value of almost 44 percent of total Alaska metal production. Gold followed at 37.5 percent, along with silver at 9.5 percent, and lead at 9.2 percent. The decreased mineral production value in 2014 compared with 2013 resulted primarily from lower metal prices. The average 2014 price for gold dropped 10.3 percent from the previous year's average. The price of zinc rose 12.6 percent.

$\Rightarrow$ The total value of production slipped 4 percent in the past year to $\$ 3.28$ billion from the 2013 total of $\$ 3.42$ billion.

$\Rightarrow$ Development expenditures in Alaska, down 21.5 percent in 2014 to $\$ 281.7$ million, correlate closely with production expenditures at the major mines; development expenditures at Alaska's major mines account for more than 80 percent of total development expenditures.

$\Rightarrow$ Mineral exploration expenditures decreased dramatically in 2014 to $\$ 96.2$ million, down more than 45 percent from the 2013 level of $\$ 175.5$ million. The total 2014 Alaska exploration budget has dropped to a little more than one-quarter of the 2011 all-time high of $\$ 365.1$ million.

$\Rightarrow$ Mining claims and prospecting sites covered approximately 3.6 million acres of Alaska in 2014, with 6,003 active Federal and 40,729 active State mining claims. State 40- and 160-acre claim staking decreased by almost 50 percent in 2014, while staking of State prospecting sites decreased by 32 percent. More than 75 percent fewer Federal claims were staked in 2014.

$\Rightarrow$ Mineral industry employment in 2014 is estimated at 2,967 full-time-equivalent jobs, an overall decrease of about 1,084 jobs (27 percent) from 2013. Exploration jobs, tracking with the limited number and size of 2014 exploration projects, saw a sharp decrease of 132 jobs (34 percent) from 2013. Production and development job losses were slightly less steep at 952 jobs (26 percent). In particular, 2014 placer mining production employment apparently decreased 49 percent, although a portion of this drop likely reflects changes in source data for this report; the actual decrease may be more in line with mineral industry employment drops in other sectors. As reported by the Alaska Miners Association, the Alaska mineral industry also created an estimated 4,400 indirect jobs in 2014.

$\Rightarrow$ Estimated revenues in 2014 to the State of Alaska and municipalities from mineral-industry-specific fees, rent, sales, royalties, and taxes amounted to more than $\$ 102.2$ million. 


\section{CONTENTS}

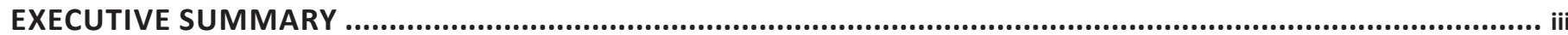

INTRODUCTION

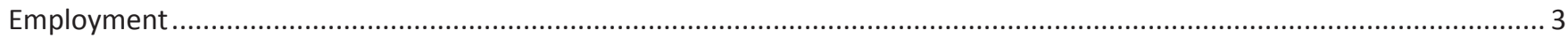

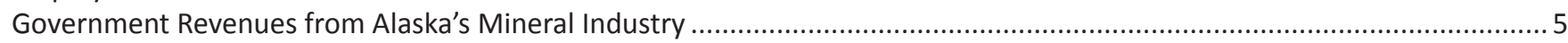

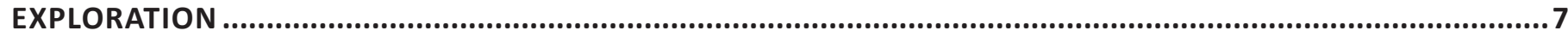

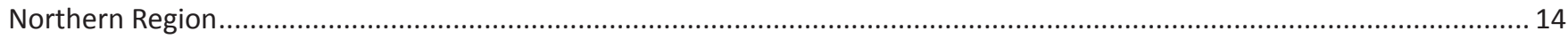

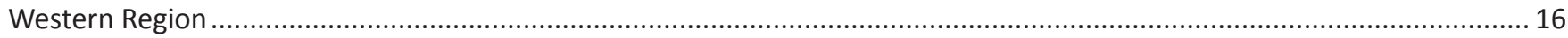

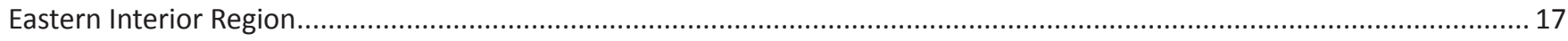

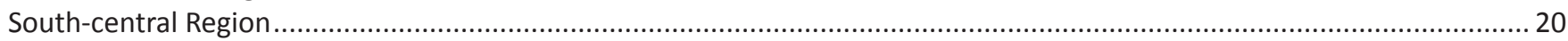

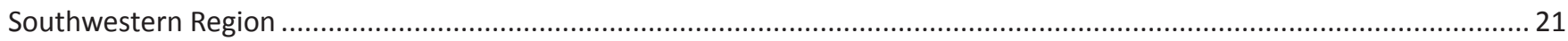

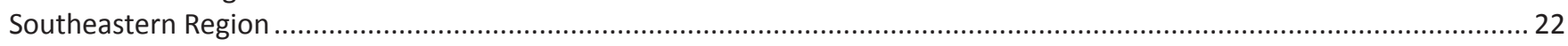

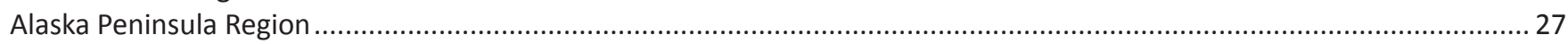

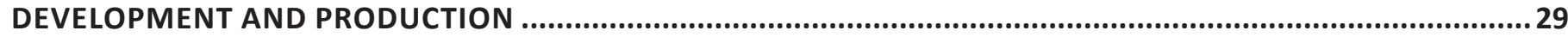

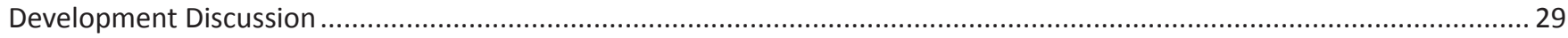

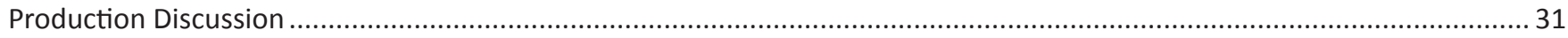

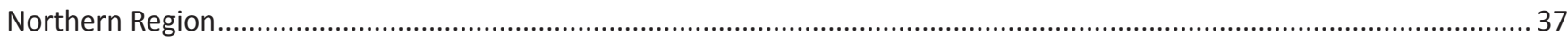

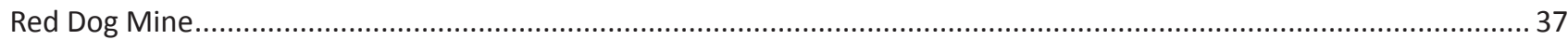

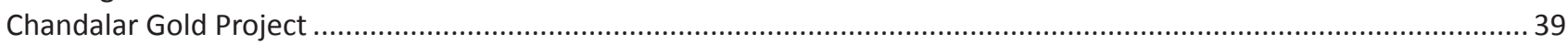

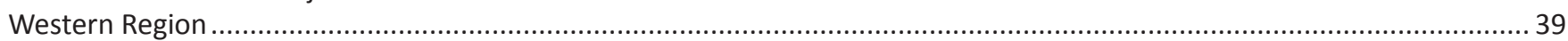

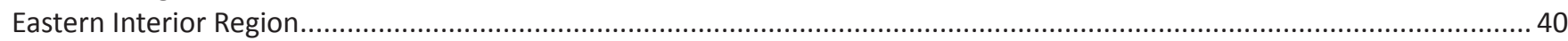

Fort Knox Mine

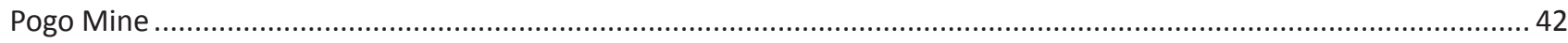

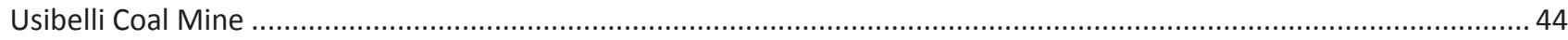

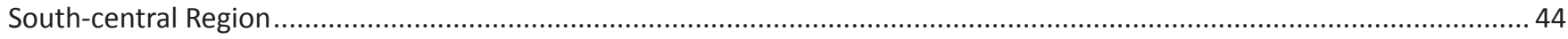

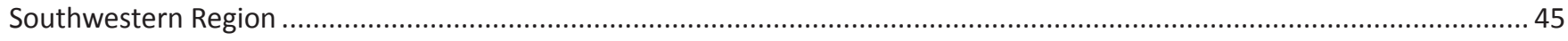

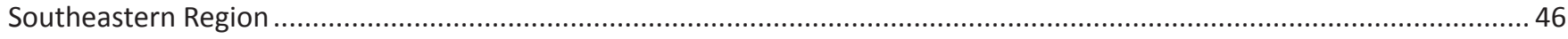

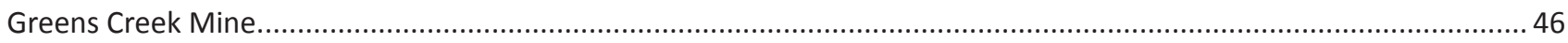

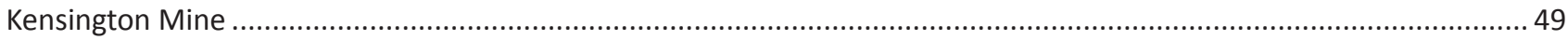

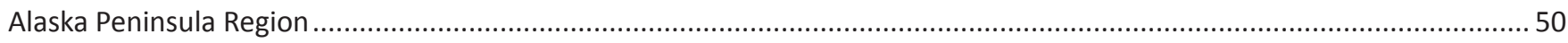

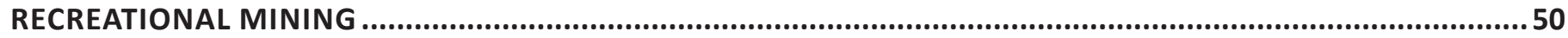

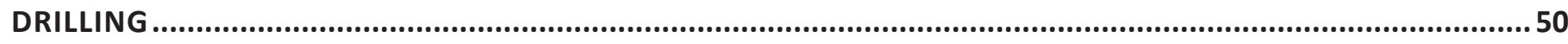

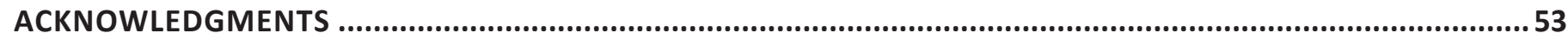

\section{APPENDICES}

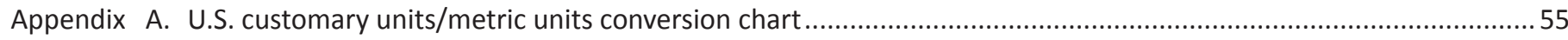

B. Companies and individuals reported to be producing metal in Alaska, 2014 ....................................................56

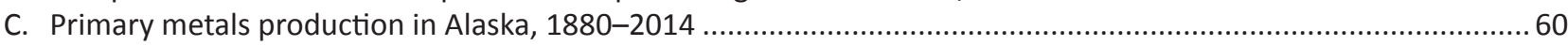

D. Production of industrial minerals, coal, and other commodities in Alaska, 1880-2014.....................................61

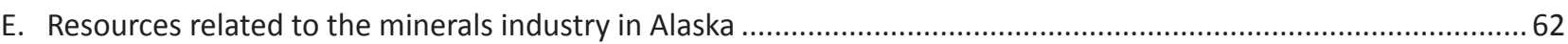

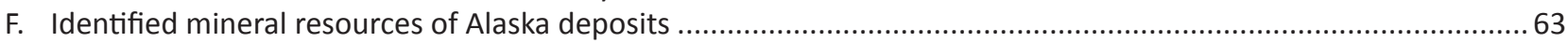




\section{FIGURES}

Figure 1. Exploration and development expenditures and estimated first market value for the mineral industry, 1981-2014 .....2

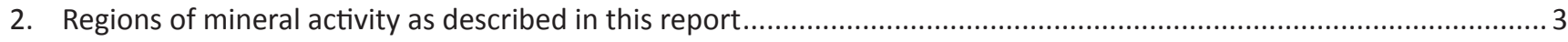

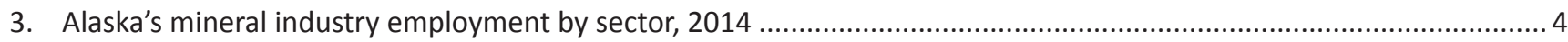

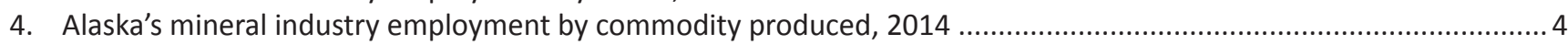

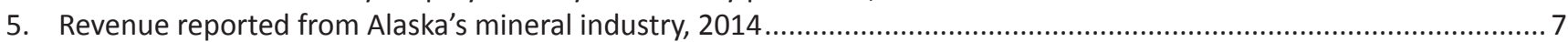

6. Revenue from Alaska's mineral industry, 2005-2014 ................................................................................... 7

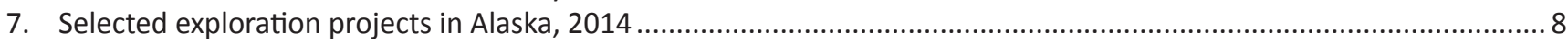

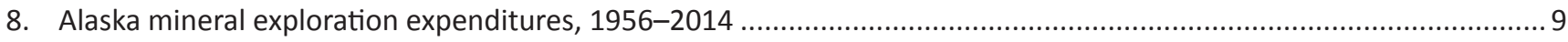

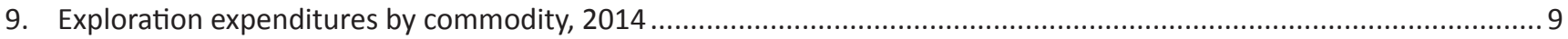

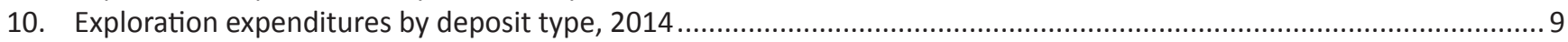

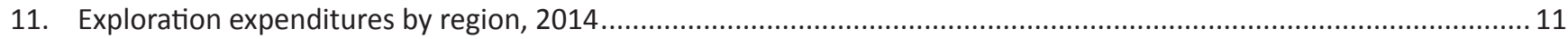

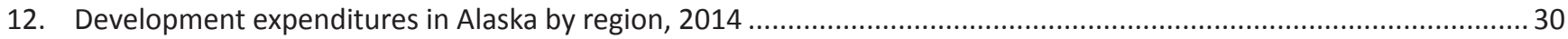

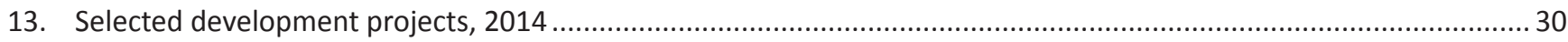

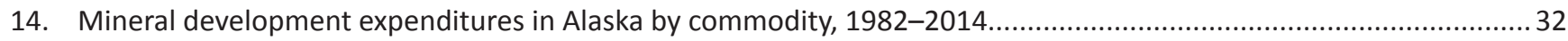

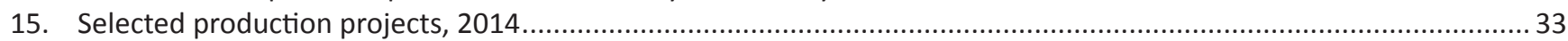

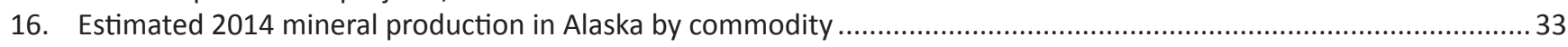

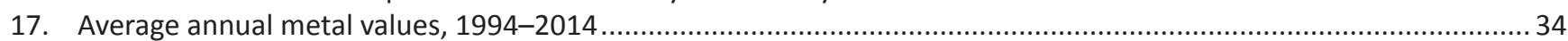

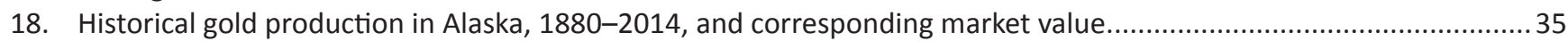

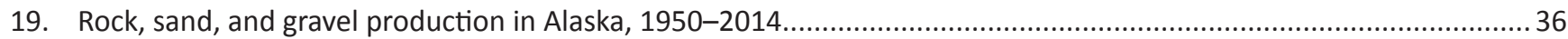

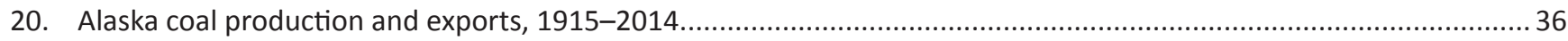

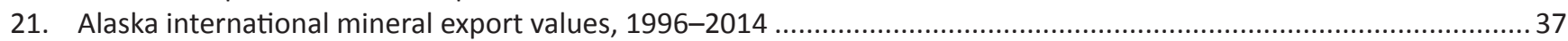

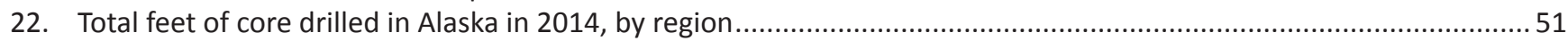

\section{PHOTOS}

Photo 1. DeLong Mountain Transportation System port and ancillary facilities ................................................................ 5

2. DGGS geologist Evan Twelker measuring a foliation surface in Paleozoic metasedimentary rocks in the Talkeetna

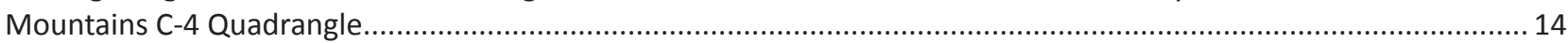

3. Aerial photo of Red Dog Mine in 2014 .................................................................................................. 15

4. Image showing apparent conductivity draped over the topography of the northern Kigluaik Mountains, Seward

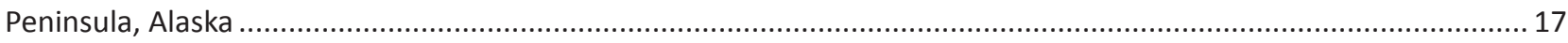

5. Jumbo rock-drilling machine drilling a blast-hole pattern to advance an underground drift at Pogo Mine ..................18

6. Visible gold in dog-tooth quartz vein in core from the LMS deposit northeast of Delta Junction in the Goodpaster

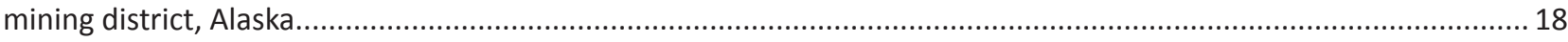

7. Rainer Newberry, of the University of Alaska Fairbanks, describing mineralization at the Copper Joe porphyry

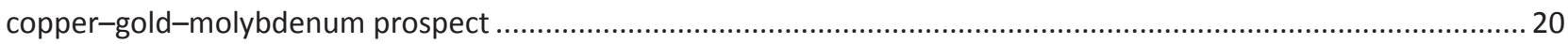

8. Geologists logging core at the Kensington project, northwest of Juneau, in southeastern Alaska .............................22

9. Helicopter slinging core from a drill site at the Palmer project northwest of Haines, Alaska .....................................26

10. First Quantum Minerals Ltd. geologist on outcropping porphyry copper-style mineralization on the Alaska

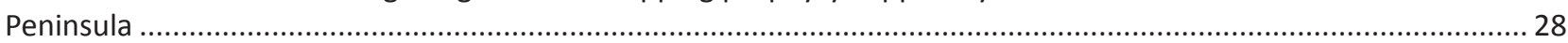

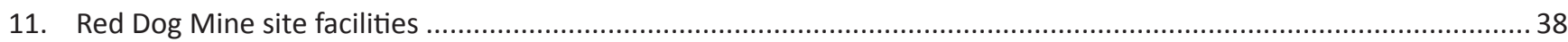

12. One of two "elevated work platforms" operated by Phoenix Offshore Mining Inc. in the Nome offshore lease

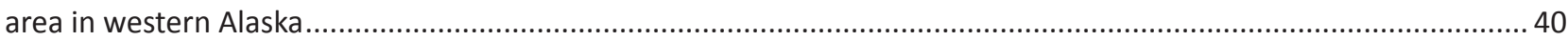

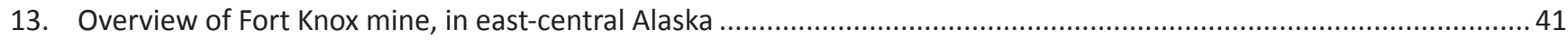

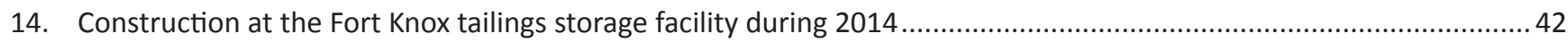

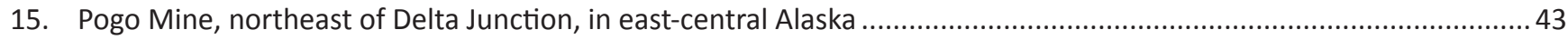

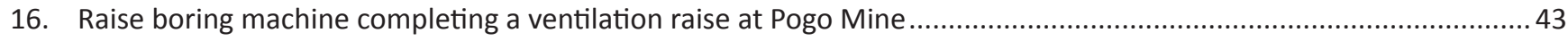

17. Exploration camp and airstrip at the Donlin Gold project site .......................................................................45

18. A portion of the Greens Creek surface and mill facilities on Admiralty Island, 18 miles southwest of Juneau .............. 46

19. Haul truck entering Kensington Mine, a quartz-vein-hosted gold deposit 45 miles northwest of Juneau.................... 49

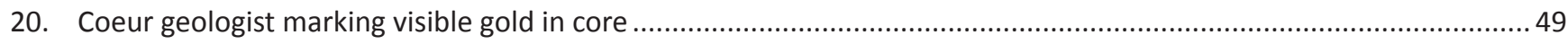

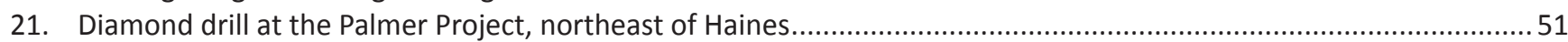




\section{TABLES}

Table 1. Reported annual exploration and development expenditures of the mineral industry and the estimated first market value of mineral production in Alaska, 1981-2014 ............................................................................ 2

2. Estimated Alaska mineral industry employment, 2006-2014 ...........................................................................

3. Reported and estimated revenues paid to the State of Alaska and municipalities by Alaska's mineral industry,

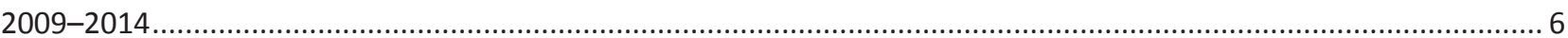

4. Reported exploration expenditures in Alaska by commodity, $1981-2014$............................................................. 10

5. Reported exploration expenditures and employment in Alaska, 2014 ............................................................ 11

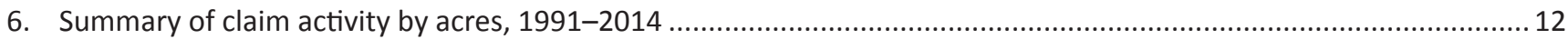

7. Detailed state airborne geophysical surveys and follow-up geologic ground-truth mapping as of December $2014 \ldots . . .13$

8. Detailed federally funded airborne geophysical survey work as of December 2014 ................................................ 14

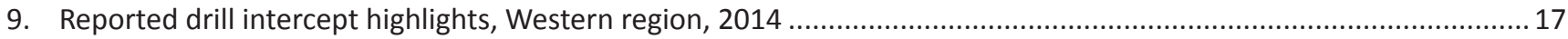

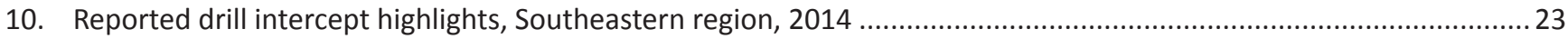

11. Reported mineral development expenditures and employment in Alaska by commodity and region, 2014 ...............29

12. Reported mineral development expenditures in Alaska by commodity, $1982-2014$..............................................31

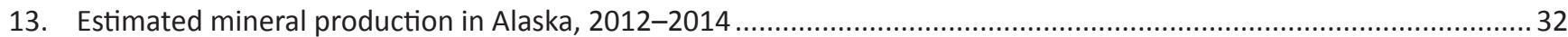

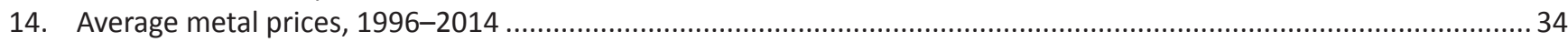

15. Reported refined gold production, number of operators, and industry employment in Alaska, 2012-2014 ...............35

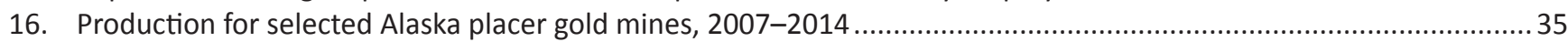

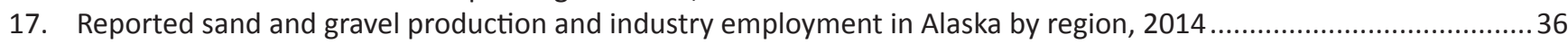

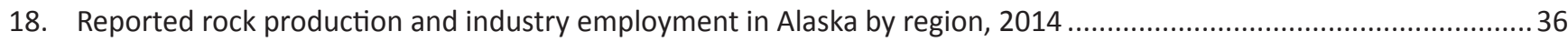

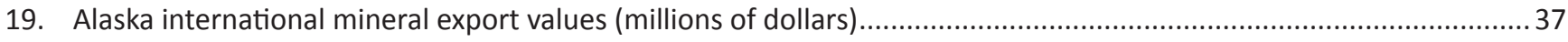

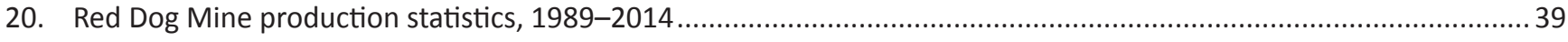

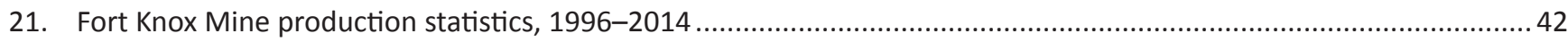

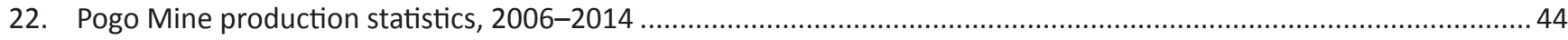

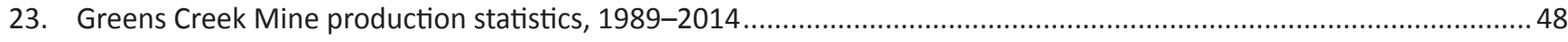

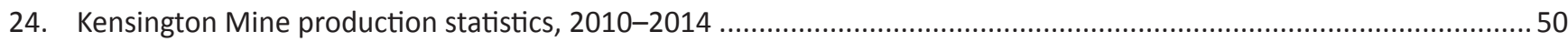

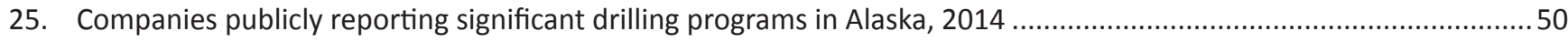

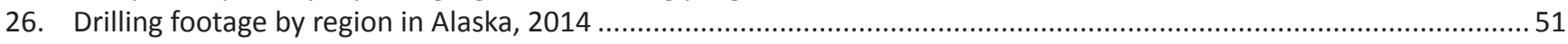

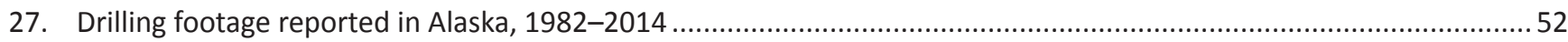




\title{
Alaska's Mineral Industry 2014
}

\author{
L.K. Freeman ${ }^{1}$, J.E. Athey ${ }^{1}$, P.S. Lasley², and E.J. Van Oss ${ }^{3}$
}

INTRODUCTION

Alaska may have a golden heart, but on this silver anniversary of the resumption of large-scale mining in the state it is noteworthy that zinc has been galvanizing Alaska's economy for a quarter century. In 1989 Red Dog and Greens Creek mines started production; in the intervening 25 years the two mines have collectively produced more than 14 million tons of zinc, 2.8 million tons of lead, and 328 million ounces of silver, with byproduct copper, gold, and germanium (tables 20 and 23; appendix C). Both mines have identified resources (appendix F) sufficient for another 15 years of mining and are actively exploring to expand the identified resource base.

Red Dog and Greens Creek exemplify the diversity and quantity of Alaska's mineral endowment, which is highly regarded by exploration and mining companies worldwide-the state is considered among the top three regions of the world for mineral potential ${ }^{4}$. Alaska's mineral potential is evident by historically significant production: placer gold from the Fairbanks and Nome mining districts, copper from the Kennecott area, lode gold from the Alaska-Juneau (A-J) and Treadwell mines near Juneau, and placer platinum from the Goodnews Bay mining district. In addition to Red Dog and Greens Creek, Alaska's other major metal deposits currently in production include Pogo, Fort Knox, and Kensington gold mines. Alaska's annual zinc production equals 5 percent of zinc produced worldwide, and 65 percent of U.S. domestic consumption ${ }^{5}$. The Pebble, Donlin Gold, Money Knob, Arctic, and Bornite deposits collectively represent a significant proportion of domestic gold and copper resources 5 and indicate that there are still extremely large mineral deposits to be developed in Alaska. Significant recently-discovered resources at the Graphite Creek deposit and the Bokan Mountain rare-earth-element deposit promise domestic sources for twenty-first-century technologies. Without doubt, other Alaska mineral deposits remain to be discovered.

Economically viable projects are feasible in Alaska through partnerships of industry and the State-industry investment in Alaska's favorable geology and the State's commitment to responsible, responsive public-land stewardship. Alaska, in its strategic Pacific Rim location, offers prospective land, sanctity of title, State-sponsored geological and geophysical mapping, a reasonable permitting process, a capable workforce, exploration incentives, and inventive infrastructure equity-sharing programs. More than 190 million acres of Federal, State, and Native lands are open for mineral-related activities and mining. This allows the minerals industry to be a driving force in the state's economy through significant local employment, infrastructure, and government revenue. It is the policy of the State of Alaska to encourage the settlement of its land and the development of its resources by making them available for maximum use consistent with the public interest.

Alaska's minerals industry continued to demonstrate its health even though metal prices and worldwide venture capital investment were down in $2014^{6}$. Table 1 and figure 1 show the estimated value of exploration and development investments in the industry and the estimated 'first market value' (estimated gross value of mineral products at first wholesale) of mineral production in Alaska between 1981 and 2014. For purposes of this report, Alaska has been divided into seven geographic regions, shown in figure 2.

Exploration expenditures, a sign of industry interest and future production values, were down 45 percent, from $\$ 175.5$ million in 2013 to $\$ 96.2$ million in 2014. Much of the loss of exploration investment results from the $\$ 61$ million decrease in southwestern Alaska exploration, particularly in the Bristol Bay watershed. The remainder of the drop in Alaska exploration is consistent with a 25 percent worldwide decrease in exploration expenditures 6 . Development expenditures in Alaska totaled \$281.7 million in 2014, down 21.5 percent from 2013 levels. This year marked a full decade of annual development expenditures close to or above $\$ 300$ million and exploration expenditures close to or above $\$ 100$ million. Production

\footnotetext{
${ }^{1}$ Alaska Division of Geological \& Geophysical Surveys, 3354 College Rd., Fairbanks, Alaska 99709-3707; lawrence.freeman@alaska.gov; jennifer.athey@alaska.gov

${ }^{2}$ Data Mine North, 11925 Lugene Ln., Eagle River, Alaska 99577; shane.lasley@dataminenorth.com

${ }^{3}$ Alaska Division of Economic Development, 550 W 7th Ave., Suite 1770, Anchorage, Alaska 99501-3569; eric.vanoss@alaska.gov

${ }^{4}$ Jackson, Taylor, and Green, K.P., 2015, Fraser Institute Annual Survey of Mining Companies, 2014: Vancouver, BC, Fraser Institute, 93 p. http://www.fraserinstitute.org

${ }^{5}$ U.S. Geological Survey, 2015, Mineral commodity summaries 2015: U.S. Geological Survey, 196 p., doi:10.3133/70140094

${ }^{6}$ SNL Metals \& Mining, 2015, World exploration trends 2015: Charlottesville, VA, SNL Metals \& Mining, 11 p.
} 
volumes in lead, zinc, and silver increased from levels in 2013. Alaska gold production in 2014 fell short of the historic 1-million-ounce mark achieved by Alaska miners only twice - in 1906 and 2013. Despite higher lead, zinc, and silver production and strong lead and zinc prices in 2014, the estimated first market value of mineral production decreased 4 percent-from $\$ 3.42$ billion in 2013 to $\$ 3.28$ billion in 2014-a result of substantially lower silver and gold prices and the decline in gold production volume.

Past-year statements issued by mining companies, including press releases and corporate annual and financial reports, as well as phone interviews, replies to questionnaires, and permitting paperwork, are factored into the exploration, development, and production values. Due to inevitable incomplete reporting, the numbers compiled in this report are minimum estimates of the value of Alaska's mineral industry. Average metal prices used in the first market value calculations are based on average daily London PM closing price for gold and silver, and average weekly spot price on the London Metal Exchange for base metals. It is important to note that these prices are used to calculate the estimated first market value of metals produced in the state, but do not take into account the costs of mining, transportation, smelter charges, actual sales, or penalties. Coal prices are estimated from average coal prices for similar grade material around the Pacific Rim. Industrial materials prices are based on regional rates provided by some operators.

This report is a cooperative project between the Alaska Division of Geological \& Geophysical Surveys (DGGS) in the Department of Natural Resources (DNR) and the Division of Economic Development in the Department of Commerce, Community, and Economic Development (DCCED), with additional support from the Division of Mining, Land \& Water (DNR/DMLW), the Department of Labor and Workforce Development (DLWD), and the Department of Revenue (DOR). The agencies involved in producing this report are committed to producing a reliable annual commentary on industry, 1981-2014.
Table 1. Reported annual exploration and development expenditures of the mineral industry and the estimated first market value of mineral production in Alaska (in millions of dollars), 1981-2014. Average annual values are given for 1981-1985, 1986-1990, 1991-1995, and 1996-2000. Individual year totals are provided for 2001-2014.

\begin{tabular}{|cccc|}
\hline Year & $\begin{array}{c}\text { Exploration } \\
\text { Expenditures } \\
\text { (\$ millions) }\end{array}$ & $\begin{array}{c}\text { Development } \\
\text { Expenditures } \\
\text { (\$ millions) }\end{array}$ & $\begin{array}{c}\text { Estimated First } \\
\text { Market Value } \\
\text { (\$ millions) }\end{array}$ \\
\hline $1981-1985$ & $\$ 37.5$ & $\$ 36.3$ & $\$ 204.7$ \\
$1986-1990$ & $\$ 36.2$ & $\$ 109.6$ & $\$ 288.6$ \\
$1991-1995$ & $\$ 33.2$ & $\$ 55.3$ & $\$ 520.1$ \\
$1996-2000$ & $\$ 49.4$ & $\$ 158.7$ & $\$ 917.4$ \\
2001 & $\$ 23.8$ & $\$ 81.2$ & $\$ 917.3$ \\
2002 & $\$ 26.5$ & $\$ 34.0$ & $\$ 1,012.8$ \\
2003 & $\$ 27.6$ & $\$ 39.1$ & $\$ 1,000.7$ \\
2004 & $\$ 70.8$ & $\$ 209.1$ & $\$ 1,338.7$ \\
2005 & $\$ 103.9$ & $\$ 347.9$ & $\$ 1,401.6$ \\
2006 & $\$ 178.9$ & $\$ 3185.7$ & $\$ 2,858.2$ \\
2007 & $\$ 329.1$ & $\$ 396.2$ & $\$ 3,367.0$ \\
2008 & $\$ 347.3$ & $\$ 330.8$ & $\$ 2,427.1$ \\
2009 & $\$ 180.0$ & $\$ 293.3$ & $\$ 2,455.6$ \\
2010 & $\$ 264.4$ & $\$ 271.9 *$ & $\$ 3,126.8$ \\
2011 & $\$ 365.1$ & $\$ 342.4$ & $\$ 3,507.7$ \\
2012 & $\$ 335.1$ & $\$ 358.8$ & $\$ 3,436.1$ \\
2013 & $\$ 175.5$ & $\$ 281.7$ & $\$ 3,418.7$ \\
2014 & $\$ 96.2$ & & $\$ 3,282.1$ \\
\hline Source: Alaska's Mineral Industry reports published annually by DGGS/DCCED & \\
*2011 total missing significant expected data & & \\
See Exploration, Development, and Production sections for further details. & \\
\hline
\end{tabular}

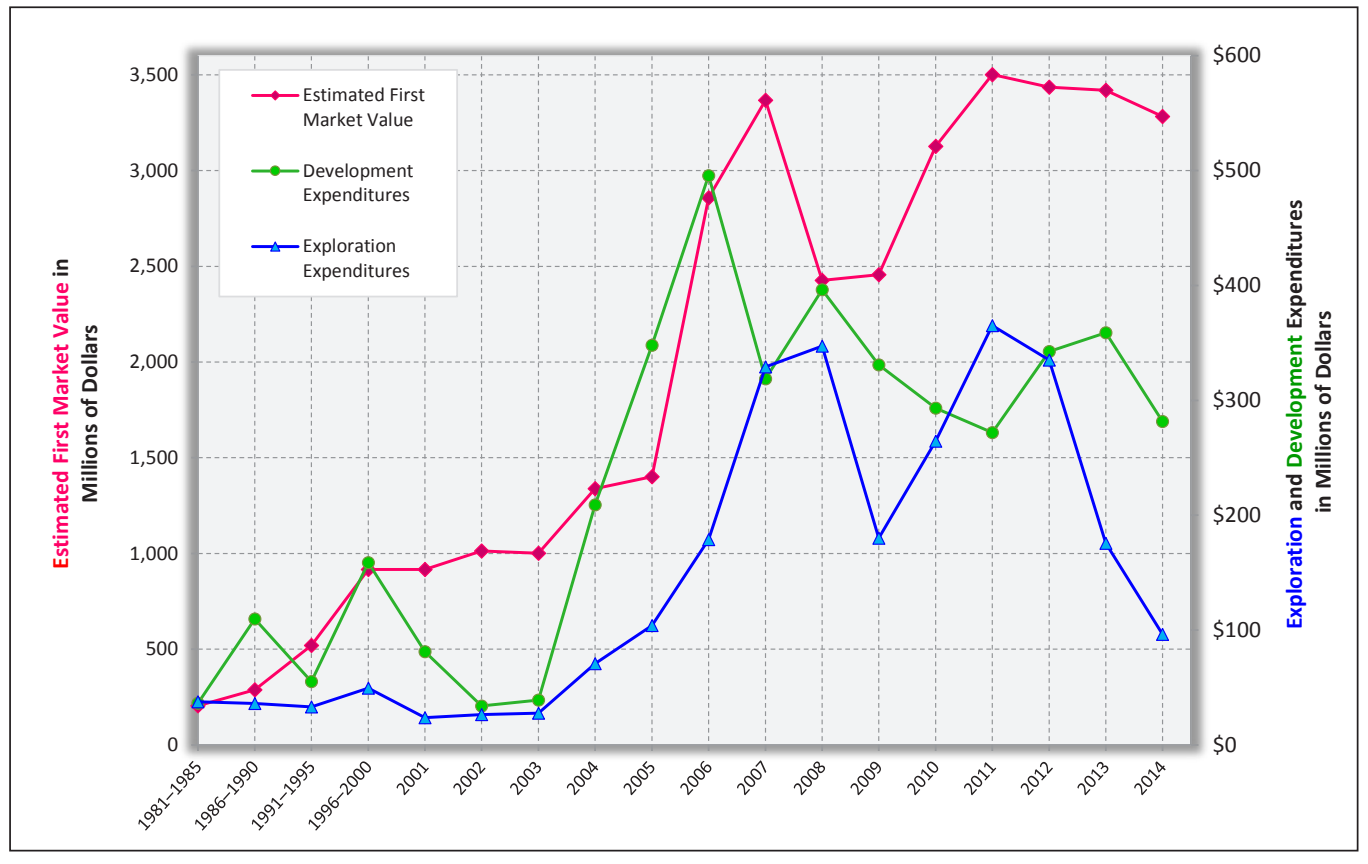

Figure 1. Exploration and development expenditures and estimated first market value for the mineral 


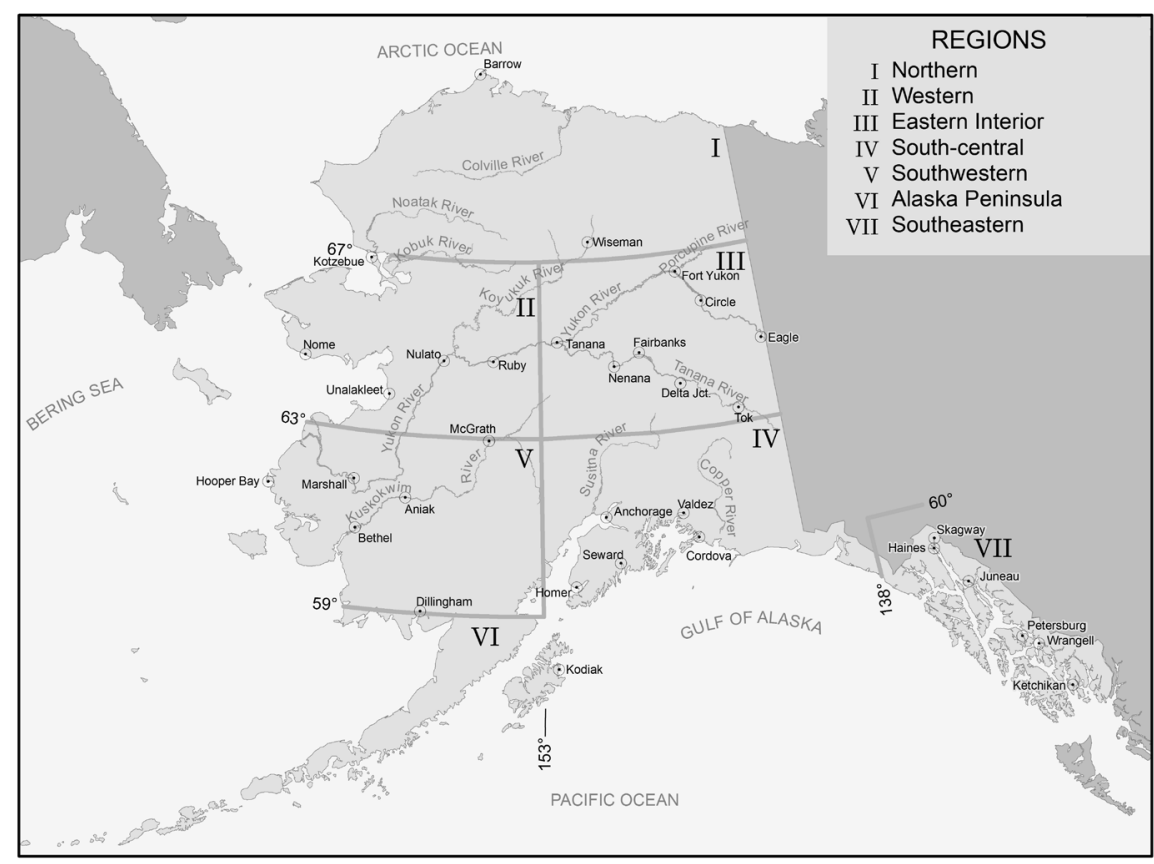

Figure 2. Regions of mineral activity as described in this report.

mineral industry activity in Alaska, which is vital for informed decision-making by state and local governments, the Legislature, land managers, industry, Native corporations, and the public.

\section{A NOTE ABOUT SOME OF THE DIFFERENCES BE- TWEEN THIS REPORT AND THOSE OF PREVIOUS}

YEARS: The formatting and presentation of data in some tables may differ from previous editions of this report, reflecting changes in data collected and accounting practices by the mining industry. Whenever possible, the authors have worked to maintain data consistency for seamless year-toyear comparisons. Most changes are described in footnotes in the affected tables. In the text narrative, starting this year, we now consistently report identified resources, which are defined as the aggregate of proven and probable reserves, measured and indicated resources, and inferred resources ${ }^{7}$. Itemized values for each resource category and for each mine and prospect are tabulated in appendix F. As the authors modernize this annual report by utilizing digital data and technological advances, future products will also include substantial changes in the data sources used to compile the exploration, development, and production information, and the presentation of the economic data in the report.

\section{EMPLOYMENT}

Total mineral industry employment in 2014 is estimated at 2,967 full-time-equivalent jobs, an overall decrease of about 1,084 jobs (27 percent) from 2013 (table 2; fig. 3). Exploration jobs, tracking with the limited number and size of 2014 exploration projects, saw a sharp decrease of 132 jobs ( 34 percent) from 2013. Production and development job losses were slightly less steep at 952 jobs (26 percent). In particular, 2014 placer mining production employment apparently decreased 49 percent, although a portion of this drop likely reflects changes in source data for this report.

Reporting from voluntary responses to questionnaires, Affidavits of Annual Labor, Applications for Permits to Mine in Alaska (APMAs), and other information sources represents a minimum estimate and an incomplete picture of mineral industry employment in Alaska. Most large operators do not differentiate production from development employment; consequently, prior to 2014 some development employment was included in the production employment figures, and development employment was underreported. Values for 2014 development and production employment were estimated for large operations based on their reported ratio of production/development expenditures, which accounts for the 31 percent higher 2014 development employment number of 468 full-time-equivalent jobs. In keeping with minerals industry activity across the state, development employment has likely decreased since 2013.

Employment by commodity depicts a similar story of a decrease in full-time-equivalent jobs across most sectors (fig. 4). Notable changes from 2013 include a sharp drop in placer production employment and recreational mining employment of 239 jobs (49 percent), although an increased reliance on labor reporting in Affidavits of Annual Labor instead of multi-year APMAs might also have contributed to the apparent change. Sand and gravel employment also appears to have decreased by 95 percent ( 535 jobs); however, with 97 fewer operations contributing data to this year's report, this sector is likely significantly underreported.

The Alaska Department of Labor and Workforce Development (DLWD) provided 2014 mining employment and wage statistics based on 115 reporting units (companies) consisting of 60 metal ore, 37 coal and nonmetallic-mineral quarrying, and 18 mining-support-activity units. Among companies in 2014,

${ }^{7}$ U.S. Bureau of Mines and U.S. Geological Survey, 1980, Principles of a Reserve/Resource Classification for Minerals: U.S. Geological Survey Circular 831, 5 p. http://pubs.er.usgs.gov/publication/cir831 


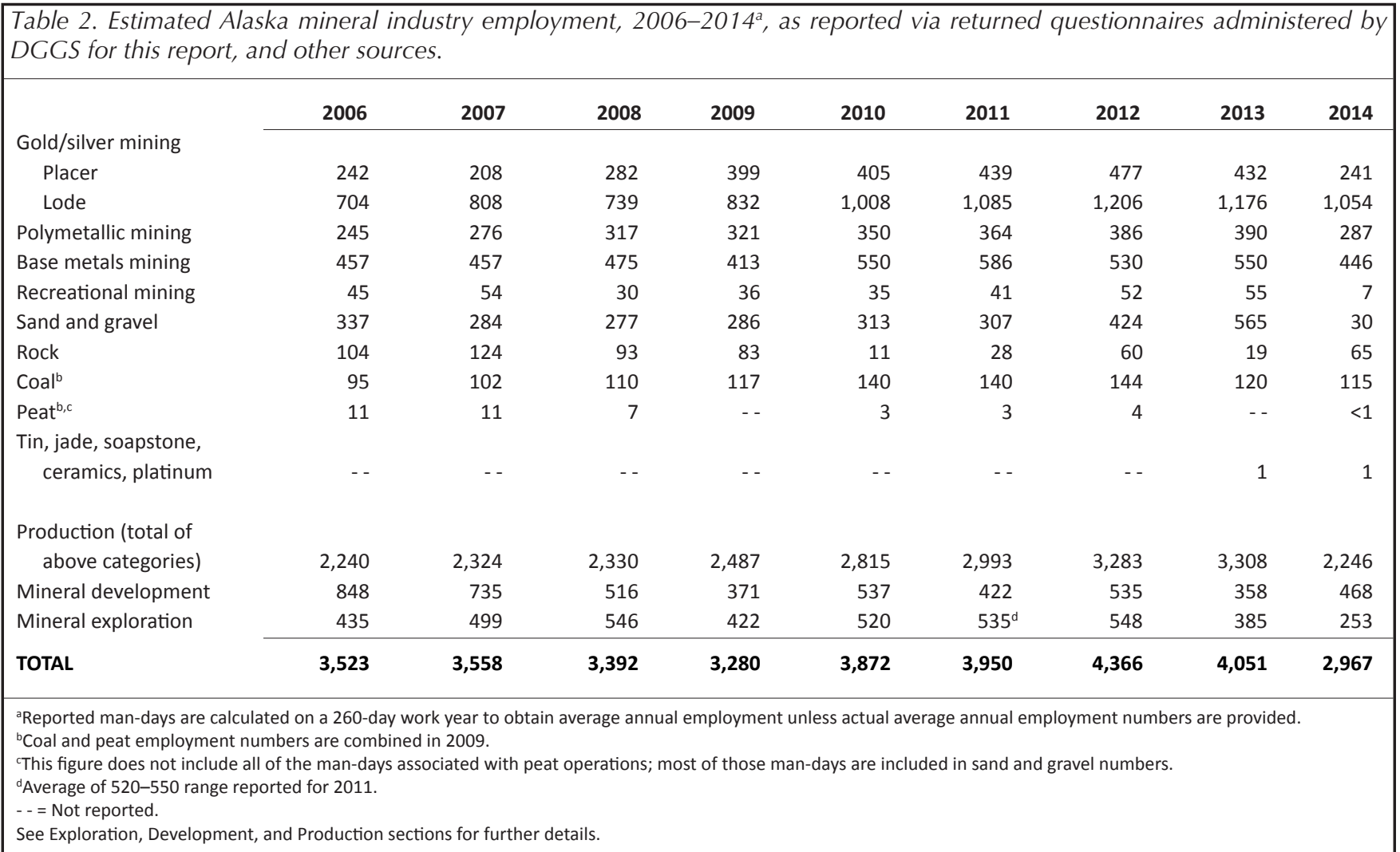

Figure 3. Alaska's mineral industry employment by sector, 2014.

Figure 4. Alaska's mineral industry employment by commodity produced, 2014.
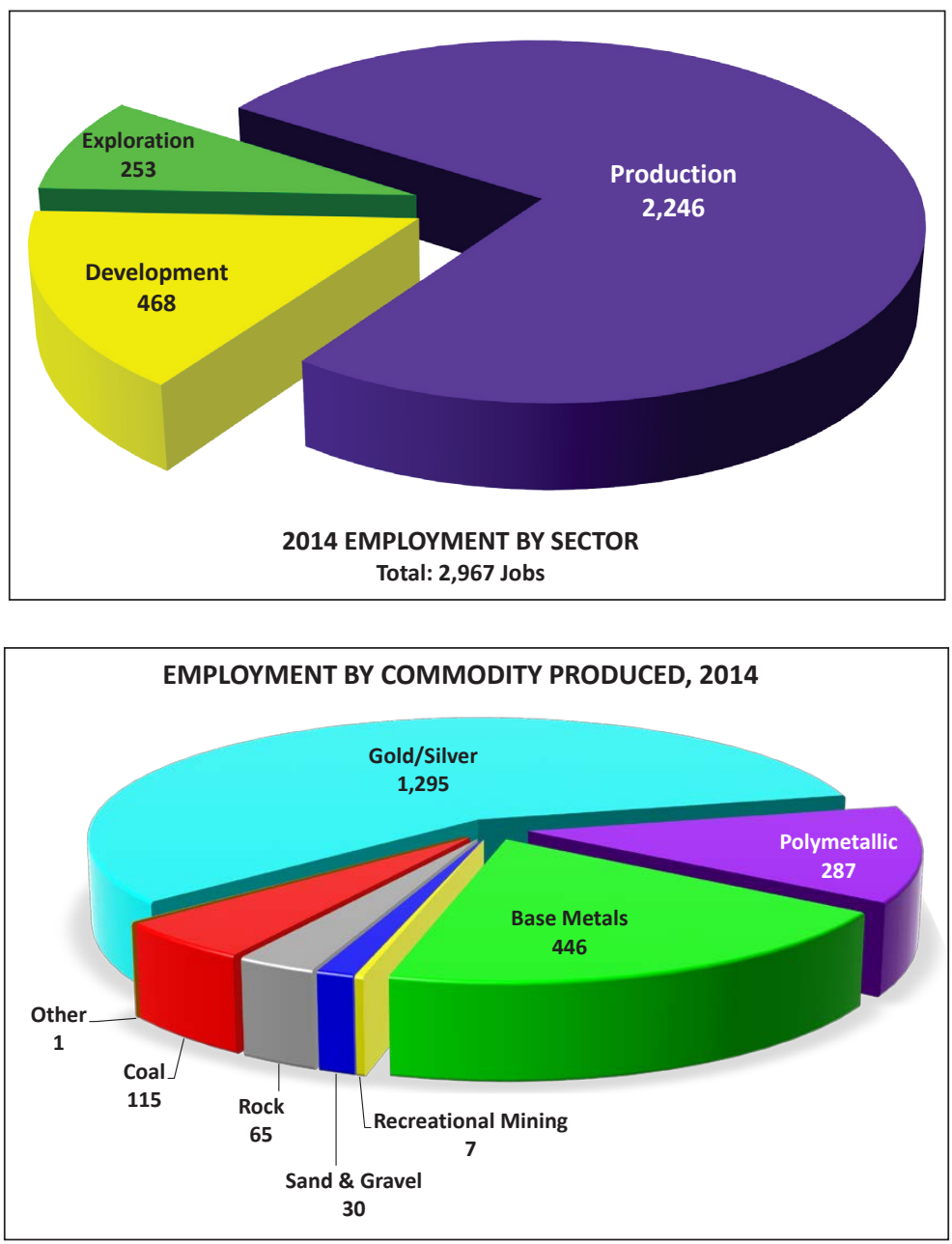
mining and support activities provided 2,906 jobs, down 4 percent from 3,027 jobs in 2013. Average wages for mining-sector jobs are one of the highest among major industries in Alaska, with a 2014 annual average wage of $\$ 105,386$, about twice as much as the average private-sector wage in Alaska, $\$ 52,325$ per year. Total wages paid by non-oil-and-gas mining firms in 2013 were $\$ 296,442,626$, down slightly (1 percent) from 2013 . Total wages paid by mining support firms in 2014 were $\$ 6,893,903$, a 46 percent drop from 2013. Further reflecting the 2014 slump in mineral industry activity, the number of companies providing support activities has decreased by 22 percent, and annual average employment in this sector dropped 36 percent over the last year.

DLWD data show that nonmetallic mineral product manufacturing provided 267 jobs, including an average of 259 jobs in cement and concrete manufacturing for 2014. Primary metal manufacturing provided 18 jobs, while metal and mineral merchant wholesalers provided an average of 133 jobs during 2014 .

DLWD employment is based on wage records and includes part-time jobs but does not include the self-employed and working family members not covered under unemployment insurance. The majority of placer operators are self-employed and are therefore not counted in the DLWD data. Employment data may not include jobs in the exploration and development phases of mining at geological and engineering consulting firms, which are categorized in the engineering, environmental, or construction industries. Consequently, mining's contributions to employment and earnings in Alaska are likely underestimated by DLWD's dataset.

According to DLWD data, 18 boroughs or census areas reported non-oil-and-gas mining employment in 2014. Juneau, Anchorage, Fairbanks North Star Borough (FNSB), and the Southeast Fairbanks Census area each had more than 100 mining jobs. The City and Borough of Juneau and FNSB continue to vie for top spot with 765 and 752 jobs, respectively. FNSB reported a loss of 50 mining and natural resources jobs (3.4 percent) in 2014 , for a 2014 monthly average of 1,400 jobs ${ }^{9}$. The FNSB mining jobs category includes the oil and gas industry, agriculture, forestry, fishing, and hunting as well as hard rock and coal mining, quarrying, and mining support activities. FNSB statistics do not include self-employed workers and unpaid family workers, such as the majority of placer operators.

The Alaska mining industry also created an estimated 4,400 indirect jobs, according to a 2014 study prepared for the Alaska Miners Association (AMA) by McDowell Group Inc. ${ }^{10}$ Mining companies strengthen Alaska's local economies by employing Alaska residents from more than 50 Alaska communities and by purchasing supplies and services from hundreds of Alaska businesses. The AMA study reported the minerals industry paid \$620 million in total direct and indirect payroll in 2014.

\section{GOVERNMENT REVENUES FROM ALASKA'S MINERAL INDUSTRY}

In 2014 government revenue from Alaska's mineral industry totaled $\$ 102,225,300$, representing a 28.3 percent decline from 2013. Table 3 provides an itemized listing of estimated revenues paid to the State and municipalities (photo 1). These revenues are incomplete and serve only as a minimum. For a graphic depiction of revenues, see figure 5. Declines in government revenue are consistent with a broad, two-year slump in commodity prices, which has strained both mining companies

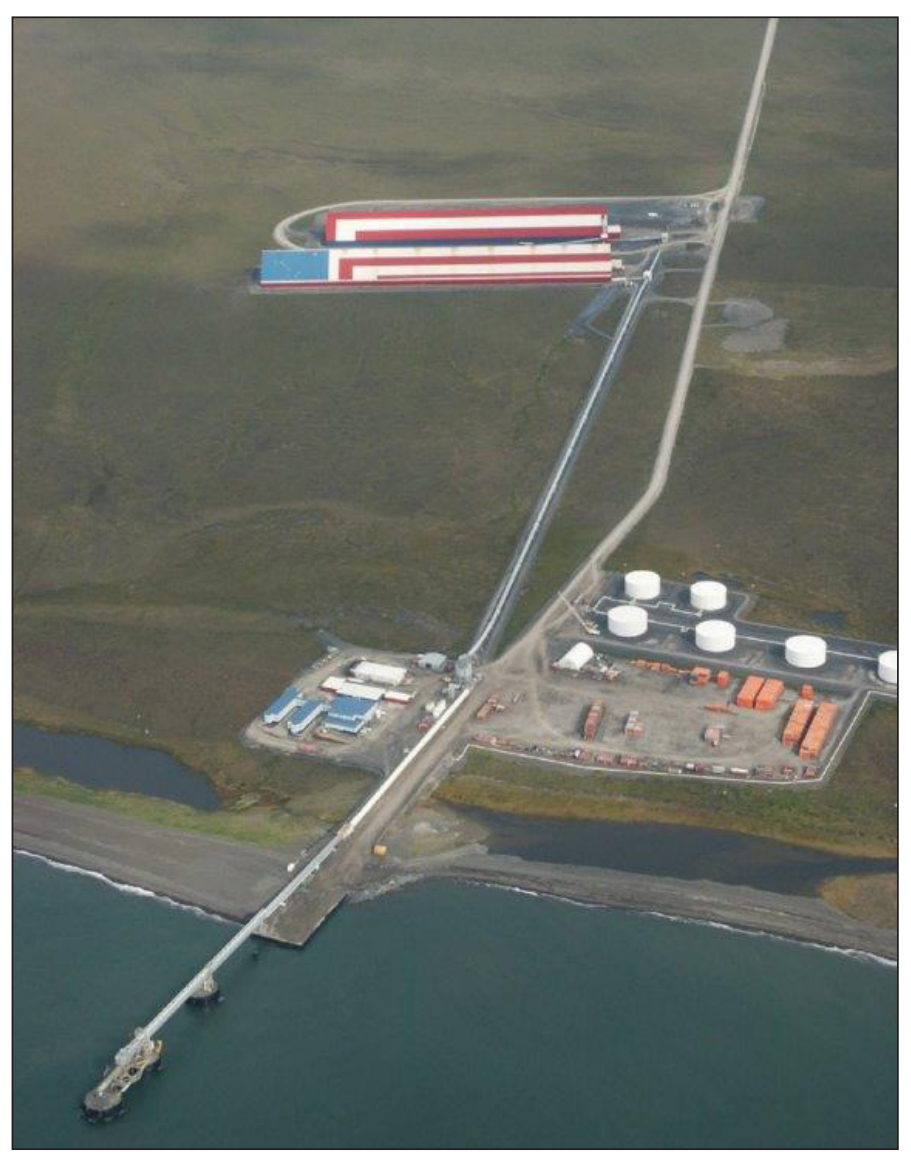

Photo 1. DeLong Mountain Transportation System port and ancillary facilities. The DMTS is owned by AIDEA and has generated $\$ 400$ million in revenues since 1989. Photo courtesy of Teck Alaska Inc.

\footnotetext{
${ }^{8}$ State of Alaska Department of Labor and Workforce Development, Research and Analysis Section, Quarterly Census on Employment and Wages (QCEW), last accessed September 4, 2015. http://labor.alaska.gov/research/qcew/ee14.pdf

${ }^{9}$ Fairbanks North Star Borough's Community Research Quarterly: A Socio-Economic Review, spring 2015, Volume XXXVIII, No. 1, last accessed 9/8/2015. ftp://co.fairbanks.ak.us/Community Research Center/Quarterly Archive/2015SPRINGCRQ.pdf

${ }^{10}$ Alaska Miners Association, last accessed September 4, 2015. http://alaskaminers.org/economic-impact
} 
and jurisdictions that depend on minerals revenue. Fueled by greater demand from emerging markets, many resource-rich jurisdictions saw large increases in production and exploration between 2010 and 2013. Falling revenue is not unique to Alaska, as many countries have seen dramatic revenue reductions due to sharp material price declines linked to slowing economic growth in China, the world's top industrial metals consumer ${ }^{11}$. This situation is comparable to the crisis the State of Alaska currently faces with slumping oil prices. Natural-resource-dependent jurisdictions are facing limited revenue potential as worldwide market forces drive commodity prices to multi-year lows. In Alaska this period saw record revenue to state and local governments, peaking at $\$ 142,548,894$ in 2013 . Minerals prices were volatile, with some in full collapse during 2014 and several commodities, such as gold, reached multi-year lows. Subsequently, government revenue collections from the minerals industry in

Table 3. Reported and estimated revenues paid to the State of Alaska and municipalities by Alaska's mineral industry, 2009-2014. See footnotes for reporting sources and dates.

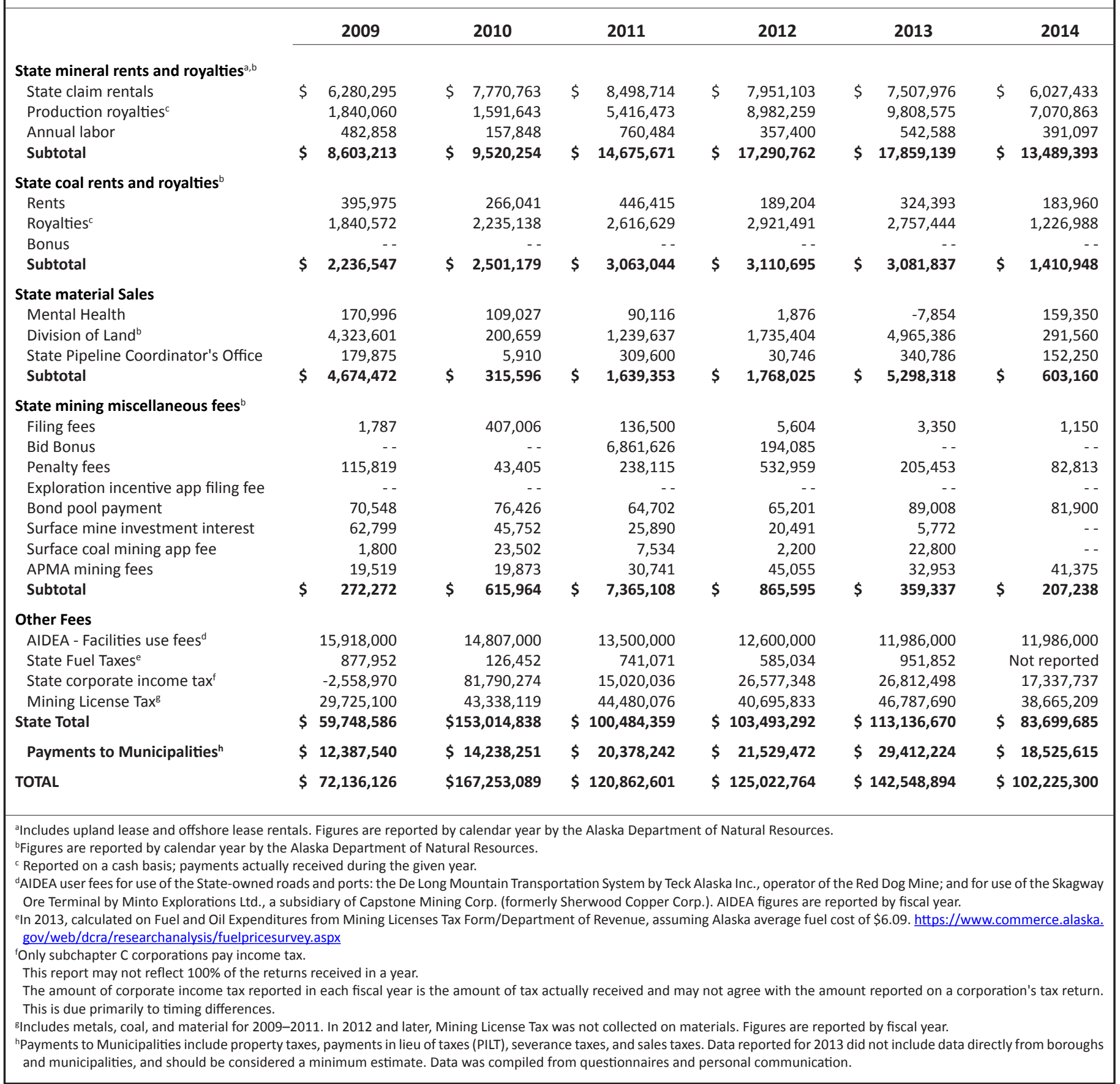

${ }^{11}$ http://www.nasdaq.com/article/industrial-metals-reel-under-topsy-turvy-china-cm515348 
Alaska declined as rents, royalties, and material sales dropped. While state revenue from minerals and mining activity dropped considerably from recent years, it is important to note that historical yearly collections have fluctuated wildly and 2013 numbers can be viewed as more of an exception than the norm (fig. 6). Despite revenue and payment declines to local governments in 2014, revenue remained strong and in many locations - such as Juneau, Fairbanks, and the Northwest Arctic Borough-revenue from miningrelated activity was among the largest contributors to municipal and borough budgets ${ }^{12}$. More information about the various sources of revenue is available from the individual agencies (appendix E).

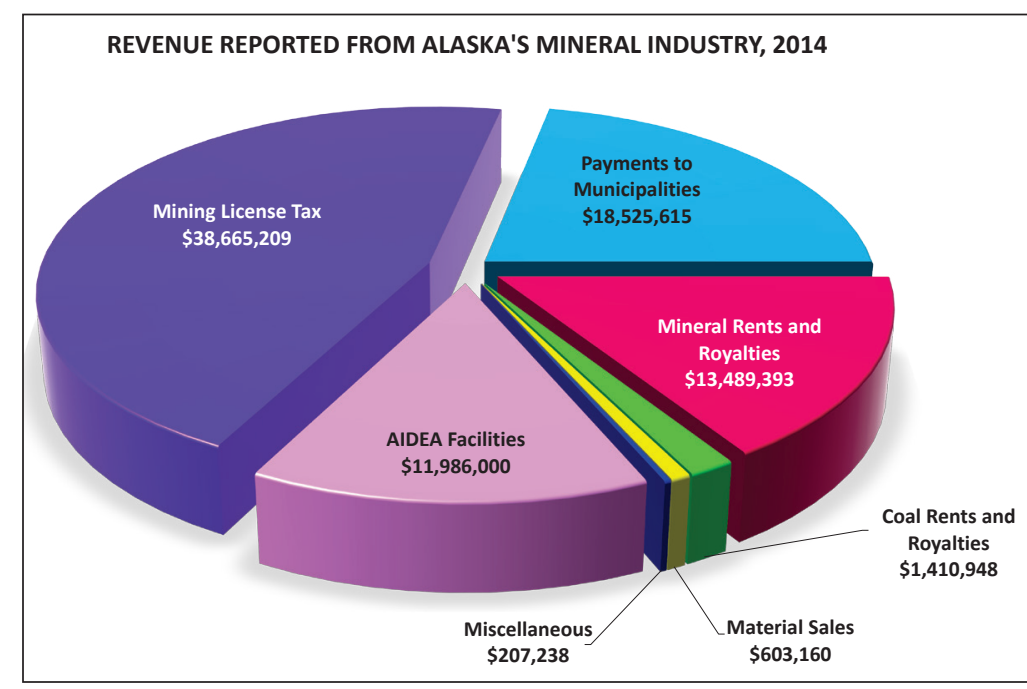

Figure 5. Revenue reported from Alaska's mineral industry, 2014.

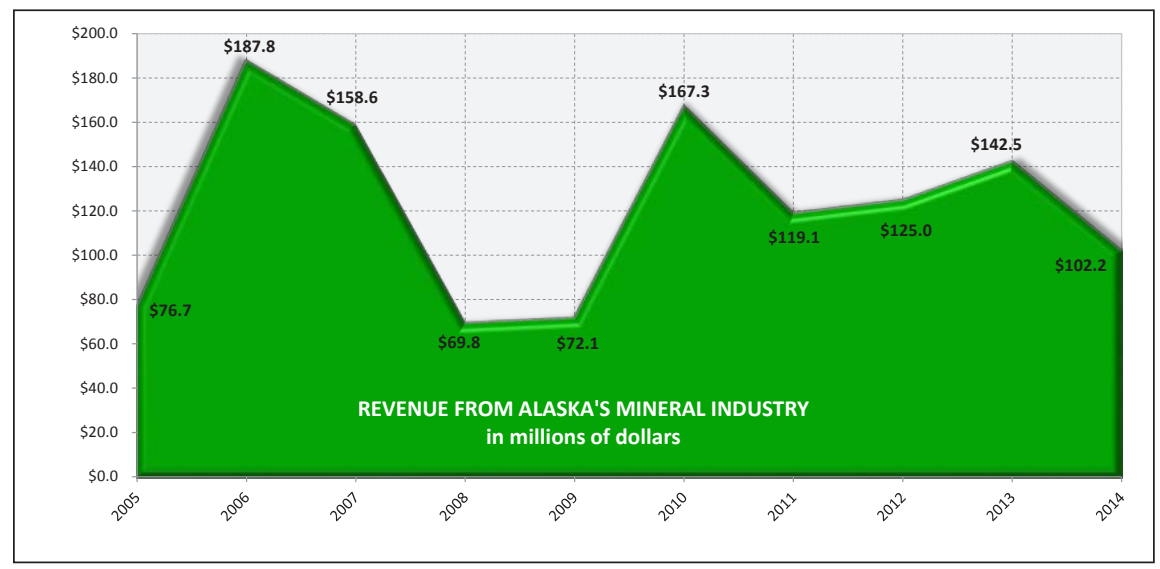

Figure 6. Revenue from Alaska's mineral industry, 2005-2014.

\section{EXPLORATION}

Mineral exploration expenditures in Alaska during 2014 were $\$ 96.2$ million, down 45 percent from the $\$ 175.1$ million reported in 2013. The largest proportion of this drop in exploration expenditures was experienced in southwestern Alaska, where the two largest contributing partners in the Pebble project elected to cease participation. Continuing questions concerning the regulatory and political viability of large-scale mining on land in the Bristol Bay watershed selected by the State for its mineral potential overshadow the tremendous geologic potential of the region as a domestic source of copper, gold, and molybdenum as well as future revenues to State and local governments. The remainder of the drop in Alaska exploration is consistent with a 25 percent worldwide decrease in exploration expenditures ${ }^{13}$. Despite traditional industry challenges such as volatile metal prices and a competitive venture capital market, mineral exploration companies continued to invest in Alaska's favorable geology as prospective partners in Alaska's future through the creation of local jobs, infrastructure, and government revenue. Figure 7 shows the location of the most significant exploration projects in Alaska during the year.

The total mineral exploration expenditures in Alaska from 1956 through 2014 are illustrated in figure 8. Annual exploration expenditures are shown as both actual values and inflationadjusted (to 2014) dollars. During the last decade, exploration expenditures have exceeded those of any previous era of mineral exploration in Alaska over the past 60 years, paralleling an unprecedented worldwide trend; since 2005, global annual exploration expenditures have exceeded $\$ 5$ billion ${ }^{13}$.

Table 4 details exploration expenditures by commodity for the past three decades, while figure 9 summarizes the 2014 data

\footnotetext{
${ }^{12}$ http://www.akbizmag.com/Alaska-Business-Monthly/November-2013/Alaska-Mining-Industry-Update/ and http://www.agcak.org/NewsTidbits/MiningEconomiclmpactBrochure4-3-15.pdf

${ }^{13}$ SNL Metals \& Mining, 2015, World exploration trends 2015: Charlottesville, VA, SNL Metals \& Mining, 11 p.
} 


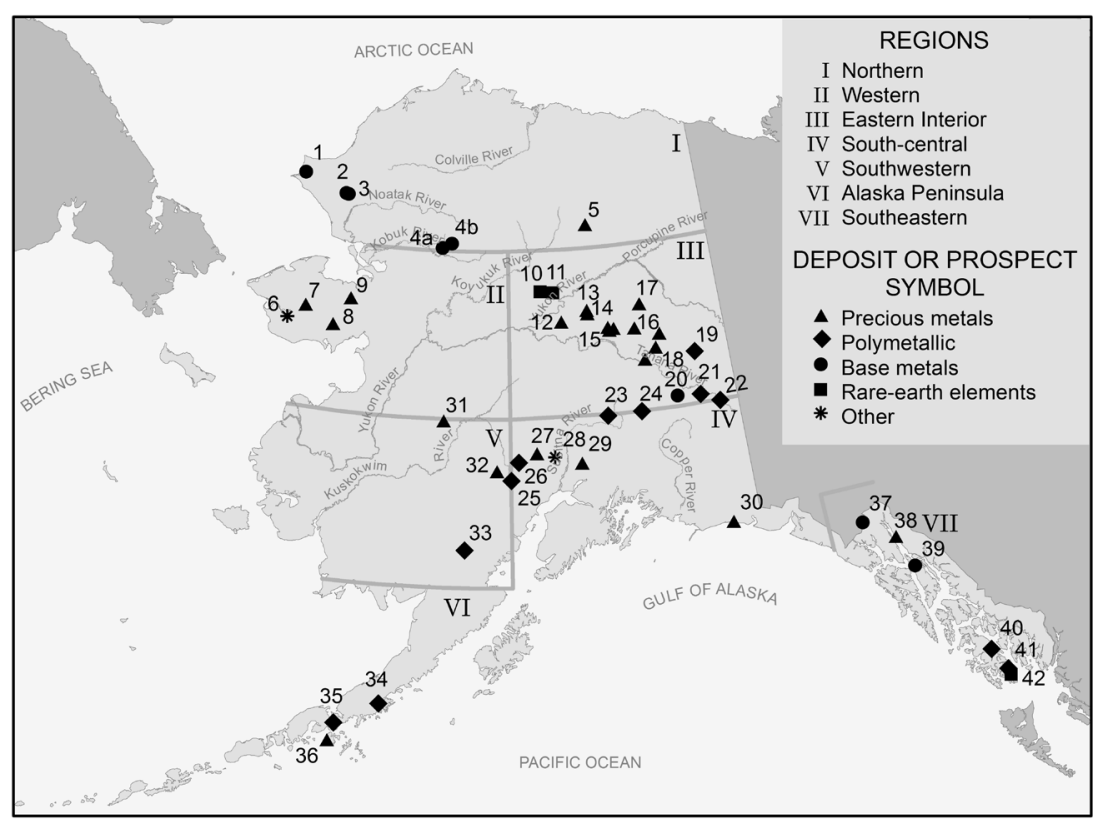

\section{Northern Region}

1. Lisburne-Millrock Resources Inc.

2. Lik-Zazu Metals Corp.

3. Red Dog Mine area-Teck Alaska Inc.

4. Upper Kobuk (Bornite [4a] and Ambler [4b]) NovaCopper Inc.

5. Chandalar-Goldrich Mining Co.

II. Western Region

6. Graphite Creek-Graphite One Resources Inc.

7. Kougarok mining district (placer)—Mammoth Valley Mining LLC

8. Council mining district/area (placer)—Dry Creek Valley LLC

9. Scout-Kuluu-NANA Regional Corp.

III. Eastern Interior Region

10. Sithylemenkat-Doyon Limited

11. Ray River-Ucore Rare Metals Inc.

12. Elephant Mountain—Endurance Gold Corp.

13. Livengood (Money Knob) - International Tower Hill Mines Ltd.

14. Shorty Creek-Freegold Ventures Ltd.

15. Fairbanks District

a. Fort Knox and district-Fairbanks Gold Mining Inc.

b. Golden Summit—Freegold Ventures Ltd.

c. Gil-Kinross Gold Inc.

16. Fairbanks mining district (placer)—William Bohan

17. PB and nearby claims-Kinross Gold Inc.

18. Pogo-Goodpaster mining district

a. Stone Boy (Ink)—Sumitomo Metal Mining/ Stone Boy Inc.

b. Pogo-Sumitomo Metal Mining Pogo LLC

c. LMS—Corvus Gold Inc.
19. LWM-Doyon Limited

20. Delta-Agnico Eagle Mines Ltd.

21. Tetlin-Contango ORE Inc.

22. Northway-Doyon Limited

\section{South-central Region}

23. Nikolai-MMG USA Exploration LLC

24. MAN—Pure Nickel Inc.

25. Copper Joe-Kiska Metals Corp.

26. Whistler-Kiska Metals Corp.

27. Yentna mining district (placer)—Jim Espinola

28. Sable Elegance-Diamond Gold Corp.

29. Willow Creek-Miranda Gold Corp.

30. Cape Yakataga (beach placer)_Yakataga Mining Co. Inc.

V. Southwestern Region

31. Innoko mining district (placer)—C.W. Properties LLC

32. Terra-WestMountain Gold Inc.

33. Pebble-The Pebble Limited Partnership

VI. Alaska Peninsula Region

34. Alaska Peninsula-Millrock Resources Inc.

35. Pyramid-Full Metal Minerals Ltd.

36. Unga-Popov—Redstar Gold Corp.

VII. Southeastern Region

37. Palmer-Constantine Metal Resources Ltd.

38. Kensington/Jualin-Coeur Alaska Inc.

39. Greens Creek Mine-_Hecla Greens Creek Mining Co.

40. Salt Chuck—Pure Nickel Inc.

41. Niblack-Heatherdale Resources Ltd.

42. Bokan Mountain/Dotson Ridge-Ucore Rare Metals Inc.

Figure 7. Selected exploration projects in Alaska, 2014. 


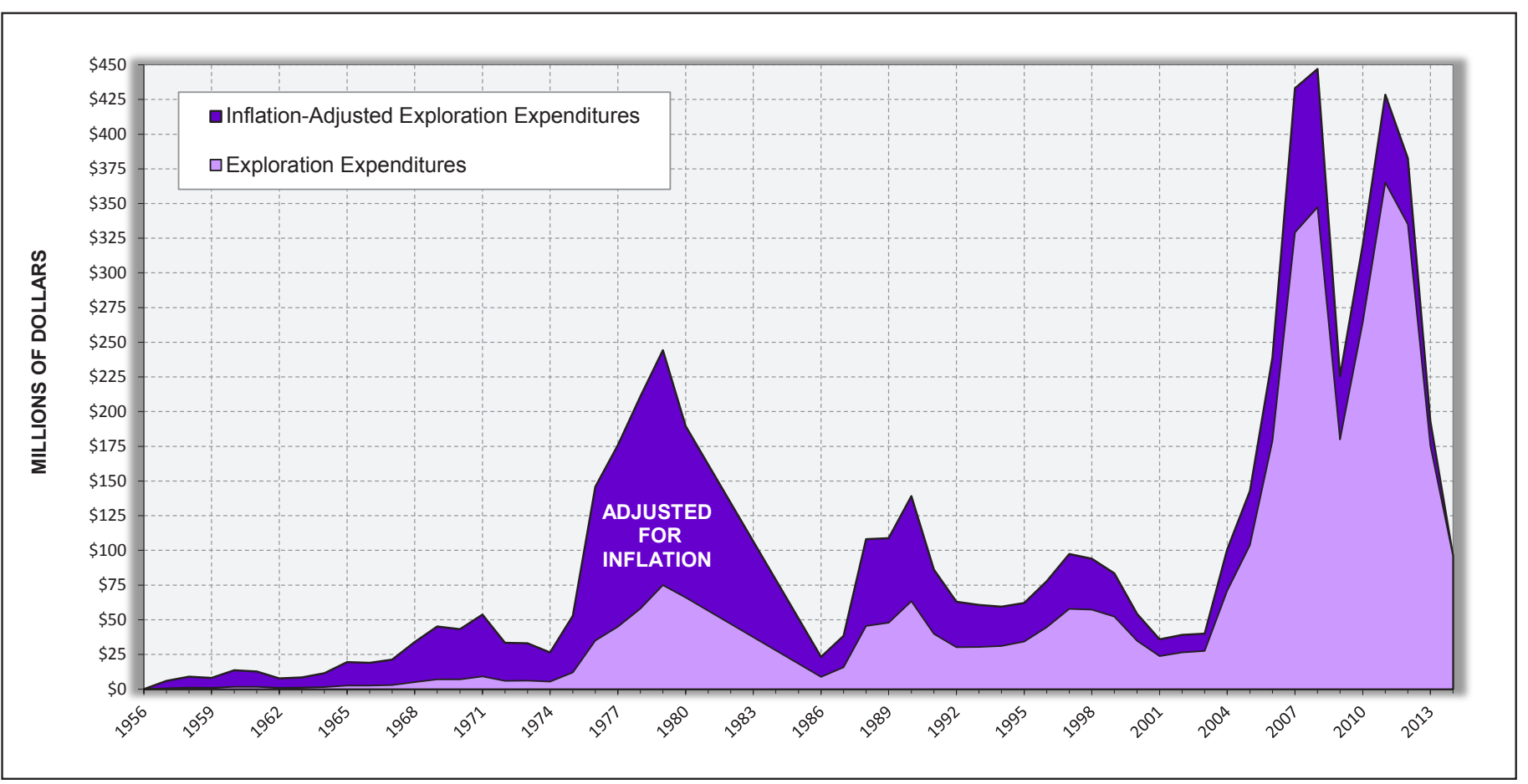

Figure 8. Alaska mineral exploration expenditures, 1956-2014. Curve in background is adjusted for inflation to 2014 dollars.

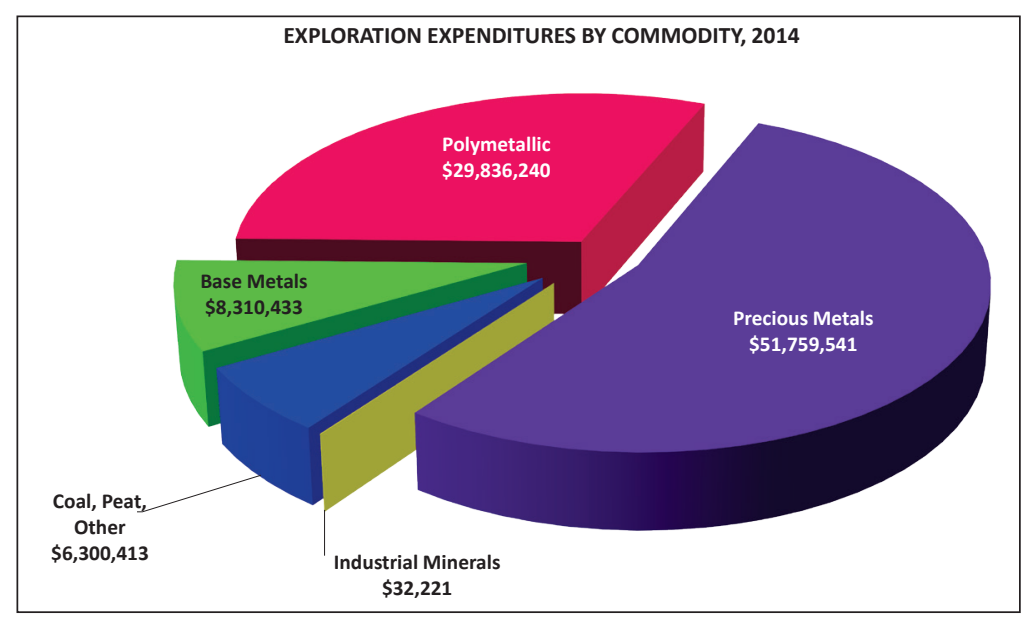

Figure 9. Exploration expenditures by commodity, 2014.

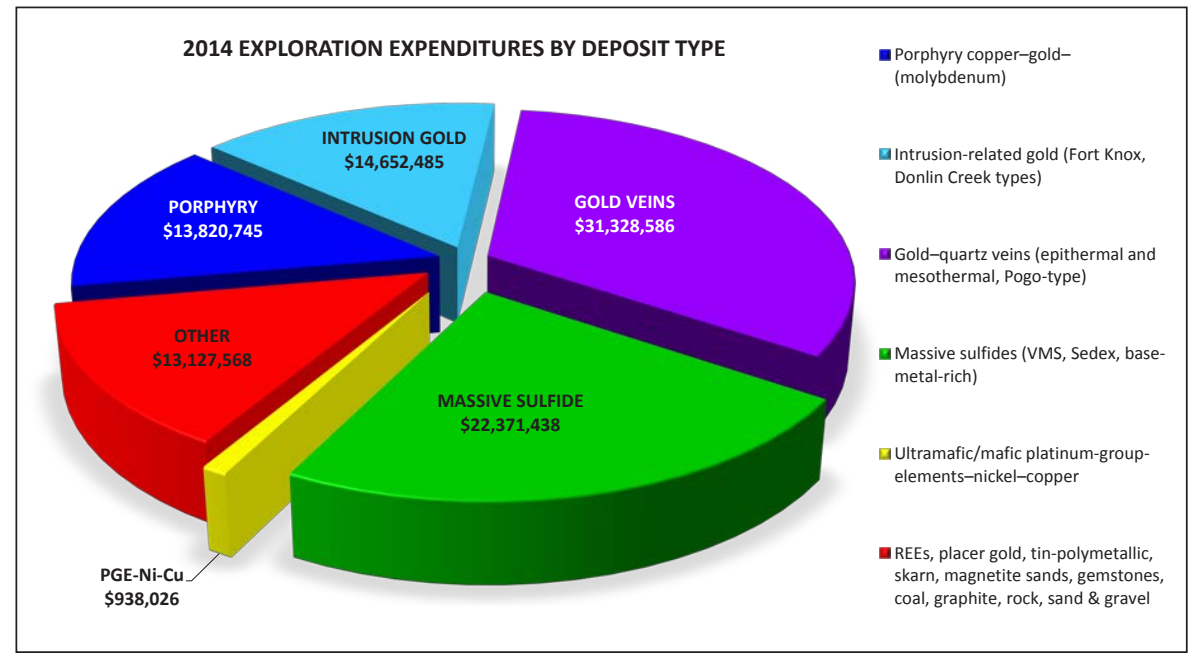

Figure 10. Exploration expenditures by deposit type, 2014. graphically. Exploration was conducted in Alaska during 2014 for a wide variety of metal suites with precious metals exploration (predominantly gold) receiving 54 percent of the share, compared to a 35 percent share in 2013. Notably, expenditures for polymetallic exploration (including porphyry copper-gold-molybdenum systems) in 2014 decreased 71 percent from the 2013 level, largely due to the loss of the major investment partners in the Pebble project. Polymetallic exploration accounted for 31 percent of total exploration expenditures in 2014, only half of the 59 percent share in 2013.

Figure 10 shows 2014 Alaska exploration expenditures by mineral deposit type. Expenditures in all deposit types decreased from 2013 with the exception of gold vein deposits, which saw an $\$ 11.1$ million increase and the largest share in expenditures in 2014, largely due to major exploration efforts at Pogo and Kensington mines. Porphyry copper-gold-molybdenum systems slid from being the major exploration target in 2013 with more than $\$ 77$ million in expenditures to less than $\$ 14$ million in 2014. A single megaproject such as Pebble has a disproportionate effect on statewide trends; in 2013 the expenditures on the Pebble project accounted for 86 percent of all exploration conducted on porphyry deposits; in 2014 the Pebble share of the porphyry sector was still 81 percent. 
Exploration on intrusive-related gold deposits also saw a large drop in 2014. The focus on exploration in Alaska in 2014 was on high-value-per-ton gold veins and massive-sulfide deposits, which together account for 56 percent of exploration statewide. Along with Pogo and Kensington, Red Dog, the Palmer project, and Greens Creek spent significant amounts that contributed to this trend. The Graphite Creek and Bokan Mountain REE projects, which fall into the Other category, could be considered high-value-per-ton projects and had significant exploration expenditures.
Exploration was distributed across Alaska, as shown in table 5 and figure 11 . The center of exploration shifted from the Southwestern region, which had 42 percent of the expenditures in 2013, into the Eastern Interior and Southeastern regions, which combined for a 65 percent share of 2014 exploration expenditures. Spending on exploration in the Southwestern region fell 82 percent from 2013 to 2014, largely due to the sharp reduction in exploration at the Pebble Project. In contrast, the Southeastern region exploration expenditures increased 43 percent to a share of 27 percent of total expenditures.

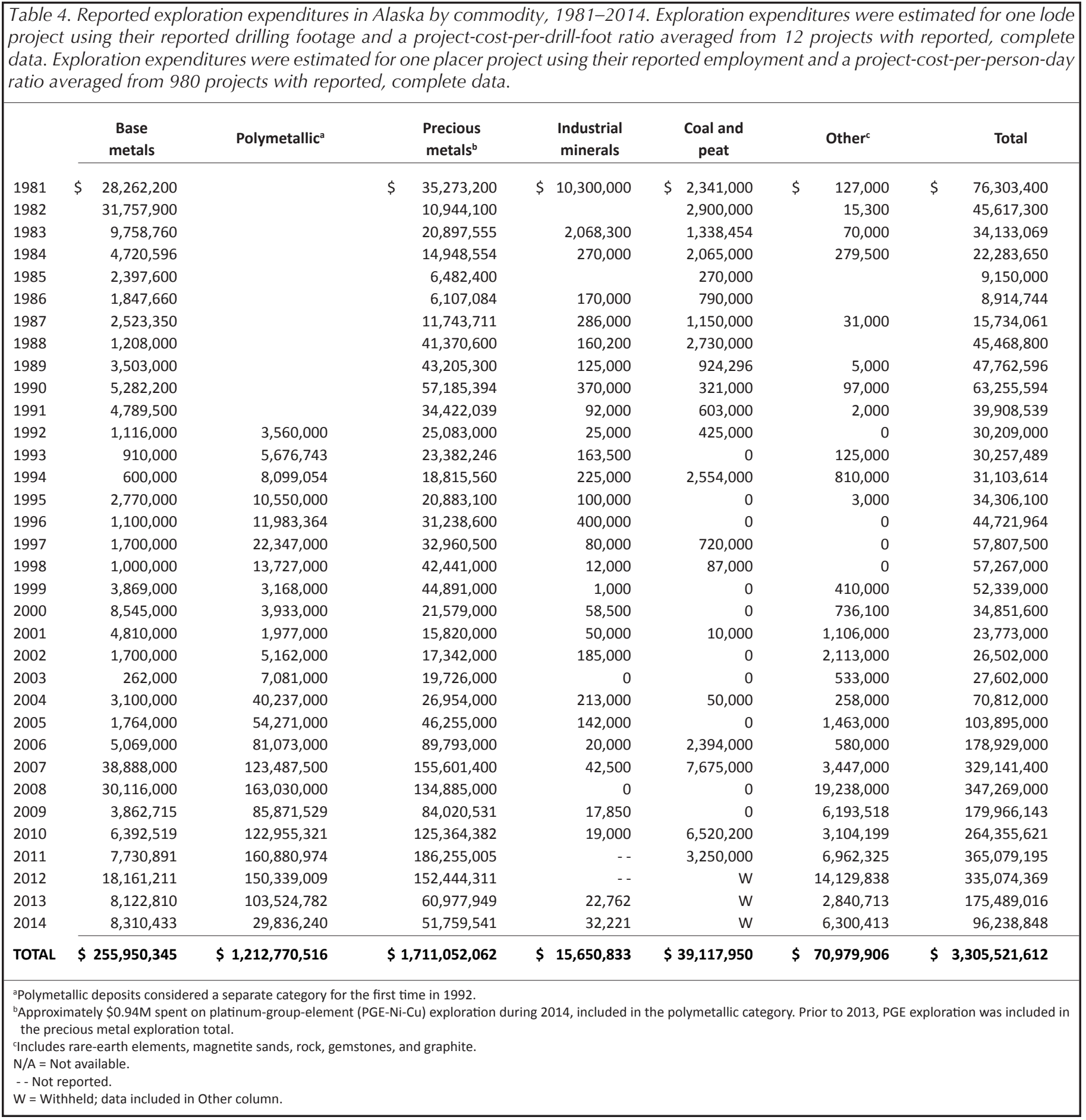




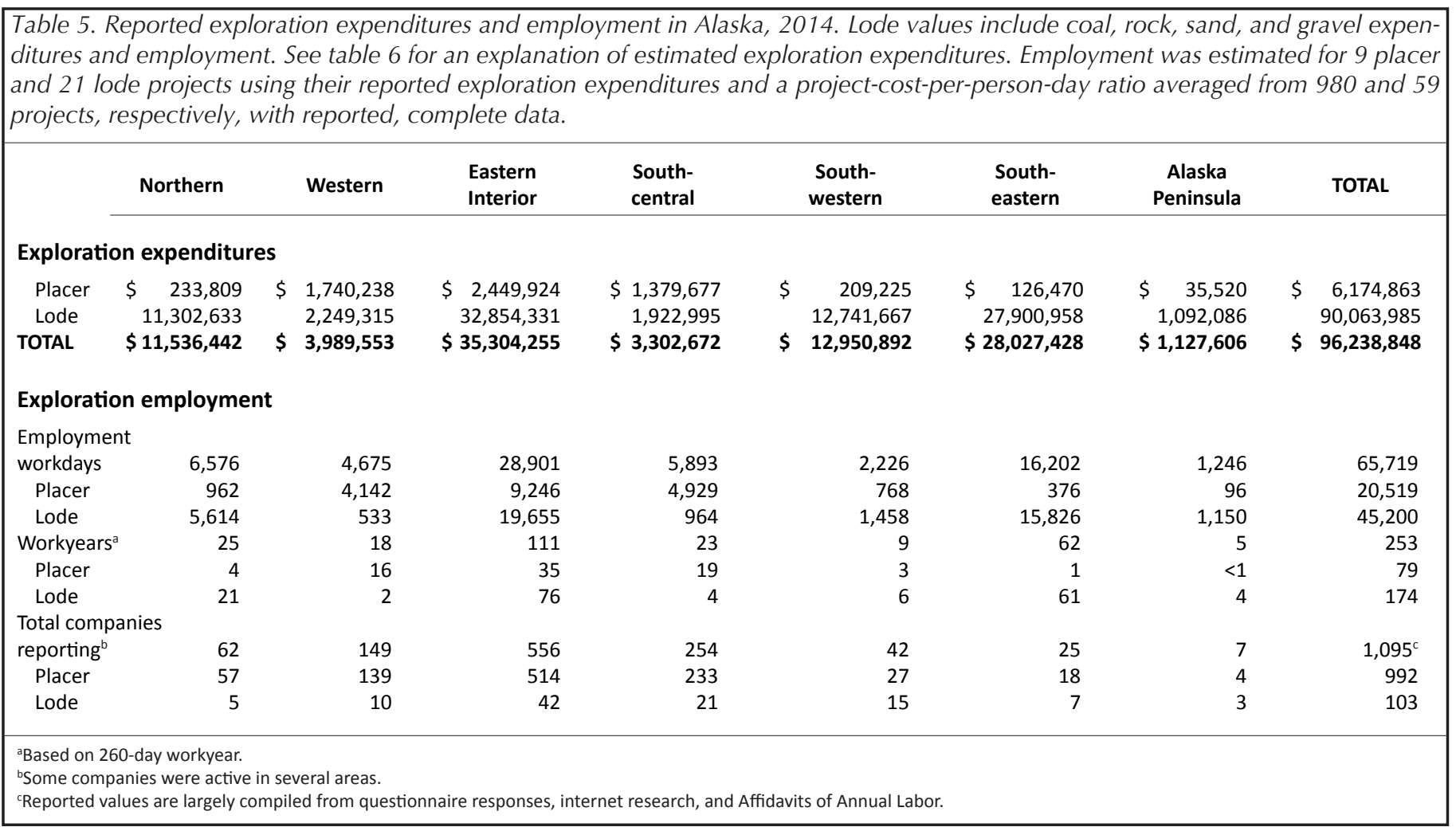

Placer exploration accounted for 6 percent of the exploration expenditures and 31 percent of the exploration employment statewide. A total of 992 placer operations, 212 more than in 2013, collectively reported exploration expenditures of $\$ 6.2$ million in 2014 , a decrease of 61 percent from the $\$ 16$ million spent in 2013. The decrease in placer expenditures is somewhat in line with the decrease in employment in the placer mine sector from 2013 to 2014; some of this decrease can be attributed to the declining gold price, some may be attributed to the record rainfall resulting in high water levels, and a part of this drop likely reflects changes in source data for this report. The Eastern Interior is the dominant region of the state for placer exploration, with 52 percent of the operators, 40 percent of the expenditures, and 45 percent of the employees in the placer sector. A $\$ 10.3$ million exploration expenditure decrease in the Western region is from lack of reported activity by two major mining companies in the offshore Nome lease area. Reporting of placer activity in the state is inconsistent, and year-to-year changes in placer exploration expenditures and employment statewide are as likely as much an artifact of reporting as of any significant trend. Thirty marine placer operations reported three full-time-equivalent positions dedicated to exploration.

Fifteen companies individually spent more than $\$ 1$ million on mineral exploration in the state for a combined total of

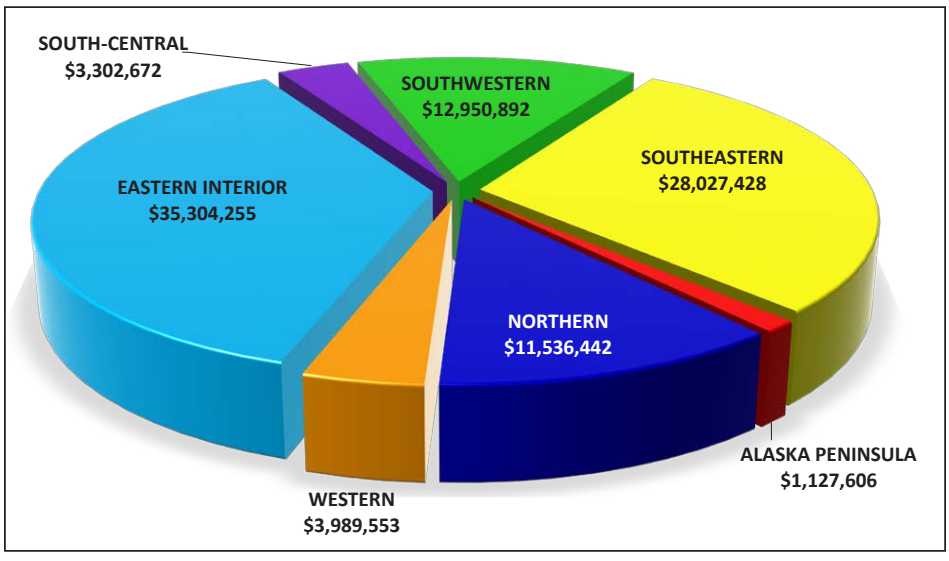

Figure 11. Exploration expenditures by region, 2014.

more than $\$ 81.1$ million (almost 84 percent of 2014 exploration expenditures and 59 percent of exploration employment); 28 additional companies spent more than $\$ 100,000$ each for a combined total of more than $\$ 9.2$ million (10 percent of 2014 exploration funds and 8 percent of exploration employment).

Seven advanced exploration projects ${ }^{14}$-Zazu's Lik, NovaCopper's Upper Kobuk Mineral Projects (Arctic and Bornite), International Tower Hill's Livengood, Northern Dynasty's Pebble, WestMountain's Terra, Heatherdale's Niblack, and Ucore's Bokan-accounted for 25 percent of the exploration expenditures in 2014 for a total of $\$ 24.1$ million. The Pebble

\footnotetext{
${ }^{14}$ We define advanced exploration projects as having met most or all of the following criteria: A completed Preliminary Economic Assessment; project focus has shifted from resource discovery to resource definition, engineering, and environmental work; the DNR Large Mine Permitting Team has been engaged; and AIDEA has been engaged in infrastructure studies.
} 
porphyry copper-gold project in the Southwestern region, one of the largest porphyry deposits in the world with identified resources of 81.8 billion pounds of copper, 107.9 million ounces of gold, and 5.8 billion pounds of molybdenum, is now wholly owned by Northern Dynasty Minerals Ltd., and was the largest exploration project (other than mine site exploration) in 2014. Metal resources for Pebble and the other major projects are tabulated in appendix $\mathrm{F}$ and described in the regional descriptions.

Operating mines in Alaska spent a combined total of more than $\$ 38.3$ million ( 40 percent of all exploration expenditures in the state) on exploration to identify additional resources and increase mine life. The 2014 exploration budget at Pogo mine was approximately $\$ 17$ million, the largest exploration program in the state.

Other significant 2014 exploration projects include Constantine Metal Resources' Palmer project in the Southeastern region, Graphite One Resources' Graphite Creek project in the Western region, and Freegold Ventures' Golden Summit project and Sumitomo's Stone Boy project in the Eastern Interior region.
Other notable projects are identified in figure 7 and described in regional exploration descriptions.

Table 6 summarizes the number of new and active (new plus existing) mining claims per year, from 1991 through 2014. State 40- and 160-acre claim staking decreased by 62 percent (in terms of area) in 2014, while staking of State prospecting sites decreased by 32 percent. Federal claim staking decreased by 76 percent. This downward trend in claim staking and in total acreage of active claims will likely continue as companies seek to reduce holding costs and consolidate property positions during the global market downturn.

The State's Airborne Geophysical/Geological Mineral Inventory (AGGMI) Program celebrated its 21 st year, with geophysical surveys to date covering 21,451 square miles (3.15 percent) of Alaska's land mass (table 7). DGGS also contracted a helicopter-borne geophysical survey for the 966 square mile Tok River area in the eastern Alaska Range, 200 miles northeast of Anchorage; the area has few documented mineral occurrences but prospective geology for volcanogenic massive sulfide, porphyry copper-gold, and orogenic gold veins.

\begin{tabular}{|c|c|c|c|c|c|c|c|c|}
\hline \multirow[b]{2}{*}{ Year $^{a}$} & \multicolumn{4}{|c|}{ State Claims } & \multicolumn{2}{|c|}{$\begin{array}{l}\text { State Prospecting Sites } \\
\text { (160 acres) }\end{array}$} & \multicolumn{2}{|c|}{$\begin{array}{l}\text { Federal Claims } \\
\text { (20 acre sites) }\end{array}$} \\
\hline & $\begin{array}{c}\text { New } \\
\text { (Active) } \\
40 \text { acre }^{b}\end{array}$ & $\begin{array}{c}\text { New } \\
\text { (Active) } \\
160 \text { acre }\end{array}$ & $\begin{array}{c}\text { Total } \\
\text { (Active) } \\
40 \text { acre }^{\mathrm{b}}\end{array}$ & $\begin{array}{c}\text { Total } \\
\text { (Active) } \\
160 \text { acre }\end{array}$ & New & Total & New & Total \\
\hline 1991 & 3,277 & 0 & 37,862 & 0 & 747 & 1,723 & 1,299 & 23,222 \\
\hline 1992 & 2,640 & 0 & 36,250 & 0 & 454 & 1,472 & 695 & 20,254 \\
\hline 1993 & 2,120 & 0 & 34,340 & 0 & 1,412 & 2,259 & 601 & 9,298 \\
\hline 1994 & 4,057 & 0 & 34,400 & 0 & 802 & 2,378 & 341 & 8,495 \\
\hline 1995 & 4,512 & 0 & 30,464 & 0 & 1,030 & 2,725 & 376 & 7,766 \\
\hline 1996 & 9,489 & 0 & 36,602 & 0 & 2,082 & 3,687 & 681 & 9,346 \\
\hline 1997 & 8,678 & 0 & 42,836 & 0 & 2,480 & 5,305 & 1,872 & 11,320 \\
\hline 1998 & 9,786 & 0 & 49,816 & 0 & 3,194 & 7,148 & 427 & 11,033 \\
\hline 1999 & 11,978 & 0 & 56,107 & 0 & 1,755 & 7,600 & 308 & 10,176 \\
\hline 2000 & 4,560 & 614 & 54,393 & 614 & 1,143 & 5,675 & 523 & 7,805 \\
\hline 2001 & 858 & 907 & 49,627 & 1,503 & 27 & 3,091 & 464 & 8,248 \\
\hline 2002 & 745 & 826 & 44,056 & 2,179 & 61 & 2,138 & 261 & 8,100 \\
\hline 2003 & 856 & 2,603 & 38,076 & 4,387 & 101 & 1,857 & 676 & 8,424 \\
\hline 2004 & 1,070 & 3,533 & 34,380 & 7,719 & 59 & 1,484 & 66 & 8,313 \\
\hline 2005 & 806 & 4,502 & 34,066 & 11,551 & 128 & 1,612 & 411 & 7,826 \\
\hline 2006 & 1,111 & 5,747 & 33,864 & 16,249 & 103 & 1,646 & 457 & 8,068 \\
\hline 2007 & 576 & 6,031 & 31,305 & 20,208 & 57 & 1,625 & 933 & 8,872 \\
\hline 2008 & 1,333 & 2,565 & 23,033 & 13,519 & 24 & 651 & 3,001 & 11,732 \\
\hline 2009 & 1,142 & 2,793 & 24,340 & 16,381 & 40 & 335 & 1,057 & 10,431 \\
\hline 2010 & 1,446 & 6,132 & 24,805 & 20,389 & 88 & 441 & 332 & 8,413 \\
\hline 2011 & 1,932 & 4,893 & 24,319 & 21,970 & 180 & 273 & 284 & 8,438 \\
\hline 2012 & 1,638 & 3,478 & 24,673 & 20,810 & 202 & 409 & 632 & -- \\
\hline 2013 & 1,622 & 2,155 & 24,883 & 17,347 & 28 & 209 & 289 & 6,916 \\
\hline 2014 & 1,219 & 677 & 25,479 & 15,250 & 19 & 197 & 69 & 6,003 \\
\hline \multicolumn{9}{|c|}{$\begin{array}{l}\text { Updated information provided by Jeff Jasper (DNR, Inf } \\
\text { Table has been reorganized to conform with compute } \\
\text { aAfter } 2010 \text {, State claim and prospecting site totals ar } \\
\text { Leasehold Locations whose claimants filed an Annu } \\
\text { claims on State-selected land in } 2014 \text {. } \\
\text { bIncludes claim fractions varying from } 1 \text { to } 39 \text { acres. } \\
\text { - - Not reported }\end{array}$} \\
\hline
\end{tabular}




\begin{tabular}{|c|c|c|}
\hline Survey Area & Survey Size & Resulting Products \\
\hline Nyac District core area & 183 sq. miles & Airborne aeromagnetic survey \\
\hline Circle District core area & 338 sq. miles & Airborne geophysical survey; geologic map \\
\hline Richardson District & 137 sq. miles & Airborne geophysical survey \\
\hline Rampart/Manley-Tofty & 1,017 sq. miles & Airborne geophysical survey; geologic map \\
\hline Upper Chulitna District & 364 sq. miles & Airborne geophysical survey; geologic map \\
\hline Petersville-Collinsville District & 415 sq. miles & Airborne geophysical survey; geologic map \\
\hline Iron Creek District & 689 sq. miles & Airborne geophysical survey; geologic map \\
\hline Salcha River/North Pogo & 1,032 sq. miles & Airborne geophysical survey; geologic maps \\
\hline Southeast extension of Salcha River-Pogo & 91 sq. miles & Airborne geophysical survey \\
\hline Liberty Bell & 276 sq. miles & Airborne geophysical survey; geologic map \\
\hline Broad Pass & 304 sq. miles & Airborne geophysical survey \\
\hline Council & 618 sq. miles & $\begin{array}{l}\text { Airborne geophysical survey; geologic map (field work } \\
\text { completed; partial preliminary map published, map in prep.) }\end{array}$ \\
\hline Goodpaster River & 210 sq. miles & $\begin{array}{l}\text { Airborne geophysical survey; geologic mapping (field work } \\
\text { completed; map in prep.) }\end{array}$ \\
\hline Liscumc & 67 sq. miles & Airborne geophysical survey \\
\hline Styx River ${ }^{\mathrm{e}}$ & 710 sq. miles & $\begin{array}{l}\text { Airborne geophysical survey; geologic mapping (field work } \\
\text { completed map in prep.) }\end{array}$ \\
\hline Slate Creek-Slana River & 442 sq. miles & $\begin{array}{l}\text { Airborne geophysical survey; geologic mapping (field work } \\
\text { completed; map in prep.) }\end{array}$ \\
\hline Moran & 653 sq. miles & $\begin{array}{l}\text { Airborne geophysical survey; geologic mapping (field work } \\
\text { completed; map in prep.) }\end{array}$ \\
\hline Ladue & 742 sq. miles & Airborne geophysical survey \\
\hline Iditarod & 852 sq. miles & Airborne geophysical survey \\
\hline $\begin{array}{l}\text { Dalzell Creek, Middle Styx, Southern Dishna } \\
\text { River, Fox Hills, and Beaver Creek }\end{array}$ & 1,294 sq. miles & Airborne geophysical survey; geologic mapping \\
\hline Farewell (includes contribution from CIRI) & 954 sq. miles & Airborne geophysical survey; geologic mapping \\
\hline Middle Styx & 138 sq. miles & Airborne geophysical survey \\
\hline $\begin{array}{l}\text { Wrangellia (includes } 12 \text { sq. miles from Millrock } \\
\text { Resources) }\end{array}$ & 1,322 sq. miles & $\begin{array}{l}\text { Airborne geophysical survey; geologic mapping (field work } \\
\text { in progress; map in prep.) }\end{array}$ \\
\hline East Styx & 1,052 sq. miles & Airborne geophysical survey \\
\hline 21 years \$17.1 million & 21,451 sq. miles & $3.15 \%$ of Alaska's total area \\
\hline \multicolumn{3}{|c|}{$\begin{array}{l}\text { aProjects funded by the Alaska State Legislature. Projects concentrate on State, Native, State-selected, and Native-selected lands, and are managed by DGGS. } \\
\text { 'DGGS published a geologic map of the Ruby-Poorman mining district based on mapping in } 1984 \text { by the Anaconda Minerals Co. } \\
\text { cProject funded through agreement with AngloGold Ashanti (USA) Exploration Inc. } \\
\text { dProject funded by the Alaska State Legislature as a \$2 million Capital Improvement Project to assess the geologic hazards and resource potential along the proposed natural gas pipeline } \\
\text { corridor between Delta Junction and the Canada border. } \\
\text { eProject partially funded through agreement with Anglo American Exploration (USA) Inc. under the DGGS Mineral Industry Sponsorship Program. } \\
\text { Note: Surveys listed above are complete except where noted. Additional areas will be scheduled for surveying at later dates contingent on future funding. }\end{array}$} \\
\hline
\end{tabular}


DGGS continued a multi-year project to study the western portion of the Wrangellia geologic belt using exploration geochemistry, geophysics, and targeted geologic mapping as part of the AGGMI/Strategic and Critical Minerals Assessment project, a State-funded Capital Improvement Project to evaluate Alaska's potential for strategic and critical minerals (SCMs). SCMs are essential for our modern, technology-based society, and include rare-earth elements, platinum-group elements, antimony, barium, chromium, cobalt, fluorine, gallium, graphite, indium, niobium, rhenium, tantalum, titanium, tungsten, and yttrium. The U.S. is more than 70 percent dependent on imports for 13 of these 16 critical elements and elemental groups, and 100 percent dependent on imports for seven. This leaves the U.S. vulnerable to disruptions in the SCM supply chain. As part of the Wrangellia study, DGGS conducted geologic mapping and minerals-related studies in 2014 in the Talkeetna Mountains C-4 Quadrangle in the western Alaska Range (photo 2) and in the Tonsina area in the northeastern Chugach Mountains. Data

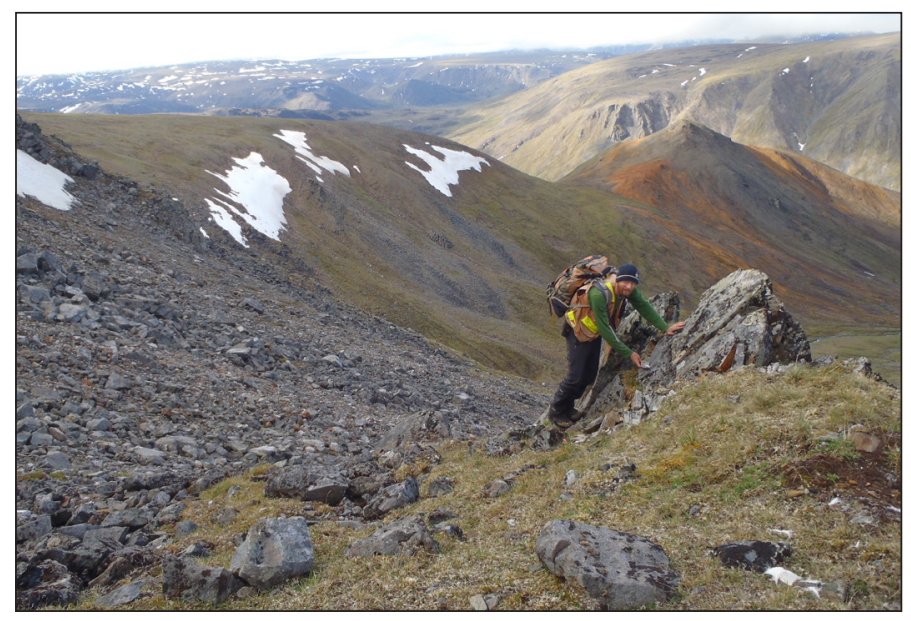

Photo 2. DGGS geologist Evan Twelker measuring a foliation surface in Paleozoic metasedimentary rocks in the Talkeetna Mountains C-4 Quadrangle. Photo by Karri Sicard, DGGS. and maps for a 1,322 square mile helicopter-borne geophysical survey in the Wrangellia area were released in 2014 as part of this study. An additional 269 square mile area was contracted in 2014 in the Tonsina area to investigate PGE prospects, and DGGS geologists conducted ground-truth geologic and mineral occurrence studies in support of the geophysical survey.

In addition to the Wrangellia survey, DGGS released airborne geophysical data for three surveys-Middle Styx, East Styx, and Farewell-in the western Alaska Range centered around Rainy Pass and near the Whistler porphyry-copper deposit in the South-central and Southwest regions. Summaries of mineral-related mapping products and geophysical surveys that have been completed, with both State and Federal funding, are provided in tables 7 and 8 . Released geologic maps, geophysical data, and Alaska minerals information can be found at http:// www.dggs.alaska.gov/and http://AKGeology.info. An online application provides an interactive interface for Alaska airborne geophysical data at http://dx.doi.org/10.14509/gp.

\section{NORTHERN REGION}

Mineral exploration expenditures in Alaska's Northern region were approximately $\$ 11.5$ million during 2014 . Primary targets of these expenditures were sedex-style zinc-lead-silver mineralization in the DeLong Mountains, copper-rich polymetallic carbonate replacement and volcanogenic massive-sulfide (VMS) mineralization in the upper Kobuk River area, and placer and lode gold in the Chandalar mining district.

Teck Alaska Inc. completed approximately 22,000 feet of exploration drilling on approximately 135 square miles of State of Alaska and NANA Regional Corp. land in the DeLong Mountains of northwestern Alaska. As of the end of 2014 Teck reported 58.2 million tons of proven and probable reserves at Red Dog Mine with an average grade of 16.5 percent zinc, 4.3 percent lead, and 2.34 ounces of silver per ton (appendix F). These reserves represent an increase in both tonnage and grades

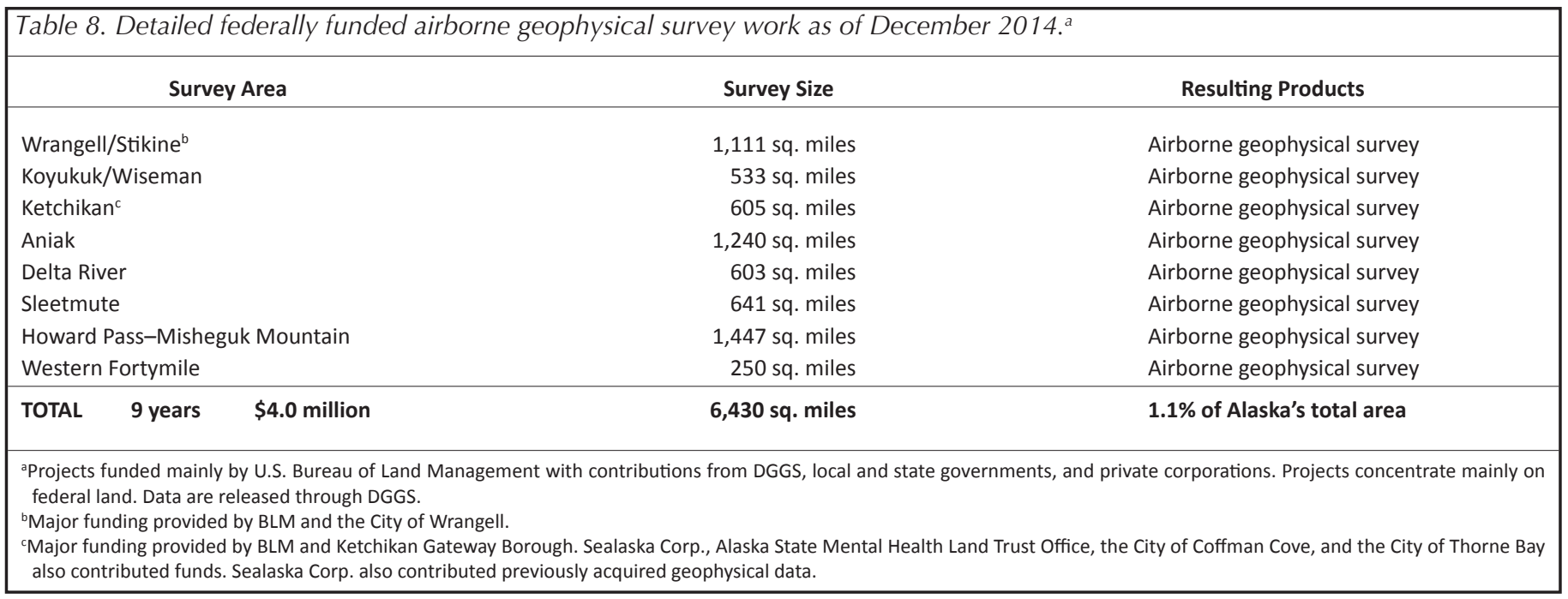


across the suite of metals, primarily the result of upgrading mineral resources to reserves at Qanaiyaq, a near-surface deposit to the south of the mined-out Red Dog Main deposit (photo 3). Qanaiyaq is now reported to encompass 8.16 million tons of probable reserves, averaging 24.7 percent zinc and 6.9 percent lead. Paalaaq, adjacent to the north of Aqqaluk pit, is a deeper deposit that also has the potential to add to reserves in the immediate Red Dog Mine area. In addition to exploring NANAowned lands immediately surrounding Red Dog Mine, Teck completed drilling at Noatak, a block of State claims bordering the west side of the Red Dog property. Anarraaq-Aktigiruq, roughly 8 miles northwest of Red Dog, is among the high-grade zinc-lead targets Teck is pursuing on the Noatak claims. Teck discovered the Anarraaq deposit in 1999, subsequently establishing an inferred resource of about 19 million tons grading 15.8 percent zinc, 4.8 percent lead, and 2.1 ounces of silver per ton but has not publicly released an update to this resource in recent years.

In April Zazu Metals Corp. released a preliminary economic assessment (PEA) for a mine at Lik, a sediment-hosted zinc project about 14 miles northwest of Red Dog Mine. Lik is divided into two deposits separated by a fault-the near-surface Lik South and the deeper Lik North. The total identified resource of the two separate deposits is 25.85 million tons containing 2.72 percent lead, 8.23 percent zinc, and 1.63 ounces of silver per ton (appendix F). The PEA envisions an open-pit mine with a 9-year mine life, producing 18.85 million tons of massive-sulfide ore averaging 7.7 percent zinc, 2.6 percent lead, and 1.37 ounces of silver per ton from the Lik South deposit. The ore would be milled at a 6,060-ton-per-day rate, producing 319,500 dry tons of zinc and lead concentrates containing 273 million pounds of zinc and 75 million pounds of lead per year. In addition to the PEA, Zazu's 2014 program included continued metallurgical work, refinements to the mine design, acid rock drainage characterization studies, and environmental work. Under an MOU with Zazu, AIDEA conducted a review of the PEA, future commodity prices, and road and port analysis of the current DeLong Mountain Transportation System (DMTS) in a feasibility study for expanding the DMTS to accommodate additional concentrate from the Lik deposit.

In April Millrock Resources Inc. staked Lisburne, a grassroots zinc prospect approximately 90 miles northwest of Red Dog. Situated on the coast of the Chukchi Sea about 12 miles south of Cape Lisburne, the 13,100 acres of State mining claims that make up the Lisburne property blanket a region dominated by carbonate rocks of the Mississippian Lisburne Formation, which host the zinc deposits in the Red Dog area. Streamsediment samples collected by the USGS indicate strong zinc and barium anomalies on the claims. Millrock said regional and detailed geologic mapping is the first order of business for this grassroots zinc prospect.

NovaCopper Inc. invested \$2.7 million on exploration at the Upper Kobuk Minerals Project during 2014. The Upper Kobuk Minerals Project (UKMP), in the Ambler mining district, is a partnership that joins NovaCopper's Ambler property with copper-prospective lands owned by NANA Corp. The 112,058 acres of State, Federal, and patented mining claims that make up the Ambler portion of UKMP feature the Arctic volcanogenic massive-sulfide deposit and a number of other similar deposits and prospects stretching approximately 70 miles along

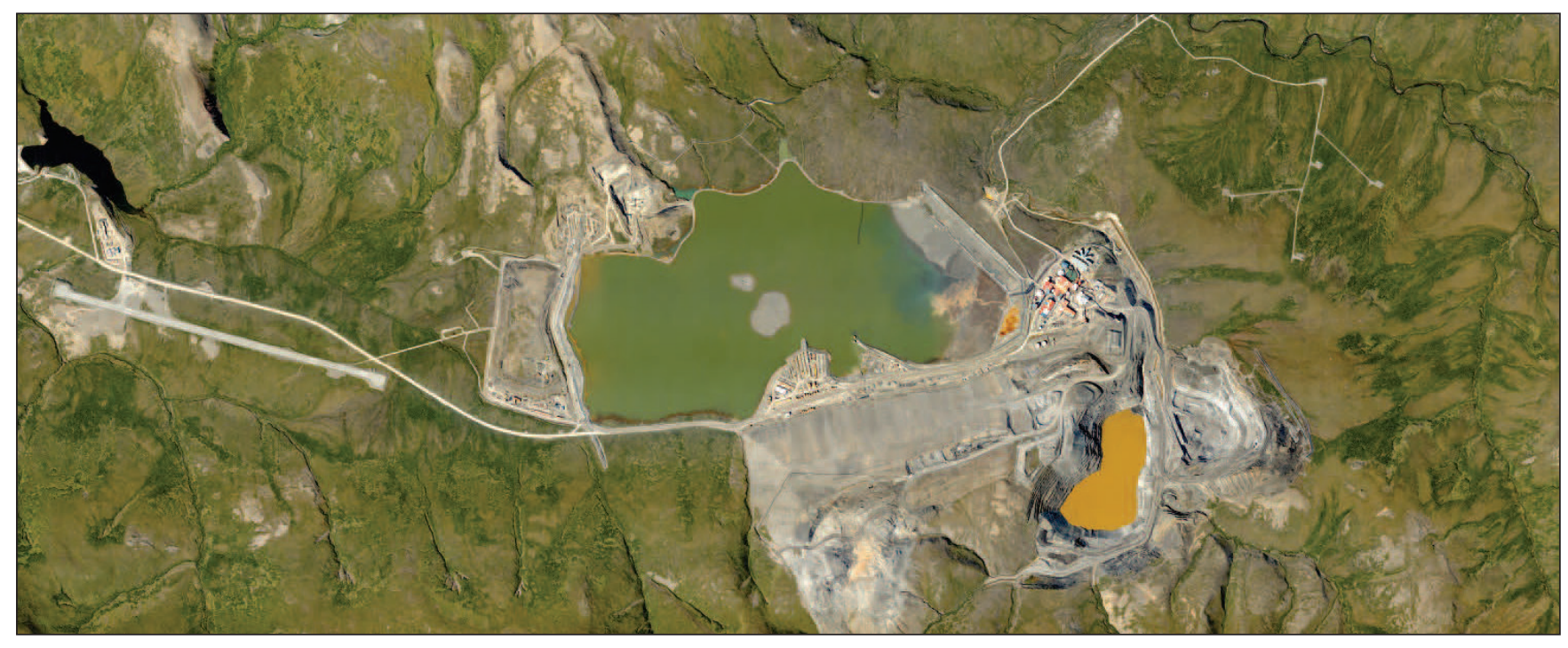

Photo 3. Aerial photo of Red Dog Mine in 2014; north is toward the top of photo. The tailings storage facility is in the photo's center. The Qanaiyaq deposit is just south of the active mine area, just to right of center-bottom of photo. The Aqqaluk deposit, at the southeast corner of the mineralized area, is currently being mined using open-pit methods. Photo from Teck Zinc Business Unit presentation, March 31, 2015; posted on Teck Resources Ltd. website. 
the southern slopes of the Brooks Range. The 240,885 acres of NANA lands, which lie immediately to the south of the Ambler portion, feature Bornite and a number of carbonate-hosted copper prospects. In March NovaCopper provided an updated resource, based on 2011-2013 drilling and some historical Kennecott core holes, which increased the contained copper at Bornite by 2.56 billion pounds to a total identified resource of 6.03 billion pounds of copper in 197.6 million tons of ore averaging 1.53 percent copper (appendix F).

For its 2014 exploration program NovaCopper relogged approximately 42,650 feet of historical core from 37 holes in the near-surface Ruby Creek zone of the Bornite deposit that Kennecott Copper Co. drilled between 1957 and 1975. Of the holes resampled, NovaCopper reports that five had intervals grading more than 0.5 percent copper, and 21 contained mineralization grading more than 0.2 percent copper. The company anticipates this program will add lower-grade material in the previously calculated pit shell and Bornite near-surface resource.

In addition to conducting the Bornite resampling program, NovaCopper continued environmental sampling, community engagement, and supporting the Alaska Industrial Development and Export Authority (AIDEA) in initiating the permitting process on the Ambler Mining District Industrial Access Road, a 211-mile-long road extending west from the Dalton Highway to the project area. The Arctic volcanogenic massive-sulfide deposit, about 16 miles northeast of Bornite, is the most advanced of the UKMP prospects. A 2013 preliminary economic assessment was completed for an 11,000-ton-per-day open-pit mine at Arctic with an anticipated 12-year mine life, which would produce 1.56 billion pounds of copper, 2.13 billion pounds of zinc, 309 million pounds of lead, 34.0 million ounces of silver, and 369,000 ounces of gold over the life of the mine. Subject to financing, NovaCopper plans to complete additional drilling and other work at Arctic during 2015 toward completing a feasibility study for Arctic within the next 3 years, assess the viability of mining at Bornite, and evaluate synergies between the two prospects.

Goldrich Mining Co. expended an estimated \$277,000 on the continued exploration of lode gold mineralization at its Chandalar property. This work included airborne magnetic and radiometric studies across the entire 22,850 acre property. Goldrich said these geophysical studies show a potassium-thorium anomaly that is associated with magnetic anomalies that form a large, circular feature in the highlands above the Chandalar placer deposits, which is consistent with an intrusive body at depth and is central to a trend of lode quartz-gold occurrences. Goldrich also completed a petrologic study that involved detailed microprobe examination of samples taken from veins in the Chandalar gold system, which exhibit characteristics of pegmatite, an igneous rock formed during emplacement of a granitic intrusive body. The company said all of the samples contain numerous accessory minerals that are commonly derived from magma or late-stage magmatic fluids, including monazite, thorite, and xenotime. The company believes follow-up rock sampling and radiogenic surveys could help prioritize drill targets across the expansive Chandalar property.

At least 57 individuals and companies completed placer gold exploration, representing more than $\$ 200,000$ of spending, in the Northern region during 2014.

\section{WESTERN REGION}

Gold and graphite were the primary targets of nearly $\$ 4$ million spent on exploration conducted in Alaska's Western region during 2014.

Graphite One Resources Inc. invested \$1.63 million on exploration at its Graphite Creek property on Alaska's Seward Peninsula during 2014. This work included infill drilling to upgrade a portion of the inferred resource at Graphite Creek, and metallurgical studies. Previously the company drilled 28 holes, resulting in an inferred resource of 206.0 million tons grading 5.5 percent graphite. The current deposit represents drilling along less than 30 percent of an 11.2-mile-long conductor zone revealed by a 2012 airborne magnetic and electromagnetic (EM) survey; the identified resource closely correlates with the EM conductor and graphite in the ground (photo 4). The 20-hole drill program that began in August 2014 targeted a 2,300-foot-long section of the deposit where previous nearsurface intercepts of up to 165 feet of 10 percent graphite had been encountered. The best 2014 intercept contained 9.74 percent graphite over a near-true-thickness of 140.5 feet, and included a 23.1 foot section containing 20.89 percent graphite (table 9). Highlights from 2014 drilling are reported in table 9. An upgraded resource scheduled to be completed by mid 2015 will be used to inform a preliminary economic assessment. In April the company reported that metallurgical tests, leach process following flotation, on samples from Graphite Creek have returned product grades topping 99.9 percent carbon. Graphite One's 2014 field program included the collection of mini bulk samples from the surface and drill core, which can be used to continue the development and simplification of a process to produce graphite of the purity required for lithium-ion batteries and other applications. The Graphite Creek property is about 40 miles north of Nome and about 24 miles east of Port Clarence; both are among many sites being considered for an Arctic deep-water port by the U.S. Army Corps of Engineers.

NANA Regional Corp. completed more than $\$ 400,000$ of exploration on two blocks of State of Alaska mining claims in the Candle mining district in the Western region. This work included mapping and sampling of a gold prospect approximately 7 miles southwest of Candle in preparation for drilling planned for 2015. 


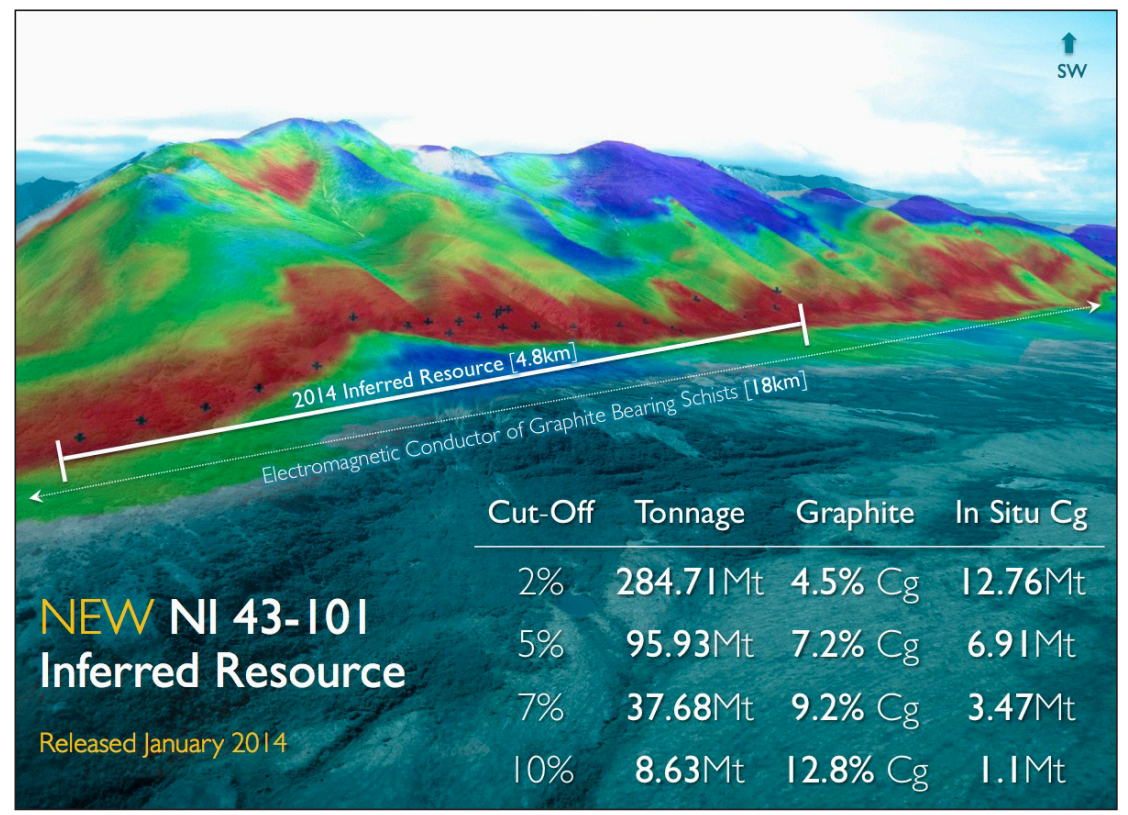

Photo 4. Image showing apparent conductivity draped over the topography of the northern Kigluaik Mountains, Seward Peninsula. The area marked with white bar represents higher conductivity, which outlines the trend of graphite-bearing rocks. The image shows the footprint of the inferred graphite resource at Graphite Creek. Image from Graphite One Resources website.

More than $\$ 1.7$ million was invested in placer gold exploration in the Western region during 2014. This work included more than 100 companies and individuals expending almost $\$ 1.5$ million on exploration of traditional onshore alluvial deposits and about 30 companies and individuals exploring for marine placer gold on offshore leases and claims extending for approximately 70 miles along the southern coast of the Seward Peninsula.

\section{EASTERN INTERIOR REGION}

Mineral exploration expenditures in 2014 in the Eastern Interior region were approximately $\$ 35$ million. The primary exploration targets in the region are gold with significant by- product copper, silver, cobalt, and antimony and polymetallic copper-lead-zinc-gold-silver deposits; gold and rare-earth-element (REE) alluvial deposits with significant byproduct copper, silver, cobalt, and antimony are also being explored.

Nearly half of the exploration expenditures in Eastern Interior were by Sumitomo Metal Mining Pogo (SMM Pogo) LLC, a joint venture between Japanese firms Sumitomo Metal Mining Co. (85 percent) and Sumitomo Corp. (15 percent), on expansion of gold deposits and prospects at the Pogo Gold Mine property near Delta Junction. The $\$ 17$ million program at Pogo primarily focused on expanding East Deep, North Zone, and South Pogo, three zones of high-grade gold mineralization adjacent to the Liese zone. Since the start of production in 2006 and until 2011 the Liese zone, three moderatedipping, subparallel, gold-bearing quartz veins, comprised the sole resource at Pogo. Subsequent to discovery in 2011, SMM Pogo identified significant resources in the East Deep and North Zone veins, enabling exploration resource expansion and reserve definition to keep pace with mine production. Geological and metallurgical evidence indicate that Liese and East Deep zones formed as a continuous set of veins, but were offset and split by a post-mineralization, 95-million-year-old diorite. The narrower, near-vertical, higher-grade North Zone veins immediately north of the Liese zone are believed to be feeders to the Liese and East Deep zones. Roughly $\$ 5$ million was spent on two drifts from the underground workings at East Deep to the North Zone (photo 5) to provide drill stations to more effectively drill the North Zone and enable continued northwestern expansion of

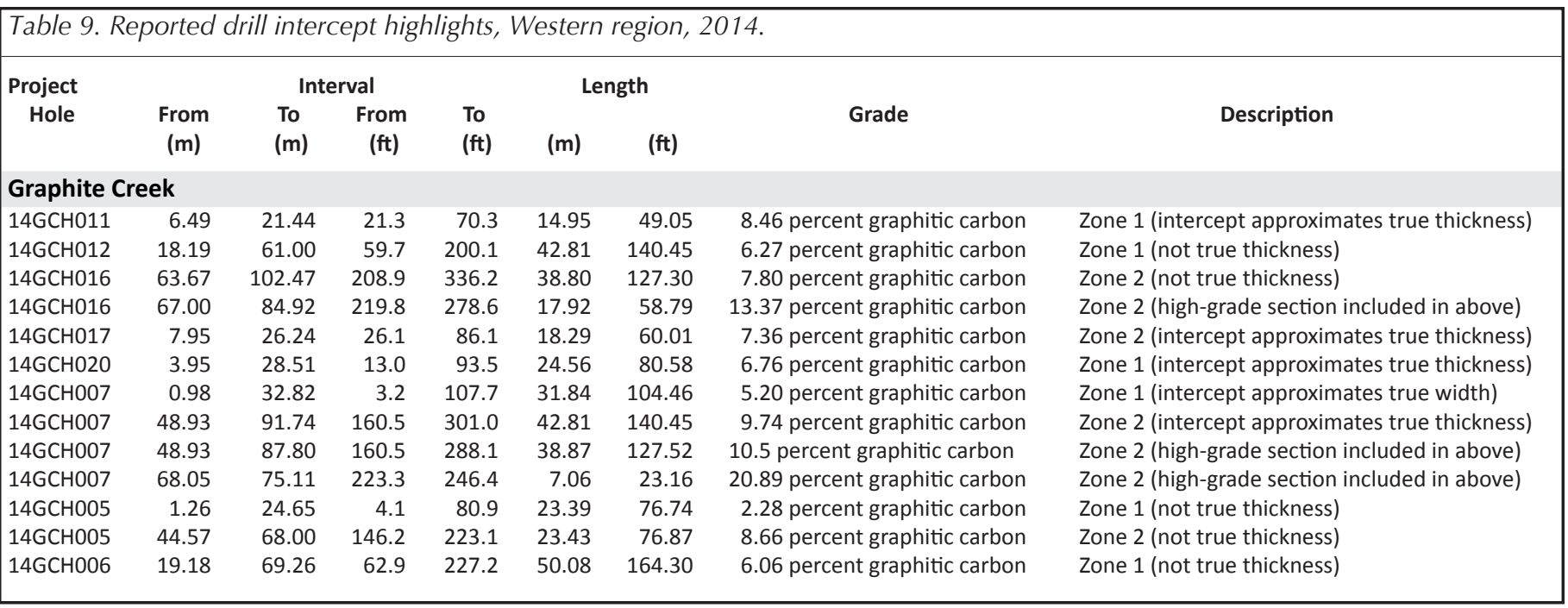


Photo 5. Jumbo rock-drilling machine drilling a blasthole pattern to advance an underground drift at Pogo Mine. Pogo spent \$5 million to advance underground exploration workings and access new drill stations in 2014. Photo from Pogo Mine annual presentation to the Alaska Large Mine Permitting Team, posted on State of Alaska, Department of Natural Resources, Large Mine Permitting website.

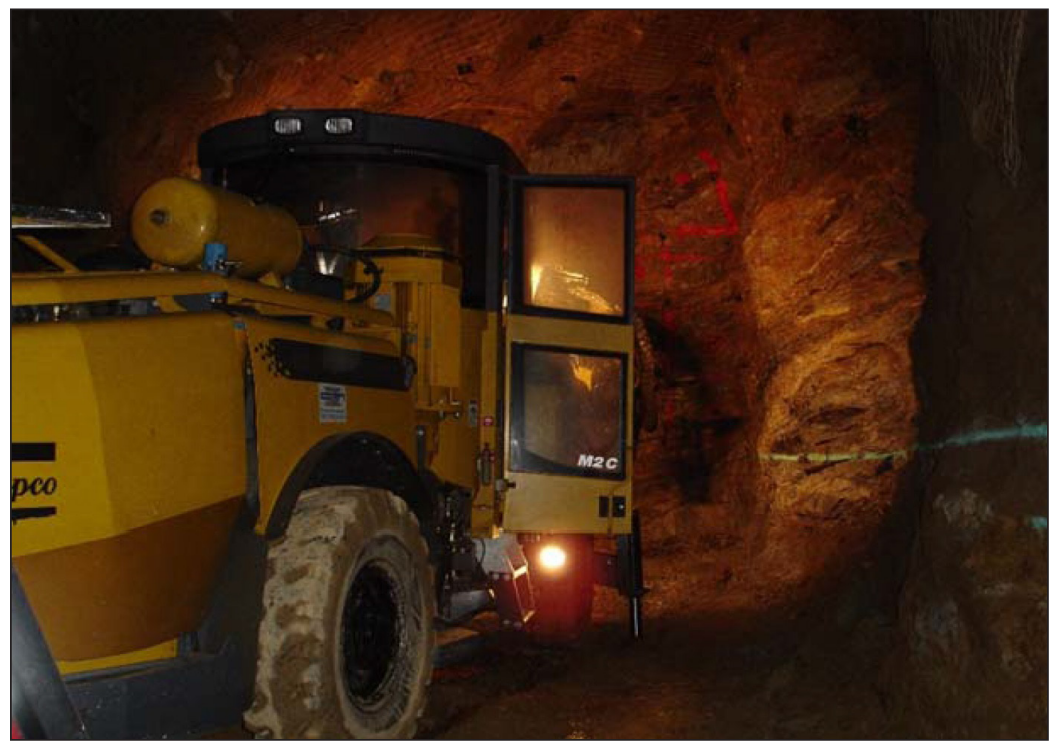

the East Deep zone. One underground drill and two surface rigs were used to explore Pogo South, a target immediately south of the Liese zone. Drilling at Pogo South has defined three separate veins that appear to be southerly extensions of the Liese zone veins. Surface exploration was also completed at the 4021 Zone, a deposit roughly 2.5 miles southeast of Liese. SMM Pogo geologists believe that if movement along a set of northeast-trending, post-mineralization faults is restored, the 4021 Zone would be on strike with the Liese zone. If true, this opens up the prospect of gold mineralization between these two known zones.

Stone Boy project partners Sumitomo Metal Mining Co. Ltd. (95 percent) and Sumitomo Corp. (5 percent) invested approximately $\$ 1.3$ million on continued exploration at the Ink claims, approximately 20 miles southeast of Pogo Mine. This exploration, carried out by Pathfinder Mineral Services, included 9,261 feet of drilling in six holes. A total of 910 core samples were submitted for analysis. Pathfinder reports that the results indicate the presence of gold and pathfinder-element mineralization associated with sheeted quartz veins cutting fine-grained diorite intrusive rocks. The 2014 program also included the analysis of 226 soil and 12 rock samples gathered during a fall geochemical survey. A LiDAR mapping survey was also carried out over the entire Ink claim group.

Corvus Gold Inc. published an inaugural mineral resource for its LMS gold property in October. Located about 24 miles southwest of Pogo, LMS was discovered by AngloGold Ashanti in 2006. Exploration by AngloGold Ashanti, Corvus, and a previous partner discovered gold in a stratiform breccia horizon as well as high-grade veins (photo 6). The inferred resource of 9.17 million tons at 0.029 ounce per ton gold contains 267,000 ounces and is based on the results from 11 holes drilled between 2005 and 2011. The resource is hosted in the breccia horizon and does not reflect the high-grade potential of the deeper vein gold.

Agnico Eagle Mines Ltd. carried out a $\$ 228,000$ exploration program at its Delta project about 80 miles south-southeast of Pogo. This work included logging core from historical drilling at the volcanogenic massive-sulfide district as well 3-D modeling and surface sampling. The Delta massive-sulfide belt has an inferred resource of 18.8 million tons (appendix F) in several massive-sulfide bodies. Agnico Eagle acquired Delta as part of its buyout of Grayd Resources Corp. in 2011.

Contango ORE Inc. consolidated positive results from 2011-13 drilling at its Tetlin gold-copper project near the cross-

Photo 6. Visible gold in dog-tooth quartz vein in core from the $L M S$ deposit northeast of Delta Junction in the Goodpaster mining district, Alaska. Photo from a technical report on the LMS gold project prepared by Ed Hunter and Garry Giroux for Corvus Gold Inc., Vancouver, B.C.; posted on Corvus Gold Ltd website.

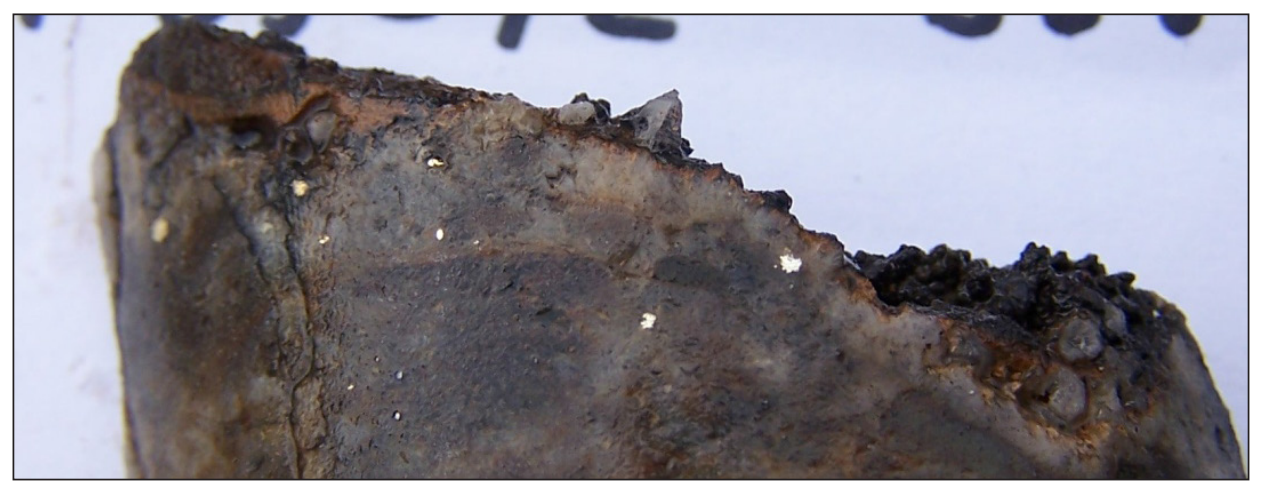


roads community of Tok during 2014 . The roughly $760,000-$ acre Tetlin property includes approximately 676,200 acres leased from the Tetlin Village Council and 83,720 acres of adjoining State of Alaska mining claims. In January Contango published an inaugural resource for the Peak Zone, on the Tetlin lease, which comprises a total identified resource of 10.82 million tons averaging 0.851 ounce of gold per ton. The Peak Zone is a polymetallic skarn and has significant credits of copper and silver, resulting in a contained 1.118 million gold-equivalentounce identified resource, of which 70 percent is in the identified resource category. In May Contango ORE announced results from preliminary metallurgical tests conducted on drill core samples from the Peak Zone, which demonstrated that gold and sulfide minerals respond to a combination of standard gravity and froth flotation for a gold recovery of 93-95 percent. The testing further indicates the gold is not refractory in nature. In September Contango ORE entered into a joint-venture agreement with Royal Gold Inc. to continue exploration and potential development at Tetlin. Under the terms of the agreement, Royal Gold can earn up to a 40 percent joint-venture interest in Tetlin by investing $\$ 30$ million by October 2018, including $\$ 5$ million in 2015.

Fairbanks Gold Mining Inc., a subsidiary of Kinross Gold Corp., expended \$7.6 million on exploration at its open-pit, intrusion-hosted Fort Knox Mine about 20 miles north of Fairbanks, and surrounding properties. This included 13,773 feet of core drilling and 8,952 feet of reverse-circulation drilling at the immediate Fort Knox property as well as 4,352 feet of core drilling at the adjacent Gil property. In addition to exploration drilling, Fairbanks Gold Mining completed five geotechnical holes, geologic mapping, engineering testing, and metallurgical work at Gil in 2014.

Fairbanks Gold Mining Inc. also completed trench, rock, and soil sampling programs at its $\mathrm{PB}$ and NPB claims as well as other nearby claims in the Circle mining district, roughly 80 miles northeast of Fort Knox, in 2014.

Freegold Ventures Ltd. carried out exploration at two Eastern Interior properties in 2014: the Golden Summit project just north of Fort Knox and the Shorty Creek copper-gold project about 1 mile south of Livengood.

Freegold Ventures continued advancing the Golden Summit property during 2014 by conducting metallurgical studies and initiating a Preliminary Environmental Assessment (PEA). To date, Freegold has a total identified resource of 361 million tons averaging 0.018 ounce of gold per ton and containing 6.53 million ounces of gold in the Dolphin Zone and in near-surface Dolphin/Cleary oxide material (appendix F). Bottle roll tests on a range of materials and a subsequent column leach test of coarse crushed oxide material suggest that gold recoveries in the range of 80-88 percent are possible for the oxide cap, but recoveries of transitional, hornfels-sulfide, and intrusion-hosted mineralization are as low as 45 percent. In January Freegold signed a memorandum of understanding with the Alaska Department of Natural Resources for engagement with the state's Large Mine Permitting Team, which the company says is the next logical step in ensuring the orderly development of Golden Summit. The company also acquired 1,440 acres of ground adjacent to Golden Summit, which covers the Coffee Dome prospect. Freegold said its reinterpretation of the airborne magnetics over the area, coupled with the presence of high-grade gold values with anomalous arsenic, antimony, bismuth, and tellurium suggest Coffee Dome is prospective for an intrusion-related gold system. Other 2014 work at Golden Summit includes ongoing environmental baseline studies, cultural resource work, and geochemical sampling.

Freegold Ventures acquired the Shorty Creek property in July 2014. Previous exploration at Shorty Creek has identified gold, copper, and pathfinder elements associated with gold-copper porphyry-style mineralization in limited shallow drilling. After acquiring Shorty Creek, Freegold completed an induced polarization (IP) survey, collected 354 soil samples, and staked 5,200 acres of additional claims, increasing the project area to 20,920 acres. The company said this program, along with historical work, defined significant IP chargeability anomalies with coincident anomalous copper, gold, molybdenum, and bismuth geochemistry. Freegold reported that in addition to the coincident geophysical and geochemical anomalies, widespread alteration and hornfels metamorphism spatially associated with small bodies of biotite granodiorite, quartz porphyry, and aplite are mapped over an extensive IP chargeability anomaly. The company believes the Shorty Creek project represents a drillready porphyry copper-gold target.

International Tower Hill Mines Ltd. spent \$2.3 million on the continued evaluation of Livengood, an advancedexploration-stage gold project about 75 road miles northwest of Fairbanks. The 2014 program included metallurgical work, mine production scheduling studies, power supply alternatives review, and alternative camp reviews. The company says these optimization studies have developed an improved production schedule compared to a feasibility study completed for Livengood in 2013. Optimization and environmental baseline studies will continue in 2015 .

Doyon Limited completed geophysical surveys at three projects on its lands in Interior Alaska during 2014. This work included IP surveys covering seven porphyry copper-gold targets at Northway, alongside the Alaska Highway near the Canada border. Doyon completed a similar program at its LWM zinclead-silver prospect in the Fortymile mining district. Doyon's 2014 fieldwork also included an airborne radiometric survey over a rare-earth-element (REE) prospect at the Sithylemenkat project about 125 miles northwest of Fairbanks. 
Endurance Gold Corp. completed a small reconnaissance prospecting and soil sampling program at its Elephant Mountain property approximately 45 miles southwest of Livengood. The property was previously explored by Placer Dome Inc., culminating in ten holes drilled in 1992. Endurance Gold says that their 2013 and 2014 work confirmed an intrusive-hosted target approximately 1 mile by 0.5 mile defined by two goldarsenic soil and rock sample anomalies that flank an untested IP chargeability anomaly.

Ucore Rare Metals Inc. completed a modest exploration program at its Ray River project about 120 miles northwest of Fairbanks. Alluvial deposits at Ray River contain elevated REE, tin, niobium, tantalum, and tungsten. Analyses of gravity-concentrate samples have returned up to 50 percent tin, 10 percent total REE, and 0.01-1 percent tungsten, tantalum, and niobium. Heavy rare earths_-including terbium, dysprosium, erbium, and yttrium-make up 15-25 percent of the total REE content in the majority of samples. The company said most of the initial samples were collected directly from surface exposures, and the heavy mineral content can be expected to increase at greater depths in the alluvium. In some areas the gravels are reported to be as deep as 100 meters.

More than 500 individuals and companies reported placer gold exploration in the Eastern Interior region. Together, this exploration accounted for approximately $\$ 2.4$ million in spending on projects ranging from small pan-prospecting programs on individual claims to drilling and bulk sampling in preparation for placer mining operations.

\section{SOUTH-CENTRAL REGION}

Gold, copper, and nickel were the primary targets of approximately $\$ 3.3$ million of mineral exploration completed in the South-central region during 2014.

During 2014 Kiska Metals Corp. published exploration summaries for their Whistler and Copper Joe porphyry copper-gold properties in the western Alaska Range, approximately 95 miles northwest of Anchorage. The larger Whistler property encompasses Whistler Orbit and Island Mountain, two main areas of porphyry mineralization, and Muddy Creek, an area prospective for intrusive-related gold. The property is anchored by the Whistler Deposit, which has an identified resource of 248 million tons at 0.16 percent copper, 0.013 ounce of gold per ton, and 0.053 ounce of silver per ton (appendix F). Kiska's 2014 program for Whistler consisted primarily of drill data validation and geologic modeling.

Late in 2014 Kiska Metals drilled two holes at Copper Joe, an earlier-stage project about 20 miles southeast of Whistler, as an initial test of coincident geochemical, IP (induced polarization), and airborne magnetic and electromagnetic anomalies. This 2,903-foot program was funded by First Quantum Minerals
Ltd. as part of an agreement to secure an exclusive right to enter into an option on Copper Joe. In December Kiska reported that the drilling did not return any significant assay results, but confirmed the presence of a strong porphyry-style alteration. DGGS published geochronological data that suggest that the porphyry style-alteration is about 10 million years old, one of the younger porphyry systems in the Alaska Range (photo 7). Kiska and First Quantum said they planned to carry out an alteration and mineral chemistry study of rocks from surface and drill core to further evaluate the property and potentially identify vectors toward the core of the porphyry system. First Quantum is planning to complete geophysical surveys at Copper Joe in 2015.

MMG USA Exploration LLC, a subsidiary of Melbourne, Australia-based MMG Ltd., continued exploration of its Nikolai nickel project in the South-central region. The company's 2014 field program included geologic mapping and one hole drilled at the Butte property, about 40 miles southwest of Pure Nickel's MAN nickel-platinum-group-element property.

In April Pure Nickel Inc. reported results of a nickel deportment study on 2013 drill core from its MAN nickel-PGE property in the southern Alaska Range, near Cantwell, Alaska. The study was conducted on a 415 foot intercept of the Eureka Zone in drill-hole PNI13-069 that contained 150 ppb palladium, 0.12 percent copper, and 0.28 percent nickel. The study found that 75.3 percent of the nickel occurs in potentially recoverable sulfide minerals and in nickel-iron alloys rather than in refractory silicate minerals. Pure Nickel reported no physical work on the project site in 2014 .

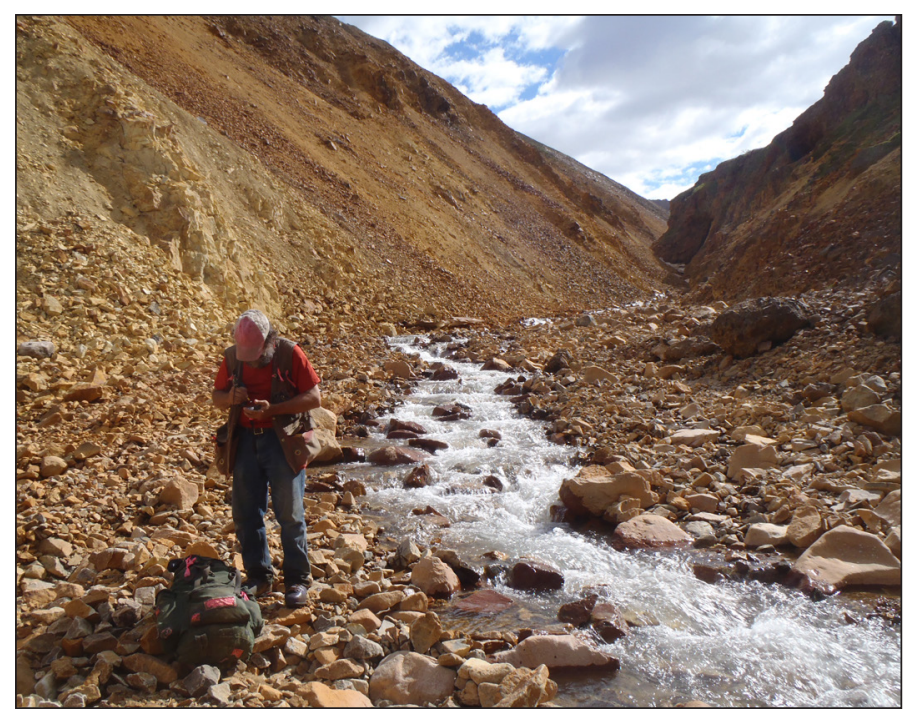

Photo 7. Rainer Newberry, of the University of Alaska Fairbanks, recording a description of approximately 10-million-year-old molybdenite-bearing veinlets from an extensive quartz-sericitepyrite alteration zone at the Copper Joe porphyry copper-goldmolybdenum prospect. Photo by Larry Freeman, DGGS. 
Miranda Gold Corp. worked toward confirming and expanding high-grade gold resources in advance of re-establishing an underground mine at the historical Willow Creek gold project, formerly known as the Lucky Shot and War Baby mines. In September, based on assays from 132 holes drilled from 2005 to 2009, Miranda published an initial resource estimate for the Coleman deposit, one segment of the Lucky Shot vein system. The total indicated resource is 92,600 tons containing 66,200 ounces gold. The company says that this initial upper Coleman resource is important, as it indicates that mineralization extends updip from the mine depths of historical production. Production from the Coleman, Lucky Shot, and War Baby mines came from faulted segments of the same vein, and each potential updip and downdip from historical workings. Similarly, soil and rock sampling completed in 2014 suggest that the vein system mined on Bullion Mountain, 1.9 miles east of Coleman, may extend beyond a fault that bounded historical production. The sampling identified a 2,600-foot-long gold-in-soil anomaly and identified three quartz vein subcrops that assayed 1.48 ounces per ton, 0.50 ounce per ton, and 0.53 ounce per ton gold. The Gold Bullion Mine is reported to have had historical production of 77,000 ounces at 1.4 ounces of gold per ton. In November Miranda entered into a joint-venture agreement with Gold Torrent Inc. to advance Willow Creek toward production. Gold Torrent plans to complete a feasibility study in 2015 that evaluates the potential for a gravity recovery operation at the high-grade gold project about 75 miles north of Anchorage.

Diamond Gold Corp. continued gemstone exploration at its Sable Elegance Mine project in the Kahiltna River region of South-central Alaska. The work focused primarily on the expansion of the Impact Creek tourmaline-pegmatite anomaly. The company reported that it recovered pink sapphire crystals and tourmaline from mica-rich pegmatite float collected from the roughly 1-mile-long, oval-shaped anomaly.

More than 200 individuals and companies reported placer gold exploration in South-central Alaska. Together, this accounted for more than $\$ 1$ million of spending on projects ranging from small pan-prospecting programs on individual claims to bulk sampling in preparation for placer mining operations. The largest such endeavor was carried out by Yakataga Mining Co., which conducted test mining of beach placers at its Cape Yakataga properties on the Gulf of Alaska.

\section{SOUTHWESTERN REGION}

At approximately $\$ 13$ million, 2014 exploration investment in the Southwestern region was down significantly compared to previous years. This drop is largely attributable to a substantial decrease in expenditures at the Pebble project.

The Pebble Limited Partnership's sole remaining partner, Northern Dynasty Ltd., expended approximately $\$ 11.21$ million on the continued evaluation of the Pebble copper-gold-molybdenum project during 2014. As part of its overall review of Pebble, the company commissioned a technical report that includes an updated resource that indicates it is the largest undeveloped identified resource of both copper and gold in the world. Based on 699 holes drilled through the end of 2014 the Pebble deposit includes a total identified resource of 12 billion tons at 0.34 percent copper, 0.023 percent molybdenum, 0.009 ounce of gold per ton, and 0.4 ounce of silver per ton, which equates to 81.8 billion pounds of copper and 107.9 million ounces of gold (appendix F). Since 2001, when Northern Dynasty acquired the right to earn an interest in Pebble, more than $\$ 700$ million has been expended to advance the project, of which approximately $\$ 573$ million was provided by a wholly-owned subsidiary of Anglo American PLC, which participated in the Pebble Limited Partnership from 2007 until returning 100 percent interest in the Pebble Partnership to Northern Dynasty in 2013. In addition to their main Pebble resource, Northern Dynasty holds other identified prospects including a porphyry copper-gold-molybdenum deposit, a porphyry copper zone, a gold-copper skarn occurrence, and gold showings along the extensive northeast-trending mineralized system that underlies the Pebble property. Northern Dynasty completed a small drill and sampling program at Pebble during 2014. Other fieldwork included the continuation of baseline environmental data collection that has been ongoing since 2004. Northern Dynasty reported that environmental baseline data reports through 2014 are being integrated with a 27,000-page environmental baseline document published by the Pebble Partnership in 2012 so that this information can be shared with State and Federal agencies and the public as part of the future permitting process.

WestMountain Gold Inc. continued its bulk sampling program at Terra, a high-grade gold project approximately 125 miles west-northwest of Anchorage. The company reports that the pilot mill and gravity recovery system at Terra recovered 1,350 ounces of gold and 550 ounces of silver from about 500 tons of material that was processed on site during 2014. Most bulk samples came from the Ben Vein, with an identified resource of 940,199 tons at 0.446 ounce of gold per ton, and 0.82 ounce of silver per ton (appendix F). Geologic modeling of the drill-tested portion of Ben indicates the high-grade vein is open to the north and at depth. The company spent early summer repairing winter damage and refurbishing the pilot-mill equipment. The mill was down again in July for repairs before operations smoothed during the final two months of summer operations. During the 67 days of trouble-free operation, the mill processed ore at a rate of about 8 tons per day. Outcropping veins have been discovered in four other zones-EH, SD, Fish, and Ice-along a 5-mile region of the Terra property. The Ice vein, some 2.5 miles south of the Ben resource, is of particular interest to WestMountain. 
In addition to high-grade vein mineralization, the Terra project also hosts a bulk tonnage target at Camp Creek.

At least 27 individuals and companies completed more than $\$ 200,000$ of exploration on placer properties in Alaska's Southwestern region during 2014.

\section{SOUTHEASTERN REGION}

Approximately $\$ 30$ million was invested in exploring for a diverse suite of metals - including gold, silver, copper, lead, zinc, iron, platinum-group elements (PGE), and rare-earth elements-in Alaska's Southeastern region during 2014. The diverse metal suite is indicative of the region's multiple and overlapping metallogenic environments and complex geology. Greens Creek Mine is one of the highest-grade volcanogenic massive-sulfide (VMS) deposits in the world and historic lodegold production, mostly from the Juneau gold belt, is still higher than any of the state's other regions.

Coeur Mining Inc. spent approximately $\$ 11.8$ million on exploration focusing on higher-grade zones of gold mineralization at and around its Kensington Mine, approximately 45 miles north of Juneau. This work included 99,263 feet of drilling, primarily focused on expanding recently discovered zones of high-grade gold mineralization near the Kensington Main deposit currently being mined and the neighboring historic Jualin Mine (photo 8). Drilling returned multiple intercepts of greater than 1.0 ounce of gold per ton over estimated true widths of 1.3 to 8.6 feet in both areas (table 10). Drilling results provided new inferred resources at Kensington and Jualin at a higher grade to largely replace the removal of gold ounces from

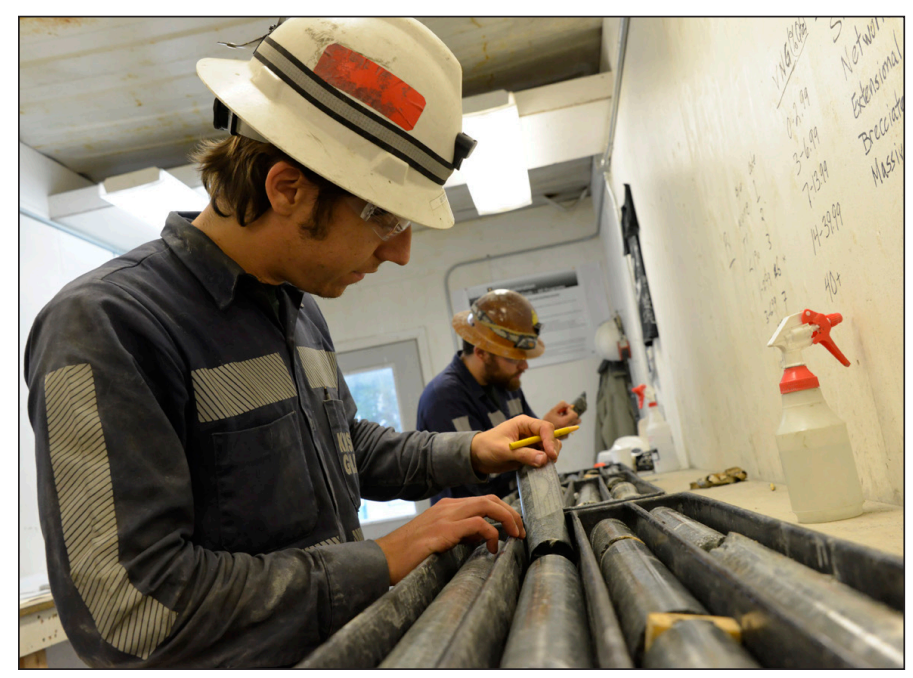

Photo 8. Geologists logging core at the Kensington project, northwest of Juneau, in southeastern Alaska. Coeur Alaska Inc. drilled 99,263 feet of core at the Kensington and Jualin deposits in 2014. Coeur expects to release a new mine plan in 2015 that will focus on higher-grade ore identified during the 2014 drilling program. Photo provided by Coeur Alaska Inc. previously reported, lower-grade, marginally economic reserves (see Development and Production section). At the end of 2014 the Kensington deposit had a reported reserve of 3.403 million tons at 0.185 ounce of gold per ton within a total identified resource of 6.591 million tons at 0.240 ounce of gold per ton, containing 1.583 million ounces of gold (appendix F), 153,000 fewer ounces than reported at the end of 2013. Coeur Mining is particularly excited about exploration results at the historic Jualin deposit situated 8,250 feet southeast of the current mining site at Kensington, which resulted in a newly reported inferred resource of 289,000 tons at 0.619 ounce of gold per ton, containing 179,000 ounces gold; this resource is more than twice the average grade of the total Kensington resource. The higher-grade resources at Jualin, which are found in a zone known as Vein 4, are being incorporated into a new mine plan for Kensington. Permitting began in 2014 for underground development to provide access to underground drill stations. Coeur says drilling in Vein 4 is expected to continue through 2015 and 2016 with initial production expected in 2017 . Once underground development has advanced, drilling is expected to also focus on further delineation of Vein 5 , which has been encountered about 500 feet beneath Vein 4.

Exploration at Hecla Mining Co.s Greens Creek Mine has been successful at replenishing reserves and resources since the mine's opening in 1989. The 2014 program at Greens Creek proved no different; Hecla continued an 11-year trend by increasing the silver and gold reserves to 7.695 million tons with 3.1 percent lead, 8.3 percent zinc, 0.100 ounce of gold per ton, and 12.2 ounces of silver per ton at its Greens Creek Mine in Southeastern Alaska in 2014, despite using lower metal prices for the calculation. At the end of 2014, Greens Creek had 11.97 million tons of total identified resource at 3.04 percent lead, 7.8 percent zinc, 0.098 ounce of gold per ton, and 12.5 ounces of silver per ton, which contains 150.0 million ounces of silver, a 9 percent increase in tons and a 12 percent increase from the 2013 resource. Exploration focused on definition and exploration drilling in the Greens Creek deposit, a polymetallic, volcanogenic massive-sulfide (VMS) deposit hosted in marine metasedimentary and mafic to ultramafic metavolcanic and metaplutonic rocks. Mineralization lenses are localized along the contact between a structural hanging wall of quartz-micacarbonate phyllites, and a structural footwall of graphitic and calcareous argillite. The host rocks, including the mineralized contact, are multiply folded and faulted, resulting in ore bodies with a complex geometry. During 2014 Hecla focused much attention on definition drilling and testing extensions of the Deep 200 South zone, which extends more than 3,000 feet along strike and more than 1,000 feet along dip. Hecla's exploration has defined three stacked folds of high-grade mineralization in the Deep 200 South that represent up to 600 feet 


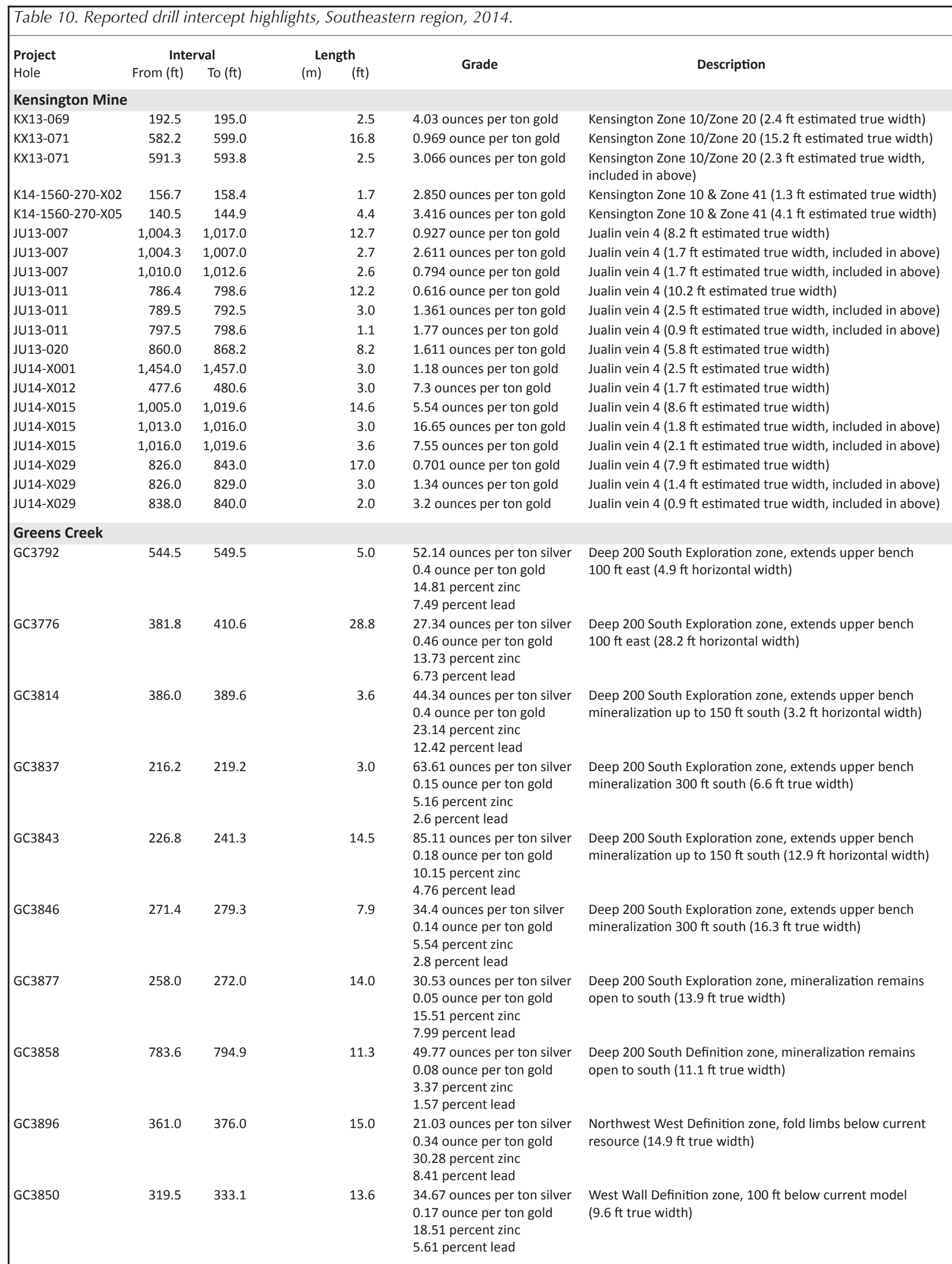




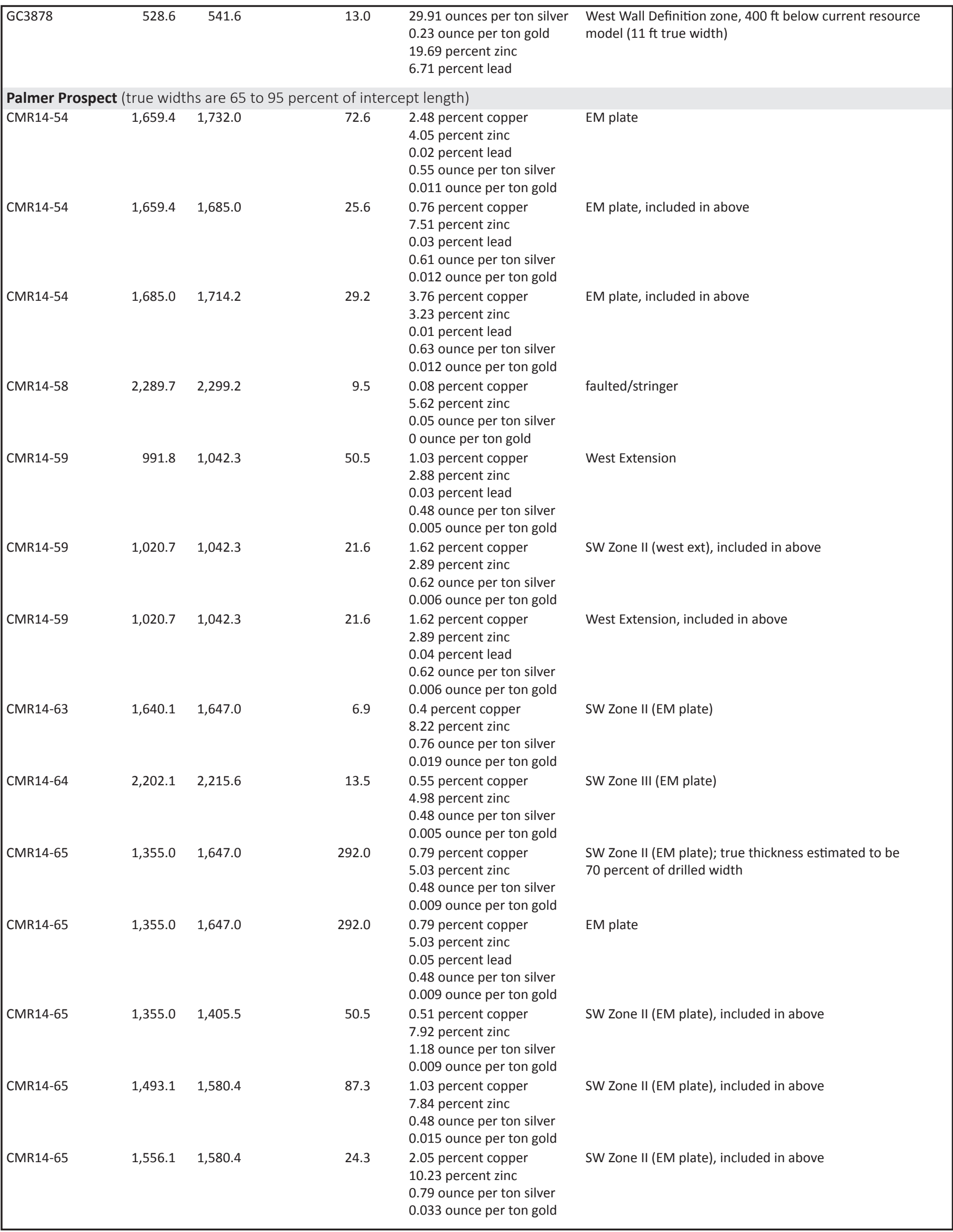




\begin{tabular}{|c|c|c|c|c|c|c|}
\hline CMR14-65 & $1,640.1$ & $1,647.0$ & & 6.9 & $\begin{array}{l}0.4 \text { percent copper } \\
8.22 \text { percent zinc } \\
0.11 \text { percent lead } \\
0.76 \text { ounce per ton silver } \\
0.019 \text { ounce per ton gold }\end{array}$ & EM plate, included in above \\
\hline CMR14-66 & $2,111.5$ & $2,148.6$ & & 37.1 & $\begin{array}{l}0.3 \text { percent copper } \\
3.95 \text { percent zinc } \\
0.62 \text { ounce per ton silver } \\
0.007 \text { ounce per ton gold }\end{array}$ & SW Zone II (EM plate) \\
\hline CMR14-66 & $2,111.5$ & $2,116.5$ & & 5.0 & $\begin{array}{l}0.21 \text { percent copper } \\
7.01 \text { percent zinc } \\
2.94 \text { ounces per ton silver } \\
0.025 \text { ounce per ton gold }\end{array}$ & SW Zone II (EM plate), included in above \\
\hline CMR14-67 & 397.0 & 447.2 & & 50.2 & $\begin{array}{l}0.13 \text { percent copper } \\
3.12 \text { percent zinc } \\
0.7 \text { ounce per ton silver } \\
0.004 \text { ounce per ton gold }\end{array}$ & RW Zone (NW ext) \\
\hline CMR14-67 & 400.3 & 413.1 & & 12.8 & $\begin{array}{l}0.19 \text { percent copper } \\
5.11 \text { percent zinc } \\
2.12 \text { ounces per ton silver } \\
0.011 \text { ounce per ton gold }\end{array}$ & RW Zone (NW ext), included in above \\
\hline \multicolumn{7}{|c|}{ Bokan Mountain (true widths are not reported) } \\
\hline LM14-137 & $1,026.2$ & $1,035.7$ & 2.87 & 9.4 & $\begin{array}{l}0.563 \text { percent LREO } \\
\text { (light rare-earth oxide) } \\
0.483 \text { percent HREO } \\
\text { (heavy rare-earth oxide) } \\
1.048 \text { percent TREO } \\
\text { (total rare-earth oxide) }\end{array}$ & In-fill from pad 14.3 \\
\hline LM14-138 & 313.0 & 319.9 & 2.10 & 6.9 & $\begin{array}{l}0.628 \text { percent LREO } \\
0.813 \text { percent } H R E O \\
1.441 \text { percent TREO }\end{array}$ & In-fill from pad $14-10$ \\
\hline LM14-142 & 166.1 & 174.1 & 2.42 & 7.9 & $\begin{array}{l}0.433 \text { percent LREO } \\
0.597 \text { percent HREO } \\
1.03 \text { percent TREO }\end{array}$ & In-fill from pad $14-15$ \\
\hline LM14-142 & 526.8 & 535.8 & 2.76 & 9.1 & $\begin{array}{l}1.187 \text { percent LREO } \\
0.462 \text { percent HREO } \\
1.649 \text { percent TREO }\end{array}$ & In-fill from pad $14-15$ \\
\hline LM14-142 & 577.4 & 588.5 & 3.37 & 11.1 & $\begin{array}{l}1.187 \text { percent LREO } \\
0.335 \text { percent HREO } \\
1.899 \text { percent TREO }\end{array}$ & In-fill from pad $14-15$ \\
\hline LM14-142 & 610.6 & 620.1 & 2.88 & 9.4 & $\begin{array}{l}0.678 \text { percent LREO } \\
0.439 \text { percent } H R E O \\
1.117 \text { percent TREO }\end{array}$ & In-fill from pad $14-15$ \\
\hline LM14-143 & $1,143.4$ & $1,153.2$ & 3.00 & 9.8 & $\begin{array}{l}0.429 \text { percent LREO } \\
0.327 \text { percent } H R E O \\
0.755 \text { percent TREO }\end{array}$ & Downdip extension from pad $14-9$ \\
\hline LM14-147 & 602.6 & 622.0 & 5.91 & 19.4 & $\begin{array}{l}0.494 \text { percent LREO } \\
0.286 \text { percent HREO } \\
0.779 \text { percent TREO }\end{array}$ & Downdip extension from pad $14-16$ \\
\hline LM14-148 & 821.7 & 829.2 & 2.29 & 7.5 & $\begin{array}{l}0.616 \text { percent LREO } \\
0.516 \text { percent HREO } \\
1.132 \text { percent TREO }\end{array}$ & Downdip extension from pad $14-9$ \\
\hline LM14-150 & 902.8 & 910.8 & 2.45 & 8.0 & $\begin{array}{l}0.649 \text { percent LREO } \\
0.471 \text { percent } H R E O \\
1.12 \text { percent TREO }\end{array}$ & Downdip extension from pad $14-9$ \\
\hline \multicolumn{7}{|c|}{ Salt Chuck (drill hole intervals not reported) } \\
\hline NPH-14-07 & & & 0.34 & 1.1 & $\begin{array}{l}0.412 \text { ounce per ton gold } \\
0.74 \text { percent copper }\end{array}$ & $\begin{array}{l}\text { Sulfides in quartz-calcite-epidote veining, tested extension of } \\
2012 \text { gold intercept }\end{array}$ \\
\hline NPH-14-05 & & & 1.10 & 3.6 & 0.038 ounce per ton gold & $\begin{array}{l}\text { Sulfides in quartz-calcite-epidote veining, tested extension of } \\
2012 \text { gold intercept }\end{array}$ \\
\hline NPH-14-10 & & & 1.00 & 3.3 & 0.038 ounce per ton gold & $\begin{array}{l}\text { Sulfides in quartz-calcite-epidote veining, tested extension of } \\
2012 \text { gold intercept }\end{array}$ \\
\hline NPH-14-11 & & & 2.00 & 6.6 & 0.018 ounce per ton gold & $\begin{array}{l}\text { Sulfides in quartz-calcite-epidote veining, tested extension of } \\
2012 \text { gold intercept }\end{array}$ \\
\hline NPH-14-14 & & & 0.34 & 1.1 & 0.027 ounce per ton gold & $\begin{array}{l}\text { Eastern North Pole Hill Area, pyrite-chalcopyrite in quartz- } \\
\text { carbonate-epidote veinlets, test of gold-in-soil anomaly }\end{array}$ \\
\hline NPH14-12 & & & 2.00 & 6.6 & 0.42 percent copper & $\begin{array}{l}\text { Eastern North Pole Hill Area, pyrite-chalcopyrite in quartz- } \\
\text { carbonate-epidote veinlets, test of gold-in-soil anomaly }\end{array}$ \\
\hline NPH-14-15 & & & 71.00 & 232.9 & 0.12 percent copper & Central North Pole Hill area, disseminated chalcopyrite \\
\hline
\end{tabular}


of downdip continuity. In particular, the upper fold or upper bench mineralization had some of the widest and highest-grade intercepts in recent history at the mine, with grades of up to 85.1 ounces of silver per ton over 12.9 feet (table 10). Hecla also continued definition drilling, encountering thicker and more consistent mineralization than the 2013 deposit model in the 200 South and Northwest West (NWW) zones; intercepts ranging from 21.0 to 34.7 ounces of silver per ton over 9.6 to 14.7 feet (table 10) extended the mineralization downdip. Surface exploration drilling consisting of 23,214 feet in five holes targeting Killer Creek, 1 mile northwest of the mine, has confirmed and expanded on a broad, locally high-grade copper, silver, and zinc system associated with stockwork veining characteristic of footwall mineralization. At depth a number of holes intersected densely pyritic laminated argillite that was anomalous in silver and zinc. Hecla reports that this horizon may imply the existence of another mine horizon that could host another ore deposit at Killer Creek and elsewhere on the property. Hecla anticipates an aggressive 2015 underground drilling program with $\$ 5.8$ million and 126,700 feet budgeted for infill exploration on Lower NWW, Deep 200 South, East Ore, Deep Southwest, and 9a zones, and \$2.4 million and 46,000 feet exploring strike and downdip extensions of the Deep 200 South, 5250, 9a, Central West, East, Southwest Bench upper contact, and Gallagher Fault Block areas. In addition, a 10,000 foot surface drilling program is anticipated to explore the stockwork and mineralized argillite horizon at Killer Creek and assess the base-metal-mineralized High Sore target within a mile to the southeast of the mine.

Constantine Metal Resources Ltd. completed 32,136 feet of drilling at its Palmer VMS project near Haines during 2014 (photo 9). This $\$ 5.3$ million program was conducted under a joint-venture option agreement with Dowa Metals \& Mining Co. Ltd., a Tokyo-based smelting and mining company. Under the agreement Dowa can earn a 49 percent interest in Palmer by investing $\$ 22$ million over 4 years. Through 2014 , the second year of its option agreement, Dowa Metals \& Mining has spent roughly $\$ 10$ million at Palmer. The Palmer project is a 108,000 acre property located 37 road miles north of Haines, Alaska. The property has at least 25 polymetallic and barite volcanogenic massive-sulfide (VMS) prospects hosted in a sequence of Triassic mafic to felsic metavolcanic and metasedimentary rocks. The 2014 drill program continued resource expansion at Glacier Creek prospect, which consists of five structurally and stratigraphically related massive-sulfide zones: RW East, RW West, and South Wall zones 1, 2, and 3. The South Wall zones are parallel layers of nearly vertical VMS mineralization that form the lower limb of a faulted asymmetric anticline, whereas the RW zones form the upper, nearly flat-lying limb of the same fold. The primary 2014 target was a 1,300 square foot conductor plate, identified with downhole geophysics, lying downdip and to the southwest of the previously-drill-identified extent of South Wall. Hole CMR14-54, the first hole to successfully penetrate the conductive plate, intersected 72.5 feet of massive sulfide averaging 2.48 percent copper, 4.05 percent zinc, 0.61 ounce of silver per ton, and 0.012 ounce of gold per ton (table 10). This intersection represents a 490 foot downplunge step-out of the South Wall zones. Several other holes intersected the conductive plate (table 10) and Constantine says that the 2014 wide-spaced drilling confirmed the conductor plate target is a sizeable new zone with high expansion potential. A new resource incorporating the 2014 drilling will be issued in 2015 . In September, Constantine signed an upland mining lease on roughly 92,000 acres of lands surrounding the Palmer property through a competitive lease offering by the Alaska Mental Health Trust Authority. In addition to being prospective for VMS mineralization, the newly acquired lease also covers upland portions of the Porcupine placer district, which is estimated to have produced 82,489 ounces of gold since production began.

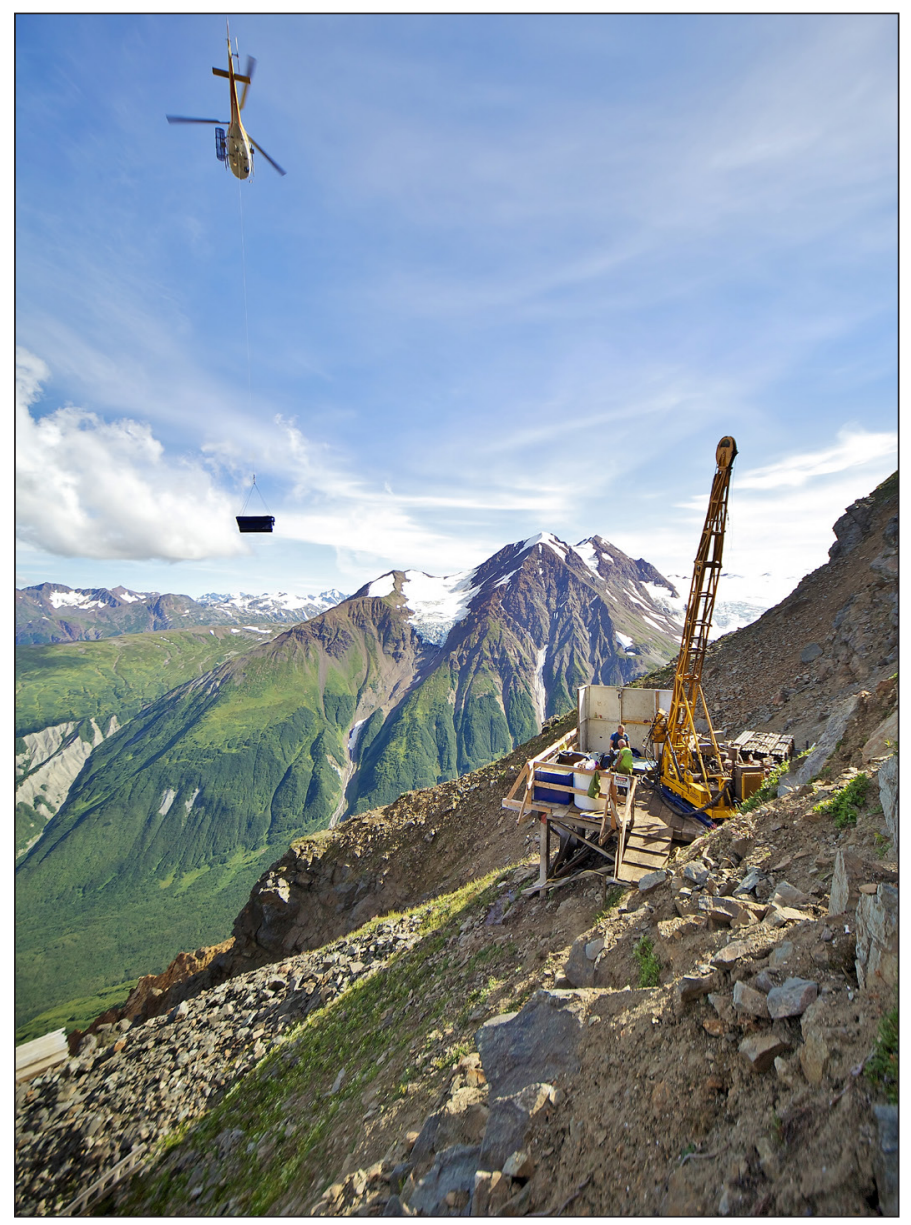

Photo 9. Helicopter slinging core from a drill site at the Palmer project northwest of Haines, Alaska. Constantine Metal Resources Ltd. completed 32,136 feet of drilling at the Glacier Creek massivesulfide prospect in 2014. Results from this drilling will be included in a revised resource estimate for the Palmer project, expected in 2015. Photo provided by Constantine Metal Resources Ltd. 
Ucore Rare Metals Inc. completed a 17-hole drill program in 2014 to expand the Dotson Ridge deposit at Bokan Mountain and to upgrade the inferred resource announced late in 2013. The total identified 2014 resource is 5.4 million tons averaging 0.614 percent total rare-earth oxides (TREO) or 66.3 million pounds TREO, of which 60 percent is in the inferred category (appendix F). Roughly 40 percent of the rare-earth oxides in the resources are the more-highly-valued heavy rare earths, many of which are considered critical to the green energy, defense, and high-technology sectors. The Dotson Ridge deposit is a west-northwest zone of at least 25 individual subparallel veins associated with the Jurassic Bokan Mountain peralkaline granite. The 2014 program included the drilling of 12 infill holes; ten holes cut significant mineralization, including several intercepts with $>1$ percent TREO (table 10). Five additional holes tested the mineralized zone 330 feet below previous drill intersections; four of the holes intersected significant mineralization ranging from 0.75 to 1.1 percent TREO over widths of 7.5 to 19.4 feet (table 10). In addition to exploration drilling, Ucore completed a number of geotechnical holes and groundwater monitoring wells to obtain supplementary data for use in engineering and permitting the project. This field work is part of a larger program to prepare a plan of operation that can be submitted to the U.S. Forest Service for permitting and to finalize a feasibility study in 2015. The feasibility study builds on a 2012 preliminary economic assessment that anticipates an underground mine feeding a 1,653-tons-per-day mill and a state-of-the-art processing facility at Bokan Mountain. The planned mill uses a two-stage process to upgrade the ore, including $\mathrm{x}$-ray fluorescence sorting on crushed ore, followed by grinding and magnetic separation prior to the final acid leach, which will treat only 375 tons per day. The operation outlined in the PEA anticipates the production of about 2,500 tons of rare-earth oxides per year during the first five years of full production, including an annual output of 105 tons of dysprosium oxide, 15 tons of terbium oxide, and 568 tons of yttrium oxide. The 2014 Alaska State Legislature authorized the Alaska Industrial Development and Export Authority (AIDEA), subject to due diligence, to issue as much as $\$ 145$ million in bonds to finance infrastructure construction if the project advances.

Pure Nickel Inc. completed 5,577 feet of drilling in nine holes at its Salt Chuck copper-gold-silver-PGE property on Prince of Wales Island in the Southeast region. The Salt Chuck Property, consisting of 146 federal claims on Prince of Wales Island, is a historical mine that from 1907 through 1931 produced an estimated 6.2 million pounds of copper, 55,620 ounces of silver, 20,540 ounces of palladium, and 11,740 ounces of gold from 300,000 tons of ore. The 2014 program targeted selected soil geochemical anomalies in the North Pole Hill area and followed up on 2012 drilling, which encountered 8.5 feet averaging 0.849 ounce of gold per ton and 0.79 percent copper. The company reports that eight of the holes encountered pyrite-chalcopyrite mineralization associated with hydrothermal quartz-calcite-epidote veining similar to the 2012 intercept. The highest-grade intercept in 2014 was 1.6 feet of 0.411 ounce of gold per ton and 0.74 percent copper, while the thickest intercept was 232.9 feet of 0.12 percent copper. Pure Nickel said the results of the 2014 drill program indicate that the Salt Chuck property hosts numerous mineralized structures with locally elevated gold and copper values. These structures might be related to a major fault, which has not yet been investigated, that bisects the Salt Chuck intrusion in the central part of the property. Soil geochemistry has proven to be an excellent indicator of bedrock mineralization, and numerous anomalies remain to be tested. The company said follow-up work will include additional soil surveys across the property and detailed geologic mapping of the mineralized structures.

Roughly $\$ 125,000$ was invested in placer gold exploration in the Southeastern region during 2014.

\section{ALASKA PENINSULA REGION}

The Alaska Peninsula and the Aleutian Islands, an active island-arc environment along the Pacific Ring of Fire, was the target of more than $\$ 1$ million in mineral exploration during 2014.

The largest program in the region was carried out by Millrock Resources Inc. on their Alaska Peninsula project, a 1.68-millionacre tract of Bristol Bay Native Corp. (BBNC) lands under an exploration agreement. The project stretches for more than 75 miles along the southeastern side of the Alaska Peninsula and covers porphyry copper-gold-molybdenum prospects as well as intrusive-related deposits (photo 10). The exploration was initiated with 1,140 line-kilometers of high-resolution airborne magnetic and radiometric surveys over the Kawisgag, Mallard Duck Bay, and Dry Creek porphyry copper-molybdenumgold prospects. Geologic mapping, rock sampling, and soil sampling, along with the geophysics and previous work, were used to develop drill targets for a 2015 program. The Kawisgag prospect, 50 miles southwest of Chignik, hosts two main centers of mineralization that are inferred to merge below the ridge that separates them. Airborne magnetic surveys completed in 2014 defined the limits of the magnetic intrusions and magnetic alteration. Millrock said the geophysical work, along with geochemical sampling, has delineated a number of strong drill targets. The Mallard Duck Bay prospect, 6 miles southwest of Chignik, is marked by a 2,000-acre alteration zone that has a strong chargeability anomaly coincident with anomalous surface geochemistry, and an identified potassic alteration zone, but has not yet been drilled. The Dry Creek (formerly known as Bee Creek) prospect, roughly 15 miles north of Chignik, is 


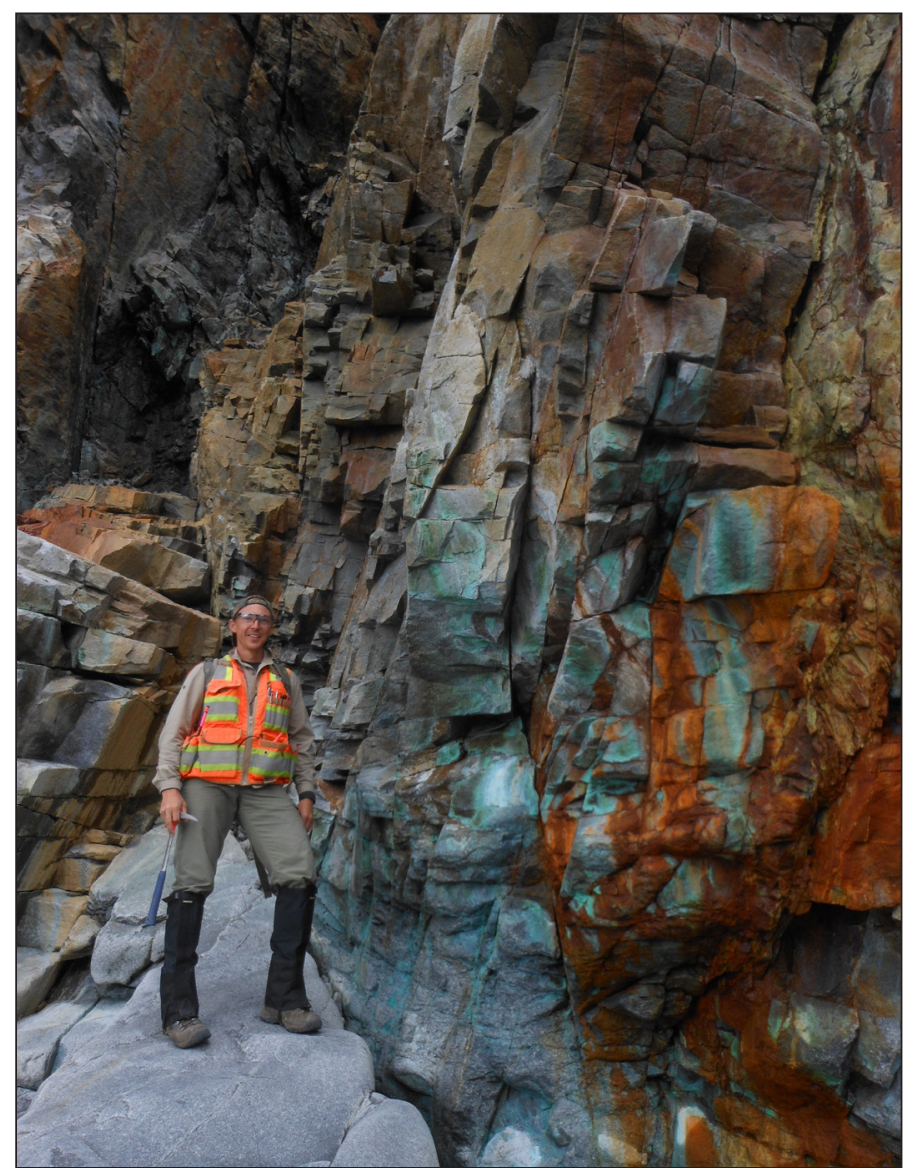

Photo 10. First Quantum Minerals Ltd. Principal Geologist Tim Ireland on outcropping porphyry copper-style mineralization on the Alaska Peninsula. Millrock Resources Inc. partnered with First Quantum to explore the Dry Creek (Bee Creek), Kawisgag, and Mallard Duck Bay prospects on Bristol Bay Native Corp. lands in 2014. Photo provided by Millrock Resources Inc.

the most advanced prospect at the Alaska Peninsula project. Previous exploration includes surface exploration and drilling by Bear Creek Mining in 1976 and Metallica Resources Inc. and Full Metal Minerals Ltd. in 2005 and 2006. One of the historical holes intersected 387 feet averaging 0.31 percent copper, 0.009 percent molybdenum, and 0.004 ounce of gold per ton. Mineralization at Dry Creek is hosted in hornfelsed sediments intruded by multi-phase diorite intrusive rocks containing mineralized veins along with disseminated chalcopyrite, molybdenite, and pyrite. Vein styles and mineralogy, along with a potassic alteration fringed by phyllic alteration, are all consistent with a porphyry system. The 2014 Millrock work program identified several drill targets, cost $\$ 600,000$, and was funded by First Quantum Minerals Ltd. through a binding letter of agreement. At the end of the year First Quantum exercised its option to enter into a joint-venture agreement on the Alaska Peninsula project and fund a drilling program to be completed in the third quarter of 2015. Dry Creek is expected to be a primary target for drilling planned for 2015.
Redstar Gold Corp. carried out a two-month surface program at Unga, a high-grade epithermal gold-silver project on Unga Island about 50 miles southwest of Millrock's Alaska Peninsula project. The Unga project includes the historical Apollo Mine, which produced approximately 100,000 ounces of gold from 1892 to 1913 . Redstar's 2014 program investigated the highest-priority targets along the Apollo-Sitka and Shumagin trends. Each of these subparallel, northeast-striking trends are approximately 6 miles long and cut across the southeast corner of Unga Island. The initial focus of this program was on a 1.6-milelong corridor of alteration and veining along the Apollo-Sitka trend. The area sampled centered on the Apollo Mine area and included the Sitka Mine area to the northeast, Empire Ridge to the southwest, and the Rising Sun prospect to the southeast. In December Redstar reported that selective rock-chip sampling of exposed bedrock in this area returned assays of 11.667 ounces of gold per ton and 7.76 ounces of silver per ton. Results from continuous chip trench sampling in the hanging wall of the historical Sitka stope produced results of up to 0.890 ounce of gold per ton and 3.74 ounces of silver per ton. Redstar reports that a continuous gold-silver geochemical soil anomaly covering the Sitka and Apollo mine areas has been extended by roughly 4,265 feet to the southwest, from Apollo through Empire Ridge. The 2014 program also included testing of the Shumagin and Aquila, two prospective areas at opposite ends of the Shumagin trend. At the Shumagin prospect, at the northeast end of the trend, a soil sample grid of roughly 2,460 by 650 feet tested the western extension of known surface and subsurface mineralization along inferred structures. Redstar said the results from this survey identified a gold and silver geochemical soil signature over areas of historical trenching, extending the anomaly to the southwest by approximately 1,300 feet. Rock-chip sampling of outcropping vein breccias and stockwork at Shumagin produced results of up to 0.292 ounce of gold per ton and 2.17 ounces of silver per ton. At the Aquila prospect, at the southwestern end of the Shumagin trend, a series of reconnaissance soil lines returned anomalous gold and silver values. In addition to the fieldwork, Redstar geologists completed an in-depth review of historical drilling carried out at the Shumagin prospect in advance of a drill program planned for early 2015.

Full Metal Minerals Ltd. announced the transfer of its Pyramid project, just north of Unga Island on the Alaska Peninsula, to CopperBank Resources Corp., a new company resulting from a 2014 merger of Full Metal, Enexco International Inc., and Choice Gold Corp. The total identified resource at Pyramid is 191 million tons at 0.4 percent copper, 0.02 percent molybdenum, and 0.003 ounce per ton gold; approximately 60 percent of the resource lies in a supergene enrichment zone. CopperBank Resources has not yet announced future exploration plans for Pyramid. 


\section{DEVELOPMENT AND PRODUCTION}

This edition of the report breaks with tradition by setting a new precedent of combining the narratives for development and production; however, we will continue efforts to tabulate, analyze, and portray development expenditures independently. Over the last 10 years the majority of development work has been conducted at mine sites and the development activities are integral to the mining operations. Additionally, there have been few purely development-stage projects. We believe that combining production and development into one narrative will result in a more readable, less disjointed description of industry activities.

\section{DEVELOPMENT DISCUSSION}

In this report, the development sector of the mining process refers to building infrastructure or conducting activities that facilitate production of mineral products. Development expenditures reflect actual expenditures at mines as well as sustaining capital. Sustaining capital includes equipment replacement and rebuilding, facility upgrades, and other expenditures that must be amortized or depreciated in accordance with tax laws; thus they are frequently reported as distinct line items in securities filings. Development activities, whether to build a new mine or make improvements to an existing mine, are often precursors to increased annual production or extended mine life.

Reported and estimated development expenditures in 2014 were 22 percent less than in 2013, with 85 projects reporting spending a total of approximately $\$ 281.7$ million. Significant development outlays (more than $\$ 5$ million per project) were noted at Red Dog, Fort Knox, Pogo, Kensington, and Greens Creek mines and the Donlin Gold project (all lode operations), and at the Nome offshore lease area (placer operations). Based on reported expenditures, Fort Knox Mine had the largest ongoing development project in Alaska. Ongoing capital maintenance expenditures exceeding $\$ 1$ million continued at the idled Nixon Fork mine. Three additional placer operations reported development expenditures of over $\$ 1$ million. Smaller development expenditures were reported at 73 placer, sand and gravel, and rock quarry operations statewide. Employment related to development in 2014 is estimated at 468 full-time-equivalent employees, 31 percent more than in 2013. Note that the low development workforce count in 2013 was a reporting anomaly from combined development and production labor numbers at two major mines. The 2014 development employment figure is a more accurate estimate calculated by applying the proportion of development and production expenditures to the total employment at mine sites that do not distinguish between development and production employees.

Development activities were reported in all regions of the state in 2014, with the Eastern Interior capturing 59 percent of the expenditures and 49 percent of the workforce (table 11; fig. 12). Locations of projects with significant development expenditures are shown in figure 13. Precious metals ${ }^{15}$ projects comprised 71 percent of the development expenditures in 2014.

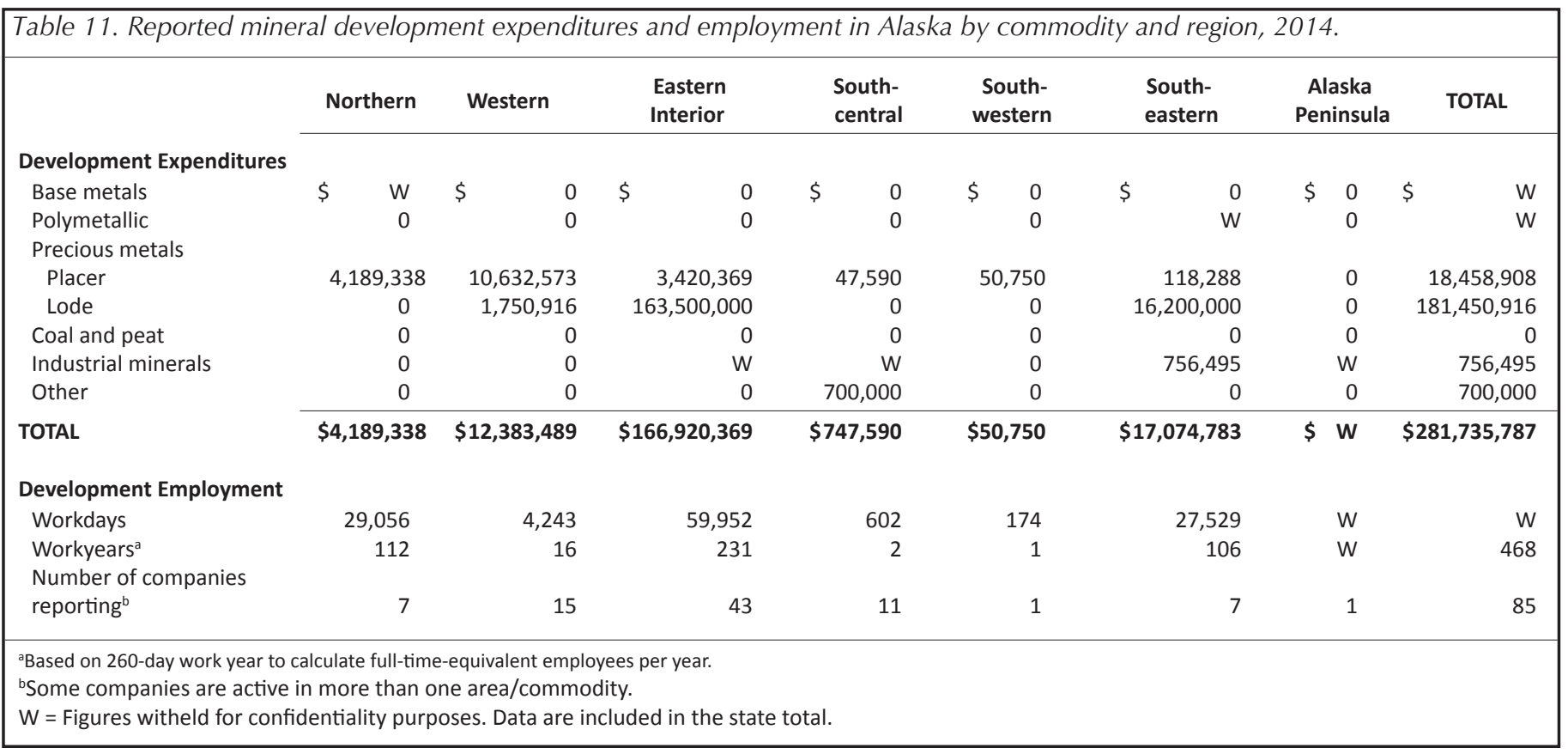

\footnotetext{
${ }^{15}$ Hecla Mining Co. considers silver to be the primary commodity at Greens Creek Mine and counts zinc, lead, and gold as byproducts. In our analysis we classify Greens Creek as a polymetallic mine.
} 
Figure 12. Development expenditures in Alaska by region, 2014.
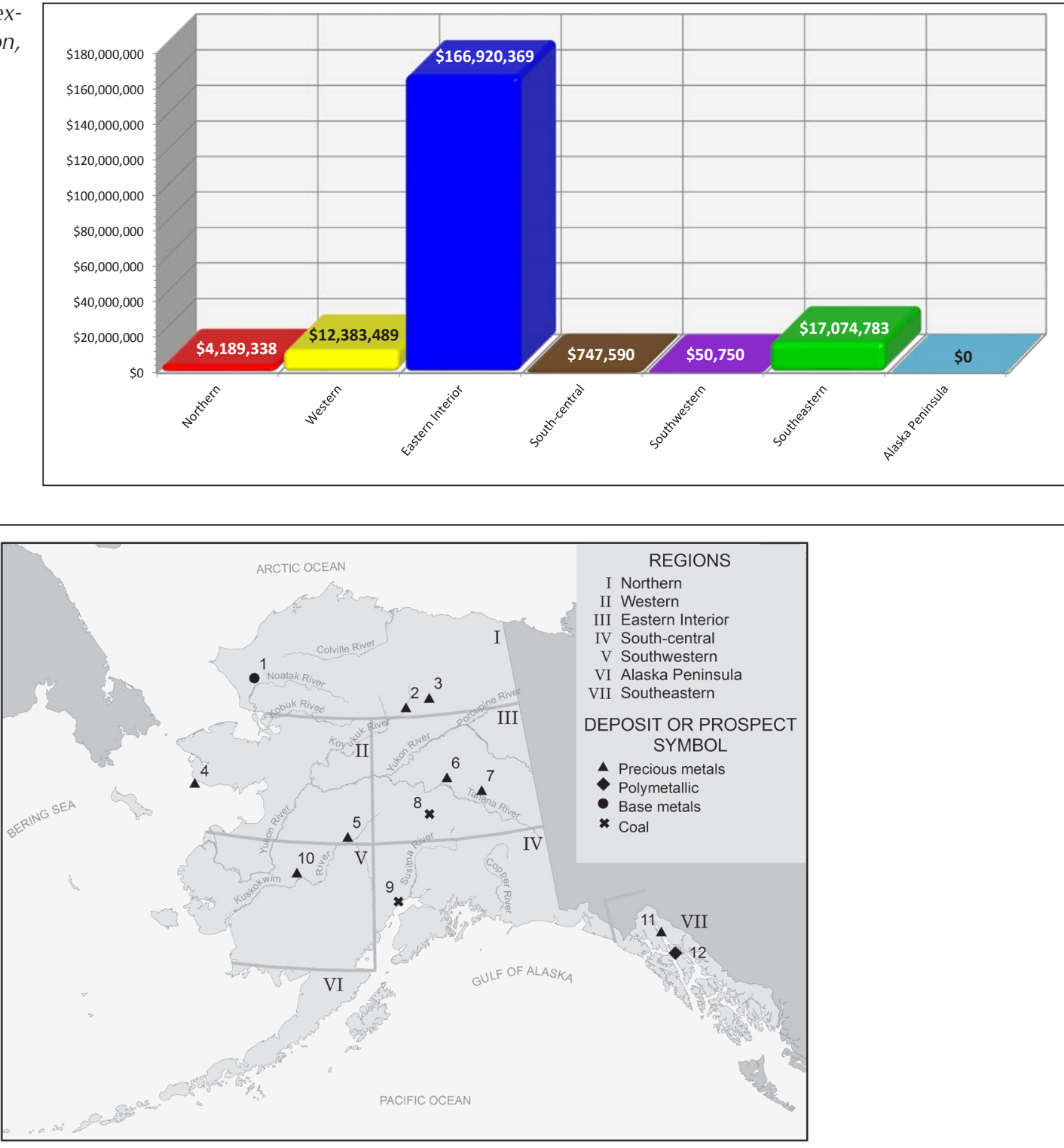

\section{Northern Region}

1. Red Dog Mine-Teck Alaska Inc.

2. Chandalar placer gold project—Goldrich NyacAu Placer LLC

3. Placer, Koyukuk mining district-Various

\section{Western Region}

4. Nome offshore lease area—Phoenix Offshore Mining Inc.

5. Nixon Fork Mine-Waterford Global Value L.P. Placer gold-Various (not shown on map)

\section{Eastern Interior Region}

6. Fort Knox Mine-Fairbanks Gold Mining Inc.

7. Pogo-Sumitomo Metal Mining Pogo LLC

8. Usibelli Coal Mine-Usibelli Coal Mine Inc. Placer gold-Various (not shown on map)

\section{South-central Region}

9. Chuitna Coal Project-PacRim Coal L.P. Industrial Minerals-One operator (not shown on map)

Placer gold—Various (not shown on map)

\section{Southwestern Region}

10. Donlin Gold project-Donlin Gold LLC

Placer gold - Various (not shown on map)

VI. Alaska Peninsula Region

Industrial minerals-One operator (not shown on map)

\section{Southeastern Region}

11. Kensington Mine-Coeur Alaska Inc.

12. Greens Creek Mine-Hecla Greens Creek Mining Co.

Industrial minerals - Various (not shown on map) Placer gold—Various (not shown on map)

Figure 13. Selected development projects, 2014. 
Since 2001, precious metals have been the impetus behind more than two-thirds of the annual development investment (table 12; fig. 14).

\section{PRODUCTION DISCUSSION}

The total value of mineral production in Alaska during 2014 is estimated at $\$ 3.28$ billion, 4.0 percent less than the 2013 value of $\$ 3.42$ billion (table 13). Mineral production was reported by at least one operator from every region in the state during 2014 (fig. 15). Metals (gold, silver, lead, and zinc) account for $\$ 3.21$ billion (almost 98 percent of the total), coal and peat add up to $\$ 52.5$ million, and industrial minerals account for $\$ 24.1$ million (table 13). Note that the industrial minerals (rock, sand, and gravel) and peat sectors represent estimated minimums of actual production due to chronic reporting shortfalls; reporting this year was especially poor.

Zinc returned to its place as the leading mineral product of the state with a value of $\$ 1.4$ billion in 2014, an increase of 21 percent and accounting for 42 percent of Alaska's production value (fig. 16). The annual value of zinc production exceeded that of gold from 1990 through 2011 (appendix C). Zinc's strong performance in 2014 is due to record production at Red Dog combined with strong zinc prices (table14; fig. 17). In contrast, reduced metal output from Fort Knox Mine and placer mines statewide combined with declining gold prices to result in a $\$ 1.2$ billion value of gold produced in 2014, a 23 percent decline from the record value in 2013.

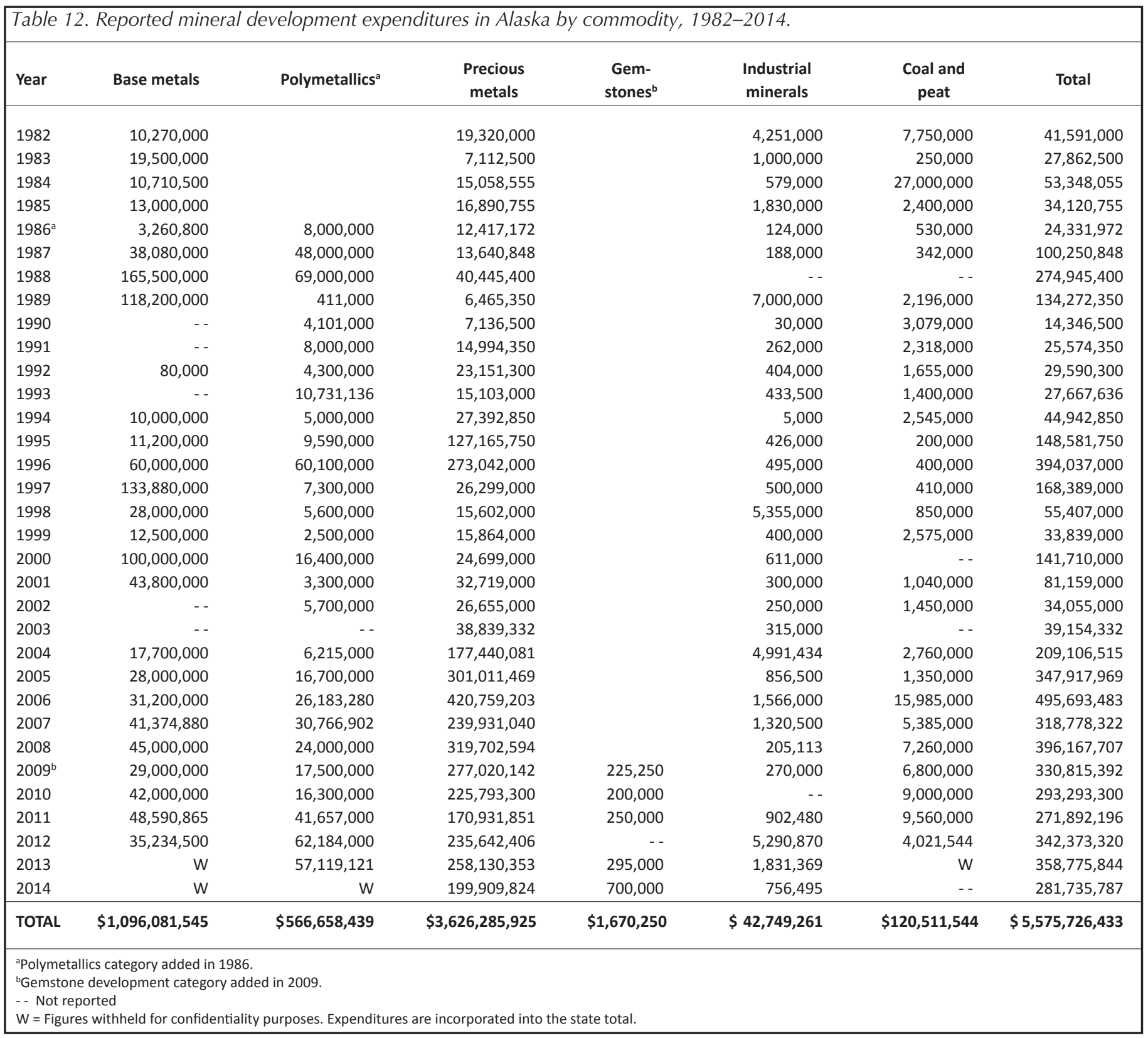


The average precious metal prices used in this report are the average daily London Metal Exchange (LME) price; base metal prices are the average weekly LME price (table 14; fig. 17). Some respondents reported actual unit values received for production; in cases where actual values were available, they were used in place of the average values. In general, however, metal values are those from the LME. This report uses the First Market Value (estimated gross value of mineral products at first wholesale) for production; it does not represent actual sales or gross income of producers, and does not take into account mining, shipping, smelting, and other costs incurred by the producer.

Commodity markets continue to be volatile and prices for some goods have been negatively affected. For example, the price of gold has dropped substantially over the last three years, while unit costs of production have not changed substantially, resulting in net earnings for gold producers that are disproportionately affected by commodity price swings. Royalty and production tax revenue to the State is much more sensitive to commodity

Figure 14. Mineral development expenditures in Alaska by commodity, 1982-2014.

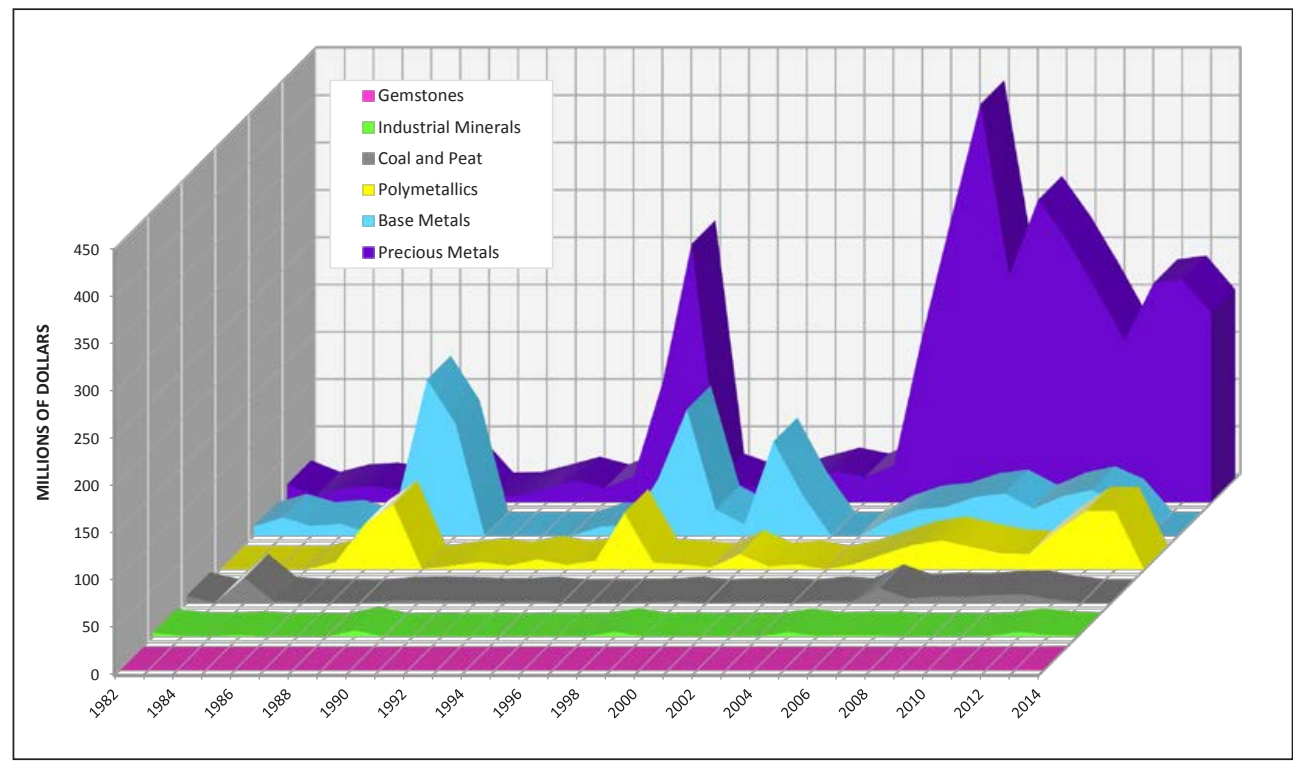

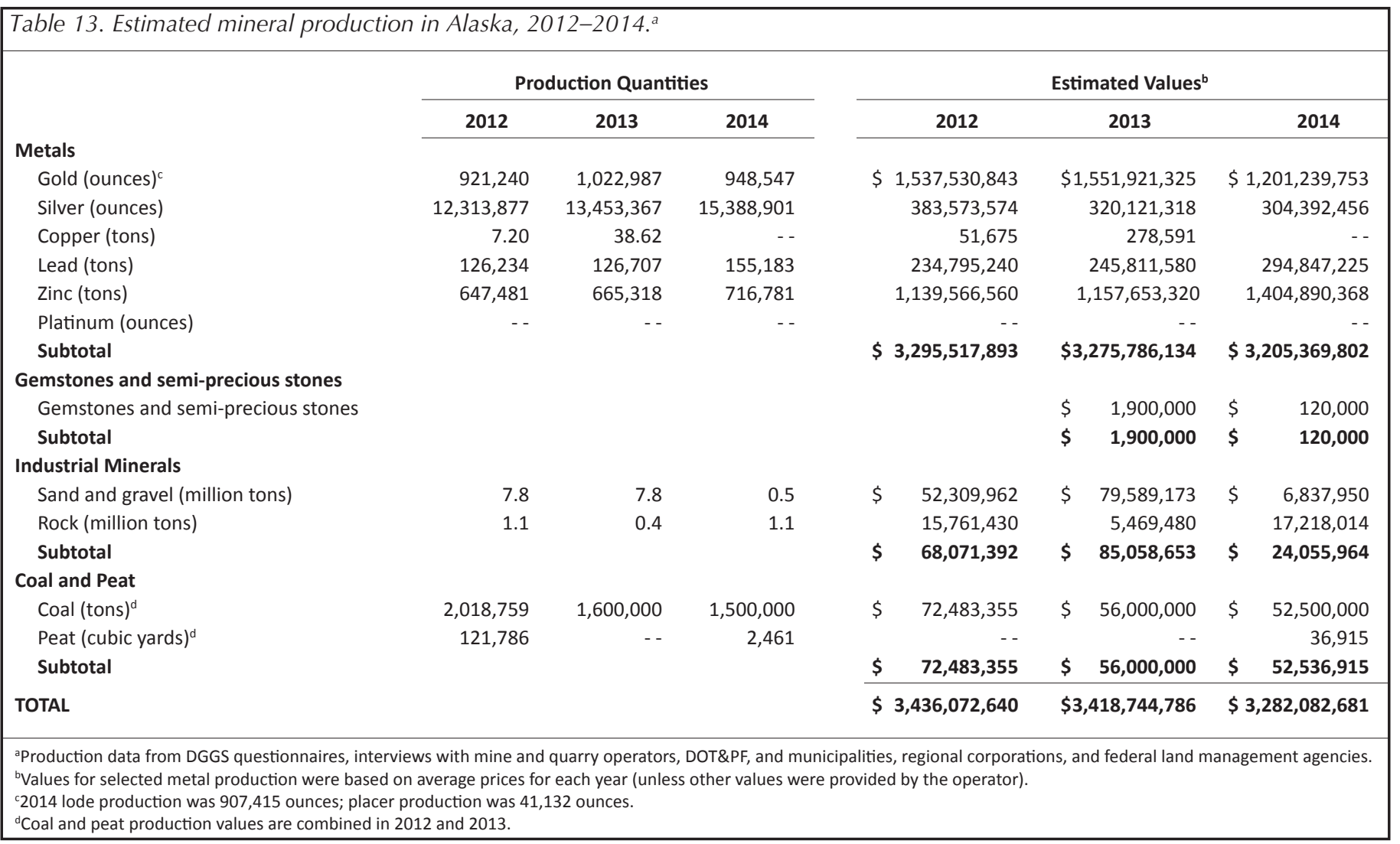




\section{Northern Region}

1. Red Dog Mine area-Teck Alaska Inc.-Zinc, lead, silver (germanium, indium, cadmium)

2. Industrial minerals_-Various operators—Rock, sand, gravel, and peat

3. Placer, Koyukuk mining district-Various operatorsGold

\section{Western Region}

4. Nome offshore lease area-Various operators-Gold

5. Placer, Fairhaven (Inmachuk-Candle) mining district/ area-Various operators-Gold

6. Placer, Innoko mining district/area-Various operators-Gold

\section{Eastern Interior Region}

7. Industrial minerals-Various operators-Rock, sand, and gravel

8. Placer, Fairbanks mining district/area-Various operators-Gold

9. Fort Knox Mine_-Fairbanks Gold Mining Inc.-Gold

10. Placer, Circle mining district/areaVarious operators-Gold

11. Pogo Mine-Sumitomo Metal Mining Pogo LLC-Gold

12. Placer, Fortymile mining district/areaVarious operators-Gold

13. Usibelli Coal Mine_-Usibelli Coal Mine Inc.-Coal

14. Placer, Bonnifield mining district/areaVarious operators-Gold

\section{South-central Region}

15. Placer, Yentna mining district/areaVarious operators-Gold

16. Industrial minerals-Various operatorsRock, sand, and gravel

\section{Southwestern Region}

17. Placer gold mines-Various operators-Gold

18. Terra exploration project-WestMountain Gold Inc.-Gold and silver from bulk sampling program Industrial minerals-One operator-Sand and gravel (not shown on map)

\section{Alaska Peninsula Region}

Industrial minerals-One operator-Rock (not shown on map)

\section{Southeastern Region}

19. Kensington Mine-Coeur Alaska Co.-Gold

20. Greens Creek Mine-Hecla Greens Creek Mining Co.-Silver, gold, lead, and zinc Industrial minerals-Various operators-Rock, sand, and gravel (not shown on map)

Placer gold mine-One operator-Gold (not shown on map)

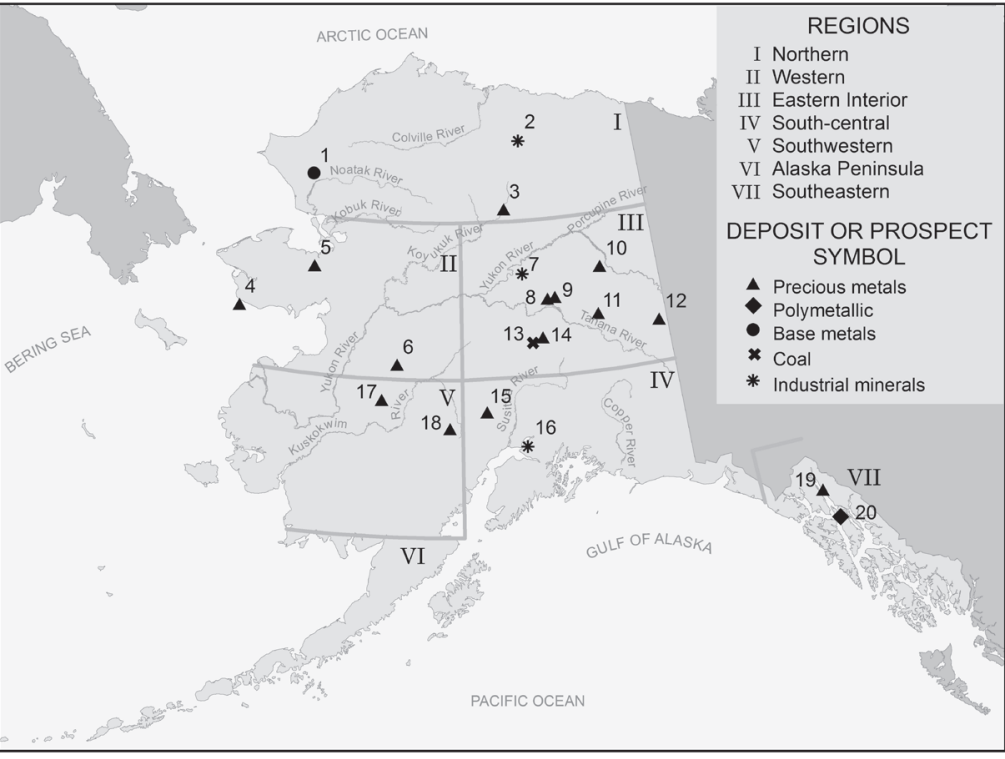

Figure 15. Selected production projects, 2014.

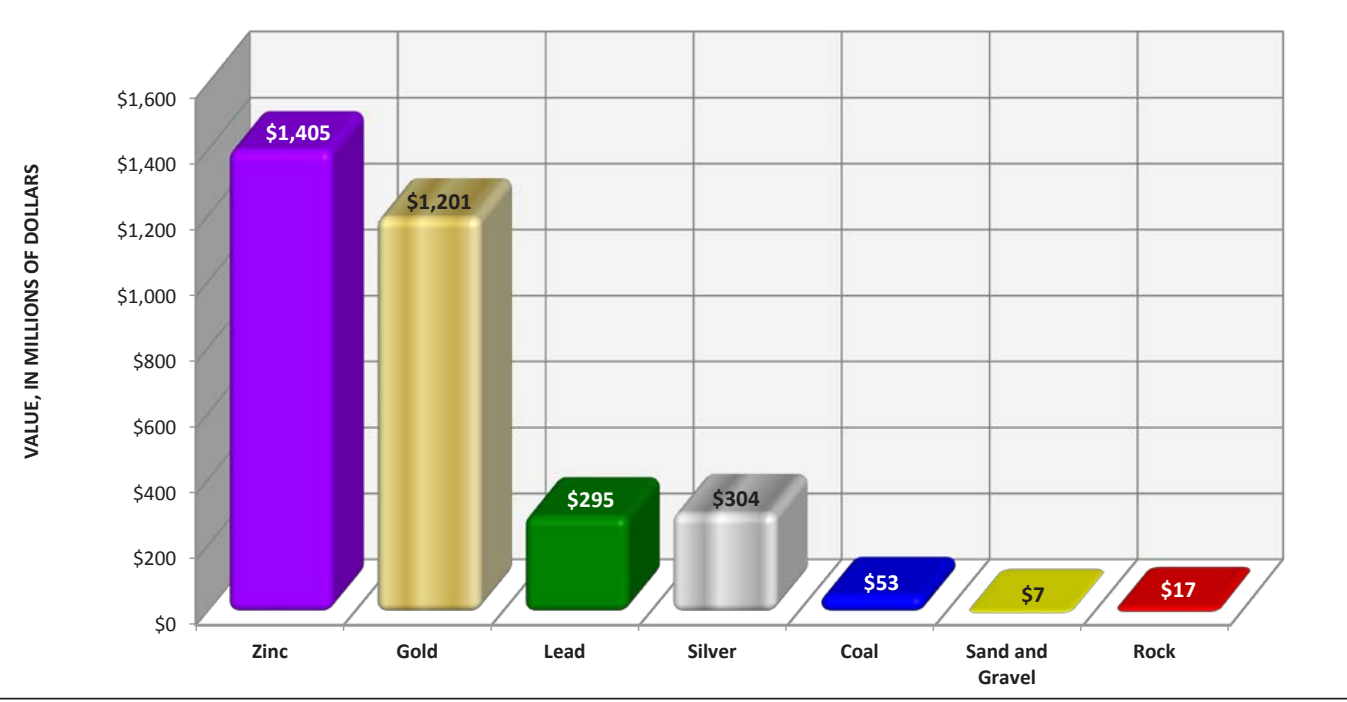

Figure 16. Estimated 2014 mineral production in Alaska by commodity. 
volatility than the First Market Value because royalties and production tax are based on net income.

Gold production totaling 948,547 ounces came from every region in the state in 2014 except for the Alaska Peninsula, with 80 percent of the total from the Eastern Interior (table 15). The Eastern Interior also had the largest number of producers, including the two largest mines, Fort Knox and Pogo. Southeast Alaska accounted for 19 percent of the state's gold, mostly from the Kensington gold and Greens Creek polymetallic mines, which are the third and fourth largest gold producers. Reported

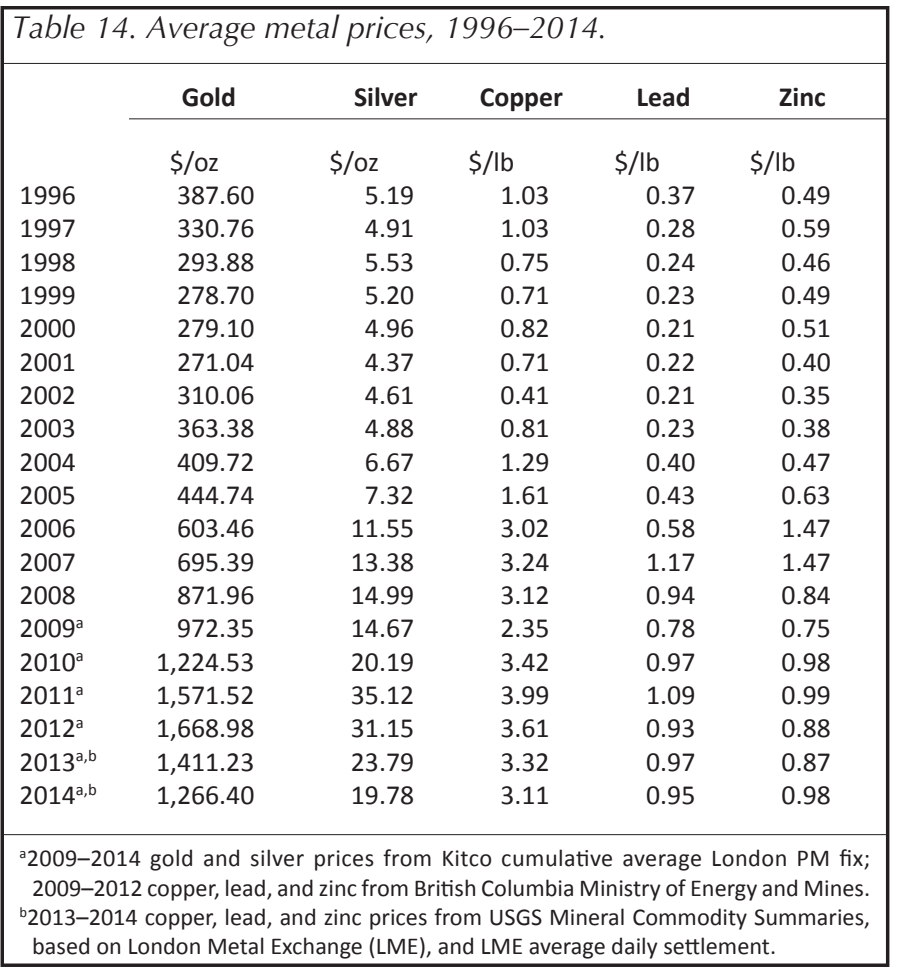

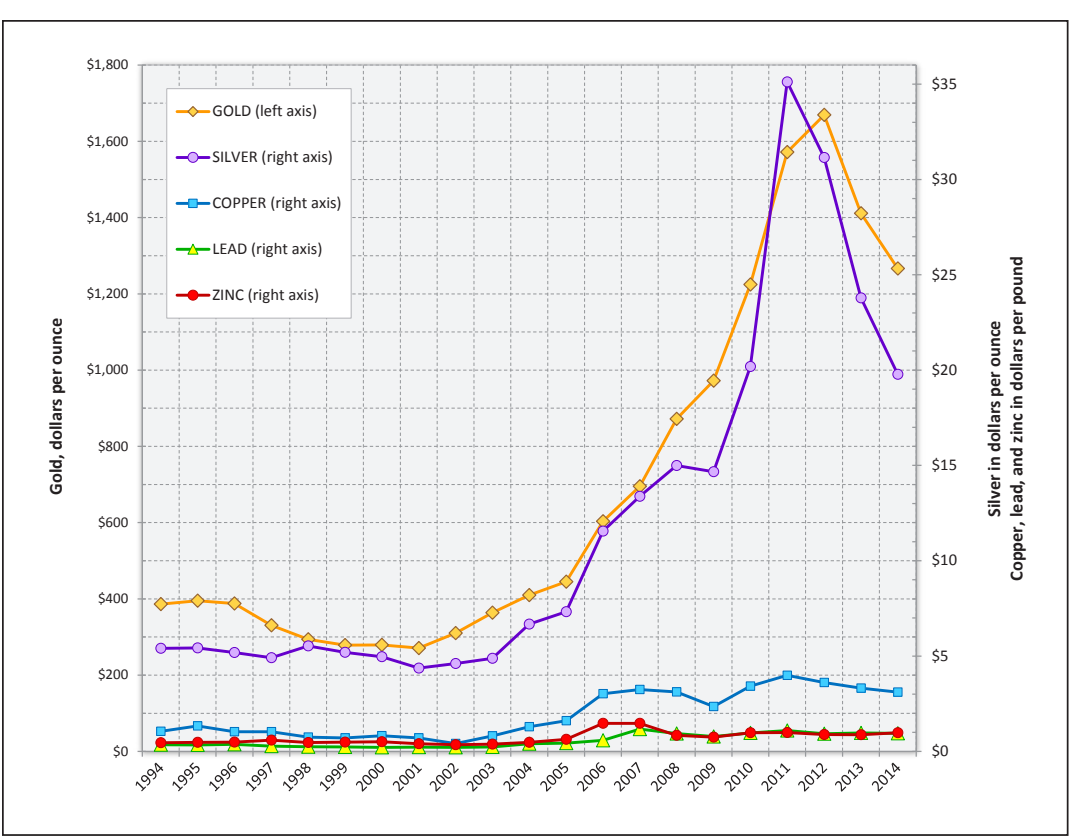

Figure 17. Average annual metal values, 1994-2014. statewide placer gold production dropped to 41,132 ounces, 50 percent of 2013 production and lower than any year since 2005 (table 16). A total of 173 placer operators reported producing gold in 2014, a reduction of 41 percent from 2013. The number of small mines (those producing less than 650 ounces per year) had the largest percentage drop; small mining operations are very sensitive to the price of gold. Conversely, the total output of placer gold is dependent on the number of large mines (those producing in excess of 2,500 ounces of gold). Four large placer operators in 2014 produced 14,085 ounces of gold, 31,641 ounces fewer than the five operators in 2013. This substantial drop in placer output from the larger placer mines is a significant part of the 74,440 ounce decline in gold output from 2013 to 2014 (table 15; fig. 18). Despite the decline from the historic million ounce annual production threshold in 2013, the state is still producing gold at a volume not seen for a century. The currently producing mines have identified resources to maintain the present production level, depending on metal prices, through at least 2020.

Industrial materials production was reported from every region except for the Western region (tables 17-18). The composite value of the rock, sand, and gravel sector is $\$ 24.1$ million based on 2014 reports, only 28 percent of the reported value of $\$ 85.1$ million reported in 2013 (tables 17-18); however, this sector is noted for incomplete reporting of its production. The total estimated volume for industrial materials of 1.67 million tons is for 32 operations; this is significantly different than the nearly 12 million tons reported for 134 operations in 2013 (fig. 19). Total employment in the industrial materials sector is 95 full-time-equivalent jobs in 2014, in comparison to 584 in 2013 . The low 2014 production volume, value, and employment figures are an artifact of reporting shortfalls in an industry that is chronically underreported. Our 2014 numbers should not be used as a reliable gauge of the sector. Other potential gauges of this sector do not indicate such a large drop. The Alaska Railroad reportedly hauled 2.35 million tons of aggregate in 2014, about the same as in 2013; and, based on revised construction forecasts from the Associated General Contractors of Alaska, there was an 8 percent increase in construction spending from 2013 to 2014.

Coal and peat production declined by approximately 100,000 tons (table 13; fig. 20), primarily due to a reduction in coal exports.

The Alaska export value of mineral ores and concentrates, metal ores and concentrates, and coal was $\$ 1.78$ billion in 2014, up 15 percent from 2013 (table 19; fig. 21). Total exports include coppergold concentrates from the Minto Mine in Yukon 


\begin{tabular}{|c|c|c|c|c|c|c|c|c|c|}
\hline Region & 2012 & 2013 & 2014 & 2012 & 2013 & 2014 & 2012 & 2013 & 2014 \\
\hline Northern & 22 & 22 & 4 & 4,576 & 4,897 & 185 & 33 & 48 & 2 \\
\hline Western & 93 & 91 & 65 & 44,037 & 40,438 & 9,873 & 184 & 178 & 139 \\
\hline Eastern Interior & 148 & 140 & 104 & 720,219 & 800,401 & 758,662 & 1,104 & 1,055 & 867 \\
\hline Southeastern ${ }^{c}$ & 4 & 4 & 3 & 138,011 & 173,268 & 176,634 & 659 & 699 & 566 \\
\hline Alaska Peninsula ${ }^{d}$ & 1 & 1 & 0 & 1 & 0 & 0 & 1 & 1 & 0 \\
\hline TOTAL & 317 & 295 & 210 & 921,240 & $1,022,987$ & 948,547 & 2,085 & 2,054 & 1,589 \\
\hline $\begin{array}{l}\text { a } 2014 \text { production inclu } \\
\text { bIncludes recreational } \\
\text { 'Includes numbers in a } \\
\text { dProduction from this }\end{array}$ & $\begin{array}{l}\text {, } \\
\text { numb } \\
\text { ories } \\
\text { ource }\end{array}$ & $\begin{array}{l}\text { ff gold } \\
\text { rators, } \\
\text { ens } \mathrm{Cr} \\
\text { ned wi }\end{array}$ & $\begin{array}{l}\text { hardroc } \\
\text { s, emp } \\
\text { ine, wh } \\
\text { thwest }\end{array}$ & $\begin{array}{l}41,132 \text { ounc } \\
\text { s calculated } \\
\text { netallic prod } \\
\text { on for confid }\end{array}$ & $\begin{array}{l}\text { old from pla } \\
\text { basis of full- } \\
\text { ith a strong } \\
\text { y purposes. }\end{array}$ & $\begin{array}{l}\text { urces. } \\
\text { mployment. } \\
\text { omponent. }\end{array}$ & & & \\
\hline
\end{tabular}

\begin{tabular}{|c|c|c|c|c|c|c|c|c|}
\hline & 2007 & 2008 & 2009 & 2010 & 2011 & 2012 & 2013 & 2014 \\
\hline \multicolumn{9}{|l|}{ Mine Size } \\
\hline Small ${ }^{\mathrm{a}}$ & 153 & 169 & $216^{d}$ & 190 & 271 & 283 & 277 & 159 \\
\hline Medium $^{b}$ & 19 & 24 & 16 & 35 & 20 & 23 & 13 & 10 \\
\hline $\operatorname{Large}^{c}$ & 2 & 2 & 2 & 2 & 6 & 6 & 5 & 4 \\
\hline TOTAL & 174 & 195 & $234^{d}$ & 227 & 297 & 312 & 295 & 173 \\
\hline \multicolumn{9}{|c|}{ Production in Ounces } \\
\hline Small & 19,755 & 19,601 & 23,916 & 17,358 & 22,222 & 24,073 & 18,225 & 14,757 \\
\hline Medium & 23,366 & 27,298 & 20,680 & 23,160 & 20,295 & 29,483 & 18,641 & 12,290 \\
\hline Large & 10,728 & 9,860 & 15,654 & 28,800 & 36,200 & 46,485 & 45,726 & 14,085 \\
\hline TOTAL & 53,849 & 56,759 & 60,250 & 69,318 & 78,717 & 100,041 & 82,591 & 41,132 \\
\hline \multicolumn{9}{|c|}{$\begin{array}{l}\text { a }<650 \text { ounces of gold per year. } \\
\text { b650-2,500 ounces of gold per year. } \\
\text { c }>2,500 \text { ounces of gold per year. } \\
d_{2} 2009 \text { values were revised. }\end{array}$} \\
\hline
\end{tabular}

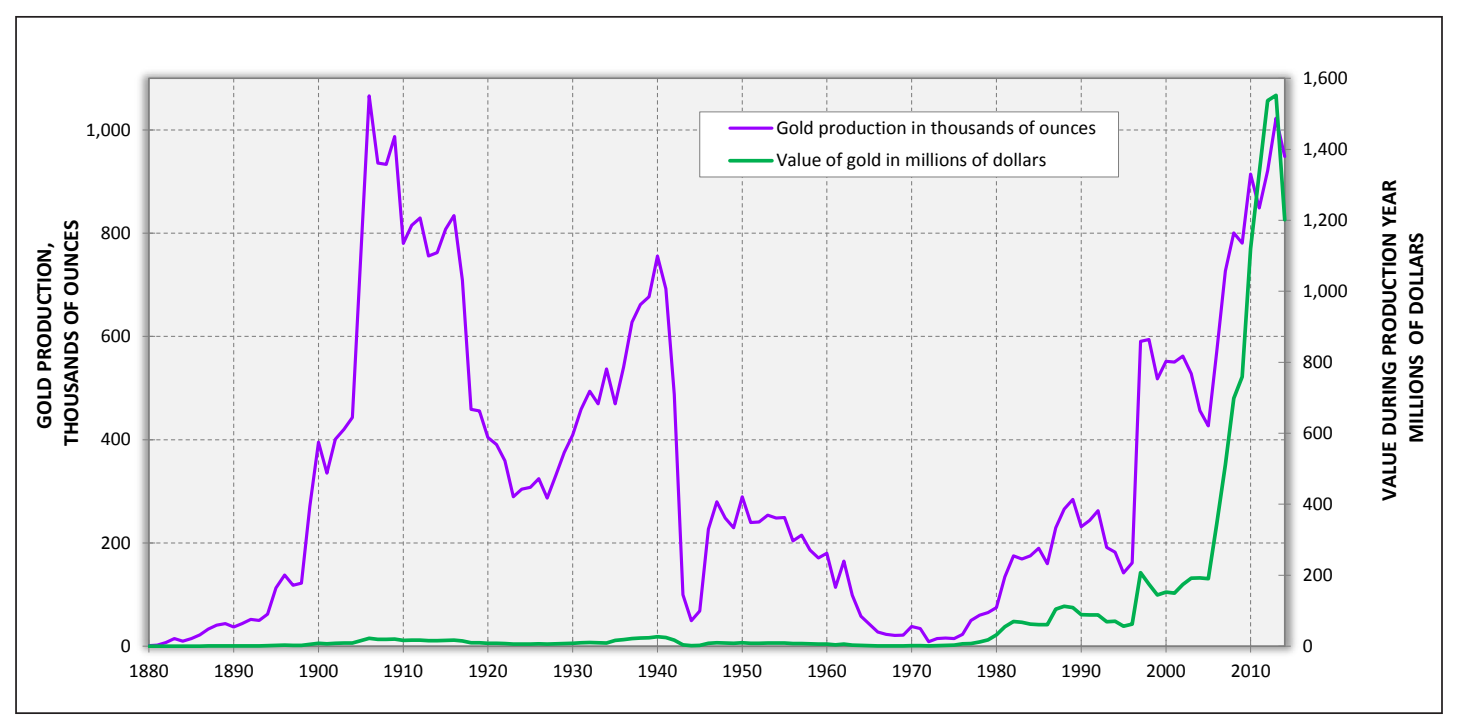

Figure 18. Historical gold production in Alaska, 1880-2014, and corresponding market value. 


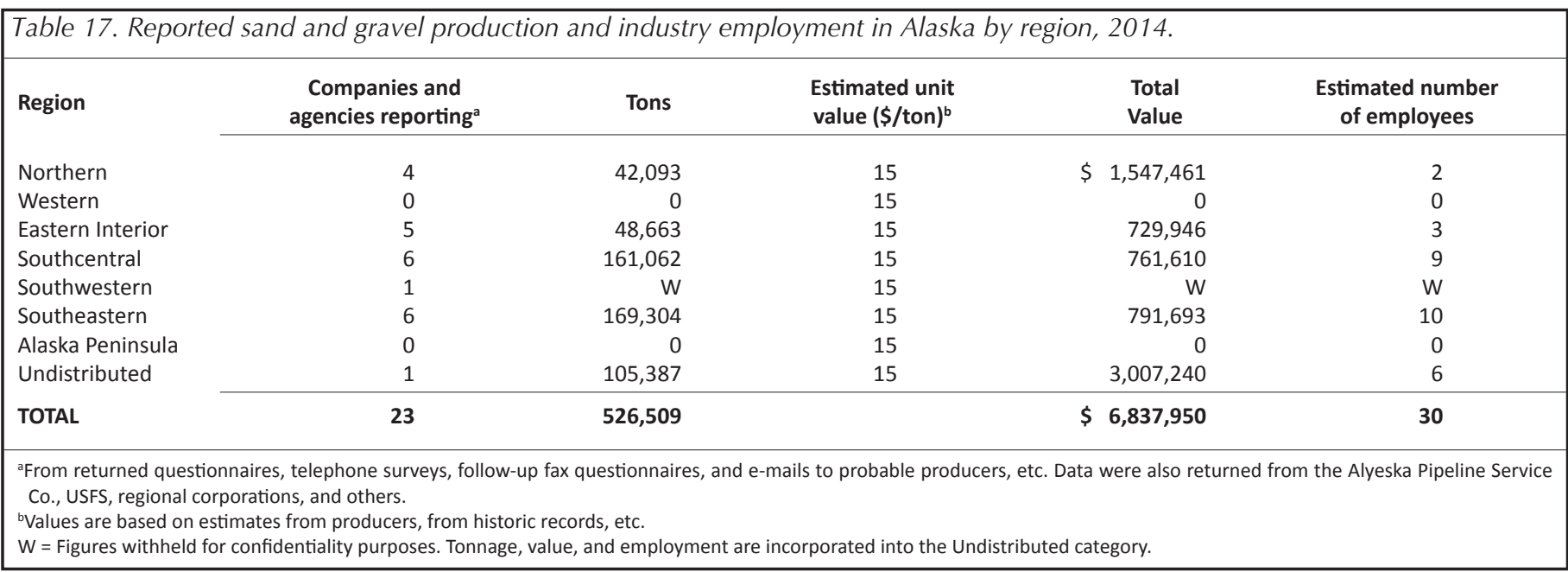

\begin{tabular}{|c|c|c|c|c|c|}
\hline Region & $\begin{array}{l}\text { Companies and } \\
\text { agencies reporting }\end{array}$ & Tons & $\begin{array}{l}\text { Estimated unit } \\
\text { value }(\$ / \text { ton })^{b}\end{array}$ & $\begin{array}{l}\text { Total } \\
\text { value }\end{array}$ & $\begin{array}{c}\text { Estimated number } \\
\text { of employees }\end{array}$ \\
\hline Northern & 1 & 2,701 & 15 & 40,522 & $<1$ \\
\hline Western & 0 & & & & \\
\hline Eastern Interior & 0 & & & & \\
\hline Southcentral & 4 & $1,002,198$ & 15 & $15,032,961$ & 57 \\
\hline Southwestern & 0 & & & & 0 \\
\hline Southeastern & 3 & 142,970 & 15 & $2,144,531$ & 8 \\
\hline Alaska Peninsula & 1 & W & 15 & w & W \\
\hline TOTAL & 9 & $1,147,869$ & & $\$ 17,218,014$ & 65 \\
\hline
\end{tabular}

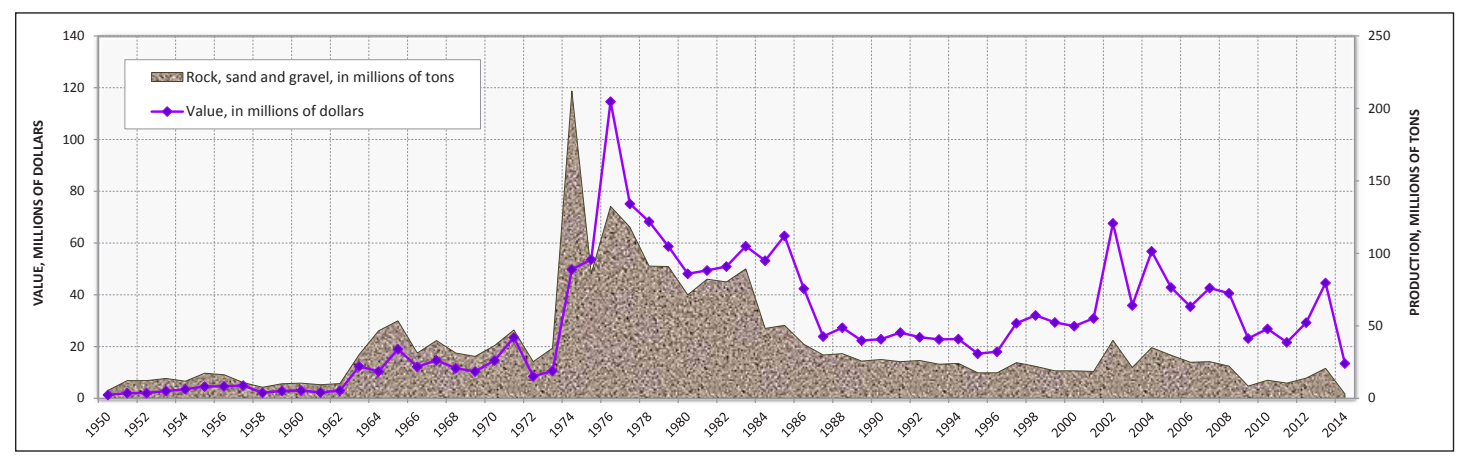

Figure 19. Rock, sand, and gravel production in Alaska, 1950-2014.

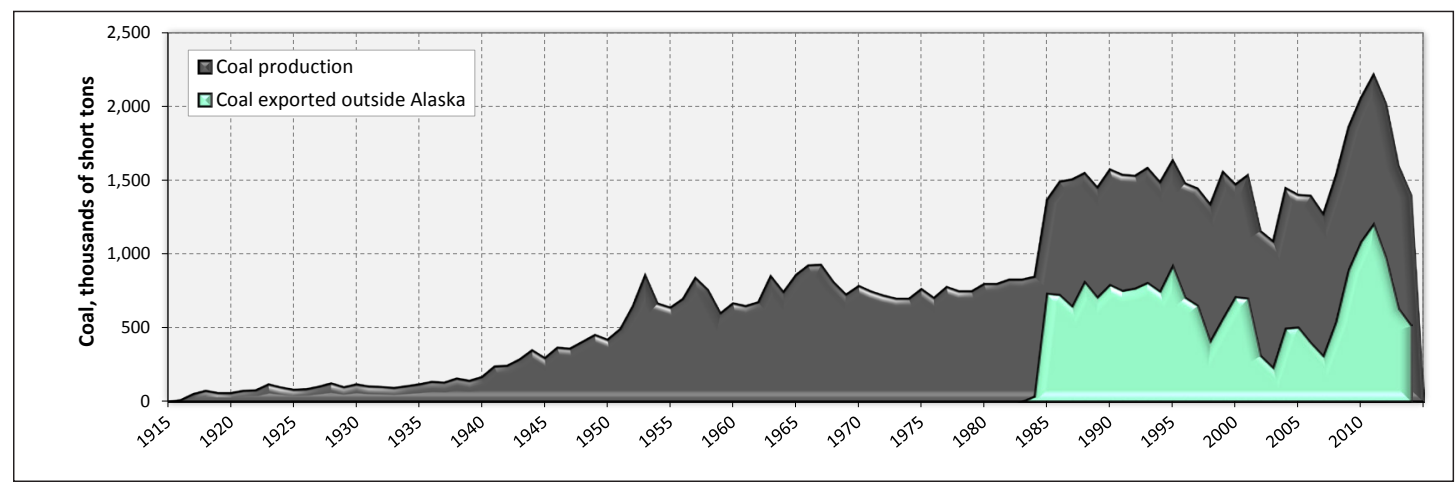

Figure 20. Alaska coal production and exports, 1915-2014. 
Territory, Canada, which were shipped through the AIDEAowned terminal in Skagway. Coal is exported through the Alaska-Railroad-owned Seward coal-loading facility (fig. 20).

Production estimates in this report are compiled from questionnaires returned to DGGS by miners and mining companies, Native organizations, government agencies, municipalities, and service companies. The information returned on questionnaires is supplemented by phone calls, emails, faxes, and information from annual reports, $10-\mathrm{K}$ reports, and news releases by producers. Additional information was derived from State of Alaska Annual Placer Mining Applications (APMAs) submitted to the Division of Mining, Land \& Water and Affidavits of Annual Labor filed with the State Recorder's Office. Appendix B lists Alaska metal producers for 2014.

\begin{tabular}{|c|c|c|c|c|c|}
\hline & $\begin{array}{l}\text { Mineral Ores } \\
\text { and } \\
\text { Concentrates }^{\mathrm{a}}\end{array}$ & $\begin{array}{l}\text { Canada Copper } \\
\text { Ores Through } \\
\text { Skagway Terminal }\end{array}$ & $\begin{array}{l}\text { Precious } \\
\text { Metals }^{c}\end{array}$ & Coal $^{d}$ & $\begin{array}{c}\text { Total Value } \\
\text { of Mineral } \\
\text { Exports }\end{array}$ \\
\hline 1996 & $\$ 249$ & - - & $>\$ 1$ & $\$ 27$ & $\$ 276$ \\
\hline 1997 & 369 & -- & $>\$ 1$ & 26 & 395 \\
\hline 1998 & 317 & - - & $>\$ 1$ & 8 & 325 \\
\hline 1999 & 359 & -- & $>\$ 1$ & 15 & 374 \\
\hline 2000 & 293 & - - & 1 & 16 & 310 \\
\hline 2001 & 329 & - - & 3 & 17 & 349 \\
\hline 2002 & 380 & -- & 47 & 9 & 436 \\
\hline 2003 & 413 & -- & 84 & 4 & 501 \\
\hline 2004 & 505 & - - & 110 & 14 & 629 \\
\hline 2005 & 511 & - - & 132 & 14 & 657 \\
\hline 2006 & 1,094 & - - & 110 & 10 & 1,214 \\
\hline 2007 & 1,269 & 16 & 132 & 5 & 1,406 \\
\hline 2008 & 691 & 103 & 144 & 23 & 858 \\
\hline 2009 & 853 & 64 & 153 & 33 & 1,039 \\
\hline 2010 & 1,336 & 37 & 214 & 25 & 1,575 \\
\hline 2011 & 1,809 & 199 & 267 & 31 & 2,107 \\
\hline 2012 & 1,502 & 169 & 84 & 32 & 1,618 \\
\hline 2013 & 1,495 & 150 & 22 & 27 & 1,543 \\
\hline 2014 & 1,750 & 186 & 11 & 17 & 1,778 \\
\hline \multicolumn{6}{|c|}{$\begin{array}{l}\text { Sources: 1996-2013, U.S. Census Bureau, Origin of Movement Series; 2014, Patricia Eckert, Office of the Governor } \\
\text { aHS } 26 \text { Mineral Ores: Zinc ores and concentrates, lead ores and concentrates, copper ores and concentrates, silver } \\
\text { ores, gold ores and concentrates, zirconium ore (only in 2009), and miscellaneous ores } \\
\text { bValue of Canada copper ores moving through Skagway that are included in Mineral Ores and Concentrates values } \\
\text { cHS } 71 \text { Precious Metals: Gold doré, precious stones, and wrought jewelry } \\
\text { dHS } 27 \text { Coal }\end{array}$} \\
\hline
\end{tabular}

Figure 21. Alaska international mineral export values (millions of dollars), 19962014.

\section{NORTHERN REGION}

Seven companies reported development expenditures totaling $\$ 45.1$ million in the Northern region in 2014, with estimated employment equivalent to 112 full-time jobs. The reported development included work at Red Dog Mine, at the Chandalar placer project, and in the Koyukuk-Nolan Creek mining district and included capitalized stripping costs, equipment purchases, construction, and infrastructure development.

The production value for the Northern region totals $\$ 1.70$ billion, dominated by Red Dog. The region had estimated employment equivalent to 451 full-time jobs at a total of ten operations including Red Dog, four placer mines, and five rock, sand, and gravel quarries. One operator in this region also produced peat. Placer mining in the region produced 185 ounces of gold and quarries and gravel pits produced 44,794 tons of rock, sand, and gravel.

\section{Red Dog Mine}

Red Dog Mine (photo 11) is one of the world's largest zinc mines, both in terms of resources (appendix F) and annual zinc production (table 20), producing lead and zinc concentrates that are trucked to a port on the coast for shipping during the summer. The resources at Red Dog represent 4 percent of the world's and 95 percent of domestic zinc reserves. Red Dog dominates Alaska's mineral production value, as it has for a quarter century, accounting for approximately 51 percent of the entire value of Alaska's mineral production in 2014 . The mine is operated by Teck Alaska Inc., and is 100 percent owned and operated by Teck Resources Ltd., under a partnership agreement with NANA Regional Corp.

The deposit was discovered in the late 1960s by pilot and prospector Bob Baker. Following the Alaska Native Claims Settlement Act (ANCSA) of 1971 , it came under ownership of NANA. NANA 


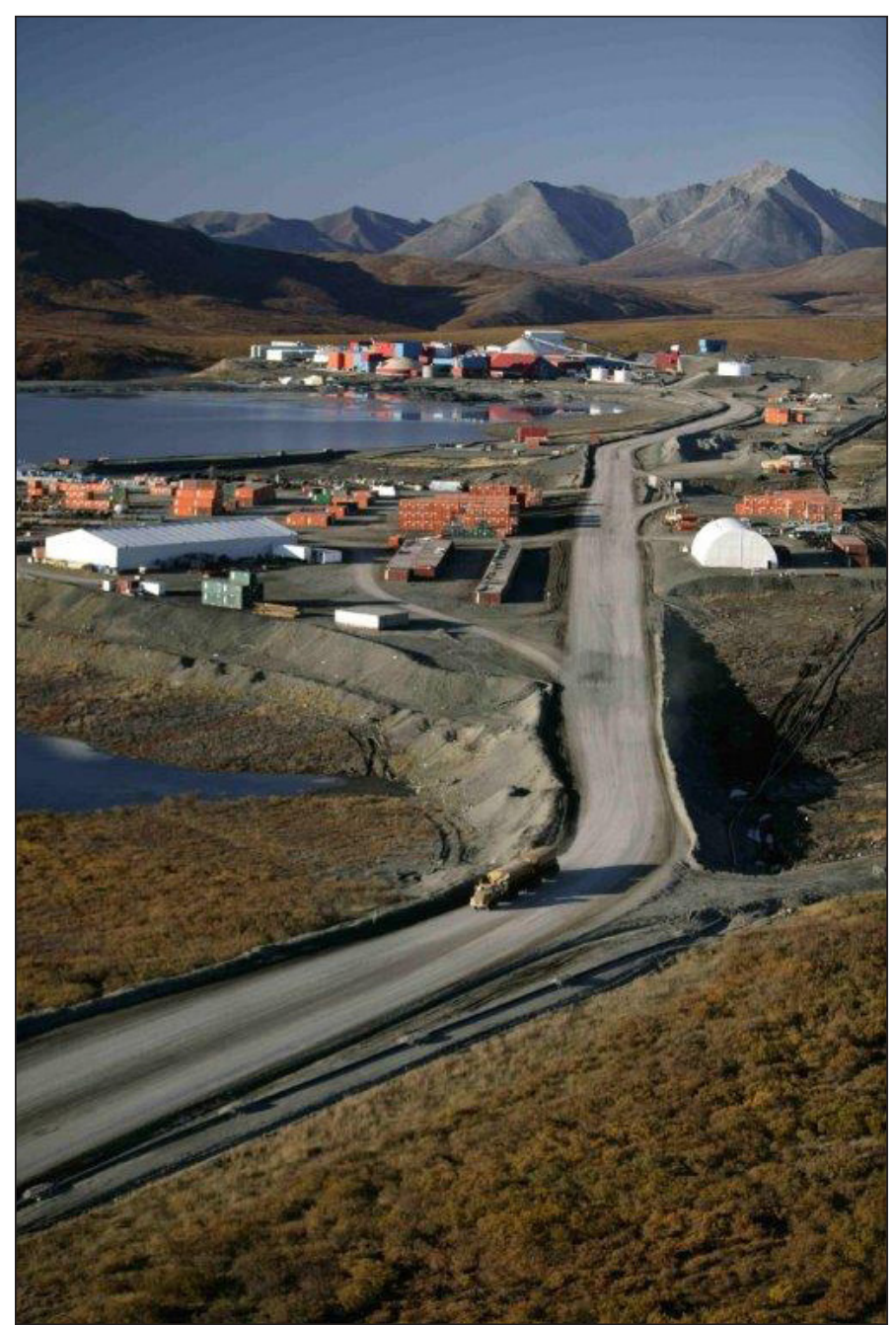

Photo 11. Red Dog Mine site facilities. The dormitory complex is in the foreground and the mill complex is in the background; a covered concentrate-hauling truck can be seen departing the mine en route to the port facilities. The Red Dog mine employs 639 staff and contractors and produced more than 656,971 tons of zinc in 2014. Photo provided by Teck Alaska Inc.

shareholders decided to move forward with a plan to develop the deposit at the 1980 NANA Annual Shareholder Meeting. In 1982 an operating agreement was reached between NANA and Cominco, now Teck. The operating agreement created mutual benefits: for Teck it created what has become one of the company's most profitable operations since mining began, and NANA has received $\$ 1$ billion in proceeds from the mine, of which more than $\$ 617$ million has been shared with other Alaska Native regional and village corporations under section 7(i) of ANCSA.

Red Dog comprises three deposits: Main, Aqqaluk, and Qanaiyaq. Development of the Aqqaluk deposit began in May 2010 and production commenced three months later. The Red Dog Main pit was exhausted in 2012 and all current production is from the Aqqaluk deposit. The Qanaiyaq deposit remains undeveloped. The deposits are sedimentary-hosted exhalative lead-zinc sulfide deposits in thrust-fault slices that result in relatively flat-lying, lens-shaped ore bodies. The deposits are hosted in Mississippian- to Pennsylvanian-age marine clastic rocks and lesser chert and carbonate rocks. The sulfide mineralization consists of semi-massive to massive sphalerite, pyrite, marcasite, and galena with massive, fragmental, veined and, rarely, sedimentary layering textures. Massive barite rock is common in and above the sulfide deposits.

The mine is a conventional open pit that is mined using a drill, blast, shovel, and truck cycle. A large, managed stockpile is used to blend different ore types prior to milling. The mill employs conventional grinding and sulfide flotation methods to produce zinc and lead concentrates. Tailings storage and waste disposal areas have adequate capacity for the planned mine life. Contaminated water from the mine site is stored in the tailings impoundment and is seasonally discharged through a water treatment plant. Outgoing zinc and lead concentrates and incoming fuel and supplies are transported through the AIDEA-owned DeLong Mountain Transportation System (DMTS), which includes a 52 mile road, concentrate and fuel storage, and shallow-water port facilities. Since inception AIDEA has received more than $\$ 400$ million in user fees for the DMTS; the port has an approximately 100-day annual shipping season. Concentrates are lightered on specially designed barges to deep-water ore carriers. Concentrate hauling and lightering are temporarily halted in the presence of migratory land and sea mammals to avoid altering migratory habits and disrupting the local subsistence lifestyle.

In 2014 Red Dog had 639 full-time-equivalent jobs (table 20), devoted to both production and development; 63 percent of the company payroll goes to NANA shareholders and 75 percent of employees are Alaska residents. Teck reported 1 million hours without a lost-time incident in 2014. Teck also reported 2014 capitalized stripping costs of $\$ 40.9$ million at Red Dog. In 2014, thanks to softer barite-rich ore, the mine achieved a record annual mill throughput of 4.74 million tons, record zinc-metal production of 656,971 tons, and record total metal (lead and zinc) production of 792,003 tons (table 20). The port had a good shipping season, loading 24 concentrate ships, one more than planned. Red Dog record zinc output, combined with 17 percent higher realized zinc prices, contributed to the Teck zinc unit earning a 50 percent higher gross profit over 2013. As of the end of 2014 Teck reported 58.2 million tons of proven and probable reserves at Red Dog Mine with an average grade of 16.5 percent zinc, 4.3 percent lead, and 2.34 ounces of silver per ton in a total identified resource of 58.5 billion tons at 4.3 percent lead, 16.5 percent zinc, and 2.33 ounces of silver per ton (appendix F). Teck projected that 2015 Red Dog production will be approximately 10 percent less than in 2014 . 


\begin{tabular}{|c|c|c|c|c|c|c|c|c|c|}
\hline \multicolumn{10}{|c|}{ Table 20. Red Dog Mine production statistics, 1989-2014. } \\
\hline & \multirow{2}{*}{$\begin{array}{l}\text { Tons } \\
\text { Milled }\end{array}$} & \multicolumn{3}{|c|}{ Ore Grade } & \multirow{2}{*}{$\begin{array}{l}\text { Total Tons } \\
\text { Concentrate } \\
\text { Produced }^{\mathrm{b}}\end{array}$} & \multirow{2}{*}{$\begin{array}{c}\text { Contained } \\
\text { Tons } \\
\text { Zinc }\end{array}$} & \multirow{2}{*}{$\begin{array}{l}\text { Contained } \\
\text { Tons } \\
\text { Lead }\end{array}$} & \multirow{2}{*}{$\begin{array}{l}\text { Million } \\
\text { Ounces } \\
\text { Silver }^{c}\end{array}$} & \multirow{2}{*}{ Employees } \\
\hline & & $\begin{array}{l}\text { Zinc } \\
(\%)\end{array}$ & $\begin{array}{l}\text { Lead } \\
(\%)\end{array}$ & $\begin{array}{c}\text { Silver } \\
\text { (oz/ton) }\end{array}$ & & & & & \\
\hline 1989 & 33,300 & 20.4 & 7.6 & 3.6 & 8,532 & -- & -- & - - & 228 \\
\hline 1990 & 996,700 & 26.5 & 8.5 & 3.6 & 443,600 & 191,981 & 31,187 & 1.6 & 350 \\
\hline 1991 & $1,599,300$ & 22.5 & 6.6 & 2.8 & 521,400 & 234,510 & 43,815 & 1.46 & 331 \\
\hline 1992 & $1,582,000$ & 19.9 & 6.0 & 2.9 & 474,900 & 231,363 & 15,960 & 1.38 & 349 \\
\hline 1993 & $1,874,600$ & 18.4 & 5.7 & 2.8 & 539,800 & 255,149 & 24,788 & 1.51 & 376 \\
\hline 1994 & $2,339,500$ & 18.8 & 5.7 & 2.8 & 658,000 & 328,160 & 32,775 & 1.84 & 391 \\
\hline 1995 & $2,485,900$ & 19.0 & 5.8 & 2.8 & 753,600 & 358,676 & 55,715 & 3.62 & 397 \\
\hline 1996 & $2,312,600$ & 18.7 & 5.0 & 2.8 & 765,300 & 357,680 & 65,886 & 4.3 & 417 \\
\hline 1997 & $2,127,000$ & 20.3 & 5.2 & 2.9 & 799,400 & 373,097 & 69,284 & 4.27 & 479 \\
\hline 1998 & $2,752,587$ & 21.4 & 5.2 & 2.7 & $1,015,773$ & 490,461 & 80,193 & 5.2 & 466 \\
\hline 1999 & $3,282,788$ & 21.3 & 5.2 & 2.7 & $1,207,160$ & 574,111 & 97,756 & 6.21 & 539 \\
\hline 2000 & $3,365,508$ & 21.0 & 4.7 & 2.5 & $1,211,539$ & 585,030 & 91,557 & 5.84 & 536 \\
\hline 2001 & $3,560,430$ & 19.8 & 5.0 & 2.5 & $1,215,837$ & 570,980 & 105,000 & 5.9 & 559 \\
\hline 2002 & $3,489,600$ & 21.1 & 5.4 & 2.7 & $1,366,480$ & 637,800 & 118,880 & 6.75 & 560 \\
\hline 2003 & $3,476,689$ & 21.7 & 6.2 & 3.1 & $1,410,892$ & 638,569 & 137,679 & 7.7 & 388 \\
\hline 2004 & $3,249,613$ & 22.0 & 6.0 & 3.0 & $1,337,545$ & 610,900 & 128,970 & 7.22 & 508 \\
\hline 2005 & $3,402,831$ & 21.7 & 5.6 & 3.0 & $1,330,717$ & 626,112 & 112,766 & 1.97 & 449 \\
\hline 2006 & $3,569,280$ & 20.6 & 6.1 & 3.0 & $1,378,384$ & 614,538 & 136,135 & 7.62 & 457 \\
\hline 2007 & $3,726,910$ & 20.2 & 6.1 & 3.1 & $1,428,014$ & 633,511 & 146,152 & 11.55 & 459 \\
\hline 2008 & $3,306,934$ & 20.1 & 6.0 & 3.1 & $1,273,885$ & 567,911 & 135,143 & 7.5 & 475 \\
\hline 2009 & $3,729,119$ & 20.9 & 5.9 & 3.1 & $1,445,870$ & 642,096 & 144,954 & 8.12 & 413 \\
\hline 2010 & $3,937,456$ & 18.2 & 5.4 & 3.1 & $1,300,694$ & 593,043 & 121,144 & 6.78 & 550 \\
\hline 2011 & $4,048,000$ & 19.1 & 5.0 & 3.0 & $1,182,060$ & 572,208 & 84,033 & 5.19 & 586 \\
\hline 2012 & $3,941,000$ & 18.2 & 4.6 & 3.0 & $1,134,415$ & 529,157 & 95,282 & 5.89 & 530 \\
\hline 2013 & $4,243,899$ & 17.0 & 3.9 & NA & $1,271,221$ & 607,704 & 106,594 & 6.1 & $550^{d}$ \\
\hline 2014 & $4,739,302$ & 16.6 & 4.4 & NA & $1,409,511$ & 656,971 & 135,032 & 7.56 & $639^{d}$ \\
\hline Total & $77,172,846$ & & & & $26,884,529$ & $12,481,718$ & $2,316,679$ & 133.08 & \\
\hline \multicolumn{10}{|c|}{$\begin{array}{l}\text { aRevised slightly from Special Report } 51 \text {, Alaska's Mine } \\
\text { 'Totals for years } 1990 \text { through } 1995 \text { include bulk conce } \\
\text { 'Estimate calculated at } 56 \text { ounces per ton of lead meta } \\
\text { of ore for } 2007 \text {; estimated as proportional with incre } \\
\text { dValue reported by Department of Natural Resources } \\
--=\text { No concentrate produced } \\
\text { NA = not available }\end{array}$} \\
\hline
\end{tabular}

\section{Chandalar Gold Project}

The Chandalar Gold project is operated by Goldrich NyacAu Placer LLC, a 50/50 joint venture between the Goldrich Mining Co. and NyacAu LLC to develop commercial-scale gold mining on the Little Squaw placer deposit. Expenditures of $\$ 3.6$ million were directed toward plant relocation to a lower and broader part of the valley, construction of new water ponds, and build-out of the new, expanded plant, which is expected to be completed in 2015. Full capacity of the feeder is expected to be approximately 600 bank cubic yards per hour and will be realized as additional components are added through 2016. Startup of the plant and initial gold production is planned for summer 2015.

\section{WESTERN REGION}

Fifteen lode and placer projects in the Western region reported development expenditures totaling $\$ 12.4$ million, nearly 63 percent less than in 2013. Employment equivalent to 16 full-time jobs was associated with development. Two projects reported expenses greater than $\$ 1$ million each: Phoenix Offshore
Mining Inc. in the Nome offshore lease tract and Mystery Creek Resources at Nixon Fork Mine northwest of McGrath.

Phoenix Offshore Mining reported spending $\$ 6.82$ million to build and operate two elevated work platforms (jack-up dredges) (photo 12). Phoenix also conducted test mining and concurrent reclamation on a portion of the leases during the 2014 season as a proof of concept. Phoenix believes that the jack-up dredges will allow safe and environmentally sound mining through 92 percent of the mining season, and can continue to operate through periods of high surf and weather conditions that idle traditional offshore dredges.

In July Waterford Global Value LP took over full ownership of Mystery Creek Resources Inc., the owner of the Nixon Fork Mine, from Fire River Gold Corp. as a result of the 2013 Fire River Gold default on a credit agreement. Mystery Creek Resources has full-time personnel at the mine site and expended $\$ 1.75$ million on environmental monitoring, security, care, and maintenance during 2014. The Nixon Fork deposit is a gold-copper skarn with multiple individual ore bodies in the margin of a Late Cretaceous quartz monzonite stock; the mine 


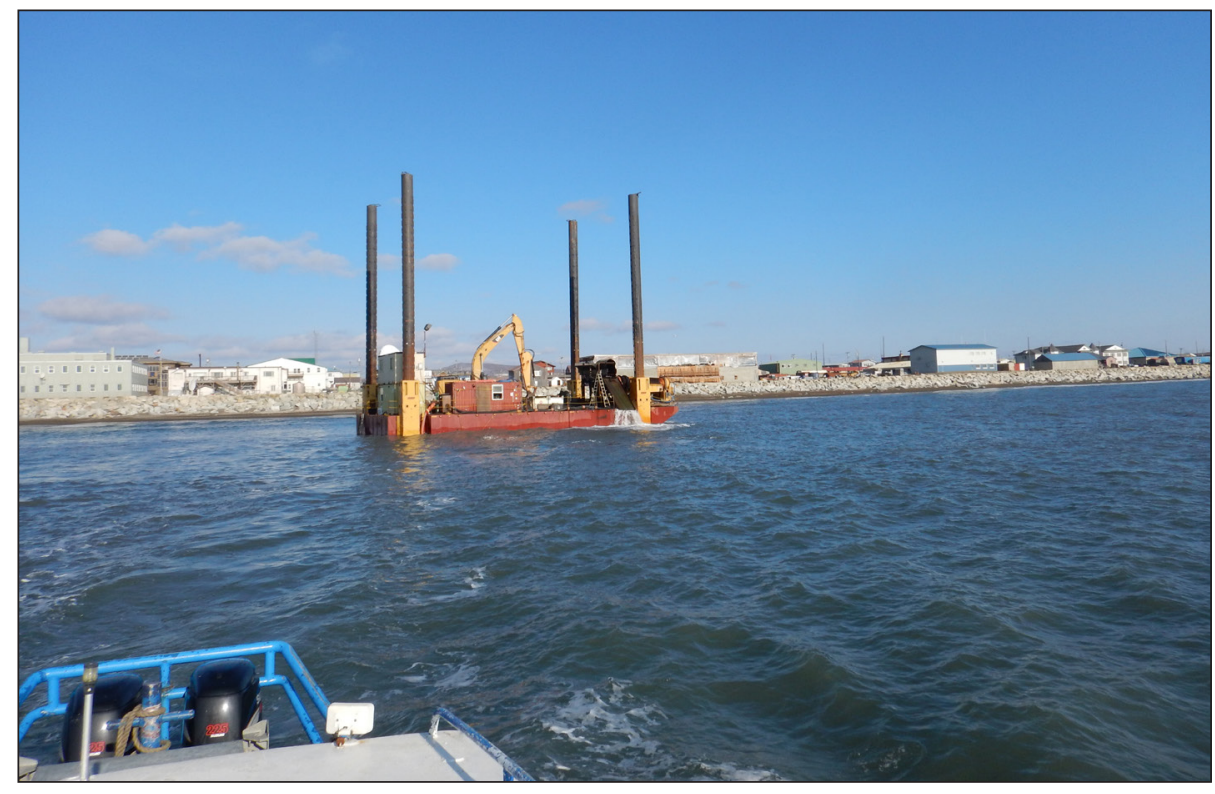

Photo 12. One of two "elevated work platforms", or jack-up dredges, operated by Phoenix Offshore Mining Inc. in the Nome offshore lease area in western Alaska. Photo provided by Rob Retherford, Alaska Earth Sciences Inc.

has produced slightly more than 198,000 ounces of gold, mostly from 1995 until 1999. A total identified resource containing 338,430 tons at 0.491 ounce of gold per ton remains at the mine (appendix F).

Placer gold production of 9,873 ounces was reported by 55 operators in the Western region, with 7,666 of the ounces coming from 45 operators in the Nome and Hughes mining districts. One of the operators is considered to be a large operation (producing in excess of 2,500 ounces), while 51 of the operators produced less than 650 ounces of gold each. Total value of the production is estimated at $\$ 12.5$ million. Employment by the placer operators is estimated to be equivalent to 139 full-time jobs.

No industrial minerals development or production was reported in the Western region; this is likely not a true reflection of activity. In 2013 sand and gravel production equivalent to 1.38 million tons was reported by 15 operators.

\section{EASTERN INTERIOR REGION}

Construction and other capital expenditures credited to the Eastern Interior region in 2014 totaled just less than $\$ 167.0$ billion, exclusive of coal expenditures, and was 7 percent less than in 2013. Employment devoted to development in the region is estimated to be equivalent to 231 full-time jobs. Development activities were reported for 43 projects in 2014, more than twice as many as in 2013, including placer, lode gold, and coal projects. Reported development work in the region was dominated by hardrock gold projects, accounting for 98 percent of the expenditures and 95 percent of the estimated employment. Industrial materials development work in 2014 in the region was reported confidentially.

The 2014 value of production in the Eastern Interior region is estimated to be $\$ 1.014$ billion, 22 percent less than in 2013; the Eastern Interior is the second most productive region of the state with 31 percent of the total value. The loss of production value is due to lower gold prices combined with reduced gold output, a reduction in coal exports, and a 97 percent reduction in reported industrial minerals production. Employment dedicated to minerals production in the region is estimated at 984 full-time-equivalent positions at a total of 98 reporting operations. As in previous years, of the seven geographic regions used for this report, the Eastern Interior region again had the largest number of mining operations and highest employment during 2014.

Fort Knox Mine was the largest gold producer in the region, followed by Pogo Mine. Total Eastern Interior region gold production was an estimated 758,662 ounces, with 29,230 ounces coming from placer mines. A total of 90 placer mines reported production, 80 of which are considered small operators that produced less that 650 ounces each, and three are large operations, producing in excess of 2,500 ounces each. Estimated placer mining employment in the region is equivalent to 92 full-time jobs.

Sand and gravel production in 2014 was reported to be only 48,663 tons from five operators, in contrast to 2013 when 45 operations reported an estimated 2.75 million tons. There was no reported rock production in 2014; in 2013, six operators reported 238,537 tons of rock production. Total estimated employment in the Eastern Interior industrial minerals sector during 2014 was only equivalent to three full-time jobs. The Tanana River Alaska Railroad crossing was completed in summer 2014, with about half of the bridge substructure and south bank stabilization constructed during $2014^{16}$. The project used significant amounts of rock, sand, and gravel, with 9,000 truckloads of riprap, and 612,000 cubic yards of concrete and embankment ${ }^{17}$. Clearly, the Eastern Interior industrial minerals sector is underreported for 2014 .

\footnotetext{
${ }^{16}$ Tanana River Crossing; Northern rail extension phase one fact sheet: http://alaskarailroad.com/Portals/6/pdf/projects/2012 0104 NREPh1 Tanana River Bridge FS PROJ.pdf

${ }^{17}$ Alaska's longest bridge completed across the Tanana River, Alaska Dispatch News, August 5, 2014 http://www.adn.com/print/ article/20140805/alaskas-longest-bridge-completed-across-tanana-river [9/14/2015 12:35:48 PM]
} 


\section{Fort KNOX Mine}

Fort Knox Mine (photo 13), operated by Fairbanks Gold Mining Inc., a wholly-owned subsidiary of Kinross Gold Corp., is approximately 25 highway miles northeast of Fairbanks, on primarily State of Alaska and private lands in the Fairbanks North Star Borough. Fort Knox Mine is an open-pit, truck-andshovel operation using carbon-in-pulp (CIP), heap leach, and gravity processes to recover gold. Major Fort Knox Mine facilities include the open-pit mine, mill, administrative facilities, tailings storage facility, water storage reservoir, and the Walter Creek heap leach facility. Power is supplied from the regional grid via a 29-mile-long power line.

In 1913, at what is now the Fort Knox mine, Edward Voght prospected a bismuth-bearing gold-quartz vein on the ridge between Melba and Monte Cristo creeks. A caved shaft and ruins of a mill were on the site in 1949, suggesting that early mining had taken place. The modern deposit was discovered in 1987, when a geologist walking behind a bulldozer picked up a piece of granite containing visible gold; this discovery was followed by an extensive exploration program by Fairbanks Gold Ltd. through various joint-venture partners. By 1992 most of the initial exploration had been completed and development had begun; the deposit had a proven resource of 4.1 million ounces of gold, and AMAX Gold Inc. had acquired all the interests in Fairbanks Gold. The mine was originally permitted in 1994 and has operated 24 hours a day, 365 days a year since production began in November 1996. Kinross Gold Corp. acquired 100 percent interest in the mine in 1998. The Walter Creek heap leach facility was commissioned in 2009; to date 132.9 million tons have been placed on the heap facility and 601,885 ounces of gold have been recovered. Late in 2013 the 6 millionth ounce of gold was poured. Total deposit size, including production and total identified resource, as of December 2014, is 8.93 million ounces of gold.

The deposit is hosted in the multiphase Fort Knox pluton, with gold occurring as grains ranging from smaller than $0.1 \mathrm{~mm}$ up to $2 \mathrm{~mm}$ on the margins of stockwork quartz veins, veinlets, and quartz-filled shears. The sulfide minerals are rare, less than 0.1 percent, consisting mainly of bismuthinite and minor arsenopyrite as well as several varieties of bismuth-tellurium minerals. There is close geochemical association between gold, bismuth, tellurium, and molybdenum. The pluton and alteration are coeval at approximately 92 million years old. The deposit is oxidized to the depth of drilling.

Fort Knox reported capital expenditures of $\$ 85.2$ million during 2014. Phase 8 pit expansion stripping was initiated; this is the final currently planned expansion of the pit to the west. Expansion of the Walter Creek heap leach included completion of stage 4 and initiation of stage 5 lift, which was 20 percent complete by the end of the year, and completed construction of a barren solution booster pump station. Construction of a 25 foot raise of the tailing storage facility dam was begun, with an 11 foot raise completed by year end; this effort is part of a total 52 foot raise that was started in 2011 and will continue through 2015 to accommodate production to the currently planned end of the mine life (photo 14). The tailings dam was able to capture and retain all runoff from record rainfall experienced during 2014.

In 2014 Fort Knox mined 49.24 million tons of ore and waste from the Fort Knox pit, with an average production rate of 134,900 tons per day. The 2014 mill throughput was 14.9 million tons, and 28.9 million tons were added to the Walter Creek heap leach. Combined 2014 gold recovery from the mill and heap leach was 387,285 ounces (table 21). At the end of 2014 the total identified resource is 311.7 million tons at 0.013 ounce per ton, containing 2.5 million ounces of gold (appendix F); within that resource there are sufficient reserves, 180.6 million tons at 0.016 ounce per ton gold, to carry the current mine plan into 2019. Fort Knox projects a total mill throughput for 2015 of 14.7 million tons complemented with placement of

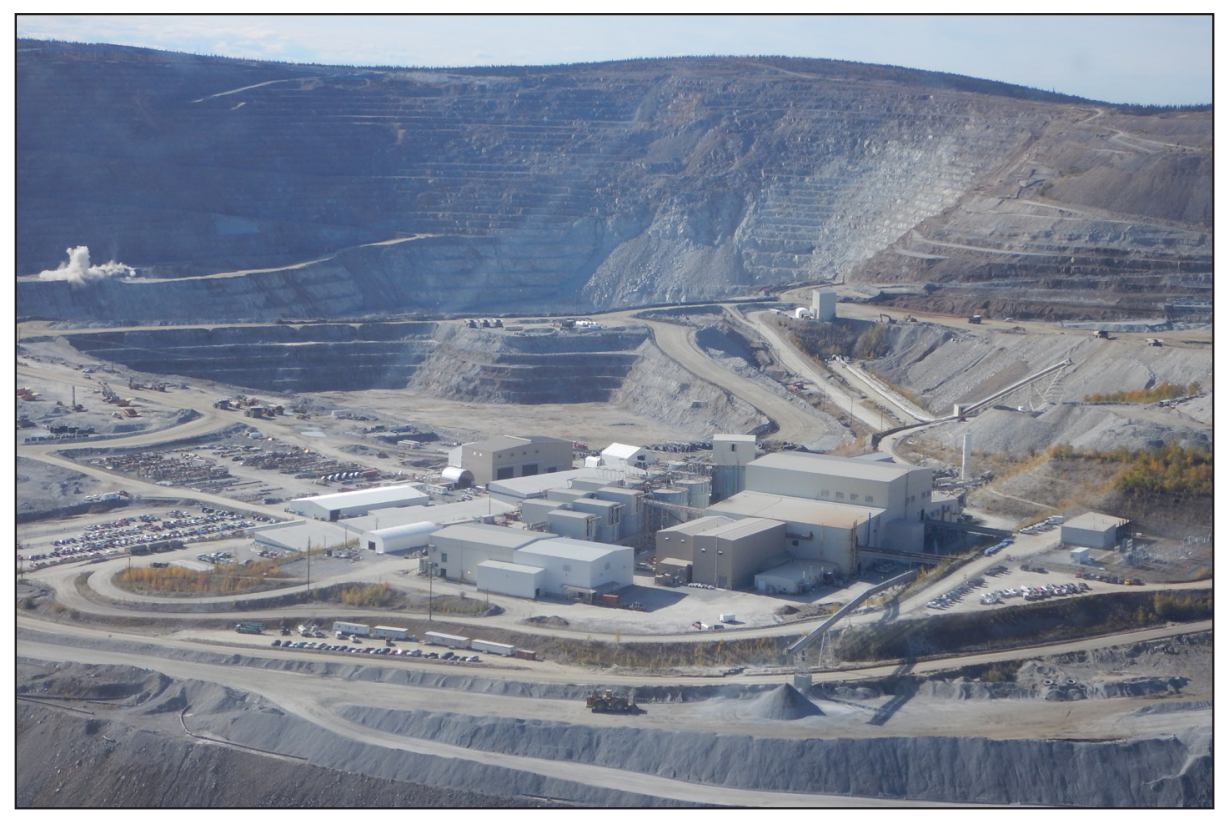

Photo 13. Overview of Fort Knox mine, 25 miles northeast of Fairbanks, in east-central Alaska. Operated by Fairbanks Gold Mining Inc., a Kinross Gold Corp. subsidiary, Fort Knox produced 387,285 ounces of gold from both carbon-in-pulp milled ore and heap-leach ore in 2014. Photo provided by Kinross Fort Knox. 
30.0 million tons on the heap leach, and anticipates recovery of 390,657 ounces of gold from the combined processes.

Total employment at Fort Knox is reported at 649 full-timeequivalent positions. In May the operation achieved 2 million safe hours worked; several of the working groups have multiple years without a lost-time incident.

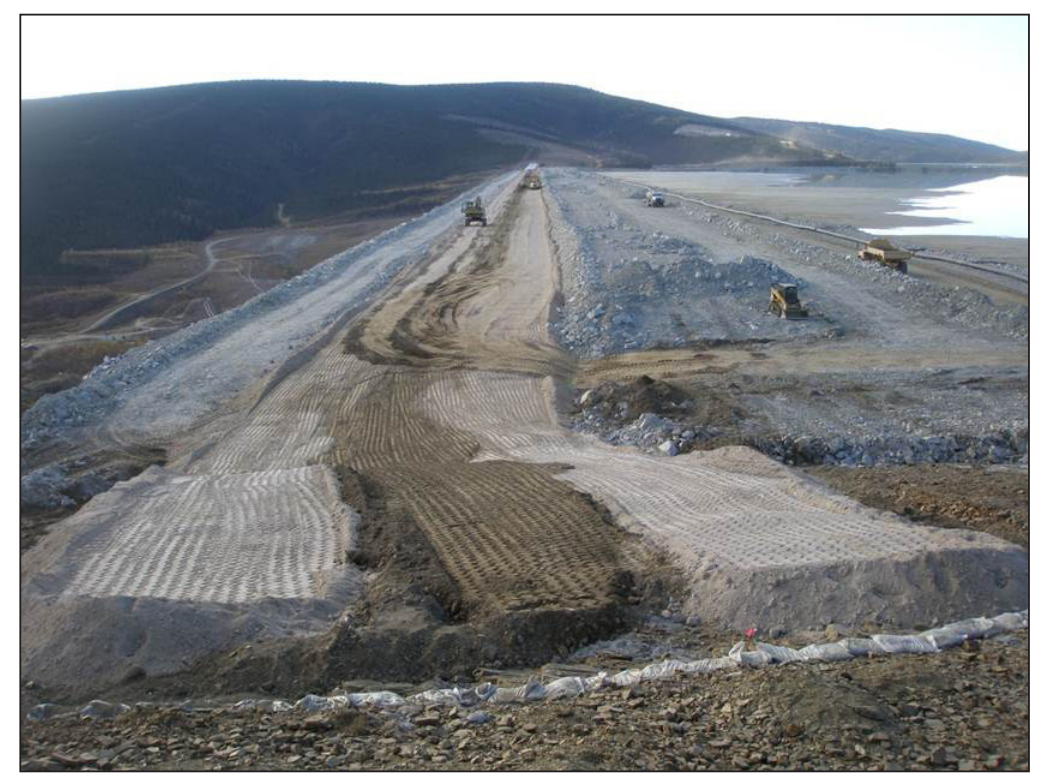

Photo 14. Construction at the Fort Knox tailings storage facility during 2014. Kinross-Fort Knox completed an 11-foot raise of the dam during 2014. Photo provided by Kinross-Fort Knox.

\section{Pogo Mine}

The Pogo Mine (photo 15) is 38 miles northeast of Delta Junction on land owned by the State of Alaska. Access to the mine is via a 49 mile all-season road from the Richardson Highway. Sumitomo Metal Mining Pogo LLC (SMM Pogo) operates Pogo Mine on behalf of owners Sumitomo Metal Mining Co. Ltd. (85 percent) and Sumitomo Corp. (15 percent). The major Pogo Mine facilities include the Pogo underground mine, surface mill, dry stack tailings facility, water management systems, administrative facilities, an upper camp, and a lower recreation area and catering facilities that can accommodate 453 people. Power is supplied from the regional grid via a 50-mile-long transmission line that parallels the access road.

Very little gold prospecting or mining had been carried out in the immediate Goodpaster area until a regional stream-sediment sampling program identified anomalous gold, arsenic, and tungsten in the Pogo area in 1991. Follow-up sampling from 1991 through 1994 outlined a 1-square-mile area with greater than $100 \mathrm{ppb}$ gold in soils above what became the Liese zone of the Pogo mine. Three exploration drill holes penetrated the Liese zone in 1994; by 1999, drilling had delineated the three stacked veins, Liese 1-3, identified a resource of 5.6 million ounces of gold, and an exploration decline had been driven to access the ore zone for a bulk sample and to provide platforms for definition drilling. The

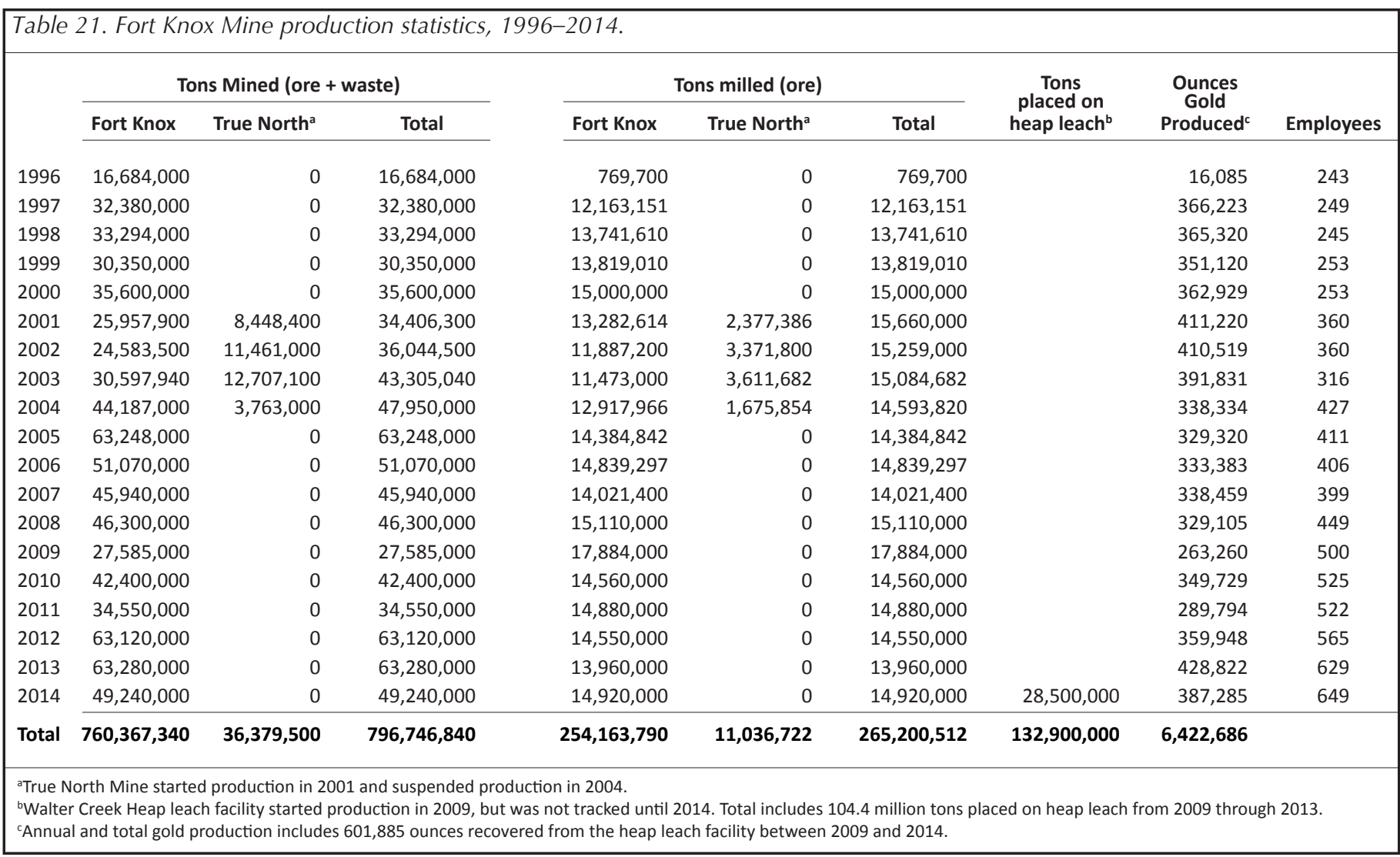


mine was permitted in 2003, initiated production in 2006, and has operated continuously, 24 hours a day, 365 days a year since. Until 2009, the Pogo project was a joint venture between Teck Resources Corp., Sumitomo Metal Mining, and Sumitomo Corp., with Teck as the operator. Teck Resources sold its interest in the mine in July 2009 and SMM Pogo became the operator. In 2009, exploration drilling discovered the East Deep zone, an apparent fault offset of the Liese zone north of the mine and mill facilities; continued exploration drilling has defined the ore body and in 2013 the new 2150 Portal was completed to access the East Deep zone. As of the end of 2014 the Pogo deposit had a total of nearly 7.32 million ounces of gold, including past production and identified resources.

The Pogo deposit consists of three distinct zones: the Liese, East Deep, and North Zone vein systems. The Liese and East Deep consist of stacked, shallow-dipping veins, whereas the North Zone veins are steep and could be feeders to the Liese and East Deep. Individual veins range from 0 to 65 feet thick and have a variety of quartz vein filling and replacement textures, suggesting multiple episodes of mineralization. Gold occurs as 1-25 micron grains in arsenopyrite, along fractures, and as inclusions in native bismuth and other gold-lead-bismuth-tellurium minerals. The age of the mineralization overlaps with nearby granitic intrusions at around 104 million years. There is disagreement over the origin of the veins, with evidence for both orogenic-vein and deep-seated intrusion-related-vein genesis.

Pogo is an underground mine that uses spiral ramps and declines to access the ore and cut-and-fill drift mining methods. A covered conveyor system feeds ore from the mine to the conventional SAG (semi-autogenous grinding) and ball mill grinding circuit, gravity circuit, and then to flotation and CIP (carbon-in-pulp) cyanidation processes. The mill treats 2,500 tons per day. After cyanide detoxification, the tailings are filtered and then either drystacked or used as paste backfill in the mine workings.

SMM Pogo invested \$50.0 million into development during 2014 with major projects focused on accommodating the enlarged resource base and initiating mining of the East Deep zone. One of the major projects in the mine was driving a 14 -foot-diameter ventilation raise from 1170 ramp to the surface near the 2150 portal (photo 16). In the mill, Pogo is adding a second CIP tank that they plan to commission in early 2015. Construction continued on the new number 3 water treatment plant, which is expected to be in service by late summer 2015 . The new plant will allow Pogo to maintain discharged water within quality standards.

Pogo's mill processed 967,230 tons of ore and recovered 342,147 ounces of gold in 2014 (table 22), slightly more than in 2013. Mine production was also marginally more than in 2013 , with all ore coming from the East Deep zone in the latter half of

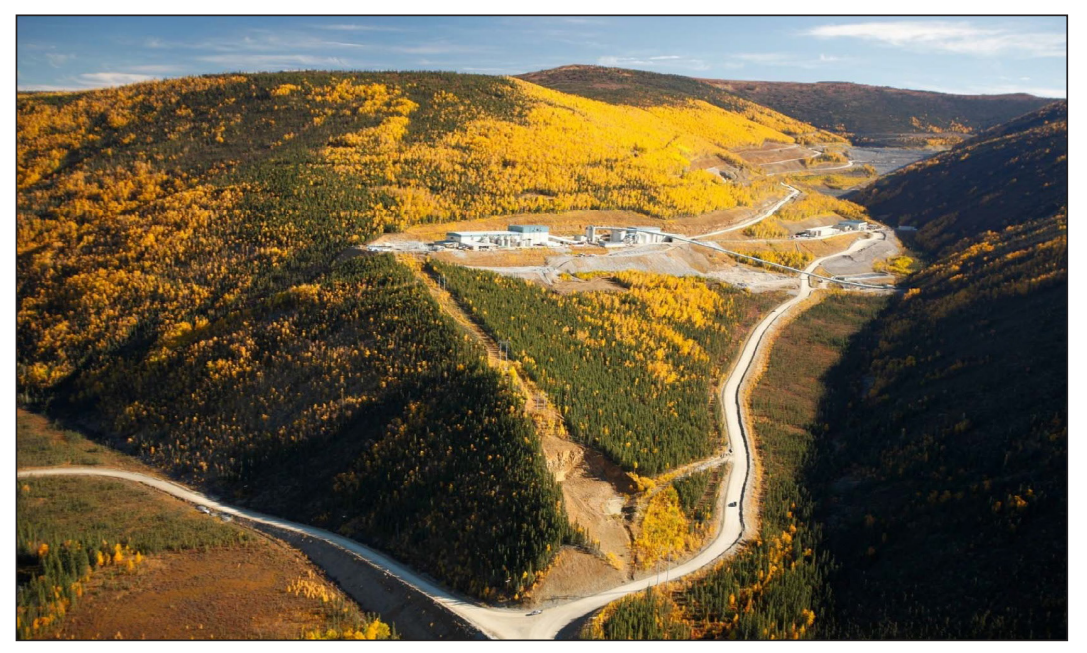

Photo 15. Pogo Mine, northeast of Delta Junction in east-central Alaska. Operated by Sumitomo Metal Mining Pogo LLC, Pogo is an underground quartz-veinhosted gold mine that produced 342,147 ounces of gold in 2014, and is poised to achieve the 3-million-ounce total production level by third quarter 2015. Photo from Pogo Mine annual presentation to the Alaska Large Mine Permitting Team posted on State of Alaska, Department of Natural Resources, Large Mine Permitting website.

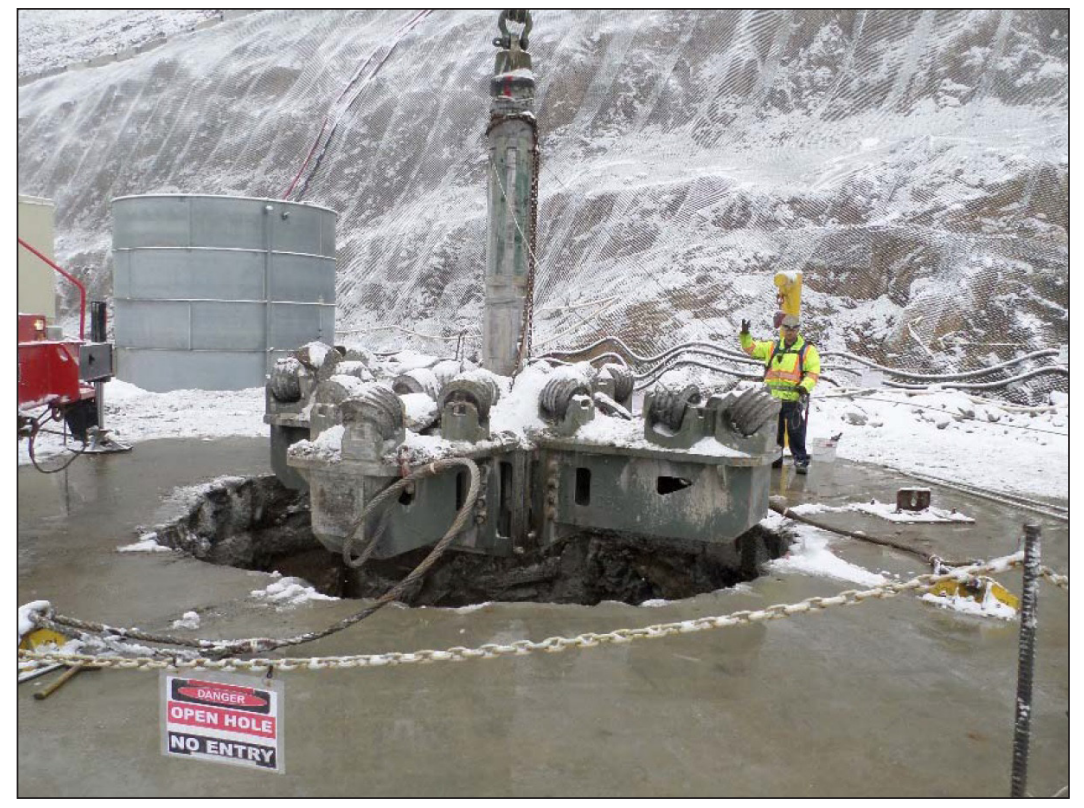

Photo 16. Raise boring machine completing a 14-foot-diameter ventilation raise at Pogo Mine. The ventilation raise was completed in 2014 to provide ventilation for full-scale production from the East-Deep zone, a recently delineated ore zone that is a fault offset of the original Liese zone. Photo from Pogo Mine's annual presentation to the Alaska Large Mine Permitting Team, posted on State of Alaska, Department of Natural Resources, Large Mine Permitting website. 
the year. The ore grades in the East Deep matched or exceeded expectations, but unanticipated faults and fractures required additional ground control. During record summer rainfall in 2014 Pogo allowed the lower part of the Liese zone mine workings to flood, storing 38 million gallons, and avoiding discharge of excess water. Sumitomo Metal Mining Co. Ltd. expects an approximate 2 percent increase in gold production from Pogo in 2015. A milestone of the 3 millionth ounce of production is expected in the third quarter of 2015. Sumitomo reports reserves and resources of approximately 4.5 million ounces of gold as of the end of December 2014.

Pogo reported having 314 full-time-equivalent employees and 100 seasonal contractors on site in 2014 . The mine exceeded 1 million work hours and completed the year with no lost-time incidents. The Pogo mine achieved ISO 14001 Certification for environmental stewardship, health, and safety in 2014 and is committed to maintain that certification.

\section{Usibelli Coal Mine}

Usibelli Coal Mine Inc. is a local, family-owned coal mining company in production since 1943 . The company mines coal from leases on State-owned lands in the Healy area. The main leases are in the Hoseanna Creek and Jumbo Dome areas. The coal is hosted in the Suntrana Formation, a Miocene-age sequence of interbedded non-marine sandstones, pebbly sandstone, siltstone, clay, and coal. There are four active and past resources: Poker Flats produced about 27 million tons of coal since the 1970s and the site is now in full reclamation; Gold Run Pass, which is near the end of the reclamation process; Two Bull Ridge, which has 15 million tons of reserve with 3.5-8 cubic yards of overburden for each ton of coal, and multiple seams with the number 4 seam up to 32 feet thick; and Jumbo Dome with 83 million tons, and the number 4 seam 40 feet thick. All coal is subbituminous, low-sulfur coal.

Usibelli produced coal from its Two Bull Ridge and Jumbo Dome sites near Healy, with an output of 1.5 million tons in

\begin{tabular}{|c|c|c|c|c|c|c|}
\hline \multicolumn{7}{|c|}{ Table 22. Pogo Mine production statistics, 2006-2014. } \\
\hline & $\begin{array}{l}\text { Tons Ore } \\
\text { Mined }\end{array}$ & $\begin{array}{l}\text { Tons Ore } \\
\text { Milled }\end{array}$ & $\begin{array}{c}\text { Ounces of } \\
\text { Gold Recovered }\end{array}$ & $\begin{array}{c}\text { Recovery } \\
\text { (\%) }\end{array}$ & $\begin{array}{l}\text { Head Grade } \\
\text { Gold (oz/ton) }\end{array}$ & Employees $^{\mathrm{a}}$ \\
\hline 2006 & 447,129 & 338,000 & 113,364 & 85.0 & 0.395 & 477 \\
\hline 2007 & 715,665 & 715,400 & 259,820 & 84.4 & 0.430 & 339 \\
\hline 2008 & 882,400 & 818,237 & 347,219 & 83.8 & 0.506 & 285 \\
\hline 2009 & 944,823 & 930,836 & 389,808 & 88.2 & 0.475 & 272 \\
\hline 2010 & 900,585 & 947,189 & 383,434 & 89.6 & 0.452 & 300 \\
\hline 2011 & 892,725 & 929,020 & 325,708 & 89.6 & 0.392 & 310 \\
\hline 2012 & 815,922 & 875,351 & 315,886 & 89.7 & 0.402 & 335 \\
\hline $2013^{b}$ & 963,229 & 875,351 & 337,393 & 90.2 & 0.395 & 320 \\
\hline 2014 & 972,406 & 967,230 & 342,147 & 89.0 & 0.396 & 320 \\
\hline Total & $7,534,884$ & $7,396,614$ & $2,814,779$ & -- & -- & -- \\
\hline
\end{tabular}

2014, down from 1.6 million tons in 2013 (fig. 20). The majority of the coal is used for in-state electrical power generation, while 513,000 tons were exported through the coal export facility at Seward. The export facility is owned by the Alaska Railroad Corp. and operated by Aurora Energy Services LLC, a subsidiary of Usibelli. Usibelli has approximately 140 million tons of reserves on State leases. The Alaska Railroad shipped 1.267 tons of coal, comprising nearly 26 percent of all freight on the railroad in 2014. Golden Valley Electric Association, one of Usibelli's primary customers, is in the process of commissioning the Healy Number 2 power plant, a 50-megawatt coal-fired electrical plant at the mouth of the mine, which is expected to be on line by the end of 2015. The Healy Number 2 is projected to use about 300,000 tons of coal per year.

Usibelli reports 115 full-time-equivalent employees, all of whom are Alaska residents with an average of 12 years of service. Second, third, and fourth generation employees comprise 36 percent of the workforce.

\section{SOUTH-CENTRAL REGION}

Development expenditures totaled $\$ 747,590$ for 11 projects in the South-central region, 16 percent greater than in 2013. Additional development in this region was reported confidentially. The region supported an estimated 2 full-time-equivalent jobs devoted to development. Development expenditures were noted for placer, sand and gravel, and unclassified sector in the region in 2014.

The Chuitna Coal project is a major coal mining and export development project being designed and proposed by PacRim Coal LP as a surface coal mine with contemporaneous reclamation to recover an estimated 300 million tons of subbituminous ultra-low-sulfur coal. The resource is located in the Beluga Coal Field of South-central Alaska, approximately 45 miles west of Anchorage on the west side of Cook Inlet. The current project proposal consists of a surface coal mine and associated support facilities, mine access road, coal transport conveyor, personnel housing, air strip facility, a logistics center, and coal export terminal. The current project predicts a minimum 25 -year mine life with an annual production rate of up to 12 million tons. PacRim started the process to update permits in 2006; as of the end of 2014 they had not yet submitted a completed permit application package for the Chuitna Coal project. PacRim provided no information on expenditures or employment for 2014. 
The 2014 reported value of production in the South-central region is estimated to be $\$ 7.32$ million, 44 percent lower than in 2013. Estimated employment by the 29 producing operators is estimated at 40 full-time-equivalent positions. Placer gold production of 1,535 ounces (a 36 percent decrease from 2013) was reported by 18 operators in the South-central region in 2014; all operations were reported to be small, with only 12 full-timeequivalent jobs. The South-central region's total reported rock, sand, and gravel production was 161,062 tons, reported by six producers, with an estimated 9 full-time-equivalent employees. The small number of operators (six reported in 2014, compared to 31 operators in 2013) indicates that the 82 percent decline in sand and gravel production from 2013 represents a significant reporting shortfall rather than a real drop in production. Rock production from the South-central and Alaska Peninsula regions, combined for confidentiality reasons, totaled more than 1 million tons of rock by five operations and an estimated 57 full-time-equivalent employees (a production increase of almost 2,000 percent from 2013). Peat production was reported in 2011 and 2012, but not in 2013 and 2014.

\section{SOUTHWESTERN REGION}

The Donlin Gold project (photo 17), located 270 miles west of Anchorage and 10 miles north of the village of Crooked Creek, is the major development project in the state and is currently in the Preliminary Draft EIS process. The project is operated by Donlin Gold LLC, equally owned and supported by NovaGold Resources and Barrick Gold Corp. Donlin Gold has an exploration and mining mineral lease agreement with Calista Corp., the ANCSA regional corporation, and renewed their cooperation with a surface-use agreement with The Kuskokwim Corp., which comprises ten villages on the middle Kuskokwim River.

Placer gold was discovered in the area in 1909 and placer mining continues nearby. Modern lode exploration began in 1974 and surface exploration continued until 1988. In 1988 and 1989 Western Gold Exploration and Mining Co. had an active surface and drilling exploration program and completed an initial resource estimate of 3 million tons containing 218,908 ounces of gold. Intensive drilling began with Placer Dome U.S. Inc. in 1995; NovaGold took over active exploration as the operating joint-venture partner in 2001. Barrick Gold took over Placer Dome's interest in 2006 and the partnership completed an updated resource estimate in early 2008 that resulted in a measured and indicated resource of 401 million tons at 0.072 ounce of gold per ton containing 29.4 million ounces within total identified resources of 460 million tons at 0.071 ounce of gold per ton, containing 33.7 million ounces of gold; based on those resources the partnership launched an initial feasibility study in 2008. In 2010 the current partnership between NovAGoLD and Barrick Gold formed Donlin Gold LLC, which completed the most recent feasibility study in 2011. In 2012, as the lead agency, Donlin launched the environmental impact statement (EIS) process with the U.S. Army Corps of Engineers.

The Donlin deposit is hosted in and around a Late Cretaceous rhyodacite dike swarm that intrudes graywacke and shale of the Cretaceous Kuskokwim Group. Mineralization in the main ACMA-Lewis resource consists of quartz, quartz-carbonate, and sulfide (pyrite-arsenopyrite) veins. Gold is tightly bound in the lattice of arsenopyrite. Donlin is classified as a low-sulfidation epithermal deposit. The current total identified resource is 698 million tons at 0.61 ounce per ton gold containing 45 million ounces of gold (appendix F).

The planned project, based on a proven and probable reserve of 556 million tons containing 33.9 million ounces of gold (appendix F), would have a mine life of 27.5 years. The projected annual production rate of 1.1 million ounces of gold would more than double Alaska's current gold output. The open-pit mine would move 420,000 tons of material per day, and the mill would process 59,000 tons per day through flotation, pressure oxidation, and CIP leach facilities. The project would include the mine, mill, tailings facility, 600-person camp, airport, road to a river port on the Kuskokwim River, and a saltwater port at Bethel. The mine and mill would require a 150-megawatt power

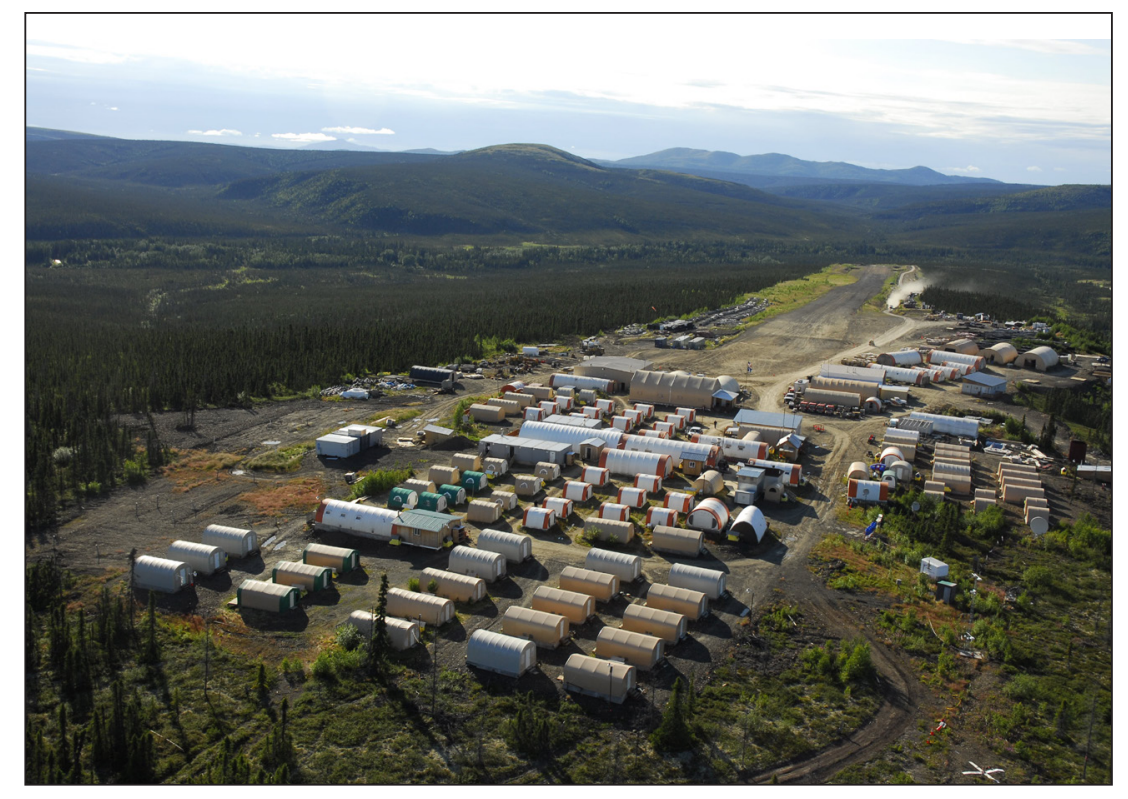

Photo 17. Exploration camp and airstrip at the Donlin Gold project site. Donlin Gold partners NOVAGolD and Barrick Resources are progressing through the permitting process on the proposed mine, which would produce more than 33 million ounces of gold under a lease agreement with Calista Corp. Photo provided by Donlin Gold LLC. 
plant. The plan also includes a 14-inch, 339-mile-long natural gas pipeline from Cook Inlet.

During 2014 Donlin Gold continued public engagement and work on the permitting process. Public engagement included working with local communities to provide information on the project, and supporting community events, workforce development, and education. Donlin invested in the National Fish and Wildlife Foundation's Alaska Fish and Wildlife Fund conservation initiative designed to protect, conserve, and restore fish and wildlife in Alaska. Donlin continued to provide information to the Corps of Engineers and other agencies involved in the EIS process and submitted an application for a natural gas pipeline right-of-way to the Alaska State Pipeline Coordinator's Office. These activities are carried out by an estimated 44 fulltime-equivalent staff, including 10 employees in a rotating crew at the project site and 34 staff in Bethel, Anchorage, and Aniak. NovaGold reported 2014 expenditures of $\$ 13.7$ million toward its share of the joint venture. Donlin expects the Preliminary EIS to be released in 2015 .

The 2014 value of production in the Southwestern region is estimated to be $\$ 2.65$ million, slightly more than in 2013 . The production total includes reported recovery of 1,350 ounces of gold and 547 ounces of silver by WestMountain Gold Inc. from their bulk sampling program at the Terra exploration project. Placer gold production in the southwestern region is estimated at 308 ounces in 2014, only 20 percent of the 2013 estimate. Only five operators, half of 2013 , reported placer gold production, with an estimated full-time-equivalent employment of three positions.

A single sand and gravel operator reported production in 2014; for comparison, there was no reported production in 2013.

\section{SOUTHEASTERN REGION}

Development occurred at the two major hard-rock metals mines, placer mines, gravel pits, and rock quarries in the Southeastern region during 2014, with a reported value of $\$ 17.1$ million (table 11), 23 percent of the 2013 total. However, a significant amount of development expenditures from the Southeastern region were requested to remain undisclosed. We estimate development-related employment in the region to be equivalent to 106 full-time jobs.

The 2014 value of production in the Southeastern region is estimated to be $\$ 536.9$ million, a 5 percent decline from 2013 , with employment of 584 full-time-equivalent positions. A single placer gold operator and the two hard-rock mines reported gold production totaling 176,634 ounces, 3 percent more than 2013 , and the second most productive region after the Eastern Interior. Sand and gravel production of 169,304 tons, 56 percent of the 2013 volume, was reported by six operators with 10 full-time- equivalent employees. Rock production totaling 142,970 tons, nearly twice the 2013 volume, was reported by three operators with eight full-time-equivalent employees assigned to the effort.

\section{Greens Creek Mine}

Greens Creek Mine, one of the world's largest and lowestcost primary silver mines, is owned by Hecla Mining Co. through its wholly-owned subsidiary, Hecla Greens Creek Mining Co. (photo 18). The mine opened in 1989 and, except for an approximately 2-year hiatus, has been in continuous operation since. The mine is located in the Southeastern region, in the Tongass National Forest near Hawk Inlet on Admiralty Island, approximately 18 miles southwest of Juneau, on U.S. Forest Service and private patented land in the City and Borough of Juneau. The mine operates successfully in a unique setting, completely enclosed within Admiralty Island National Monument. Access to the mine is by sea, then a 13-mile access road. Facilities include the Greens Creek underground mine, surface mill, dry stack tailings facility, tailings storage

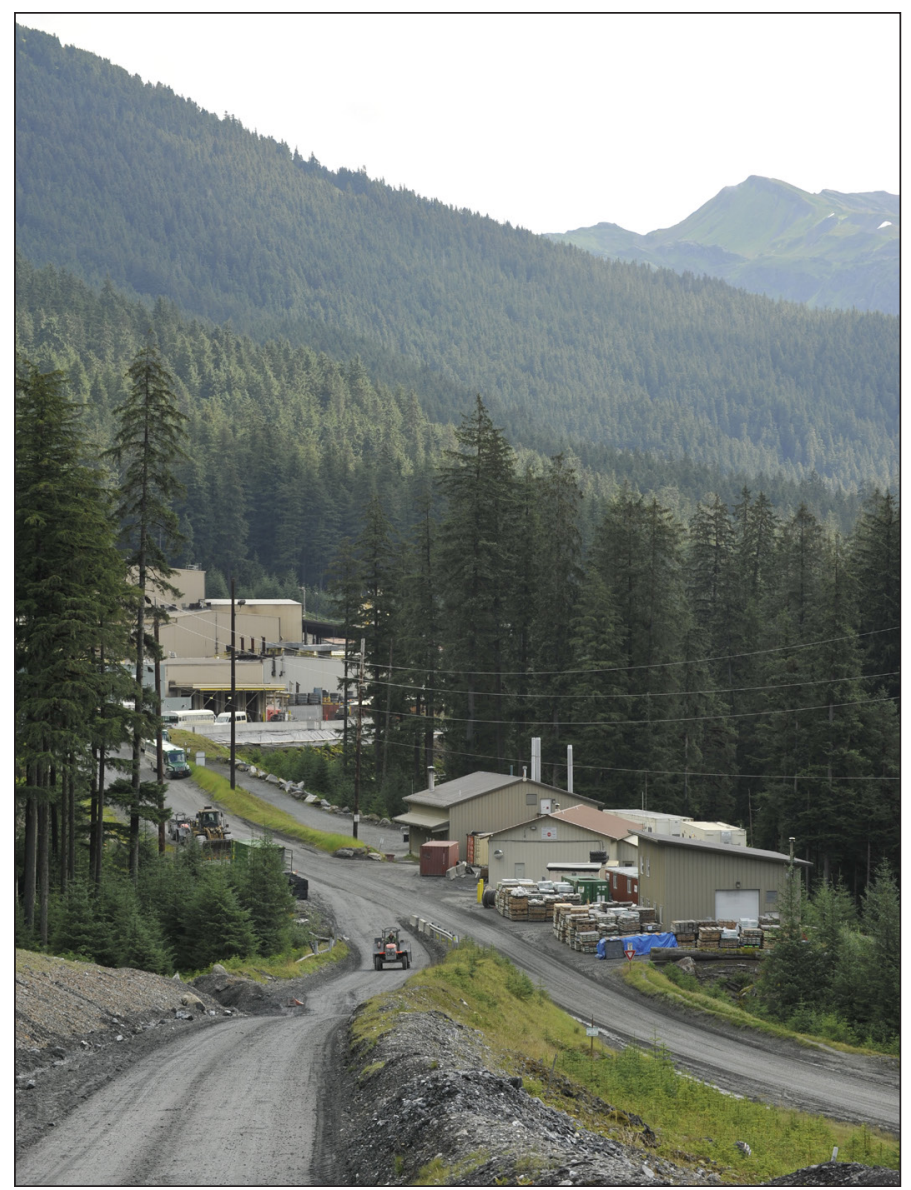

Photo 18. A portion of the Greens Creek surface and mill facilities on Admiralty Island, 18 miles southwest of Juneau. The silver-rich polymetallic massive-sulfide mine is operated by Hecla Greens Creek Mining Co. and produced 7.8 million ounces of silver along with byproduct lead, zinc, and gold, for a cash cost of $\$ 2.89$ per ounce of silver. Photo provided by Mike Satre, Hecla Greens Creek Mining Co. 
facility, water treatment system, wastewater treatment plant, administrative and camp facilities, ferry dock, and deep-water ship-loading facility. Most employees commute daily by ferry from Juneau. Power is supplied by hydroelectric infrastructure and diesel generators. Greens Creek produces a silver-gold doré and sulfide concentrates containing zinc, lead, silver, and gold, and ships the concentrate from a deep-water port.

The discovery of the Greens Creek deposit by the Pan Sound Joint Venture started with a 1973 regional geochemical reconnaissance program. The 1974 discovery of the Big Sore subcrop of actively oxidizing massive sulfide resulted from following up an anomalous zinc stream-sediment sample from a nearby stream. From the discovery hole in 1975 until initial production in 1989, nearly continuous exploration and predevelopment work coincided with the beginning of the modern environmental movement and a 1978 presidential proclamation and subsequent 1980 congressional passage of the Alaska National Interest Lands Conservation Act (ANILCA). ANILCA included designation of the Admiralty Island National Monument and a provision to allow validation of the original claims over a 5 -year period ${ }^{18}$. Numerous mining and natural resource companies in various joint-venture agreements were involved in the exploration and development of Greens Creek and the coincident ongoing battles over land and mineral tenure and operations permits. An initial geologic indicated resource of 2.1 million tons with a net smelter return value of $\$ 90$ per ton was recognized in 1977 by Noranda Mining Inc., and underground exploration began in 1978. An initial feasibility study completed by Noranda in 1983 identified proven and probable reserves of 2.84 million tons of 14.42 ounces of silver per ton, 0.093 ounce of gold per ton, 8.56 percent zinc, and 2.93 percent lead with an additional 1.45 million tons of geologic reserve $e^{18}$. At the time of first ore production in February 1989 the major partners were Hecla and Kennecott Minerals Co. under the name Kennecott Greens Creek Mining Co. The initial mine plan called for a 1,000-tons-per-day, 355-days-a-year operation with an 11-year mine life. The mine continued production until low metal prices forced closure in February 1993 (table 23) ${ }^{18}$. Aggressive and successful definition and exploration drilling continued during the initial mining and subsequent shutdown periods. By 1994 a new southwest ore body had a recoverable reserve of 2.4 million tons at 32.86 ounces of silver per ton, 0.244 ounce of gold per ton, 12.35 percent zinc, and 5.91 percent lead ${ }^{18}$; this reserve was the source of the ore when mining resumed in July 1996 at a rate of 1,320 tons per day (table 23).
In addition, the main reserve had been expanded to 11.0 million tons at 13.3 ounces of silver per ton, 0.12 ounce of gold per ton, 12.8 percent zinc, and 4.0 percent lead $^{19}$. In August 1996, the Land Exchange Bill was enacted, which allowed Greens Creek exploration and mineral rights to 7,301 acres comprising much of the original, pre-ANILCA, unpatented claims. Mining and exploration has been ongoing since 1996, with Hecla Mining Co. taking over full ownership in 2008.

The Greens Creek deposit is a polymetallic, stratiform, volcanogenic massive-sulfide deposit. The host rock consists of predominantly marine sedimentary, and Late Triassic mafic to ultramafic volcanic and plutonic rocks, which have been subjected to multiple periods of deformation. These deformational episodes have imposed intense tectonic fabrics on the rocks. Mineralization is present most often along the contact between a structural hanging wall of quartz-mica-carbonate phyllites and a structural footwall of graphitic and calcareous argillite.

The underground mine is accessed by a ramp from the surface and produces approximately 2,100-2,300 tons of ore per day. The primary mining methods are cut-and-fill and longhole stoping. The Greens Creek ore processing facility includes a SAG/ball mill grinding circuit to grind the run of mine ore to liberate the minerals and produce a slurry suitable for differential flotation of mineral concentrates. A gravity circuit recovers electrum, a gold-silver alloy in the ore. Doré and gravity concentrates are produced from this circuit prior to flotation. Three flotation concentrates are produced, including a silver-rich lead concentrate, a zinc concentrate, and a zinc-rich polymetallic bulk concentrate. Stopes are backfilled with a combination of mill waste (tailings) and cement. This backfilling process stabilizes the production voids and allows extraction of the ore beside, above, and even below the backfilled area. Greens Creek manages rock by sorting it by its acid-generating and acid-neutralizing potential. Half the tailings and the waste-rock with the greatest potential for acid generation are contained underground in the backfill for structural support. The remainder of waste rock and tailings goes into managed surface disposal facilities.

In 2013 Greens Creek received approval to expand the dry stack tailings facility. Geotechnical work and construction toward the expansion was initiated and continued through 2014. Total development expenditures are not publicly available and additional development was not specified, but it likely focused on underground mine development and rehabilitation, definition drilling, mining fleet replacement, and surface infrastructure improvements.

\footnotetext{
${ }^{18}$ West, A.W., 2010, The History of Greens Creek Exploration, in: Taylor, C.D., and Johnson, C.A., editors, 2010, Geology, geochemistry, and genesis of the Greens Creek massive sulfide deposit, Admiralty Island, southeastern Alaska: U.S. Geological Survey Professional Paper 1763,429 p., 7 plates on CD.

${ }^{19}$ Swainbank, R.C., Bundtzen, T.K., Clough, A.H., and Henning, M.W., 1997, Alaska's mineral industry 1996: Alaska Division of Geological \& Geophysical Surveys Special Report 51, 68 p. doi: $\underline{10.14509 / 2650}$
} 
Production at Greens Creek in 2014 exceeded the prior year's production by almost 400,000 ounces of silver, totaling 7.8 million ounces silver (table 23). Increased mill throughput, at an average of 2,236 tons per day, and higher ore grade contributed to the increased production. Total mill recovery was approximately 72 percent silver, 87 percent zinc, 77 percent lead, and 63 percent gold. Mining costs increased by 1 percent in 2014 as a result of higher labor costs, while milling costs per ton decreased by 10 percent in 2014 due to an increased availability of grid-based hydroelectric power. Hecla considers silver to be the primary product of Greens Creek and claims a cash cost of production, after byproduct credits, of $\$ 2.89$ per ounce of silver. Production in 2015 is expected to be 7.3 million ounces of silver.
As of December 31, 2014, Hecla reported proven and probable reserves of slightly less than 7.7 million tons of ore at 12.2 ounces of silver per ton, 0.100 ounce of gold per ton, 3.1 percent lead, and 8.3 percent zinc containing 94.0 million ounces of silver, sufficient for a remaining mine life at Greens Creek of 9 years. The total identified resource, inclusive of the proven and probable reserves, are 11.97 million tons at 12.5 ounces of silver per ton, 0.98 ounce of gold per ton, 3.0 percent lead, and 7.8 percent zinc containing nearly 150 million ounces of silver (appendix F).

Hecla reported 415 full-time-equivalent employees at Greens Creek for 2014, and does not differentiate between employees engaged in production and development.

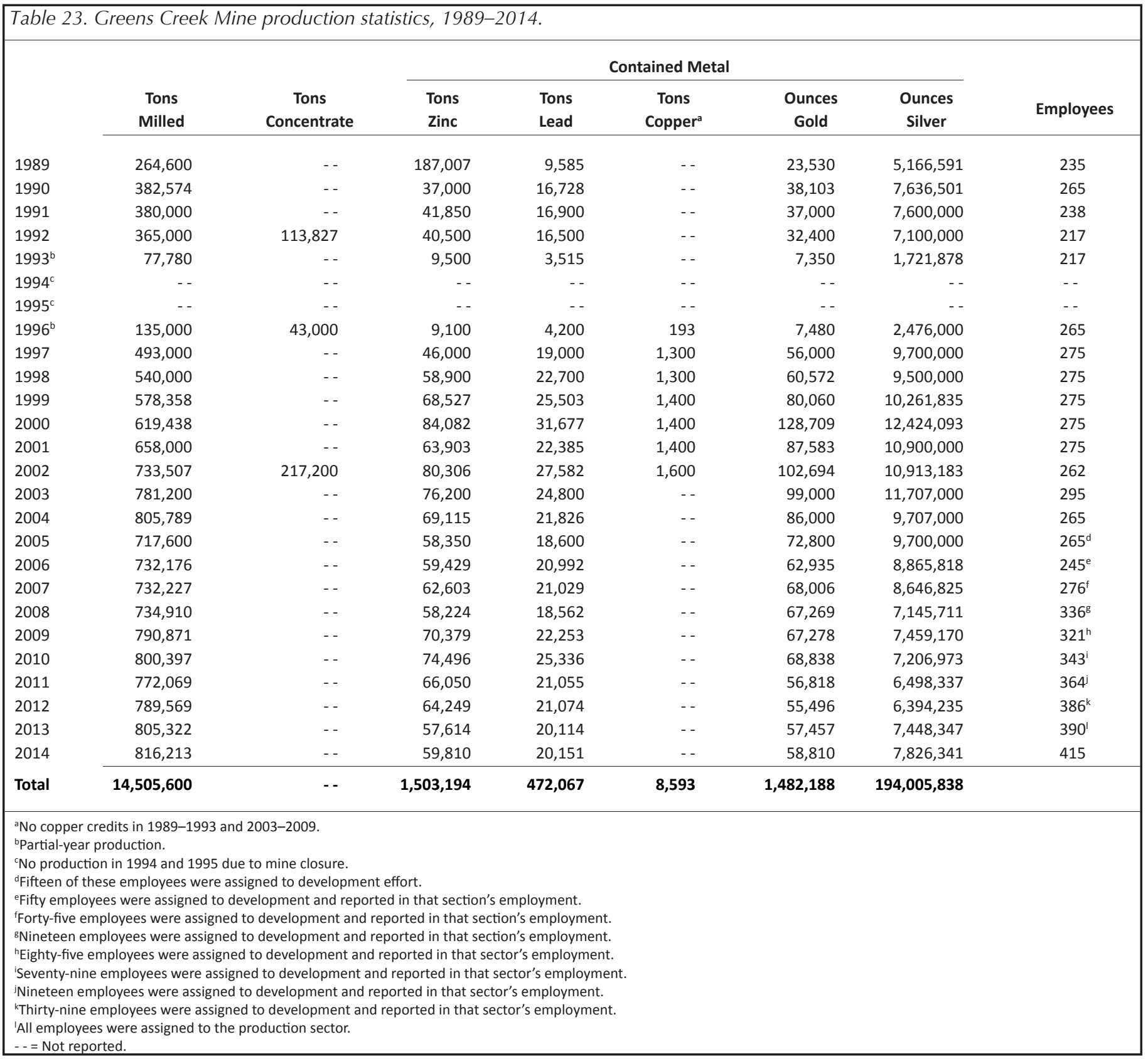




\section{Kensington Mine}

The Kensington underground gold mine and associated mill facilities are in the Berners Bay mining district on the east side of Lynn Canal, about 45 miles north-northwest of Juneau (photo 19). The project is owned and operated by Coeur Alaska Inc., a subsidiary of Coeur Mining Inc. Kensington is on private and U.S. Forest Service lands in the City and Borough of Juneau, and access to the mine is by air or sea. The major Kensington Mine facilities include the underground mine, underground paste backfill plant, surface mill, tailings treatment facility, administrative and camp facilities, generator facilities, water treatment facilities, and marine dock facility. Power is supplied by on-site diesel generators.

Coeur Alaska controls two contiguous land groups: the Kensington and Jualin properties. Each property consolidates several historical mines and prospects that comprise the northwestern extent of the Juneau gold belt. Gold-bearing veins were initially discovered in 1886 and started producing gold in 1887. Prior to World War II an estimated 65,000 ounces gold were produced from 137,000 tons of material, mostly from the Jualin and Comet mines. The modern exploration period started in 1980 when Homestake Mining Co. optioned the Kensington property; subsequent exploration was carried out by a succession of companies until Coeur took over both the Kensington and Jualin properties in 1995. Between 1995 and 2005 Coeur completed exploration, successfully permitted the mine and facilities, and began construction. The total identified resource in 2005 was 7.32 million tons at 0.26 ounce per ton containing 1.9 million ounces, including probable reserves of 4.21 million tons at 0.250 ounce per ton containing 1.05 million ounces. Construction was halted shortly after it began, when environmental groups filed suit challenging the Corps of Engineers permit for the tailings disposal facility in Lower Slate Lake. After successive decisions and appeals, the case was heard by the U.S. Supreme Court, which decided in favor of Coeur in 2009, allowing development and mining to proceed. Kensington mine began commercial production on July 3, 2010.

The Kensington ore deposit consists of multiple mesothermal quartz, carbonate, and pyrite vein swarms and discrete quartz-pyrite veins hosted in the Cretaceous-aged Jualin diorite. Structure in the area is dominated by the Gastineau shear zone to the southwest, and the Kensington shear zone, which passes through the mine area. The gold occurs as native grains in quartz veins and is associated with pyrite and various gold-telluride minerals (photo 20). Both shear-hosted and extensional quartz vein arrays are common at Kensington and form roughly north-south-trending zones that dip steeply east, although individual vein sets in the zones can dip at low angles, sub-parallel to the broader zones. The mineralization is approximately 55 million years old.
Kensington Gold Mine is accessed by a horizontal tunnel and utilizes conventional and mechanized underground mining methods. Mining is accomplished by underground long-hole stoping and drift-and-fill methods. Ore is processed in a flotation mill that produces a gold-bearing concentrate that is sold to third-party smelters. Waste material from the flotation process is deposited in an impoundment facility on the property or combined with cement and used as backfill in the mine.

Coeur reported development expenditures of $\$ 16.2$ million for 2014. Work included underground access and development drilling and surface road improvements including resurfacing and interim reclamation. The company reported underground production drilling of 88,295 feet.

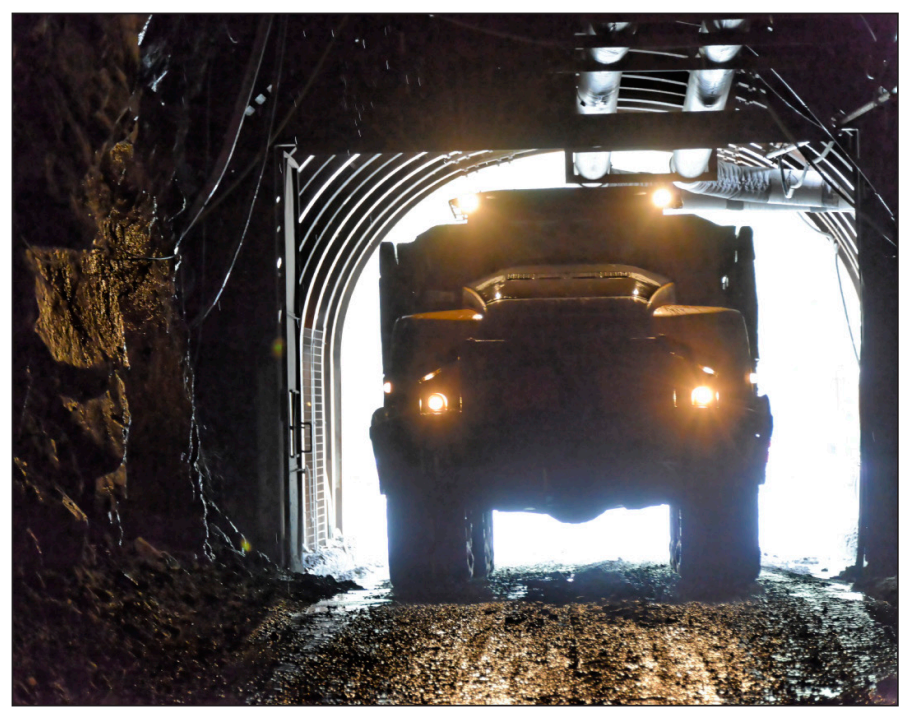

Photo 19. Haul truck entering Kensington Mine. Kensington is a quartz-vein-hosted gold deposit 45 miles northwest of Juneau operated by Coeur Alaska Inc. The mine had a record production of 117,823 ounces of gold in 2014. Photo provided by Coeur Alaska Inc.

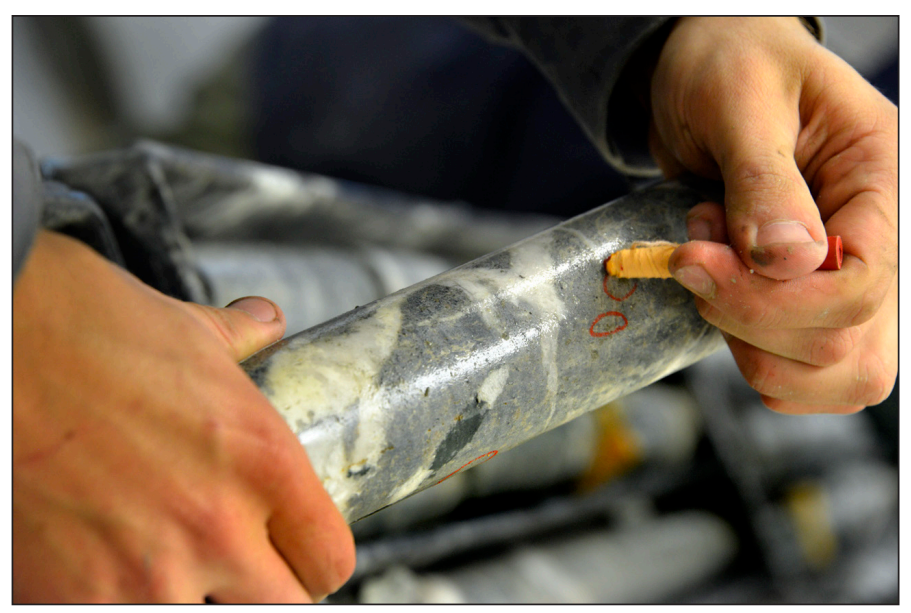

Photo 20. Coeur geologist marking visible gold in core. Gold in the veins at Kensington occurs as native grains, in pyrite, and in gold telluride minerals and is recovered in a flotation concentrate and shipped to an offsite smelter. Photo provided by Coeur Alaska Inc. 
Coeur's full-year production in 2014 was 117,823 ounces of gold, recovered from 635,960 tons milled (table 24) at a cost of $\$ 951$ per ounce. The gold output was the best year of production from the main deposit, an increase of 2.6 percent over 2013, and above Coeur's start-of-the-year estimate of 107,000-112,000 ounces. The operation finished the year with a record quarterly mill throughput of 167,417 tons (1,820 tons per day). Strong throughput, combined with robust grade and recovery performance, caused costs to decline 10 percent to $\$ 845$ per ounce in the fourth quarter. Kensington shipped approximately 18,378 tons of concentrate containing approximately 120,469 ounces of gold to an offsite refinery. Coeur reported 322 full-timeequivalent employees at Kensington as of the end of 2014. The

\begin{tabular}{|c|c|c|c|c|}
\hline & $\begin{array}{c}\text { Ore } \\
\text { (tons milled) }\end{array}$ & $\begin{array}{l}\text { Ore grade gold } \\
\text { (ounce/ton) }\end{array}$ & $\begin{array}{c}\text { Gold Recovery } \\
\text { (\%) }\end{array}$ & $\begin{array}{l}\text { Gold produced } \\
\text { (ounces) }\end{array}$ \\
\hline $2010^{a}$ & 174,028 & 0.28 & 89.9 & 43,143 \\
\hline 2011 & 415,340 & 0.23 & 92.7 & 88,420 \\
\hline 2012 & 394,780 & 0.22 & 95.6 & 82,125 \\
\hline 2013 & 553,717 & 0.21 & 96.6 & 114,821 \\
\hline 2014 & 635,960 & 0.20 & 94.1 & 117,823 \\
\hline Total & $2,173,825$ & 0.22 & & 446,332 \\
\hline
\end{tabular}

company advised shareholders to expect gold production from Kensington to be 110,000-115,000 ounces in 2015.

An aggressive and successful drilling campaign to define a higher-grade resource was conducted in 2014 (see Exploration section). The work resulted in reserves of 690,00 tons at 0.185 ounce per ton at Kensington and Raven deposits within a total identified resource of 6.59 million tons at an average grade of 0.240 ounce of gold per ton ( 1.58 million total ounces) as of the end of 2014 (appendix F) from the combined Kensington, Raven, and Jualin deposits. The Jualin inferred resource of 289,000 tons at 0.619 ounce per ton gold is much higher than the average grade at Kensington and Raven. Permitting is underway for underground development at Jualin to provide access to underground drill stations; drilling at Jualin is expected to continue in 2015 and 2016 and initial production expected in 2017. Coeur plans to release a rescoped mine plan reflecting higher-grade, higher-margin production over an extended mine life at Kensington as well.

\section{ALASKA PENINSULA REGION}

A single rock quarry in the Alaska Peninsula region reported development and production in 2014; details were requested to remain confidential. There was no reported placer development or production.

\section{RECREATIONAL MINING}

Interest in recreational mining dropped significantly in 2014, largely due to depressed gold prices. Production attributed to recreational mining in 2014 was 56 ounces, compared with 884 ounces in 2013. Employment also fell significantly, from 48 fulltime-equivalent positions to 7 positions, down 85 percent. These data are based on time worked by 32 operators as reported in Applications for Permits to Mine in Alaska (APMAs) for suction dredges with 6 inch or smaller nozzles and recreational mining reported in voluntary questionnaires. Duration of employment was preferentially captured from Affidavits of Annual Labor, rather than APMAs, which may account for a portion of the lower 2014 employment value. The data suffer from reporting shortfalls, are minimum values, and do not take into account other types of recreational mining activities.

\section{DRILLING}

Twelve companies publicly reported a significant drilling program in Alaska in 2014 (table 25). Total drilling by 35 operators across all sectors and regions in 2014 was 504,069 feet (table 26), down 48 percent from almost 1 million feet of drilling in 2013 (table 27). The Southeastern region saw the largest amount of drilling in 2014 (fig. 22). Exploration drilling totaled 264,487 feet, development drilling totaled 173,496 feet, and production drilling totaled 66,086 feet (photo 21). Development and production drilling, especially at Alaska's large lode mines, is likely underreported. Blast-hole drilling during production at Alaska's large lode mines is not tracked. As an indicator of the health of the mineral industry across the full range of exploration projects to production, drilling in 2014 appears more in line with industry activity 10 years ago, before the dramatic rise in metal prices that began in about 2005 (table 27).

\begin{tabular}{|ll}
\hline Table 25. Companies publicly reporting significant drilling programs in Alaska, 2014. \\
\hline Coeur Alaska Inc. & Kinross Gold Corp. (Fairbanks Gold Mining Inc.) \\
Constantine Metal Resources Ltd. & Kiska Metals Corp. \\
Graphite One Resources Inc. & Pathfinder Mineral Services LLC \\
Hecla Greens Creek Mining Co. & Pebble Limited Partnership
\end{tabular}

Pure Nickel Inc. Sumitomo Metal Mining Pogo LLC Teck Alaska Inc. Ucore Rare Metals Inc. 


\begin{tabular}{|c|c|c|c|c|c|c|c|c|}
\hline \multicolumn{9}{|c|}{ Table 26. Drilling footage by region in Alaska, 2014. ${ }^{a}$} \\
\hline Type of drilling & Northern & Western & $\begin{array}{l}\text { Eastern } \\
\text { Interior }\end{array}$ & $\begin{array}{l}\text { South- } \\
\text { central }\end{array}$ & $\begin{array}{l}\text { South- } \\
\text { western }\end{array}$ & $\begin{array}{l}\text { South- } \\
\text { eastern }\end{array}$ & $\begin{array}{l}\text { Alaska } \\
\text { Peninsula }\end{array}$ & Total \\
\hline Coal subtotal & -- & -- & W & -- & -- & -- & -- & W \\
\hline Placer subtotal & 720 & 60 & 5,247 & 1,200 & -- & -- & -- & 7,227 \\
\hline Hardrock core ${ }^{b}$ & 75,111 & 7,686 & 27,867 & 2,904 & 6,280 & 367,258 & - & 487,106 \\
\hline Hardrock rotary & -- & -- & 9,736 & -- & -- & - - & - & 9,736 \\
\hline Hardrock subtotal & 75,111 & 7,686 & 37,603 & 2,904 & 6,280 & 367,258 & -- & 496,842 \\
\hline TOTAL (feet) & 75,831 & 7,746 & 42,850 & 4,104 & 6,280 & 367,258 & - & 504,069 \\
\hline \multicolumn{9}{|c|}{$\begin{array}{l}--=\text { Not reported. } \\
\text { aDrill footages do not include sand and gravel (industrial materials) drilling. } \\
\text { bHardrock drill footages undifferentiated by type (core or rotary) were included in the Hardrock core total. } \\
\text { W = Figures witheld for confidentiality purposes; included in hardrock rotary. }\end{array}$} \\
\hline
\end{tabular}

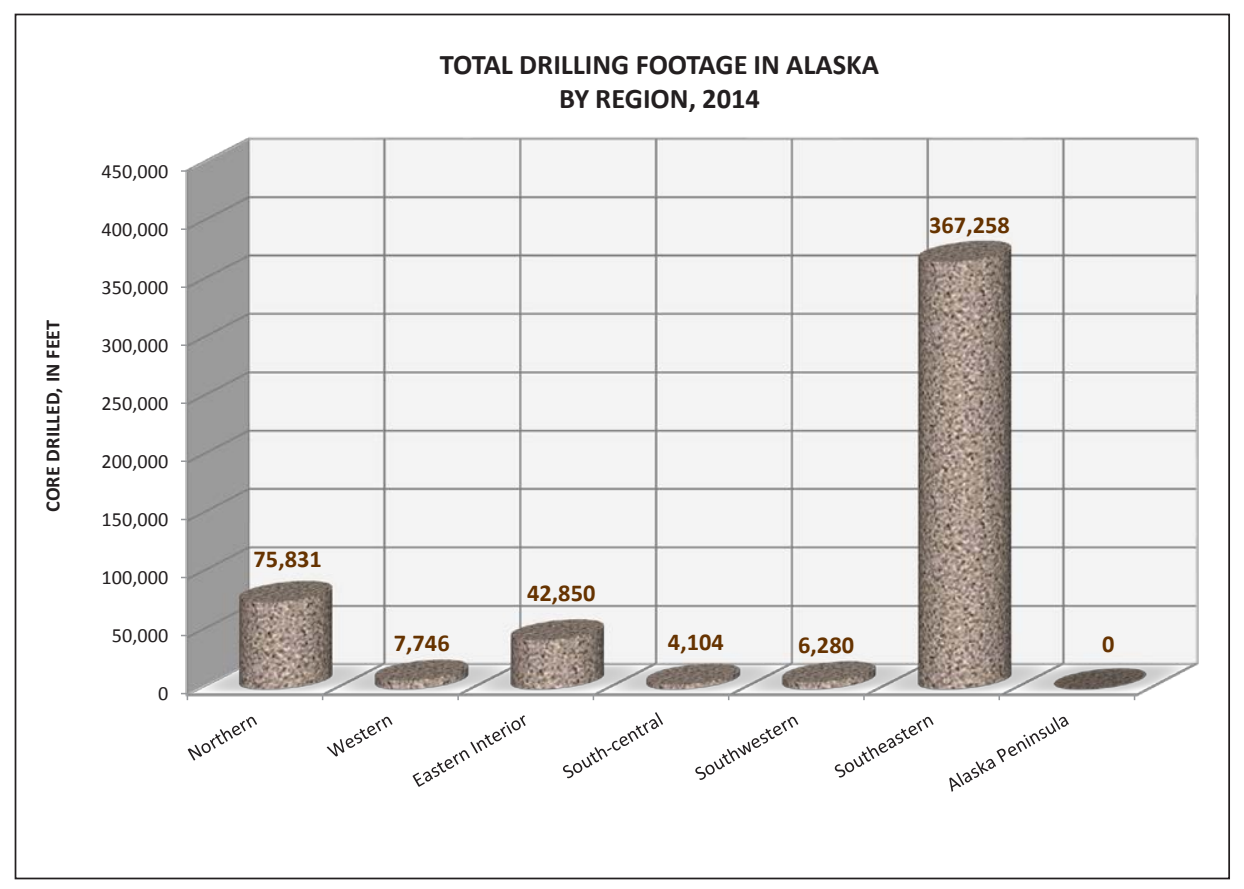

Figure 22. Total feet of core drilled in Alaska in 2014, by region.

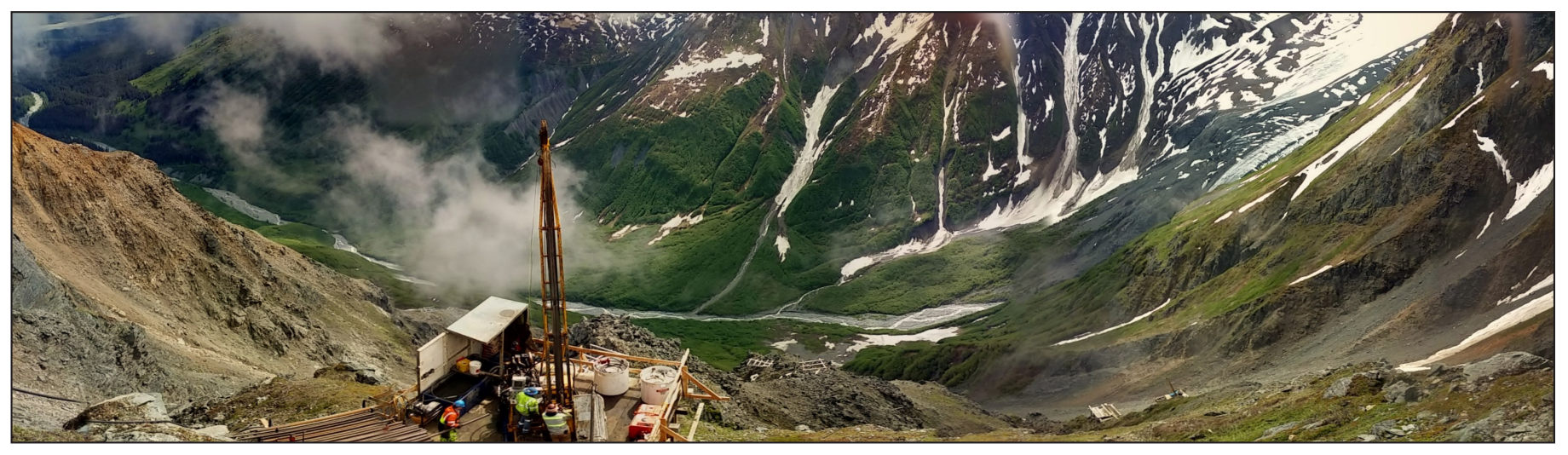

Photo 21. Diamond drill at the Palmer Project, northeast of Haines. Constantine Metal Resources had one of the larger exploration drill programs in the state during 2014; projects in southeastern Alaska were responsible for more drilling footage than any other region in the state. Photo provided by Constantine Metal Resources Ltd. 


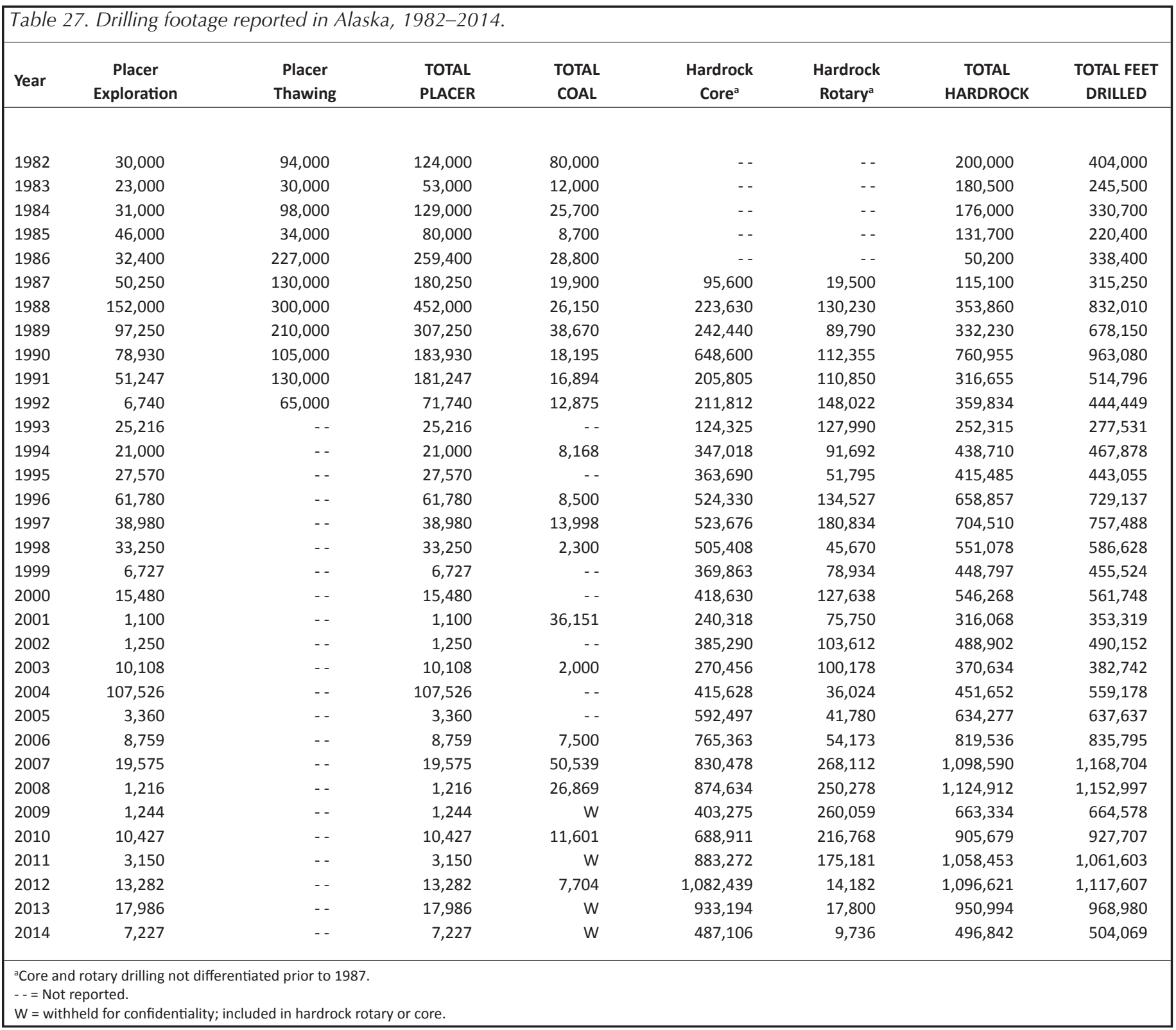




\section{ACKNOWLEDGMENTS}

The authors thank the companies, agencies, and individuals that responded to the questionnaires or phone calls and provided information about their activities and operations, including Alyeska Pipeline Service Co., Alaska Department of Transportation \& Public Facilities, Denali Borough, City and Borough of Juneau, Kenai Peninsula Borough, U.S. Forest Service, U.S. Bureau of Land Management, regional Native corporations, and the many large and small Alaska mining operations. Without their voluntary and timely information this report would not be possible. DGGS distributed hardcopy questionnaires with Division of Mining, Land \& Water's fall 2014 APMA mailing, Alaska’s Mineral Industry 2013 publication, and individually mailed 718 questionnaires in spring 2015, for a total of more than 1,188 questionnaires delivered. More than 117 responses were returned. Questionnaire requests were followed by phone calls and other means of contact. In addition to operational information, members of the public provided photos and images used in this report. These contributions are greatly appreciated. Where appropriate, these contributors have been acknowledged in the text.

The production of this publication depends upon the collaboration of several agencies. Listed here are staff from the major agency contributors who provided mining-related information. Conor Bell (Department of Labor and Workforce Development) provided updated mining employment and wage information. William Bishop (Alaska Department of Revenue) and Richard Lessard and Russell Kirkham (Department of Natural Resources/Division of Mining, Land \& Water [DNR/ DMLW]) provided government revenue data. William Groom, Charlene Bringhurst, and Chollada Jarupakorn (DMLW) and Jeff Jasper, Belinda Jerger, and Patty Robinson (Department of Natural Resources/Information Resource Management) provided information to track mineral activity, permits, and claims.

Larry Freeman (DGGS), Jennifer Athey (DGGS), Shane Lasley (Data Mine North), and Eric Van Oss (Department of Commerce, Community, and Economic Development/ Division of Economic Development) compiled the data and prepared the body of the text, tables, and appendices. The booklet's design, layout, and cover are by Joni Robinson (DGGS); graphic illustrations were created and updated by Jennifer Athey (DGGS); and Paula Davis (DGGS) updated the graphs and charts and edited the final version. DGGS provided funds for printing. 
APPENDIX A

U.S. Customary Units/Metric Units Conversion Chart

To convert from:

To:

Multiply by:

\begin{tabular}{|c|c|c|}
\hline \multicolumn{3}{|c|}{ Weight/Mass/Ore Content } \\
\hline ounces (avoirdupois) & grams & 28.350 \\
\hline ounces (troy) & grams & 31.1035 \\
\hline pounds & kilograms & 0.4536 \\
\hline short tons & metric tons & 0.9072 \\
\hline grams & ounces (avoirdupois) & 0.03527 \\
\hline & ounces (troy) & 0.03215 \\
\hline kilograms & pounds & 2.2046 \\
\hline metric tons & short tons & 1.1023 \\
\hline parts per million (ppm) & parts per billion (ppb) & 1,000 \\
\hline parts per million (ppm) & ounces per ton & 0.0292 \\
\hline parts per million (ppm) & grams/metric tons (tonnes) & 1.00 \\
\hline \multicolumn{3}{|c|}{ Length } \\
\hline miles & kilometers & 1.6093 \\
\hline yards & meters & 0.9144 \\
\hline \multirow[t]{3}{*}{ feet } & meters & 0.3048 \\
\hline & centimeters & 30.48 \\
\hline & millimeters & 304.80 \\
\hline \multirow[t]{2}{*}{ inches } & centimeters & 2.54 \\
\hline & millimeters & 25.4 \\
\hline kilometers & miles & 0.6214 \\
\hline \multirow[t]{2}{*}{ meters } & yards & 1.0936 \\
\hline & feet & 3.2808 \\
\hline \multirow[t]{2}{*}{ millimeters } & feet & 0.00328 \\
\hline & inches & 0.03937 \\
\hline centimeters & inches & 0.3937 \\
\hline \multicolumn{3}{|c|}{ Area } \\
\hline square miles & square kilometers & 2.590 \\
\hline \multirow[t]{2}{*}{ acres } & square meters & $4,046.873$ \\
\hline & hectares & 0.4047 \\
\hline square yards & square meters & 0.8361 \\
\hline square feet & square meters & 0.0929 \\
\hline \multirow{2}{*}{ square inches } & square centimeters & 6.4516 \\
\hline & square millimeters & 645.16 \\
\hline square kilometers & square miles & 0.3861 \\
\hline square meters & acres & \\
\hline \multicolumn{3}{|l|}{0.000247} \\
\hline & square feet & 10.764 \\
\hline & square yards & 1.196 \\
\hline \multirow[t]{2}{*}{ hectares } & acres & 2.471 \\
\hline & square meters & $10,000.00$ \\
\hline square centimeters & square inches & 0.155 \\
\hline square millimeters & square inches & 0.00155 \\
\hline \multicolumn{3}{|c|}{ Volume } \\
\hline cubic yards & cubic meters & 0.7646 \\
\hline cubic feet & cubic meters & 0.02832 \\
\hline cubic inches & cubic centimeter & 16.3871 \\
\hline \multirow[t]{2}{*}{ cubic meters } & cubic yards & 1.3079 \\
\hline & cubic feet & 35.3145 \\
\hline cubic centimeters & cubic inches & 0.06102 \\
\hline gallons (U.S.) & liters & 3.7854 \\
\hline liters & gallons (U.S.) & 0.2642 \\
\hline milliliters & ounces (fluid) & 0.03381 \\
\hline ounces (fluid) & milliliters & 29.5735 \\
\hline
\end{tabular}

SOURCE: Minerals Today, February 1993, U.S. Bureau of Mines.

Temperature conversions:

From degrees Fahrenheit to degrees Celsius, subtract 32 and multiply by 5/9.

From degrees Celsius to degrees Fahrenheit, multiply by $9 / 5$ and add 32 . 


\section{Appendix B}

\section{Companies and individuals reported to be producing metal in Alaska, 2014}

\section{Owner/Operator/Lessee}

David Jacobs

Jim Roland

Kib Cannon

Cannon Resources LLC

Timothy Williams

Bruce Hamma

Barbara Osborne

David Howland

Anita Tomsha

Bill Beistline

Christine Smith

Alaska Construction

Dean Willis

Don Glassburn

Fred Wilkinson

Gordon Fulton

Jack Hendrickson III

Shorti Jack Mining

James Bailey and family

James Stepp

John Lines

Karl Hanneman

Development

Keith Wright

Marc Stringfellow

Matthew Glover

Mike Johnson

Paul and Joni Manuel

Ray Lester

Lester Mines

Robert Hare

Rodney James

Rodney Mitchell

M\&M Mining

Roy Frazier

Ryan Smith

Alaska Construction

Scott Chaimberlain

Scott Thomas

Steve Olson

Olson Placers

Viktor Kravets

Walter Stockwell

Donald Smithwick

Fairbanks Gold Mining Inc.

Alan Las

Richardson Shield LLC

Andy Miscovich

Charley Walton

Daniel May

Polar Mining Inc.

George Seuffert, Jr.

Seuffert Mining Co.

Jeffrey Keener

Alder Creek Mines

Jerry Hassel

John Andresen

AM Mining

Keith Clark

Raymond Meder

Rob Robinson Jr

Sam and Donna Skidmore

\section{Region}

Eastern Interior

Eastern Interior

Eastern Interio

Eastern Interior

Eastern Interior

Eastern Interior

Eastern Interior

Eastern Interior

Eastern Interior

Eastern Interior

Eastern Interior

Eastern Interior

Eastern Interior

Eastern Interio

Eastern Interior

Eastern Interior

Eastern Interior

Eastern Interior

Eastern Interior

Eastern Interior

Eastern Interior

Eastern Interior

Eastern Interior

Eastern Interior

Eastern Interior

Eastern Interior

Eastern Interior

Eastern Interior

Eastern Interior

Eastern Interior

Eastern Interior

Eastern Interior

Eastern Interior

Eastern Interior

Eastern Interior

Eastern Interior

Eastern Interior

Eastern Interior

Eastern Interior

Eastern Interior

Eastern Interior

Eastern Interior

Eastern Interior

Eastern Interior

Eastern Interior

Eastern Interior

Eastern Interior

Eastern Interior

Eastern Interior
Creek, River, or Mine

District

Bonnifield

Bonnifield

Bonnifield

Bonnifield

Bonnifield

Chistochina

Chistochina

Circle

Circle

Circle

Circle

Circle

Circle

Circle

Circle

Circle

Circle

Circle

Circle

Deadwood Creek

Bender Pup, Deadwood Creek

Deadwood Creek

Crooked Creek

Gold Dust Creek

Mammoth Creek

Birch Creek

Gold Dust Creek

Switch Creek

Bottom Dollar Creek

Bottom Dollar Creek

Medicine Lake

Porcupine Creek, Deadwood Creek

Deadwood Creek

Ketchem Creek

Sourdough Creek

Banner Creek

Crooked Creek

Fort Knox mine

No Grub Creek, The Lost Mine Creek Fairbanks

Wolf Creek

Dome Creek

Goldstream Creek

Faith Creek

Lower Fairbanks Creek

Ready Bullion Creek

Dome Creek

Shamrock Creek

Flume Creek

Fox Creek

Vault Creek
Type of Operation

Open-pit placer

Open-pit placer

Open-pit placer

Open-pit placer

Recreational

Open-pit placer

Open-pit placer

Open-pit placer

Open-pit placer

Open-pit placer

Open-pit placer Open-pit placer

Open-pit placer

Open-pit placer

Open-pit placer

Open-pit placer

Open-pit placer

Open-pit placer

Open-pit placerAlaska Placer

Open-pit placer

Open-pit placer

Open-pit placer

Open-pit placer

Open-pit placer

Open-pit placer

Open-pit placer Open-pit placer

Open-pit placer

Open-pit placer

Open-pit placer

Open-pit placer

Open-pit placer

Open-pit placer

Open-pit placer

Open-pit placer

Open-pit placer

Open-pit hardrock

Open-pit placer

Open-pit placer

Open-pit placer

Open-pit placer

Open-pit placer

Open-pit placer

Open-pit placer

Open-pit placer

Open-pit placer

Open-pit placer

Open-pit placer

Open-pit placer 


\section{Operator}

Walter Largent

Voytilla Mining/Range Minerals

\section{A.J. Davis}

Bronk Jorgensen

45 Pup Gold Company LLC

Charles (Dick) and Robin L. Hammond

Chris Race

Goldnut's LLC

Cy Bras

Fedor Kuzmin

Harry Colburn

Mackinaw Productions

James Treesh

Jeffrey and Laura Thimsen

Judd Edgerton

Northway Mining \& Exploration

Pavel Legkun

Alaska Mining Expedition

Raleigh Cline

Sheldon and Janine Maier

William Aldridge

Matthew St. John

Robert Stickler

Gordon and Judy Olson

Paul Overmeyer

Daniel Gross

Kent Eddy

Rudd Van Dyne

Dean Race

Robert Hiltunen

Sumitomo Metal Mining Pogo LLC

Billy Dobson

Doug Baker

Mud Miners LLC

Richard Ott

Richard Swenson and Kelly Williams

Richard Wilder

Terry Russel

Derek Magnuson

Vasiliy Malik

Chris Groppel

Ronald Bingham

Airport Equipment Rentals

Jacob Eisel

Buckeye Land and Minerals Inc.

Larry Nelson

Nelson Mining Co.

Valdez Creek Mining

William McDonald

Ascension LLC

Jim Balderson

Eric Pyne

Boreal Resources Inc.

James and Lorna Lounsbury

Joe Coup and Anna Guildersleve

Ronald Maclaren

Macish Mining LLC

Teck Alaska Inc.

Teresa Winter

Wade Peterson

Robert Roberts

Barbara Wright
Region

Creek, River, or Mine

Eastern Interior

Eastern Interio

Eastern Interior

Eastern Interior

Eastern Interior

Eastern Interior

Eastern Interior

Eastern Interior

Eastern Interio

Eastern Interior

Eastern Interior

Eastern Interior

Eastern Interior

Eastern Interior

Eastern Interior

Eastern Interior

Eastern Interior

Eastern Interior

Eastern Interior

Eastern Interior

Eastern Interior

Eastern Interior

Eastern Interior

Eastern Interio

Eastern Interior

Eastern Interior

Eastern Interio

Eastern Interior

Eastern Interior

Eastern Interior

Eastern Interior

Eastern Interior

Eastern Interior

Eastern Interior

Eastern Interior

Eastern Interior

Eastern Interior

Eastern Interio

Eastern Interio

Eastern Interior

Eastern Interior

Eastern Interio

Northern

Northern

Northern

Northern

Northern

South-central

South-central

South-central

South-central

Ester Dome

Cherry Creek

Gilliland Creek

Jack Wade Creek

Walker Fork

Upper Woods Creek

Napoleon Creek

Walker Fork

George Creek

Eagle Creek

Montana Creek

Poker Creek

McArthur Creek

Fortymile River

Jack Wade Creek

Fortymile River

Jack Wade Creek,

Near Goodpaster River

Pogo Mine

Sullivan Creek

Omega Creek

Doric Creek

Little Boulder Creek

Boulder Creek

Candle Creek

Butte Creek

Tenderfoot Creek

Tenderfoot Creek

Fish Creek

Olive Creek

Livengood Creek

White Creek

Grogg Creek

Union Gulch

Eagle Creek

Chapman Creek

Red Dog Mine

Quartz Creek

Gulch Creek

Sheep Mountain

Bear Creek
District

Type of Operation

Franklin Creek, Ingle Creek

Stonehouse Creek area

Canyon Creek, Hall Creek

No name (near Cherry Creek)

North Fork Fortymile River

North Fork Fortymile River

South Fork Fortymile River

South Fork Fortymile River

Glen Gulch, Rhode Island Creek

Valdez Creek

California Creek, Jim Pup Creek

South Fork Koyukuk River,
Fortymile

Fortymile

Fortymile

Fortymile

Fortymile

Fortymile

Fortymile

Fortymile

Fortymile

Fortymile

Fortymile

Fortymile

Fortymile

Fortymile

Fortymile

Fortymile

Fortymile

Fortymile

Fortymile

Fortymile

Fortymile

Fortymile

Fortymile

Goodpaster

Goodpaster

Hot Springs

Hot Springs

Hot Springs

Hot Springs

Hot Springs

Hot Springs

Melozitna

Rampart

Richardson subdistrict Open-pit placer

Tolovana

Tolovana

Tolovana

Open-pit placer

Tolovana

Valdez Creek

Valdez Creek

Valdez Creek

Koyukuk

Koyukuk

Koyukuk

Koyukuk

Noatak

Hope \& Seward

Hope \& Seward

Hope \& Seward

Hope \& Seward
Open-pit placer
Open-pit placer

Open-pit placer

Suction dredge (6), recreational Open-pit placer

Open-pit placer

Open-pit placer

Open-pit placer

Open-pit hardrock

pen-pit placer

Open-pit placer

Open-pit placer(?)

Suction dredge $(<6)$, recreational 


\section{Operator}

Kristopher Devault

Cal Myrick

Andrew Zielinski

Linda Henderson

Jeremy Harrell

\section{Richard Peterson}

Burke Waldron

Daniel Rodrique

Dennis Boyce

Busch Creek Mining

Bryan Zaher

Daniel Hartman

Doug Grey III

Cripple Creek Mining

James McCall

Jeremy Ellis

Kenneth Lee

KenWin Enterprises

Lee Wilson

Waterstone

Matthew Branson

Michael Just

Nicole Smith

Robert Munk

Samuel Turner

Lloyd Leach

Ella Palmquist

Eugene Olson

Hecla Greens Creek Mining Co.

Ronald \& Marlys Miner

Coeur Alaska, Inc.

Andrea Stevens

L.E. Wyrick

Max Agoff

Prince Creek Mining

Aron Staratt

Moore Creek Pay to Mine

WestMountain Gold

Placer Fields LLC

James and Kathleen Hansen

Kevin Greenfield

Taiga Mining

Charles Merrit

Stampede Gold Resources

Daniel Plano

Kyle Rosander

Rosander Mining

Neil Rosander

Pan Pacific Resources

Paul Sayer

Bedrock Creek Mining

N.B. Tweet

N.B. Tweet \& Sons LLC

James Tweto

Three Ungalik Sisters LLC

Dennis Barron

Robert Murray

Brad Branson

Bradley Kelly

Daniel Purcell

David Young

Grant Wilkins

Greg Jackson
Region

South-central

South-central

South-central

South-central

South-central

South-central

South-central

South-central

South-central

South-central

South-central

South-central

South-central

South-central

South-central

South-central

South-central

South-central

South-central

South-central

South-central

South-central

South-central

South-central

Southeastern

Southeastern

Southeastern

Southwestern

Southwestern

Southwestern

Southwestern

Southwestern

Southwestern

Western

Western

Western

Western

Western

Western

Western

Western

Western

Western

Western

Western

Western

Western

Western

Western

Western

Western

Western

Creek, River, or Mine

District

Type of Operation

Gulch Creek

Canyon Creek

Gulch Creek

Gulch Creek

Seattle Creek

Willow Creek

Red Fox Creek

Tyone Creek

Busch Creek

Willow Creek

Cache Creek

Bird Creek

Ruby Creek

Columbia Creek

Cache Creek

Nugget Creek

Cache Creek

Lewis River

Twin Creek

Coal Creek

Cache Creek

Poorman Creek

Thunder Creek

Luck Creek

Greens Creek Mine

Klehini River

Kensington Gold Mine

Marvel Creek

Granite Creek

Prince Creek

Yankee Creek

Moore Creek

Terra (exploration project)

Candle Creek

Gold Run

Dry Creek, Clear Creek

Ophir Creek, Little Creek

Anvil Creek

Colorado Creek

Colorado Creek

Innoko River

Bedrock Creek

Kougarok River

Bonanza Creek (on Ungalik River)

Goose Creek

Tripple Creek

Norton Sound

Norton Sound

Norton Sound

Norton Sound

Norton Sound

Norton Sound
Hope \& Seward

Hope \& Seward

Hope \& Seward

Hope \& Seward

Hope \& Seward

Nelchina

Valdez Creek

Valdez Creek

Valdez Creek

Willow Creek

Yentna

Yentna

Yentna

Yentna

Yentna

Yentna

Yentna

Yentna

Yentna

Yentna

Yentna

Yentna

Yentna

Yentna

Juneau \& Admiralty

Juneau partial

Juneau partial

Aniak

Aniak

Iditarod

Innoko

Innoko

McGrath

Fairhaven-Candle

Fairhaven-Inmachuk

Hughes

Innoko

Innoko

Innoko

Innoko

Innoko

Innoko

Kougarok

Koyuk

Nome

Nome

Nome

Nome

Nome

Nome

Nome

Nome
Suction dredge $(<6)$, recreational Suction dredge $(3,6)$, recreational Suction dredge (4), recreational Suction dredge (4), recreational Suction dredge $(4,4,6)$, recreational

Open-pit placer

Open-pit placer

Open-pit placer

Open-pit placer

Suction dredge (6), recreational Open-pit placer

Open-pit placer

Open-pit placer

Open-pit placer

Open-pit placer

Open-pit placer

Open-pit placer

Open-pit placer

Open-pit placer

Open-pit placer

Open-pit placer

Open-pit placer, suction

dredge $(<6)$, recreational

Suction dredge $(<6)$, recreational

Suction dredge $(3,5)$, recreational

Underground hardrock

Open-pit placer

Underground hardrock

Open-pit placer

Open-pit placer

Open-pit placer

Open-pit placer

Open-pit placer

Processed from bulk sample, hardrock

Open-pit placer

Open-pit placer

Open-pit placer

Open-pit placer

Open-pit placer

Open-pit placer

Open-pit placer

Open-pit placer

Open-pit placer

Open-pit placer

Open-pit placer

Open-pit placer

Open-pit placer

Suction dredge

Suction dredge

Suction dredge

Suction dredge

Suction dredge

Suction dredge 
Operator

\begin{tabular}{|c|c|}
\hline $\begin{array}{l}\text { Igor Sudarkin } \\
\text { Pacifica }\end{array}$ & Western \\
\hline James Jell & Western \\
\hline Joel Pellegrino & Western \\
\hline $\begin{array}{l}\text { John Byer } \\
\text { Bluewater Gold Alaska Inc. }\end{array}$ & Western \\
\hline Kenneth Scott & Western \\
\hline Kevin Bopp & Western \\
\hline Kris Mclinn & Western \\
\hline Lawrence Dodge & Western \\
\hline $\begin{array}{l}\text { Lonnie Fausett } \\
\text { Midway Mining }\end{array}$ & Western \\
\hline $\begin{array}{l}\text { Michael Benchoff } \\
\text { Subsistence Placers }\end{array}$ & Western \\
\hline Mikel Henry & Western \\
\hline Richard Goodson & Western \\
\hline Robert Rosa & Western \\
\hline William Fitzhugh & Western \\
\hline William Osborne & Western \\
\hline Craig Coggins & Western \\
\hline $\begin{array}{l}\text { Aaron Gustafson } \\
\text { Rayson }\end{array}$ & Western \\
\hline Bryan Nowland & Western \\
\hline Jan Siks & Western \\
\hline Ladislav Sedlak & Western \\
\hline Nicholas Klescewski & Western \\
\hline Norman Haag & Western \\
\hline $\begin{array}{l}\text { Richard Markley } \\
\text { NLT Mining }\end{array}$ & Western \\
\hline Ryan Swanson & Western \\
\hline Spencer Phillips & Western \\
\hline Susan Nowland & Western \\
\hline Thomas Green & Western \\
\hline Sea Gold & Weste \\
\hline Daniel Rhea & Western \\
\hline $\begin{array}{l}\text { Robert Scott } \\
\text { K\&S Leasing }\end{array}$ & Western \\
\hline $\begin{array}{l}\text { David McCully } \\
\text { Bering Subsea Mining LLC }\end{array}$ & Weste \\
\hline $\begin{array}{l}\text { Bill Ellis } \\
\text { Solomon Gold }\end{array}$ & Weste \\
\hline Derek McLarty & Weste \\
\hline $\begin{array}{l}\text { Floyd Ehmann } \\
\text { Dry Creek Valley Mining LLC }\end{array}$ & Weste \\
\hline Jason Bowman & Weste \\
\hline $\begin{array}{r}\text { Thomas Palmer } \\
\text { Palmerosa-IDS }\end{array}$ & Weste \\
\hline Adam Kerner & Weste \\
\hline Steve Phillips and Spencer Phillips & Weste \\
\hline Don Cervin & Weste \\
\hline Mark Gumaer & Weste \\
\hline Robin Gumaer & Weste \\
\hline
\end{tabular}

Creek, River, or Mine

Norton Sound

Norton Sound

Norton Sound

Norton Sound

Norton Sound

Norton Sound

Norton Sound

Norton Sound

Norton Sound

Norton Sound

Norton Sound

Norton Sound

Norton Sound

Norton Sound

Norton Sound

Norton Sound

Norton Sound

Norton Sound

Norton Sound

Norton Sound

Norton Sound

Norton Sound

Norton Sound

Norton Sound

Norton Sound

Norton Sound

Norton Sound

Norton Sound

Norton Sound

Norton Sound

Norton Sound

Norton Sound

Norton Sound

Norton Sound

Norton Sound

Norton Sound

Norton Sound

Casadepaga River,

Lower Willow Creek

No name (near Monument Rocks)

Dick Creek

Dick Creek

District

Type of Operation

Nome

Nome

Nome

Nome

Nome

Nome

Nome

Nome

Nome

Nome

Nome

Nome

Nome

Nome

Nome

Nome

Nome

Nome

Nome

Nome

Nome

Nome

Nome

Nome

Nome

Nome

Nome

Nome

Nome

Nome

Nome

Nome

Nome

Nome

Nome

Nome

Nome

Nome

Ruby

Serpentine

Serpentine
Suction dredge

Suction dredge

Suction dredge

Suction dredge

Suction dredge

Suction dredge

Suction dredge

Suction dredge

Suction dredge

Suction dredge

Suction dredge

Suction dredge

Suction dredge

Suction dredge

Suction dredge

Suction dredge (20)

Suction dredge ( 6 - 17.5), bucket dredge

Suction dredge (6), recreational Suction dredge (6), recreational Suction dredge (6), recreational Suction dredge (6), recreational Suction dredge (6), recreational Suction dredge (6), recreational

Suction dredge (6), recreational Suction dredge (6), recreational Suction dredge (6), recreational Suction dredge (6), recreational Suction dredge $(6,8)$

Suction dredge (8)

Suction dredge (8)

Suction dredge $(8,10,10)$

Suction dredge $(8,18)$

Suction dredge $(8,18)$

Suction dredge $(8,8)$

Suction dredge $(8,8)$

Suction dredge (9)

Suction dredge, large $(6,8)$

Suction dredge, recreational

Open-pit placer

Open-pit placer

Open-pit placer 
APPENDIX C

Primary metals production in Alaska, 1880-2014 ${ }^{\mathrm{a}, \mathrm{b}}$

\begin{tabular}{|c|c|c|c|c|c|c|c|c|c|c|c|c|c|c|c|c|c|c|c|c|}
\hline \multirow{2}{*}{ Year } & \multicolumn{2}{|c|}{ Gold $^{b}$} & \multicolumn{2}{|c|}{ Silver } & \multicolumn{2}{|c|}{ Mercury } & \multicolumn{2}{|c|}{ Antimony } & \multicolumn{2}{|c|}{ Tin } & \multicolumn{2}{|c|}{ Lead } & \multicolumn{2}{|c|}{ Zinc } & \multicolumn{2}{|c|}{ Platinum $^{d}$} & \multicolumn{2}{|l|}{ Copper } & \multicolumn{2}{|c|}{ Chromium } \\
\hline & (oz) & (m\$s) & (oz) & $(\mathrm{t} \mathbf{s})$ & (flask $\left.{ }^{c}\right)$ & $(\mathrm{t} \hat{\mathbf{s}})$ & (lb) & $(\mathrm{t} \$)$ & (lb) & $(\mathrm{t} \$)$ & (tons) & $(\mathrm{t} \$)$ & (tons) & $(t \$)$ & (oz) & $(t \mathbf{s})$ & (lb) & (m\$) & (tons) & $(\mathrm{t} \mathbf{s})$ \\
\hline $1880-99$ & $1,153,889$ & $\$ 23.9$ & 496,101 & $\$ 329.0$ & & $\cdots$ & -- & - & -- & $\cdots$ & 250 & $\$ 17.0$ & $\ldots$ & - & $\cdots$ & - & - & $\cdots$ & $\cdots$ & $\cdots$ \\
\hline 1900-09 & $6,673,173$ & 137.9 & $1,324,580$ & 779.5 & -. & -. & -. & -. & 304,000 & $\$ 112.2$ & 369 & 32.8 & -. & -. & -. & -. & $29,549,486$ & $\$ 4.8$ & -. & -. \\
\hline 1910-19 & $7,209,094$ & 149.0 & $7,058,235$ & $5,107.5$ & -. & -. & $2,760,000$ & w & $1,640,000$ & 805.9 & 3,565 & 470.2 & -. & -. & 914 & $\$ 116.5$ & $515,253,817$ & 109.9 & 2,200 & w \\
\hline $1920-29$ & $3,373,336$ & 69.8 & $6,407,375$ & $5,160.8$ & 117 & $\$ 7.6$ & w & w & 317,800 & 163.9 & 7,961 & $1,084.1$ & -. & -. & 5,750 & 484.9 & $643,576,929$ & 93.3 & -- & -. \\
\hline 1930-39 & $5,345,205$ & 150.8 & $3,250,173$ & $1,889.8$ & 31 & 2.3 & $1,616,000$ & $\$ 228.3$ & $1,024,400$ & 502.1 & 10,791 & 914.3 & -. & -. & 102,615 & $5,427.1$ & $184,522,000$ & 19.5 & & \\
\hline |1940-49 & $3,137,447$ & 109.8 & 794,842 & 577.0 & 3,094 & 724.3 & $2,062,080$ & 311.1 & 319,200 & 230.3 & 3,096 & 405.2 & 678 & $\$ 0.5$ & 225,285 & 12,623.3 & 433,700 & 0.2 & 7,409 & $\$ 250.9$ \\
\hline $1950-59$ & $2,297,827$ & 80.6 & 321,669 & 292.9 & 18,185 & $4,370.0$ & $2,663,520$ & $3,697.6$ & $1,144,000$ & $1,310.5$ & 177 & 38.6 & -- & -- & 107,927 & $9,403.9$ & 106,000 & 0.1 & 21,442 & $1,975.8$ \\
\hline $1960-69$ & 751,870 & 26.6 & 59,300 & 70.7 & 13,996 & $3,098.0$ & 228,800 & 267.8 & -. & & 40 & 9.9 & -. & -. & 111,556 & $13,618.5$ & 352,000 & 0.1 & & \\
\hline $1970-79$ & 324,906 & 55.8 & 54,700 & 250.5 & 4,040 & $1,694.0$ & $1,473,000$ & $\begin{array}{l}1,714.0 \\
\end{array}$ & 166,000 & 949.0 & 20 & 8.0 & -. & -. & 41,604 & $6,826.0$ & -. & -. & 8,000 & $1,200.0$ \\
\hline 1980 & 75,000 & 32.0 & 7,500 & 111.0 & -. & -. & -- & -. & 120,000 & 984.0 & 31 & 29.0 & -. & -- & -- & & -. & -. & -. & -. \\
\hline 1981 & 134,200 & 55.2 & 13,420 & 111.3 & w & w & -- & -. & 106,000 & 700.0 & -. & -. & -. & -- & 900 & 200.0 & -. & -. & -. & -. \\
\hline 1982 & 175,000 & 69.9 & 22,000 & 198.0 & -. & . & -. & -. & 198,000 & $1,365.0$ & -. & -. & -. & -. & w & w & -. & -. & -. & -. \\
\hline 1983 & 169,000 & 67.6 & 33,200 & 332.0 & -. & -. & 22,400 & 45.0 & 215,000 & $1,100.0$ & -. & -. & -. & -. & w & w & -. & -. & -. & -. \\
\hline 1984 & 175,000 & 62.1 & 20,000 & 159.0 & 5 & 1.5 & 135,000 & 225.8 & 225,000 & 400.0 & -. & -. & -. & -. & w & w & -. & -. & -. & -. \\
\hline 1985 & 190,000 & 61.2 & 28,500 & 171.0 & 27 & 10.0 & 65,000 & 98.0 & 300,000 & 650.0 & -. & -. & -. & .. & .. & -. & .. & .. & .. & .. \\
\hline 1986 & 160,000 & 60.8 & 24,000 & 134.4 & 12 & 2.8 & 45,000 & 67.5 & 340,000 & 890.0 & -. & -. & -. & -. & w & w & -. & -. & -. & -. \\
\hline 1987 & 229,707 & 104.5 & 54,300 & 391.0 & & & & & 288,000 & 460.0 & -. & -- & -- & -. & w & w & -. & -. & -. & -. \\
\hline 1988 & 265,500 & 112.8 & 47,790 & 282.0 & w & w & -- & -. & 300,000 & 950.0 & -. & -. & -. & -- & 25 & 13.8 & -. & -. & -. & -. \\
\hline 1989 & 284,617 & 108.7 & $5,211,591$ & $27,300.0$ & -. & -. & -. & -. & 194,000 & 672.0 & 9,585 & $7,700.0$ & 19,843 & $29,400.0$ & -. & -. & -. & -. & -. & -. \\
\hline 1990 & 231,700 & 89.2 & $10,135,000$ & $50,675.0$ & -. & -. & -. & -. & 57,000 & 200.0 & 44,220 & $30,954.0$ & 181,200 & $253,680.0$ & -. & -. & -. & -. & -. & -. \\
\hline 1991 & 243,900 & 88.3 & $9,076,854$ & $39,110.0$ & -. & -. & -. & -. & 6,800 & 22.1 & 69,591 & $33,403.7$ & 278,221 & $278,221.0$ & 15 & 5.3 & -. & -. & -. & -. \\
\hline 1992 & 262,530 & 88.5 & $9,115,755$ & $34,913.0$ & -. & -. & -- & -. & 1,500 & 5.9 & 68,664 & $31,585.0$ & 274,507 & $301,957.7$ & -. & -- & -. & -. & -. & -. \\
\hline 1993 & 191,265 & 68.6 & $5,658,958$ & $24,333.0$ & -. & -. & -. & -. & 21,000 & 50.6 & 38,221 & $13,759.6$ & 268,769 & $236,516.7$ & 3 & 1.2 & -. & -. & -. & -. \\
\hline 1994 & 182,100 & 70.3 & 1,968,000 & $\begin{array}{l}10,391.0 \\
\end{array}$ & -. & -. & -. & -. & 21,000 & 0.0 & 36,447 & $25,512.9$ & 329,003 & $296,102.7$ & 5 & 2.1 & -. & -. & -. & -. \\
\hline 1995 & 141,882 & 56.0 & $1,225,730$ & $6,655.0$ & -. & -. & -. & -. & -. & -. & 58,098 & $34,428.6$ & 359,950 & $345,552.0$ & 1 & 0.4 & -. & 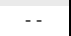 & -. & -. \\
\hline 1996 & 161,565 & 62.6 & $3,676,000$ & $19,078.0$ & -. & -. & -. & -. & -. & -. & 70,086 & $52,284.0$ & 366,780 & $361,646.0$ & 2 & 0.8 & 780,000 & 0.8 & -. & -. \\
\hline 1997 & 590,516 & 207.3 & $14,401,165$ & $70,710.0$ & -. & -. & -. & -. & -. & -. & 88,560 & $49,593.0$ & 419,097 & $494,888.0$ & -. & -. & $3,440,000$ & 3.5 & -. & -. \\
\hline 1998 & 594,191 & 174.6 & $14,856,000$ & $82,154.0$ & -. & & -- & -- & -. & -- & 102,887 & $49,386.0$ & 549,348 & $505,400.0$ & & & $3,800,000$ & 2.9 & -. & -. \\
\hline 1999 & 517,890 & 144.3 & $16,467,000$ & $85,628.0$ & -. & -. & -- & -. & -. & .- & 125,208 & $57,596.0$ & 643,642 & $630,769.0$ & -. & -. & $4,200,000$ & 3.0 & -. & -. \\
\hline 2000 & 551,982 & 154.1 & $18,226,615$ & $90,404.0$ & -. & -. & -. & -. & -. & -. & 123,224 & $51,754.0$ & 669,112 & $682,494.0$ & -. & -. & $2,800,000$ & 2.3 & -. & -. \\
\hline 2001 & 550,644 & 149.3 & $16,798,000$ & $73,408.0$ & -. & -. & -. & -. & -. & -. & 127,385 & $56,049.0$ & 634,883 & $507,907.0$ & -. & -. & $2,800,000$ & 2.0 & -. & -. \\
\hline 2002 & 562,094 & 174.3 & $17,858,183$ & $82,326.0$ & -. & -. & -. & -. & -. & -. & 146,462 & $61,514.0$ & 718,103 & $502,674.0$ & -. & -. & $3,200,000$ & 2.3 & -. & -. \\
\hline 2003 & 528,191 & 191.9 & $18,589,100$ & $95,300.0$ & -. & -. & -- & -. & -. & -. & 162,479 & $64,279.0$ & 714,769 & $536,348.0$ & -. & -. & -. & $-\cdot$ & -. & -. \\
\hline 2004 & 456,508 & 192.3 & $16,947,270$ & $113,056.9$ & -. & -. & -- & -. & -. & -. & 150,796 & $120,636.8$ & 680,015 & $651,432.2$ & -. & -. & -. & -. & -. & -. \\
\hline 2005 & 427,031 & 189.9 & $11,670,000$ & $\begin{array}{r}85,382.0 \\
\end{array}$ & -. & -. & -. & -. & .. & -. & 131,366 & $115,230.0$ & 684,462 & $862,108.0$ & -. & -. & -. & .. & -. & -. \\
\hline 2006 & 570,129 & 344.1 & $16,489,394$ & $190,415.9$ & -. & -. & -. & -. & -. & -. & 157,128 & $183,629.3$ & 673,967 & $2,002,971.4$ & -. & -. & -. & -. & -. & -. \\
\hline 2007 & 726,933 & 511.1 & $20,203,985$ & $270,402.1$ & -. & -. & -. & -. & -. & -. & 167,181 & $389,532.2$ & 696,115 & $2,048,451.6$ & -. & -. & 87,627 & 0.3 & -. & -. \\
\hline 2008 & 800,752 & 698.2 & $14,643,735$ & $219,496.4$ & -. & -. & -. & -. & .. & -. & 153,705 & $287,428.4$ & 626,135 & $1,055,220.1$ & -. & -. & .- & -. & -. & -. \\
\hline 2009 & 780,657 & 759.1 & $15,617,436$ & $229,159.3$ & -. & -. & -. & -. & -. & -. & 167,204 & $260,838.2$ & 712,496 & $1,068,744.0$ & -. & -. & -. & -. & -. & -. \\
\hline 2010 & 914,462 & $1,119.8$ & $13,991,297$ & $282,523.5$ & -. & -. & -. & -. & -. & -. & 146,480 & $284,171.2$ & 667,539 & $1,212,390.3$ & -. & .. & -. & -. & -. & -. \\
\hline 2011 & 848,945 & $1,334.1$ & $11,683,967$ & $410,340.9$ & -. & -. & -. & -. & -. & -. & 113,649 & $247,755.2$ & 696,793 & $1,379,649.2$ & 5,000 & $8,609.3$ & 1,058 & 0.0 & -. & -. \\
\hline 2012 & 921,240 & $1,537.5$ & $12,313,877$ & $383,573.6$ & -. & -. & -. & -. & -. & -. & 126,234 & $234,795.2$ & 647,481 & $1,139,566.6$ & . & & 14,327 & 0.0 & -. & -. \\
\hline 2013 & $1,022,987$ & $1,551.9$ & $13,453,367$ & $320,121.0$ & -. & -. & -. & -. & -. & -. & 126,707 & $245,811.6$ & 665,318 & $1,157,653.3$ & -. & -. & 77,240 & 0.3 & -. & -. \\
\hline 2014 & 948,547 & $1,201.2$ & $15,388,901$ & $304,392.5$ & & & & & & & 155,183 & $294,847.2$ & 716,781 & $1,404,890.4$ & -. & -. &.- & $-\cdot$ & & \\
\hline Other ${ }^{e}$ & & & & & 1,438 & $\cdots$ & -. & -. & -. & -- & & & & & 71,946 & $17,091.9$ &.- & .. & $\ldots$ & $\ldots$ \\
\hline TOTAL & $45,853,413$ & $\$ 12,697.5$ & $345,684,865$ & $\$ 3,617,596.6$ & 40,945 & $\$$ & $11,070,800$ & $\$ 6,655.1$ & $7,287,700$ & $\$ 12,523.5$ & $2,893,050$ & $\$ 3,287,483.1$ & $13,895,007$ & $\$ 19,946,633.7$ & 673,548 & $\$ 57,333.1$ & $1,394,994,184$ & $\$ 245.3$ & 39,051 & $\$ 3,426.7$ \\
\hline
\end{tabular}




\section{APPENDIX D}

Production of industrial minerals, coal, and other commodities in Alaska, 1880-2014, a,b

\begin{tabular}{|c|c|c|c|c|c|c|c|c|c|}
\hline & \multicolumn{2}{|c|}{ Coal } & \multicolumn{2}{|c|}{ Sand and Gravel } & \multicolumn{2}{|l|}{ Rock $^{c}$} & \multicolumn{2}{|c|}{ Barite } & \multirow{2}{*}{$\begin{array}{l}\text { Other }^{d} \\
\$ \$\end{array}$} \\
\hline Year & short tons & $\mathrm{m} \$$ & short tons & $\mathrm{m} \$$ & short tons & $\mathrm{m} \$$ & short tons & $t \$$ & \\
\hline 1880-1899 & 19,429 & $\$ 0.1$ & -- & -- & 7,510 & $\$ 0.0$ & -- & -- & -- \\
\hline 1900-1909 & 33,214 & 0.2 & -- & -- & 15,318 & 0.2 & -- & -- & $\$ 246,403$ \\
\hline 1910-1919 & 210,806 & 1.2 & -- & -- & 50,014 & 0.3 & -- & -- & $2,014,788$ \\
\hline 1920-1929 & 937,860 & 5.2 & -- & -- & 494,417 & 2.7 & -- & -- & $2,523,754$ \\
\hline 1930-1939 & $1,222,797$ & 5.5 & 42,332 & $\$ 0.0$ & 689,676 & 2.8 & -- & - - & 899,767 \\
\hline 1940-1949 & $3,189,026$ & 20.2 & $1,758,504$ & 0.7 & 286,341 & 1.3 & -- & -- & $27,124,158$ \\
\hline 1950-1959 & $6,632,641$ & 59.7 & $65,804,686$ & 55.1 & $1,843,560$ & 5.2 & -- & -- & $25,443,427$ \\
\hline 1960-1969 & $7,849,000$ & 58.8 & $163,315,000$ & 176.7 & $2,034,000$ & 4.2 & 225,000 & $\$ 1,200.0$ & $34,143,000$ \\
\hline 1970-1979 & $7,405,000$ & 89.0 & $489,522,000$ & $1,004.9$ & $47,930,000$ & 137.4 & 502,000 & $8,217.0$ & $77,501,000$ \\
\hline 1980 & 800,000 & 16.0 & $40,000,000$ & 86.0 & $3,700,000$ & 15.4 & 50,000 & $2,000.0$ & 97,500 \\
\hline 1981 & 800,000 & 17.6 & $46,000,000$ & 88.2 & $4,200,000$ & 19.3 & - - & -- & 256,000 \\
\hline 1982 & 830,000 & 18.0 & $45,000,000$ & 91.0 & $3,400,000$ & 15.6 & -- & -- & 150,000 \\
\hline 1983 & 830,000 & 18.0 & $50,000,000$ & 105.0 & $5,270,000$ & 25.0 & -- & -- & 242,000 \\
\hline 1984 & 849,161 & 23.8 & $27,000,000$ & 95.0 & $2,700,000$ & 16.0 & -- & -- & 875,875 \\
\hline 1985 & $1,370,000$ & 39.7 & $28,184,080$ & 112.1 & $2,500,000$ & 12.0 & -- & -- & 559,000 \\
\hline 1986 & $1,492,707$ & 40.1 & $20,873,110$ & 75.8 & $4,200,000$ & 20.3 & -- & -- & 384,800 \\
\hline 1987 & $1,508,927$ & 42.4 & $16,696,374$ & 42.7 & $1,805,000$ & 11.6 & - - & -- & 388,400 \\
\hline 1988 & $1,551,162$ & 44.3 & $17,264,500$ & 48.8 & $3,600,000$ & 24.7 & -- & -- & 389,000 \\
\hline 1989 & $1,452,353$ & 41.5 & $14,418,000$ & 39.9 & $2,914,000$ & 20.3 & - - & -- & $1,492,000$ \\
\hline 1990 & $1,576,000$ & 45.0 & $15,013,500$ & 40.8 & $3,200,000$ & 22.1 & -- & -- & 400,000 \\
\hline 1991 & $1,540,000$ & 39.0 & $14,160,011$ & 45.5 & $3,000,000$ & 22.5 & -- & -- & 462,000 \\
\hline 1992 & $1,531,800$ & 38.3 & $14,599,746$ & 42.2 & $2,900,000$ & 23.0 & -- & -- & 430,000 \\
\hline 1993 & $1,586,545$ & 38.1 & $13,162,402$ & 40.6 & $3,561,324$ & 26.2 & -- & - - & 465,000 \\
\hline 1994 & $1,490,000$ & 36.8 & $13,518,321$ & 41.0 & $3,843,953$ & 27.0 & -- & -- & 459,500 \\
\hline 1995 & $1,640,000$ & 41.3 & $9,847,550$ & 30.9 & $2,811,152$ & 22.1 & -- & -- & 182,500 \\
\hline 1996 & $1,481,000$ & 38.0 & $9,890,463$ & 32.2 & $3,000,045$ & 23.6 & -- & -- & 200,000 \\
\hline 1997 & $1,446,000$ & 38.1 & $13,800,000$ & 51.9 & $3,200,000$ & 20.0 & - - & -- & 217,000 \\
\hline 1998 & $1,339,000$ & 35.2 & $12,363,450$ & 57.3 & $1,636,200$ & 14.0 & - - & -- & 215,000 \\
\hline 1999 & $1,560,000$ & 41.1 & $10,600,000$ & 52.4 & $1,640,000$ & 18.0 & - - & -- & 190,000 \\
\hline 2000 & $1,473,355$ & 38.8 & $10,600,000$ & 49.9 & $5,200,000$ & 36.6 & -- & -- & 203,000 \\
\hline 2001 & $1,537,000$ & 48.1 & $10,360,000$ & 55.2 & $3,091,000$ & 27.2 & -- & -- & 205,000 \\
\hline 2002 & $1,158,000$ & 37.4 & $22,412,000$ & 120.7 & $3,152,000$ & 31.4 & -- & -- & 200,000 \\
\hline 2003 & $1,088,000$ & 38.1 & $11,868,001$ & 64.1 & 861,382 & 10.4 & -- & -- & 175,000 \\
\hline 2004 & $1,450,000$ & 50.8 & $19,576,092$ & 101.5 & $7,312,050$ & 106.2 & -- & -- & $2,732,554$ \\
\hline 2005 & $1,402,174$ & 49.1 & $16,620,009$ & 76.5 & $2,803,172$ & 22.6 & -- & -- & 809,642 \\
\hline 2006 & $1,397,500$ & 48.9 & $13,953,465$ & 63.4 & $2,369,738$ & 23.8 & -- & -- & $1,057,500$ \\
\hline 2007 & $1,273,004$ & 44.6 & $14,163,676$ & 76.1 & $2,211,954$ & 25.5 & -- & -- & $1,085,500$ \\
\hline 2008 & $1,538,000$ & 53.8 & $12,461,685$ & 72.4 & $2,485,820$ & 39.5 & -- & -- & $1,159,502$ \\
\hline 2009 & $1,861,714$ & 65.2 & $7,072,037$ & 41.4 & $1,837,090$ & 27.2 & -- & -- & $3,678,930$ \\
\hline 2010 & $2,061,000$ & 72.1 & $6,977,297$ & 48.0 & 290,852 & 4.3 & - - & - - & $2,303,950$ \\
\hline 2011 & $2,220,000$ & 77.7 & $5,862,851$ & 38.7 & 499,722 & 6.4 & -- & - - & $3,200,000$ \\
\hline 2012 & $2,018,759$ & 70.7 & $7,799,994$ & 52.3 & $1,050,762$ & 15.8 & -- & -- & -- \\
\hline 2013 & $1,600,000$ & 56.0 & $11,622,045$ & 79.6 & 364,632 & 5.5 & -- & -- & $1,900,000$ \\
\hline 2014 & $1,500,000$ & 52.5 & 526,509 & 6.8 & $1,147,869$ & 17.2 & -- & -- & 120,000 \\
\hline Other & -- & -- & -- & -- & $2,300,000^{\mathrm{e}}$ & W & 79,000 & W & -- \\
\hline TOTAL & $77,752,934$ & $\$ 1,735.6$ & $1,324,709,689$ & $\$ 3,403.2$ & $153,410,553$ & $\$ 952.5$ & 856,000 & $\$ 11,417.0$ & $\$ 196,782,450$ \\
\hline \multicolumn{10}{|c|}{ a From published and unpublished state and federal documents. Where state and federal figures differ significantly, state figures are used. } \\
\hline \multicolumn{10}{|c|}{ b Please refer to previous editions of this appendix for year-to-year production information for years 1900 to 1979.} \\
\hline \multicolumn{10}{|c|}{ c Building-stone production figures for $1880-1937$ are for the southcentral and interior regions of Alaska only. } \\
\hline \multicolumn{10}{|c|}{$\begin{array}{l}\text { d Includes } 2.4 \text { million lb U } \mathrm{O}_{8} \text { (1955-1971); 505,000 tons gypsum (1905-1926); 286,000 lb WO (intermittently, 1916-1980); } 94,000 \mathrm{lb} \text { asbestos (1942-44); 540,000 lb graphite (1917-1918 and 1942-1950); } \\
\text { and undistributed amounts of zinc, jade, peat, clay, soapstone, miscellaneous gemstones, and other commodities (1880-present). }\end{array}$} \\
\hline \multicolumn{10}{|c|}{ e Marble quarried on Prince of Wales Island, southeastern Alaska (1900-1941). } \\
\hline \multicolumn{10}{|l|}{$\mathrm{m} \$=$ million dollars } \\
\hline \multicolumn{10}{|c|}{$\mathrm{t} \$=$ thousand dollars } \\
\hline \multicolumn{10}{|l|}{$--=$ not reported } \\
\hline W = withheld & & & & & & & & & \\
\hline
\end{tabular}




\section{APPENDIX E \\ Resources related to the Minerals Industry in Alaska}

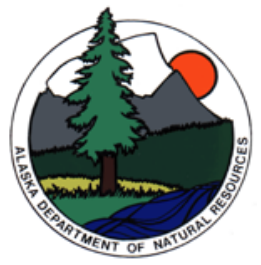

\section{DEPARTMENT OF NATURAL RESOURCES}

- Recording Fees http://dnr.alaska.gov/ssd/recoff/fees_RO.cfm

- Public Information Center http://dnr.alaska.gov/commis/pic/

- State Uniform Commercial Code (UCC) Documents Search http://dnr.alaska.gov/ssd/recoff/

\section{Division of Mining, Land \& Water}

- Mining Applications and Forms http://dnr.alaska.gov/mlw/forms/

- Fact Sheets http://dnr.alaska.gov/mlw/factsht/

- Annual Placer Mining Application (APMA) 2015 http://dnr.alaska.gov/mlw/forms/14apma/

- Annual Rental http://dnr.alaska.gov/mlw/factsht/mine_fs/annualre.pdf

- Leasing State Land http://dnr.alaska.gov/mlw/factsht/land_fs/lease_land.pdf

- Land Lease \& Contract Payment Information http://dnr.alaska.gov/mlw/factsht/land_fs/lease_contract_pavment_info.pdf

- Production Royalty http://dnr.alaska.gov/mlw/factsht/mine_fs/producti.pdf

- DNR Production Royalty Form http://dnr.alaska.gov/mlw/forms/mining/royalty_fm.pdf

- Exploration Incentive Credit Program http://dnr.alaska.gov/mlw/factsht/mine_fs/explore.pdf

\section{Division of Geological \& Geophysical Surveys}

- Publications On-Line http://dggs.alaska.gov/publications/

- Interactive Maps http://maps.dggs.alaska.gov/

- Geologic Maps of Alaska: Online Map Search Tool http://maps.dggs.alaska.gov/mapindex/

- Unpublished Geology-Related Data (Alaska Geologic Data Index) http://maps.dggs.alaska.gov/agdi/

- Geologic Materials Center http://dggs.alaska.gov/gmc/

- Geochemical Sample Analysis Search (WebGeochem) http://www.dggs.alaska.gov/webgeochem/

- Minerals Report Questionnaire http://www.dggs.alaska.gov/minerals questionnaire

Alaska's Minerals Data and Information Rescue in Alaska (MDIRA) Project Websites

- MDIRA Portal Home Page http://akgeology.info/

- Alaska Mining Claims Information System http://akmining.info/

- Land Records Web Application http://dnr.alaska.gov/Landrecords/

- State Recorder's Office Search http://dnr.alaska.gov/ssd/recoff/searchRO.cfm

- Alaska Resource Data Files http://ardf.wr.usgs.gov/

- USGS Alaska Geochemical Database (NURE, RASS, PLUTO, etc.) http://pubs.usgs.gov/ds/637/

- Guide to Alaska Geologic and Mineral Information http://dx.doi.org/10.14509/3318

- State Geo-Spatial Data Clearinghouse http://www.asgdc.state.ak.us/

\section{ALASKA} DEPAR TME N T O OF C O M M U N I T Y, AND ECONOMIC DEVELOPMENT

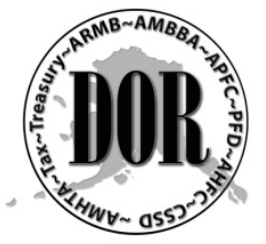

\section{DEPARTMENT OF COMMERCE, COMMUNITY, AND ECONOMIC DEVELOPMENT}

- Minerals Information https://www.commerce.alaska.gov/web/ded/dev/mineralsdevelopment

- Community and Regional Information https://www.commerce.alaska.gov/web/dcra/ResearchAnalysis

- Alaska Industrial Development and Export Authority (AIDEA) http://www.aidea.org

- AIDEA Supports Mining www.aidea.org/Programs/ProjectDevelopment/30YearsofMiningSupport

\section{DEPARTMENT OF REVENUE}

- Mining License Tax http://www.tax.alaska.gov/programs/programs/index.aspx?60610

- Motor Fuel Tax Claim for Refund http://www.tax.alaska.gov//programs/programs/forms/index.aspx?60210

- Alaska Motor Fuel Tax Instructions http://www.tax.alaska.gov/programs/documentviewer/viewer.aspx?5086f 
APPENDIX F

Identified mineral resources of Alaska deposits

\begin{tabular}{|c|c|c|c|c|c|c|c|c|c|c|c|c|c|c|c|c|c|c|c|}
\hline $\begin{array}{l}\text { DEPOSIT- } \\
\text { Type- } \\
\text { Metal Suite }\end{array}$ & PHASE & CATEGORY & $\begin{array}{l}\text { TONS OF } \\
\text { RESOURCE }\end{array}$ & $\begin{array}{l}\mathrm{Cu} \\
\%\end{array}$ & \begin{tabular}{|c|}
$\mathrm{Cu}$ \\
thousand \\
pounds
\end{tabular} & $\begin{array}{l}\mathrm{Pb} \\
\%\end{array}$ & \begin{tabular}{|c|}
$\mathrm{Pb}$ \\
thousand \\
pounds
\end{tabular} & $\begin{array}{l}\mathrm{zn} \\
\%\end{array}$ & $\begin{array}{c}\mathrm{Zn} \\
\text { thousand } \\
\text { pounds }\end{array}$ & $\begin{array}{c}\mathrm{Au} \\
\text { oz/ton }\end{array}$ & \begin{tabular}{|c|} 
Au \\
thousand \\
ounces
\end{tabular} & $\begin{array}{c}\mathrm{Ag} \\
\mathrm{oz} / \mathrm{ton}\end{array}$ & \begin{tabular}{|c|}
$\mathrm{Ag}$ \\
thousand \\
ounces
\end{tabular} & $\begin{array}{l}\text { Mo } \\
\%\end{array}$ & \begin{tabular}{|c|} 
Mo \\
thousand \\
pounds
\end{tabular} & $\begin{array}{c}\text { TREO+Y } \\
\%\end{array}$ & \begin{tabular}{|c|} 
TREO+Y \\
thousand \\
pounds
\end{tabular} & $\begin{array}{c}\text { Graphite } \\
\%\end{array}$ & $\begin{array}{l}\text { Graphite } \\
\text { thousand } \\
\text { Pounds }\end{array}$ \\
\hline \multicolumn{20}{|c|}{ KENSINGTON - Gold veins - Precious metals (gold) } \\
\hline & Production (Kensington) & Proven & 400,000 & & & & & & & 0.180 & 72.0 & & & & & & & & \\
\hline & Production (Raven) & Proven & 17,000 & & & & & & & 0.412 & 7.0 & & & & & & & & \\
\hline & Production (Kensington) & Probable & $2,824,000$ & & & & & & & 0.181 & 512.0 & & & & & & & & \\
\hline & Production (Raven) & Probable & 162,000 & & & & & & & 0.241 & 39.0 & & & & & & & & \\
\hline & Production (Kensington) & Measured & 177,000 & & & & & & & 0.260 & 46.0 & & & & & & & & \\
\hline & Production (Raven) & Measured & 4,000 & & & & & & & 0.244 & 1.0 & & & & & & & & \\
\hline & Production (Kensington) & Indicated & $1,292,000$ & & & & & & & 0.241 & 312.0 & & & & & & & & \\
\hline & Production (Raven) & Indicated & 93,000 & & & & & & & 0.258 & 24.0 & & & & & & & & \\
\hline & Production (Kensington) & Inferred & $1,265,000$ & & & & & & & 0.296 & 375.0 & & & & & & & & \\
\hline & Production (Raven) & linferred & 68,000 & & & & & & & 0.235 & 16.0 & & & & & & & & \\
\hline & Advanced Exploration (Jualin) & Inferred & 289,000 & & & & & & & 0.619 & 179.0 & & & & & & & & \\
\hline & & Total & $6,591,000$ & & & & & & & 0.240 & $1,583.0$ & & & & & & & & \\
\hline \multicolumn{20}{|c|}{ LMS - Gold veins - Precious metals (gold) } \\
\hline & Exploration $(0.5 \mathrm{~g} / \mathrm{t}$ Au cut-off, open pit & Inferred & $9,170,000$ & & & & & & & $0.029 \mid$ & 267.0 & & & & & & & & \\
\hline \multicolumn{20}{|c|}{\begin{tabular}{|l}
$\mid$ Exploration (0.5/ / t tuu cut-off open pit) \\
POGO - Gold veins - Precious metals (gold)
\end{tabular}} \\
\hline & Production & Probable & & & & & & & & & $1,768.3$ & & & & & & & & \\
\hline & Production & Indicated & & & & & & & & & $2,732.8$ & & & & & & & & \\
\hline & & Total & & & & & & & & & $4,501.1$ & & & & & & & & \\
\hline \multicolumn{20}{|c|}{ TERRA - Gold veins - Precious metals (gold, silver) } \\
\hline & Exploration (5 g/tonne Au cut-off) & Indicated & 128,913 & & & & & & & 0.387 & 49.8 & 0.88 & 112.7 & & & & & & \\
\hline & Exploration ( $5 \mathrm{~g} /$ tonne Au cut-off) & Inferred & 811,286 & & & & & & & 0.456 & 369.8 & 0.81 & 653.9 & & & & & & \\
\hline & & Total & 940,199 & & & & & & & 0.446 & 419.6 & 0.82 & 766.6 & & & & & & \\
\hline WILLOW (Luck & Shot) - Gold veins - Precious met & & & & & & & & & & & & & & & & & & \\
\hline & Exploration (7 g/tonne Au cut-off) & Measured & 12,700 & & & & & & & 0.832 & 10.5 & & & & & & & & \\
\hline & Exploration ( $7 \mathrm{~g} /$ /tonne Au cut-off) & Indicated & 74,100 & & & & & & & 0.698 & 51.6 & & & & & & & & \\
\hline & Exploration ( $7 \mathrm{~g} /$ /tonne Au cut-off) & Inferred & 5,800 & & & & & & & 0.707 & 4.1 & & & & & & & & \\
\hline & & Total & 92,600 & & & & & & & 0.715 & 66.2 & & & & & & & & \\
\hline DONLIN - Int & sion gold - Precious metals (gold) & & & & & & & & & & & & & & & & & & \\
\hline & Development & Proven & $8,468,971$ & & & & & & & 0.068 & 573.0 & & & & & & & & \\
\hline & Development & Probable & $547,984,194$ & & & & & & & 0.061 & $33,276.0$ & & & & & & & & \\
\hline & Development & Measured & 52,910 & & & & & & & 0.074 & 53.0 & & & & & & & & \\
\hline & Development & Indicated & $40,210,802$ & & & & & & & 0.065 & $5,104.0$ & & & & & & & & \\
\hline & Development & Inferred & $101,649,697$ & & & & & & & 0.059 & $5,993.0$ & & & & & & & & \\
\hline & & Total & $698,366,574$ & & & & & & & 0.061 & $45,000.0$ & & & & & & & & \\
\hline FORT KNOX - & ntrusion gold - Precious metals (go & & & & & & & & & & & & & & & & & & \\
\hline & Production & Proven & $74,796,567$ & & & & & & & 0.012 & 872.0 & & & & & & & & \\
\hline & Production & Probable & $105,808,675$ & & & & & & & 0.014 & $1,526.0$ & & & & & & & & \\
\hline & Production & Measured & $9,276,957$ & & & & & & & 0.012 & 110.0 & & & & & & & & \\
\hline & Production & Indicated & $106,963,885$ & & & & & & & 0.013 & $1,336.0$ & & & & & & & & \\
\hline & Production & Inferred & $14,881,050$ & & & & & & & 0.013 & 189.0 & & & & & & & & \\
\hline & & Total & $311,728,000$ & & & & & & & 0.013 & $2,508.0$ & & & & & & & & \\
\hline GOLDEN SUMI & IIT - Intrusion gold - Precious meta & & & & & & & & & & & & & & & & & & \\
\hline & Exploration (Dolphin oxide deposit) & Indicated & $19,828,580$ & & & & & & & 0.019 & 383.0 & & & & & & & & \\
\hline & Exploration (Dolphin oxide deposit) & Inferred & $11,959,371$ & & & & & & & 0.018 & 208.0 & & & & & & & & \\
\hline & Exploration (Dolphin sulfide deposit) & Indicated & $68,133,163$ & & & & & & & 0.019 & $1,300.0$ & & & & & & & & \\
\hline & Exploration (Dolphin sulfide deposit) & Inferred & $261,476,583$ & & & & & & & 0.018 & $4,637.0$ & & & & & & & & \\
\hline & & Total & $361,397,697$ & & & & & & & 0.018 & $6,528.0$ & & & & & & & & \\
\hline MONEY KNOB & Livengood) - Intrusion gold - Prec & & & & & & & & & & & & & & & & & & \\
\hline & Advanced Exploration & Proven & 478,941,634 & & & & & & & 0.020 & $9,621.5$ & & & & & & & & \\
\hline & Advanced Exploration & Probable & $22,190,181$ & & & & & & & 0.020 & 454.0 & & & & & & & & \\
\hline & Advanced Exploration & Measured & $326,839,666$ & & & & & & & 0.018 & $4,778.5$ & & & & & & & & \\
\hline & Advanced Exploration & Indicated & $\frac{52,00,070}{56,073,119}$ & & & & & & & 0.016 & 846.0 & & & & & & & & \\
\hline & Advanced Exploration & Inferred & $293,211,800$ & & & & & & & 0.015 & $4,400.0$ & & & & & & & & \\
\hline & & Total & $1,177,256,400$ & & & & & & & 0.018 & $20,100.0$ & & & & & & & & \\
\hline NIXON FORK - & Intrusion gold (skarn) - Precious m & & & & & & & & & & & & & & & & & & \\
\hline & Development (past producer) & Indicated & 270,430 & & & & & & & 0.481 & 130.0 & & & & & & & & \\
\hline & Development (past producer) & Inferred & 118,000 & & & & & & & $\frac{0.512}{0.512}$ & 60.5 & & & & & & & & \\
\hline & & Total & 388.430 & & & & & & & $\frac{0.491}{0.491}$ & $\begin{array}{l}190.5 \\
\end{array}$ & & & & & & & & \\
\hline VINASALE - Ir & trusion gold - Precious metals (golc & & & & & & & & & & & & & & & & & & \\
\hline & Exploration & Indicated & $3,760,000$ & & & & & & & 0.043 & 162.0 & & & & & & & & \\
\hline & Exploration & Inferred & $55,340,000$ & & & & & & & 0.031 & $1,703.0$ & & & & & & & & \\
\hline & & Total & $59,100,000$ & & & & & & & 0.032 & $1,865.0$ & & & & & & & & \\
\hline ANARRAQ (Re & Dog satellite) - Massive sulfide - & nc, silver) & & & & & & & & & & & & & & & & & \\
\hline & Exploration & Inferred & $19,000,000$ & & & 4.8 & $1,824,000$ & 15.8 & $6,004,000$ & & & 2.10 & 39,300 & & & & & & \\
\hline ARCTIC - Mas & ive sulfide - Polymetallic (copper, & & & & & & & & & & & & & & & & & & \\
\hline & Advanced Exploration & Indicated & $26,287,650$ & 3.26 & $1,713,000$ & 0.76 & 400,900 & 4.45 & $2,338,000$ & 0.021 & 550.0 & 1.55 & 40,800 & & & & & & \\
\hline & Advanced Exploration & Inferred & $3,707,035$ & 3.22 & 239,000 & 0.58 & 43,200 & 3.84 & 285,000 & 0.017 & 60.0 & 1.21 & 4,500 & & & & & & \\
\hline & & Total & $29,994,685$ & 3.25 & $1,952,000$ & 0.74 & 444,100 & 4.37 & $2,623,000$ & 0.020 & 610.0 & 1.51 & 45,300 & & & & & & \\
\hline
\end{tabular}




\begin{tabular}{|c|c|c|c|c|c|c|c|c|c|c|c|c|c|c|c|c|c|c|c|}
\hline $\begin{array}{c}\text { DEPOSIT- } \\
\text { Type- } \\
\text { Metal Suite }\end{array}$ & PHASE & CATEGORY & $\begin{array}{c}\text { TONS OF } \\
\text { RESOURCE }\end{array}$ & $\begin{array}{l}\mathrm{cu} \\
\%\end{array}$ & \begin{tabular}{c|}
$\mathrm{Cu}$ \\
thousand \\
pounds
\end{tabular} & \begin{tabular}{c|c}
$\mathrm{Pb}$ \\
$\%$
\end{tabular} & \begin{tabular}{|c|}
$\mathrm{Pb}$ \\
thousand \\
pounds
\end{tabular} & $\begin{array}{l}\mathrm{zn} \\
\%\end{array}$ & \begin{tabular}{c|c}
$\mathrm{Zn}$ \\
thousand \\
pounds
\end{tabular} & $\begin{array}{c}\mathrm{Au} \\
\mathrm{oz} / \mathrm{ton}\end{array}$ & \begin{tabular}{|c|} 
Au \\
thousand \\
ounces \\
\end{tabular} & $\begin{array}{c}\mathrm{Ag} \\
\mathrm{oz} / \text { ton }\end{array}$ & \begin{tabular}{c|}
$A g$ \\
thousand \\
ounces
\end{tabular} & $\begin{array}{l}\text { Mo } \\
\%\end{array}$ & \begin{tabular}{c|}
$\begin{array}{c}\text { Mo } \\
\text { thousand } \\
\text { pounds }\end{array}$ \\
\end{tabular} & $\begin{array}{c}\text { TREO+Y } \\
\%\end{array}$ & \begin{tabular}{|c|} 
TREO+Y \\
thousand \\
pounds \\
\end{tabular} & $\begin{array}{c}\text { Graphite } \\
\%\end{array}$ & $\begin{array}{c}\text { Graphite } \\
\text { thousand } \\
\text { Pounds }\end{array}$ \\
\hline \multicolumn{20}{|c|}{ BORNITE - Massive sulfide - Polymetallic (copper) } \\
\hline & Exploration (in pit, $0.5 \%$ cut-off) & Indicated & $15,500,000$ & 1.08 & 334,000 & & & & & & & & & & & & & & \\
\hline & Exploration (in pit, $0.5 \%$ cut-off) & Inferred & $120,800,000$ & 0.94 & $2,259,000$ & & & & & & & & & & & & & & \\
\hline & Exploration (below pit, $1.5 \%$ cut-off) & Inferred & $61,300,000$ & 2.81 & $3,437,000$ & & & & & & & & & & & & & & \\
\hline & & Total & $197,600,000$ & 1.53 & $6,030,000$ & & & & & & & & & & & & & & \\
\hline \multicolumn{20}{|c|}{ DELTA - Massive sulfide - Polymetallic (copper, lead, zinc, gold, silver) } \\
\hline & Exploration (DW/Mid/Nunatak/LP) & Inferred & $9,400,000$ & 0.4 & 75,200 & 1.75 & 329,000 & 4.61 & 866,680 & 0.047 & 441.9 & 1.85 & 17,402 & & & & & & \\
\hline & Exploration (PP2) & Inferred & $5,900,000$ & 0.4 & 47,200 & 2.1 & 247,800 & 4.6 & 542,800 & 0.050 & 292.9 & 2.07 & 12,232 & & & & & & \\
\hline & Exploration (DDS) & Inferred & $2,300,000$ & 1.1 & 50,600 & 2.6 & 119,600 & 6.5 & 299,000 & 0.070 & 161.2 & 2.98 & 6,850 & & & & & & \\
\hline & Exploration (DDN) & Inferred & $1,200,000$ & 1.6 & 38,400 & 2.4 & 57,600 & 2.3 & 55,200 & 0.093 & 112.1 & 2.98 & 3,574 & & & & & & \\
\hline & & Total & $18,800,000$ & 0.6 & 211,400 & 1.9] & 754,000 & 4.5 & $1,763,680$ & 0.048 & $1,008.1$ & 1.96 & 40,058 & & & & & & \\
\hline \multicolumn{20}{|c|}{ GREENS CREEK - Massive sulfide - Polymetallic (lead, zinc, gold, silver) } \\
\hline & Production & Proven & 4,700 & & & 3.7 & 360 & 9.2 & 880 & 0.100 & 0.5 & 15.7 & 74 & & & & & & \\
\hline & Production & Probable & $7,691,000$ & & & 3.1 & 481,340 & 8.3 & $1,279,860$ & 0.100 & 73.8 & 12.2 & 93,947 & & & & & & \\
\hline & Production & Measured & & & & & & & & & & & & & & & & & \\
\hline & Production & Indicated & 823,000 & & & 3.5 & 57,440 & 8.0 & 132,340 & 0.120 & 102.0 & 11.0 & 9,062 & & & & & & \\
\hline & Production & Inferred & $3,452,000$ & & & 2.8 & 194,360 & 6.6 & 458,480 & 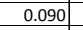 & 315.0 & 13.6 & 46,881 & & & & & & \\
\hline & & Total & $11,970,700$ & & & 3.04 & 733,500 & 7.8 & $1,871,560$ & 0.098 & 491.3 & 12.5 & 149,964 & & & & & & \\
\hline \multirow{2}{*}{\multicolumn{20}{|c|}{ LIK - Massive sulfide - Base metals (lead, zinc, silver) }} \\
\hline & Advanced Exploration (Lik South, in pit, 5\% Zn+Pb cut-off) & Indicated & $18,570,000$ & & & 2.70 & $1,003,000$ & 8.04 & $2,986,000$ & & & 1.463 & 27,170 & & & & & & \\
\hline & Advanced Exploration (Lik North, in pit, $5 \%$ Zn+Pb cut-off) & Indicated & 490,000 & & & 2.77 & 27,000 & 10.03 & 98,000 & & & 1.723 & 840 & & & & & & \\
\hline & Advanced Exploration (Lik South, other, $7 \%$ Zn+Pb cut-off) & Indicated & 760,000 & & & 3.15 & 48,000 & 8.04 & 122,000 & & & 1.489 & 1,130 & & & & & & \\
\hline & Advanced Exploration (Lik North, other, $7 \%$ Zn+Pb cut-off) & Indicated & 140,000 & & & 2.93 & 8,000 & 8.93 & 25,000 & & & 1.095 & 150 & & & & & & \\
\hline & Advanced Exploration (Lik South, in pit, $5 \% \mathrm{Zn}+\mathrm{Pb}$ cut-off) & Inferred & 820,000 & & & 1.94 & 32,000 & 7.73 & 127,000 & & & 0.391 & 320 & & & & & & \\
\hline & Advanced Exploration (Lik North, in pit, 5\% Zn+Pb cut-off) & Inferred & $2,350,000$ & & & 2.94 & 138,000 & 8.88 & 417,000 & & & 1.337 & 3,140 & & & & & & \\
\hline & Advanced Exploration (Lik South, other, $7 \% \mathrm{Zn}+\mathrm{Pb}$ cut-off) & Inferred & 560,000 & & & 1.59 & 18,000 & 6.97 & 78,000 & & & 0.330 & 180 & & & & & & \\
\hline & Advanced Exploration (Lik North, other, $7 \%$ Zn+Pb cut-off) & Inferred & $2,160,000$ & & & 2.99 & 129,000 & 9.22 & 398,000 & & & 1.337 & 2,890 & & & & & & \\
\hline & & Total & $25,850,000$ & & & 2.72 & $1,403,000$ & 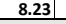 & $4,251,000$ & & & 1.163 & 30,060 & & & & & & \\
\hline NIBLACK - Me & issive sulfide - Polymmetallic (copper, zinc, gold, silver) & & & & & & & & & & & & & & & & & & \\
\hline & Advanced Exploration (Lookout deposit) & Indicated & $6,220,000$ & 0.95 & 118,180 & & & 1.73 & 215,212 & 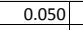 & 311.0 & 0.86 & 5,349 & & & & & & \\
\hline & Advanced Exploration (Lookout deposit) & Inferred & $2,610,000$ & 0.73 & 38,106 & & & 1.17 & 61,074 & 0.041 & 107.0 & 0.63 & 1,644 & & & & & & \\
\hline & Advanced Exploration (Trio deposit) & Inferred & $1,120,000$ & 1.00 & 22,400 & & & 1.56 & 34,944 & 0.032 & 35.8 & 0.48 & 538 & & & & & & \\
\hline & & Total & $9,955,000$ & 0.81 & 186,794 & & & 1.29 & 322,928 & 0.046 & 453.9 & 0.76 & 7,531 & & & & & & \\
\hline PALMER - Ma & ssive sulfide - Polymetallic (copper, lead, zinc, gold, silv & & & & & & & & & & & & & & & & & & \\
\hline & & IInferred & $5,236,000$ & 1.84 & 192,685 & 0.15 & 15,708 & 4.57] & 478,570 & 0.008 & 42.8 & 0.849 & 4,445 & & & & & & \\
\hline RED DOG - M & assive sulfide - Base metals (lead, zinc, silver) & & & & & & & & & & & & & & & & & & \\
\hline & Production (Aqqaluk, Qanaiyaq) & Proven and Probable & $58,200,000$ & & & 4.3 & $5,005,000$ & 16.5 & $19,206,000$ & & & 2.34 & 135,955 & & & & & & \\
\hline & Production (Qanaiyaq only) & Probable (included above) & $8,160,000$ & & & 6.9 & $1,132,000$ & 24.7 & $4,051,000$ & & & (n) & & & & & & & \\
\hline & Production (Aqqaluk, Qanaiyaq) & Indicated & & & & & & & & & & & 0 & & & & & & \\
\hline & Production (Aqqaluk, Qanaiyaq) & Inferred & 300,000 & & & 3.3 & 20,000 & 10.6 & 64,000 & & & 1.99 & 598 & & & & & & \\
\hline & & Total & $58,500,000$ & & & 4.3 : & $5,025,000$ & & $23,321,000$ & & & 2.33 & 136,554 & & & & & & \\
\hline SUN - Massiv & e sulfide - Polymetallic (copper, lead, zinc, gold, silver) & & & & & & & & & & & & & & & & & & \\
\hline & Exploration (Main deposit, \$75/tonne cut-off) & Indicated & $1,994,000$ & 1.53 & 60,843 & 1.07 & 50,585 & 4.30 & \begin{tabular}{|c|c|}
171,337 \\
\end{tabular} & 0.006 & 14.0 & 1.66 & 3,315 & & & & & & \\
\hline & Exploration (Main deposit, $\$ 75 /$ tonne cut-off) & Inferred & $10,842,000$ & 1.19 & 258,541 & 1.46 & 315,503 & 4.24 & \begin{tabular}{c|c|c|c|}
918,295 \\
\end{tabular} & 0.007 & 77.0 & 2.27 & 24,549 & & & & & & \\
\hline & Exploration (Southwest deposit, \$75/tonne cut-off) & Indicated & 392,000 & 0.86 & 6,777 & 1.03 & 8,057 & 3.15 & 24,761 & 0.006 & 2.0 & 1.77 & 693 & & & & & & \\
\hline & Exploration (Southwest deposit, $\$ 75 /$ tonne cut-off) & Inferred & $1,997,000$ & 1.14 & 292,671 & 0.9 & 35,745 & 2.17 & 86,652 & 0.006 & 13.0 & 2.12 & 4,227 & & & & & & \\
\hline & & Total & $13,231,000$ & 1.40 & 557,989 & 1.52 & 359,305 & 4.543 & $1,029,708$ & 0.008 & 92.0 & 2.48 & 29,469 & & & & & & \\
\hline PEBBLE - Por & hyry - Polymetallic (copper, gold, silver, molybdenum) & & & & & & & & & & & & & & & & & & \\
\hline & Advanced Exploration (0.3 CuEq cut-off) & Measured & $580,912,100$ & 0.33 & $3,830,000$ & & & & & 0.010 & $5,930.0$ & 0.0485 & 28,300 & 0.0178 & 210,000 & & & & \\
\hline & Advanced Exploration (0.3 CuEq cut-off) & Indicated & $6,516,797,600$ & 0.41 & $53,420,000$ & & & & & 0.010 & $64,620.0$ & 0.0485 & 315,500 & 0.0245 & $3,200,000$ & & & & \\
\hline & Advanced Exploration (0.3 CuEq cut-off) & Inferred & $4,916,258,000$ & 0.25 & $24,550,000$ & & & & & 0.008 & $37,325.0$ & 0.0347 & 170,490 & 0.0222 & $2,180,000$ & & & & \\
\hline & & Total & $12,013,967,700$ & 0.34 & $81,800,000$ & & & & & 0.009 & $107,875.0$ & 0.0429 & 514,290 & 0.023 & $5,750,000$ & & & & \\
\hline PYRAMID - Po & rphyry - Polymetallic (copper, gold, molybdenum) & & & & & & & & & & & & & & & & & & \\
\hline & Exploration (supergene) & Inferred & $103,616,200$ & 0.4 & $\mid 104,000$ | & & & & & 0.003 & 276.0 & & & 0.02 & 40,000 & & & & \\
\hline & Exploration (hypogene only, $0.21 \%$ CuEq cut-off) & Inferred & $87,081,700$ & 0.3 & 87,000 & & & & & 0.002 & 212.0 & & & 0.02 & 34,000 & & & & \\
\hline & & Total & $190,697,900$ & 0.4 & 191,000 & & & & & 0.003 & 488.0 & & & 0.02 & 74,000 & & & & \\
\hline TETLIN - Porp & hyry (skarn) - Polymetallic (copper, gold, silver) & & & & & & & & & & & & & & & & & & \\
\hline & Exploration (Peak Zone, $0.5 \mathrm{~g} /$ tonne Au cut-off) & Indicated & $6,580,000$ & 0.25 & 32,900 & & & & & 0.101 & 664.9 & 0.34 & 2,267 & & & & & & \\
\hline & Exploration (Peak Zone, $0.5 \mathrm{~g} /$ tonne Au cut-off) & Inferred & $4,240,000$ & 0.23 & 19,504 & & & & & 0.060 & 256.5 & 0.42 & 1,770 & & & & & & \\
\hline & & Total & $10,820,000$ & 0.24 & 52,404 & & & & & 0.085 & 921.4 & 0.37 & 4,037 & & & & & & \\
\hline WHISTLER - P & Polymetallic (Copper, gold, silver) & & & & & & & & & & & & & & & & & & \\
\hline & Exploration & Indicated & $87,300,000$ & 0.17 & 302,000 & & & & & 0.015 & $1,280.0$ & 0.058 & 5,030 & & & & & & \\
\hline & Exploration & Inferred & $160,700,000$ & 0.15 & $\mid 467,000$ & & & & & 0.012 & $1,850.0$ & 0.051 & 8,210 & & & & & & \\
\hline & & Total & $248,000,000$ & 0.16 & 769,000 & & & & & 0.013 & $3,130.0$ & 0.053 & $\frac{13,240}{132}$ & & & & & & \\
\hline BOKAN MOUN & TAIN - Other $(\operatorname{In}$ & ents) & & & & & & & & & & & & & & & & & \\
\hline & Advanced Exploration (Dotson trend, $0.4 \%$ & Indicated & $3,200,000$ & & & & & & & & & & & & & 0.6 & 39,7322 & & \\
\hline & Advanced Exploration (Dotson trend, $0.4 \%$ TREO cut-off) & Inferred & $2,200,000$ & & & & & & & & & & & & & 0.66 & 26,60 & & \\
\hline & 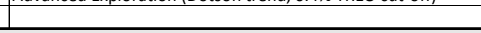 & Total & $5,400,000$ & & & & & & & & & & & & & 0.614 & & & \\
\hline GRAPHITE CRE & EK - Other - Other (graphite) & & & & & & & & & & & & & & & & & & \\
\hline & Exploration (3.0\% cg cut-off) & Inferred & $205,980,000$ & & & & & & & & & & & & & & & & 22,808 \\
\hline
\end{tabular}


1 Lisburne district

Noatak district

Wainwright district

Barrow district

Colville district

Canning district

Sheenjek district

Chandalar district

Koyukuk district

10 Shungnak district

11 Kiana \& Selawik districts

12 Fairhaven district (Candle subdistrict)

13 Fairhaven district (Inmachuk subdistrict)

14 Serpentine district

15 Port Clarence district

16 Kougarok district

17 Nome (Cape Nome) district

18 Council district

19 Koyuk district

20 Hughes district

21 Kaiyuh district

22 Anvik district $^{\mathrm{b}}$

23 Marshall district

24 Bethel district

25 Goodnews Bay district

26 Aniak district

27 Iditarod district

28 McGrath district

29 Innoko district

30 Ruby district

31 Kantishna district

32 Hot Springs district

33 Melozitna district

34 Rampart district

35 Tolovana district

36 Yukon Flats district

37 Circle district

38 Black district

39 Eagle district

40 Fortymile district

41 Chisana district

42 Tok district

43 Goodpaster district

44 Fairbanks district

45 Bonnifield district

46 Richardson subdistrict of Fairbanks district ${ }^{c}$

47 Delta River district

48 Chistochina district

49 Valdez Creek district

50 Yentna district

51 Redoubt district

52 Bristol Bay Region

53 Kodiak district (53b)-Alaska Peninsula Region (53a)

54 Homer district

55 Hope \& Seward districts

56 Anchorage district $^{d}$

57 Willow Creek district

58 Prince William Sound district

59 Nelchina district

60 Nizina district

61 Yakataga district

62 Yakutat district $^{\mathrm{e}}$

63 Juneau district (partial)

64 Juneau (64a) \& Admiralty (64b) districts

65 Chichagof district

66 Petersburg district

67 Kupreanof district

68 Hyder district

69 Ketchikan district

70 Bering Sea Region

71 Aleutian Islands Region

Unknown (undistributed) ${ }^{\dagger}$

TOTAL (refined Troy ounces)
0
800

7,800

0

0

0

70,278

378,075

15,000

40,607

254,265

349,975

4,536

42,358

191,712

$5,043,465$

$1,047,042$

84,462

403,671

149,703

124,506

42,953

31,202

613,407

$1,565,226$

364,672

757,219

478,023

99,307

604,926

14,630

204,845

547,556

$1,125,341$

2
52,166

602,758

144,521

288

$2,817,130$

$15,003,124$

108,983

121,749

11,736

186,604

533,167

204,980

105

1,570

112,409

17

135,252

460

667,841

137,802

15,016

148,500

18,041

13,200

82,540

$9,718,971$

770,000

15,000

219

62,002

0

29

$46,342,950$

(1,441 tonnes)

\begin{tabular}{|c|c|}
\hline 0 & 0 \\
\hline 7,800 & 0 \\
\hline 0 & 0 \\
\hline 0 & 0 \\
\hline 0 & 0 \\
\hline 0 & 0 \\
\hline 0 & 0 \\
\hline 52,878 & 17,400 \\
\hline 378,075 & 0 \\
\hline 15,000 & 0 \\
\hline 40,607 & 0 \\
\hline 254,265 & 0 \\
\hline 349,975 & 0 \\
\hline 4,536 & 0 \\
\hline 42,358 & 0 \\
\hline 191,712 & 0 \\
\hline $5,043,465$ & 0 \\
\hline $1,020,042$ & 27,000 \\
\hline 84,462 & 0 \\
\hline 403,671 & 0 \\
\hline 5,400 & 144,303 \\
\hline 7 & 0 \\
\hline 124,506 & 0 \\
\hline 42,953 & 0 \\
\hline 31,202 & 0 \\
\hline 613,407 & 0 \\
\hline $1,562,296$ & 2,930 \\
\hline 133,307 & 231,365 \\
\hline 757,063 & 156 \\
\hline 478,023 & 0 \\
\hline 91,401 & 7,906 \\
\hline 604,926 & 0 \\
\hline 14,630 & 0 \\
\hline 204,845 & 0 \\
\hline 547,556 & 0 \\
\hline 0 & 0 \\
\hline $1,125,341$ & 0 \\
\hline 2 & 0 \\
\hline 52,166 & 0 \\
\hline 602,758 & 0 \\
\hline 78,021 & 66,500 \\
\hline 288 & 0 \\
\hline 2,051 & $2,815,079$ \\
\hline $8,282,670$ & $6,720,454$ \\
\hline 102,283 & 6,700 \\
\hline 119,449 & 2,300 \\
\hline 11,736 & 0 \\
\hline 186,604 & 0 \\
\hline 531,586 & 1,581 \\
\hline 204,980 & 0 \\
\hline 105 & 0 \\
\hline 1,570 & 0 \\
\hline 4,809 & 107,600 \\
\hline 17 & 0 \\
\hline 70,252 & 65,000 \\
\hline 460 & 0 \\
\hline 58,841 & 609,000 \\
\hline 102 & 137,700 \\
\hline 15,016 & 0 \\
\hline 148,500 & 0 \\
\hline 18,041 & 0 \\
\hline 2,200 & 11,000 \\
\hline 82,540 & 0 \\
\hline 82,390 & $9,636,581$ \\
\hline 0 & 770,000 \\
\hline 15,000 & 0 \\
\hline 0 & 0 \\
\hline 219 & 0 \\
\hline 4,002 & 58,000 \\
\hline 0 & 0 \\
\hline 0 & 0 \\
\hline 29 & 0 \\
\hline $24,904,395$ & $21,438,555$ \\
\hline
\end{tabular}




\section{Total gold production in Alaska by mining district, 1880-2014}

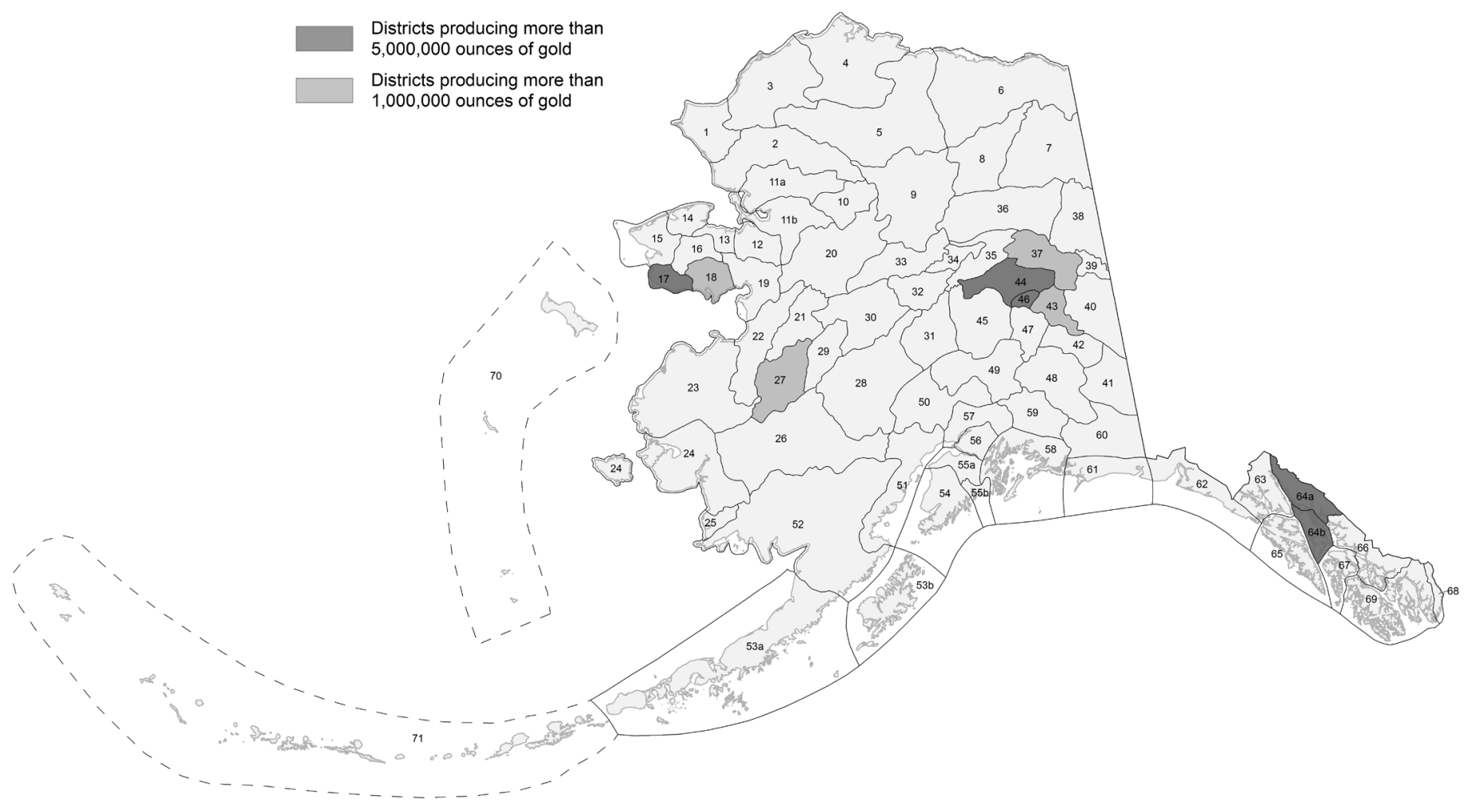

aMining district names and boundaries revised slightly from those defined by Ransome and Kerns (1954) and Cobb (1973). Sources of data: U.S. Geological Survey, U.S. Bureau of Mines, and Alaska Territorial Department of Mines records 1880-1930; U.S. Mint records 1930-1969; State of Alaska production records 1970-2014. Entries of "0" generally mean no specific records are available.

b Included in Marshall district.

${ }^{\mathrm{c}}$ Not included in total for Fairbanks district.

${ }^{\mathrm{d}}$ Most placer gold production included in Willow Creek district.

eIncludes lode production from Glacier Bay area and placer production from Lituya Bay area.

${ }^{f}$ Production that cannot be credited to individual districts due to lack of specific records or for reasons of confidentiality. 


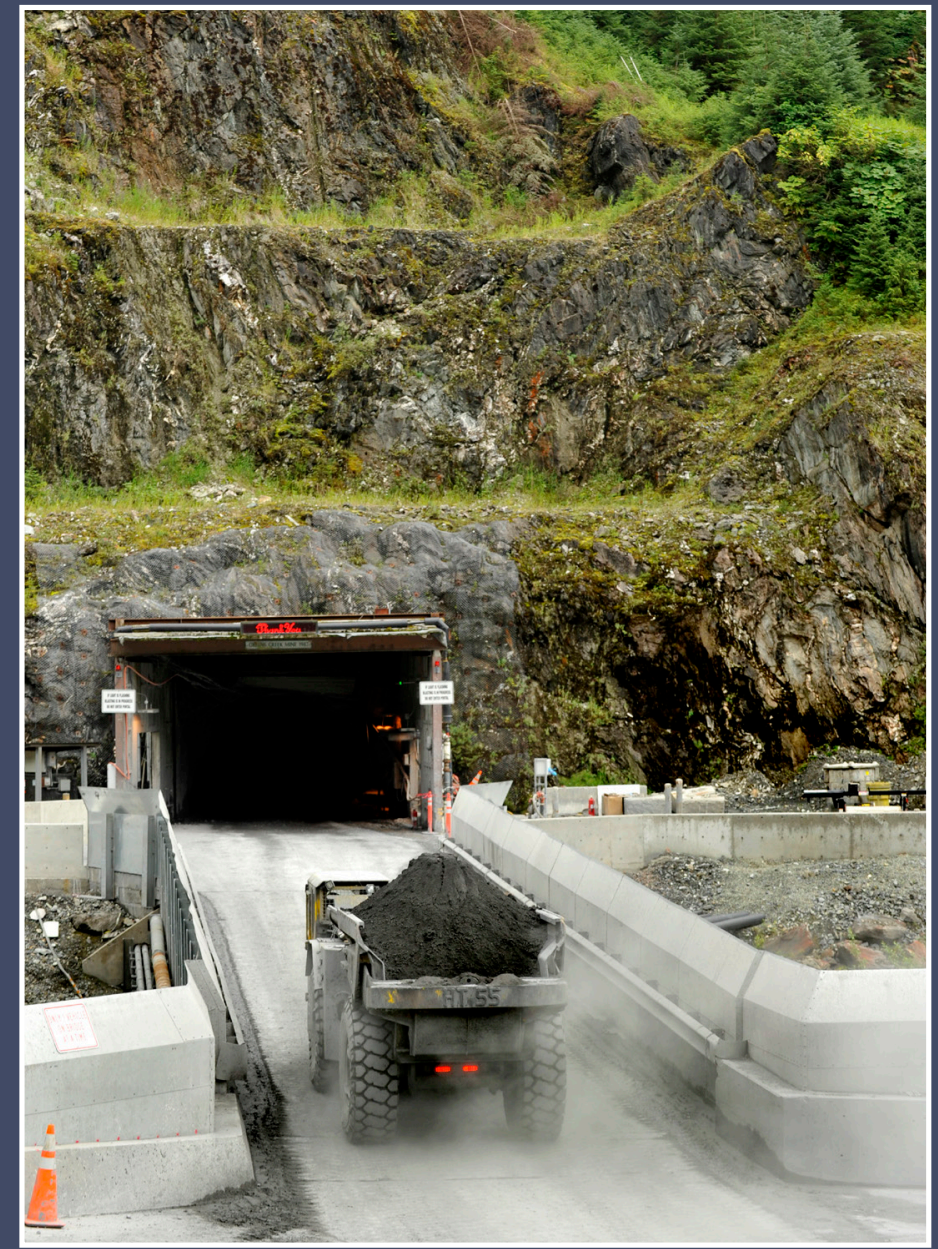

$4-1$
0
0
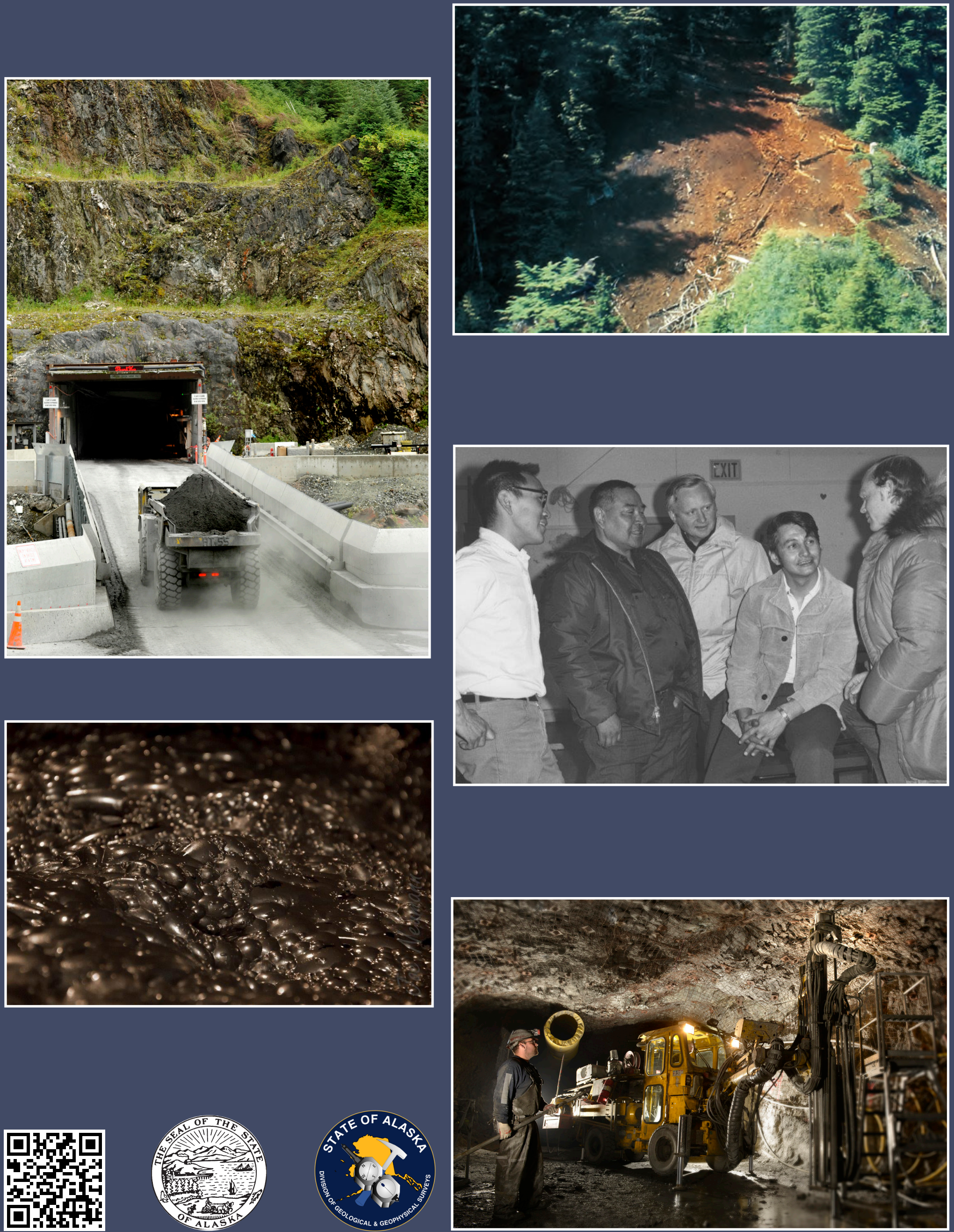